Revista de

Estudios

Kantianos

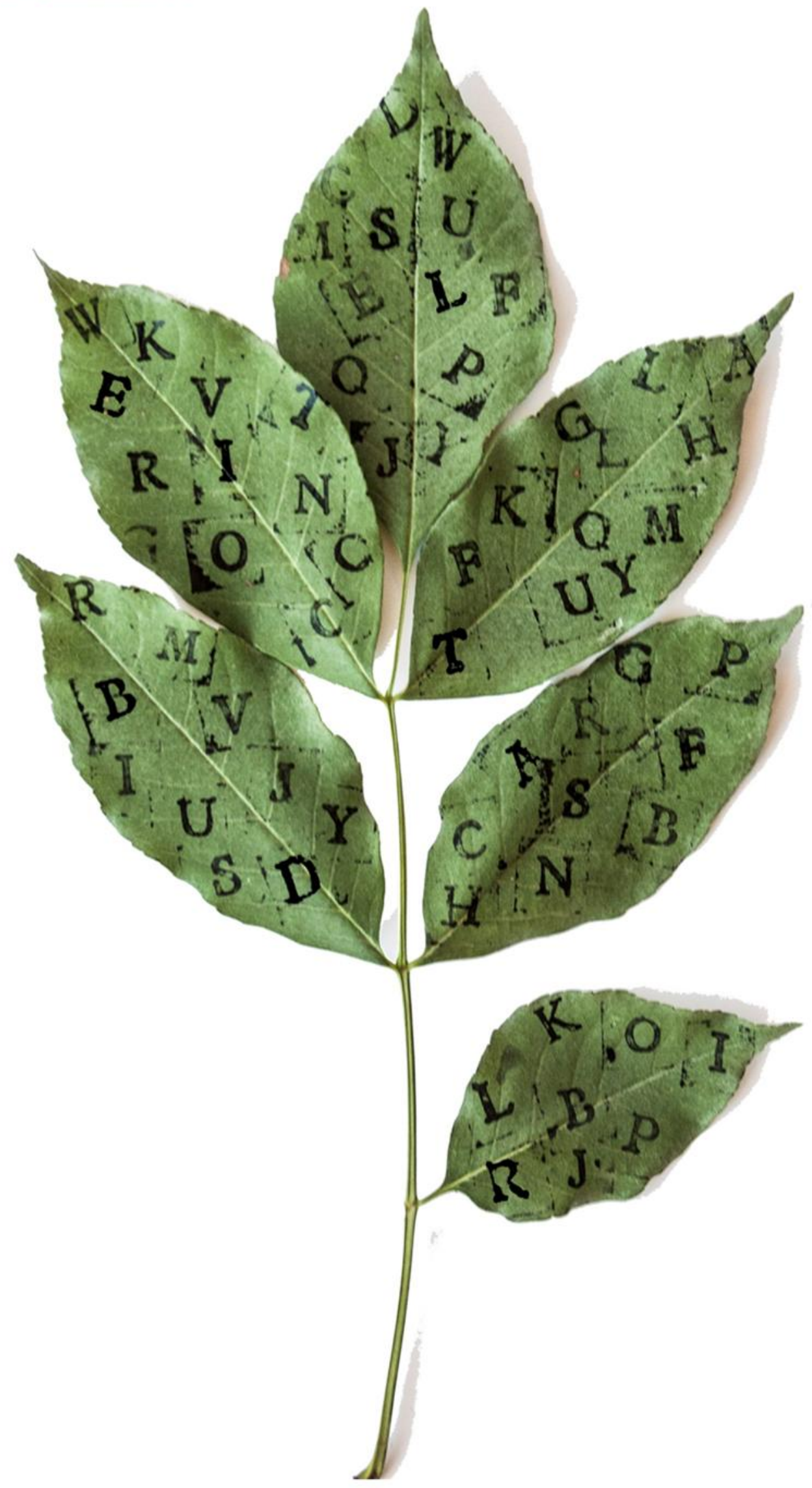




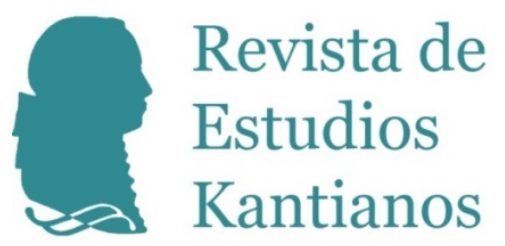




\section{Revista de Estudios Kantianos}

Publicación internacional de la Sociedad de Estudios Kantianos en Lengua Española Internationale Zeitschrift der Gesellschaft für Kant-Studien in Spanischer Sprache

International Journal of the Society of Kantian Studies in the Spanish Language

\section{Dirección}

Fernando Moledo, FernUniversität in Hagen

fernando.moledo@fernuni-hagen.de

Hernán Pringe, CONICET-Universidad de Buenos Aires/

Universidad Diego Portales, Santiago de Chile

hpringe@gmail.com

\section{Secretario de edición}

Óscar Cubo Ugarte, Universitat de València

oscar.cubo@uv.es

\section{Secretaria de calidad}

Alba Jiménez Rodríguez, Universidad Complutense de Madrid

albjim04@ucm.es

\section{Editores científicos}

Jacinto Rivera de Rosales, UNED, Madrid

Claudia Jáuregui, Universidad de Buenos Aires

Vicente Durán, Pontificia Universidad Javeriana, Bogotá

Julio del Valle, Pontificia Universidad Católica del Perú, Lima

Jesús Conill, Universitat de València

Gustavo Leyva, Universidad Autónoma de México, México D. F.

María Xesús Vázquez Lobeiras, Universidade de Santiago de Compostela

Wilson Herrera, Universidad del Rosario, Bogotá

Pablo Oyarzun, Universidad de Chile, Santiago de Chile

Paula Órdenes Azúa, Universität Heidelberg 


\section{Comité científico}

Juan Arana, Universidad de Sevilla

Reinhardt Brandt, Philipps-Universität Marburg

Mario Caimi, Universidad de Buenos Aires

Monique Castillo, Université de Paris-Est

Adela Cortina, Universitat de València

Bernd Dörflinger, Universität Trier

Norbert Fischer, Universität Eichstätt-Ingolstadt

Miguel Giusti, Pontificia Universidad Católica del Perú

Dulce María Granja, Universidad Nacional Autónoma de México

Christian Hamm, Universidad Federal de Santa María, Brasil

Dietmar Heidemann, Université du Luxembourg

Otfried Höffe, Universität Tübingen

Claudio La Rocca, Università degli Studi di Genova

Juan Manuel Navarro Cordón, Universidad Complutense, Madrid

Carlos Pereda, Universidad Nacional Autónoma de México

Gustavo Pereira, Universidad de la República, Uruguay

Ubirajara Rancan de Azevedo, Universidade Estadual Paulista, Brasil

Margit Ruffing, Johannes Gutenberg-Universität Mainz

Gustavo Sarmiento, Universidad Simón Bolívar, Venezuela

Sergio Sevilla, Universitat de València

Roberto Torretti, Universidad Diego Portales, Santiago de Chile

Violetta Waibel, Universität Wien

Howard Williams, University of Aberystwyth

Allen W. Wood, Indiana University

Diseño, revisión de estilo, corrector y maqueta

Josefa Ros Velasco, Harvard University, Cambridge (MA)

\section{Entidades colaboradoras}

Sociedad de Estudios Kantianos en Lengua Española (SEKLE)

Departament de Filosofia de la Universitat de València

Instituto de Humanidades, Universidad Diego Portales

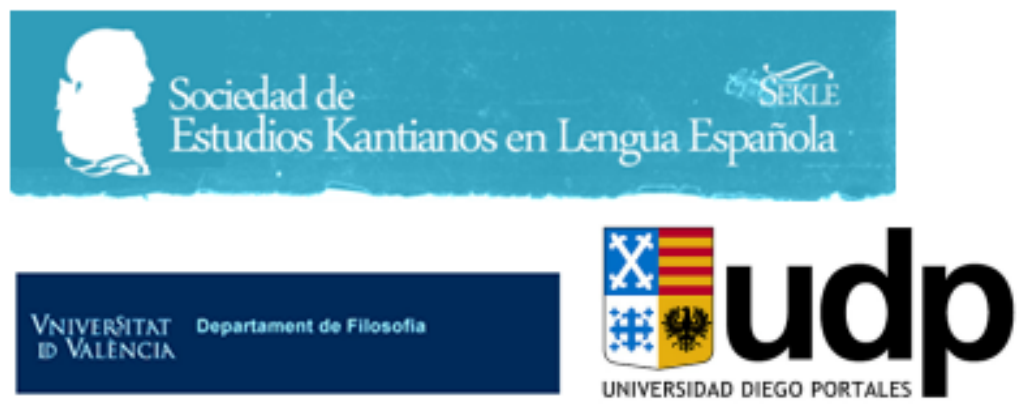




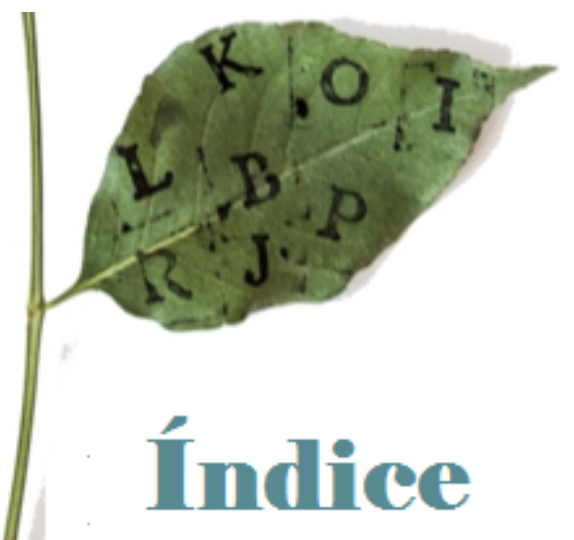

\section{Artículos}

1 El concepto teórico de libertad según Kant y la tradición de la libertas spontaneitatis

Thomas Sören Hoffmann

DOI 10.7203/REK.4.1.14849

21 From the unity of sensible intuition to the sensible unity of intuition. Revisiting the proof-structure of Kant's B-Deduction argument Adriano Perin

DOI: $10.7203 /$ REK.4.1.12644

44 The Principle of the Transcendental Deduction. The First Section of the Deduction of the Pure Concepts of the Understanding Rudolf Meer DOI: 10.7203/REK.4.1.14339

63 ¿Por qué son — según Kant- imposibles las hipótesis en matemática?

Reyna Fortes

DOI: 10.7203/REK.4.1.12777 
90 El reino de los fines y la comunidad ética. Acerca de la dimensión intersubjetiva de la ética kantiana

Ileana Beade

DOI: 10.7203/REK.4.1.12775

\section{Recensiones}

113 Mario Caimi: Kant's B Deduction. Newcastle upon Tyne, Cambridge Scholars Publishing, 2014, 140 pp. ISBN (13): 978-1-4438-6537-1

Paola Rumore

DOI: 10.7203/REK.4.1.14280

121 Gustavo Leyva, Álvaro Peláez y Pedro Stepanenko (Eds.): Los rostros de la razón: Immanuel Kant desde Hispanoamérica (3 volúmenes). México, UAM-Cuajimalpa/Anthropos, 2018, 727 pp. ISBN (UAM): 978-607-28-1348-9/ISBN (Anthropos): 978-8416421-91-6

Francisco Javier Iracheta Fernández DOI: 10.7203/REK.4.1.14135

134 Ileana Beade: La libertad y el orden en la filosofía jurídica kantiana. Rosario, Fhumyar Ediciones, 2017, 310 pp. ISBN: 978-987-3638-169

Marilín Gómez

DOI: 10.7203/REK.4.1.14266

138 Christian Krijnen (Ed.): Metaphysics of Freedom? Kant's Concept of Cosmological Freedom in Historical and Systematic Perspective.

Leiden/Boston, Brill (Critical Studies in German Idealism, vol. 23), 2018, 221 pp. ISBN: 978-90-40-38377-7

Jacinto Páez

DOI: $10.7203 /$ REK.4.1.14337 


\section{Traducción}

145 Salomon Maimon frente a la filosofía trascendental. Traducción de algunas cartas sobre su filosofía teórica

David Hereza Modrego

DOI: 10.7203/REK.4.1.13956

\section{Informes}

173 Informe del IV Congreso Internacional de la SEKLE Alejandra Baher

Luciana Martínez

DOI: 10.7203/REK.4.1.14281

178 Ata do Simpósio Internacional de Kant a Hegel

Agemir Bavaresco

Jair Tauchen

Evandro Pontel

DOI: 10.7203/REK.4.1.14269

\section{Eventos y normas para autores}

185 Normas para autores 


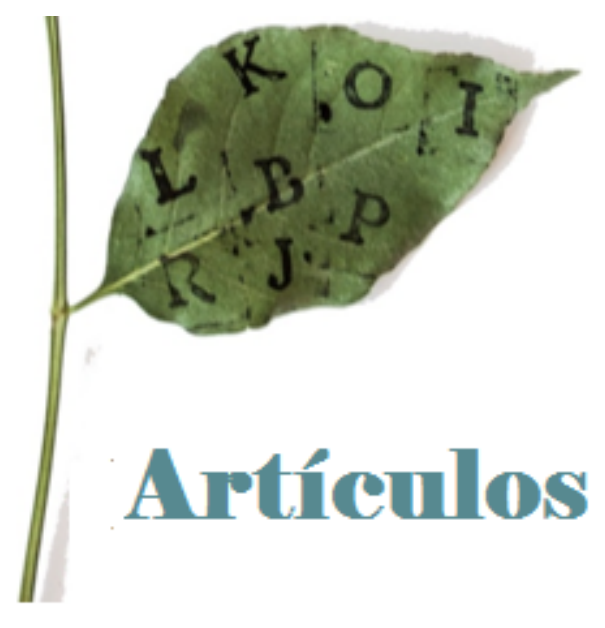




\title{
El concepto teórico de libertad según Kant y la tradición de la libertas spontaneitatis ${ }^{1}$
}

\author{
THOMAS SÖREN HOFFMANN ${ }^{2}$
}

\begin{abstract}
Resumen
El artículo reconstruye el camino de Kant hacia una comprensión trascendental, esto es, tal como lo enseña la filosofía crítica, hacia una comprensión genuinamente reflexiva de la libertad. Para ello, en primer lugar, se recordará aquí la alternativa entre "libertas indifferentiae" y "libertas spontaneitatis"; una alternativa propia de la modernidad temprana, que adquiere su significado, no en menor medida, en el marco de la crisis de la ontología (teleológica) aristotélica. En este contexto, Leibniz entiende la "libertad" como auto-realización fundada en la sustancia individual. Kant, en la Nova Dilucidatio, sigue la posición de Leibniz, aunque lo hace con reparos. Pero en la $\mathrm{KrV}$ se comprueba ya que cualquier clase de fundamentación ontológico-objetiva de la libertad resulta problemática. La tercera antinomia puede leerse, en ese sentido, como una crítica a Leibniz. La comprensión "trascendental" alternativa de una libertad fundamentalmente no objetivable —una comprensión que al mismo tiempo remite a la absoluta espontaneidad de la relación reflexiva con sí mismo - describe la condición de posibilidad de la libertad propiamente práctica que, a su vez, puede ser entendida como una manera de auto-realización de la idea de libertad.
\end{abstract}

Palabras clave: liberum arbitrium, espontaneidad, libertad trascendental, ontología

\section{Kants theoretischer Freiheitsbegriff und die Tratidion der libertas spontaneitatis}

\section{Zusammenfassung}

Der Beitrag rekonstruiert Kants Weg zu einem transzendentalen, d.h. genuin reflexiven Verständnis von Freiheit, wie es mit Kants kritischer Philosophie vorliegt. Dabei wird zunächst an die frühneuzeitliche Alternative von „libertas indifferentiae“ und „libertas spontaneitatis“ erinnert, deren Sinn sich nicht zuletzt vor dem Hintergrund der Krise der aristotelischen (teleologischen) Ontologie ergibt; Leibniz hat in dieser Situation „Freiheit“ als in der individuellen Substanz

\footnotetext{
${ }^{1}$ Traducción de Mario Caimi y Fernndo Moledo. Una versión previa de este artículo se encuentra publicada como: Thomas Sören Hoffmann: „Kants theoretischer Freiheitsbegriff und die Tradition der ,libertas spontaneitatis““. En: Christian Krijnen (ed.), Metaphysics of Freedom? Kant's Concept of Cosmological Freedom in Historical and Systematic Perspective, Leiden/Boston, Brill, 2018, 47-67.

${ }^{2}$ FernUniversität in Hagen. Contacto: thomas.hoffmann@,fernuni-hagen.de.
} 
begründeten Selbstvollzug verstanden. In der „Nova dilucidatio“ ist Kant mit einigen Einschränkungen noch dem Leibnizschen Ansatz gefolgt, während er in der $\mathrm{KdrV}$ jede Art einer objektivistisch-ontologischen Fundierung von Freiheit als problematisch erweist; die dritte Antinomie kann insoweit auch als eine Leibnizkritik gelesen werden. Das alternative „transzendentale“ Verständnis einer grundsätzlich nicht verobjektivierbaren Freiheit, das zugleich auf die absolute Spontaneität des reflexiven Selbstverhältnisses verweist, beschreibt dabei ebenso die Bedingung der Möglichkeit eigentlich praktischer Freiheit, die ihrerseits wieder als Weise der Selbstrealisierung der Idee der Freiheit verstanden werden kann.

Stichwörter: liberum arbitrium, Spontaneität, transzendentale Freiheit, Ontologie

En un conocido pasaje de la Crítica de la facultad de juzgar, Kant dice que "de las tres ideas puras de la razón, Dios, Libertad e Inmortalidad, la de la libertad es el único concepto de lo suprasensible que demuestra su realidad objetiva [...] en la naturaleza por medio de su posible influencia causal sobre ella" ( $K U$, AA 5: 474; v.t. $K U$, AA 5: 468). Más todavía: al ser la libertad la única idea de la razón que se da a sí misma realidad objetiva, ella es precisamente también el concepto mediador a través del cual las otras ideas que la acompañan alcanzan una "conexión con la naturaleza", de modo que en ella tenemos una "idea de lo suprasensible" con la cual, de cierta manera, trascendemos el concepto "teórico" de naturaleza sin tener que pasarlo simplemente por alto o ponerlo entre paréntesis ( $K U$, AA V, 474). En este contexto, Kant menciona también que la idea de la libertad, por medio de su auto-realización, así como también por medio de la realización mediata de las otras dos ideas de la razón, condicionada por la autorrealización de la idea de la libertad, "hace posible la conexión [...] de las tres [...] para una religión" $(K U, \mathrm{AA} \mathrm{V}, 474) .{ }^{3}$ En el contexto de la Crítica de la facultad de juzgar, el concepto de libertad alcanza así una efectiva función de bisagra entre el mundo sensible y el inteligible; función que posee en la culminación del desarrollo del pensamiento de Kant y que permite entender, con fundamento, toda la filosofía kantiana - tanto la teórica como la práctica - como mensura del alcance que tiene la idea de libertad. El concepto de libertad viene a ser,

\footnotetext{
${ }^{3}$ No profundizaremos este punto aquí, pero sostenemos que también la revolución del modo de pensar referida a la religión, que está presente en la filosofía de Kant y se lleva a cabo en ella de varias maneras, está fundada en el recurso a la libertad, como a un concepto fundamental de la religión.
} 
pues, el único terminus medius real entre el mundo sensible y el mundo inteligible.

En este trabajo estudiaremos el camino que Kant recorre en dirección a un concepto transcendental de libertad. Lo haremos tratando de poner ese camino en relación con la concepción de libertad que ha dominado los debates de la modernidad europea, incluso hasta la época en la que vivió Kant; esto es, con la concepción que entiende la libertad todavía a la manera de un objeto, por medio del concepto de libertas spontaneitatis. Es precisamente al final del camino correspondiente a esta concepción de la libertad cuando irrumpe el impulso kantiano, dirigido hacia una concepción de la libertad en la que ésta ya no es entendida como un objeto. En la primera parte comenzaremos por hacernos presente la constelación inicial de ideas dentro de la cual se plantea la argumentación de Kant. Esta constelación se caracteriza por la oposición de distintas concepciones de la libertad que, a pesar de tener antiguos precedentes, en el contexto de la ontología postaristotélica, deben pensarse de un modo renovado. Encontraremos aquí que el concepto de espontaneidad se plantea en el siglo XVII, de manera significativa, como un intento dirigido a poder pensar la libertad como algo que se encuentra en el mundo de las cosas. En la segunda parte veremos que Kant, en la fase pre-crítica de su obra, se muestra como defensor de la libertas spontaneitatis; y eso, incluso, cuando atendiendo a las discusiones de sus contemporáneos acerca del principio de razón suficiente o de razón determinante, expresa, no obstante, algunos problemas relativos a esa concepción, que entiende la libertad todavía como una cosa. En la tercera parte veremos que Kant, precisamente teniendo en cuenta esos problemas, mostrará, en la Crítica de la razón pura, que el concepto de libertas spontaneitatis es antinómico y que esa antinomia exige una nueva formulación del concepto de libertad, de acuerdo con la cual ella es entendida como una cosa. Para esta nueva formulación, Kant empleará el concepto por él introducido - de 'espontaneidad absoluta' y con el cual alcanzará el nivel de la 'libertad trascendental'. Finalmente, en la última parte, habrá que explicar con exactitud qué significa 'libertad trascendental' y cómo tiene lugar exactamente su referencia a su objeto, o en qué consiste su dimensión práctica. 


\section{La constelación de la libertas spontaneitatis}

La discusión de la modernidad temprana acerca de la libertad está determinada por varios factores epocales. Para nuestros fines, será suficiente considerar por separado tres de ellos: (i) en primer lugar, el retroceso, o la completa desaparición, de la ontología aristotélica; (ii) en segundo lugar, la correspondiente aparición del neo-estoicismo; (iii) en tercer término, la presencia del voluntarismo, introducido de diversas maneras gracias a los nuevos escenarios ontológicos.

(i) En primer lugar, respecto de la ontología aristotélica, cabe decir que su eliminación se debe a diversos motivos. Como es sabido, no es el menos significativo de ellos el éxito de la nueva ciencia galileana, para la cual, junto a la cuantificación sistemática, es constitutiva la supresión de la diferencia fundamental entre determinaciones substanciales y determinaciones accidentales. Esta supresión tiene consecuencias inmediatas respecto de la cuestión de la libertad, a la cual no son afines otras ontologías, como por ejemplo la cartesiana. La afinidad, en cambio, de la ontología aristotélica respecto de la libertad, y el problema que el abandono de esa ontología implica en relación con la concepción de la libertad, se puede comprobar fácilmente, por ejemplo, a la luz del concepto aristotélico de entelequia, o bien de la función de la causa finalis que está en relación con el concepto de entelequia; pues ambos conceptos hacen posible que la elección

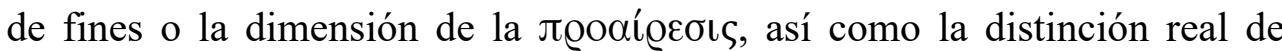

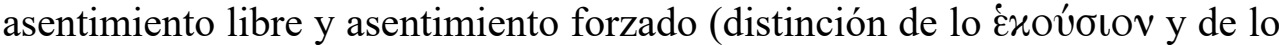
àxov́oเov), se remitan a un obrar fundado ontológicamente, en vez de tener que limitarse a reflejar un 'como si', a saber, el 'como si' de la percepción que el agente tiene de sí mismo.

La importancia que debió tener para la filosofía práctica la eliminación de la fundamentación aristotélica se puede apreciar en el hecho de que el problema de la teodicea de Leibniz se presente, en realidad, primero, para una ontología no aristotélica, en la cual el bien, que gana el carácter de un concepto-función, debe ser reintroducido gracias a un cálculo infinitesimal, por medio de una interrelación total de todos los entes. En correspondencia con esto se plantean ahora cuestiones como la del fundamento de la elección de los fines, pues la instauración de fines ya no puede ser entendida según la lógica de un perfeccionamiento natural de sí mismo. Dicho brevemente: en el mundo post-aristotélico, a la libertad le falta, 
por así decirlo, el substrato; le falta el cuerpo que ella debe animar y eso hace que fácilmente se la niegue, o bien, que se la conciba mediante la abstracción del liberum arbitrium.

(ii) En segundo lugar, respecto del Neoestoicismo, conviene, en nuestro contexto, señalar la restauración del determinismo que lo acompaña. Este se plasmó tanto en las disputas confesionales contemporáneas a la Reforma, como en la filosofía de la naturaleza, según es posible constatarlo

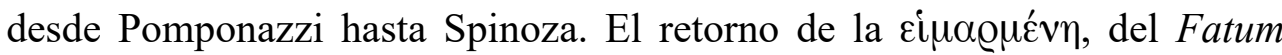
estoico, está aquí acompañado, por lo general, por una tesis de la racionalidad del ordo rerum que no está orientada simplemente hacia el pasado. La imaginación determinista permitió, en todo caso, representarse la totalidad de los fenómenos como un conjunto complejo de interacciones racionales de causas y efectos que se presenta en un espacio unitario, homogéneo, en el cual todo es siempre una función de otra cosa, de modo que la libertad, y con ella el originario ser en sí mismo y el permanecer en sí mismo, ya no tienen más cabida. Consiguientemente, la libertad se aparta del mundo de los objetos y se recluye en una actitud mental que consiste en poder decir que sí a las cosas, tal como ellas verdaderamente son, y que con ello evita las pérdidas y fricciones que de manera ineludible se presentan cuando el ordo idearum diverge del ordo rerum. El apaciguamiento de la mente, ante la aparente pérdida que esto podría representar, se logra por medio de la tesis de que así se gana en racionalidad. Pero, este apaciguamiento implica, por cierto, también una exigencia para el sujeto que ha de comprenderse a sí mismo, en último término, como una cosa más.

(iii) Finalmente, por lo que toca al Voluntarismo, cabe decir que éste no ofrece, por cierto, en el contexto de la modernidad, ninguna alternativa inmediata a la comprensión ontológica o cósica que el sujeto tiene de sí mismo. Pero al recurrir a una hipóstasis de la voluntad, el voluntarismo hace posible que el sujeto se instale en un segundo nivel ontológico, en el cual la libertad de la voluntad encuentra incluso su lugar originario. Un ejemplo de esto es el caso de Descartes y, mutatis mutandis, el que se presenta de nuevo, en la época de Kant, con Christian August Crusius, a quien nos referiremos brevemente más adelante. Los voluntaristas entienden la libertad, en lo esencial, a partir del liberum arbitrium y la conciben, con respecto a su contenido, como libertas indifferentiae, la cual, en el tiempo siguiente, será rival de la libertas spontaneitatis, que constituye a su vez especialmente el 
concepto de libertad de la Schulphilosophie leibniziano-wolffiana. La armonización con el ordo rerum de esta manera de entender la libertad será también, en cierto modo, el tema tratado en la tercera antinomia de la Crítica de la razón pura.

Resumamos, ahora, las coordenadas fundamentales de la libertas spontaneitatis que se inscribe en el contexto descrito. La libertas spontaneitatis es, en primer lugar, una concepción de libertad que tiene en cuenta el final de la ontología aristotélica, en la medida en que no está concebida de manera teleológica. En 'spontaneitas', los autores del siglo XVII ven, más que el aristotélico Ėxov́øıv, el igualmente aristotélico

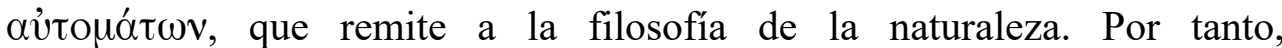
'spontaneitas' remite aquí, ante todo, a una actividad que no se limita al ser humano que obra de manera consciente. ${ }^{4}$ Además, puede referírsela también a un hecho de la naturaleza. En ese sentido, Hobbes, por ejemplo, puede escribir: "By spontaneity is meant inconsiderate action" (1840: 275). Y Glocenius puede afirmar, en su conocido Diccionario, que lo espontáneo se puede predicar de cosas que carecen de alma: "spontaneum [...] etiam rebus animo carentibus" [dicitur] y que, por consiguiente, es un término de mayor extensión que "voluntarium" (1613; 1964: art. 'sponte', 1080). Incluso en autores posteriores, como por ejemplo Tetens (1777) y también Fichte (1798), es posible encontrar el término 'espontaneidad' empleado también para designar la actividad mecánica (por ejemplo, la actividad propia de un resorte de acero).

En segundo lugar, la espontaneidad, como un concepto básico de libertad, es compatible con un determinismo de las series de acontecimientos externos. Eso se debe a que esta concepción permite considerar espontánea la actividad de, por ejemplo, el resorte de acero que salta (o bien —en un nivel superior - la libertad de una acción voluntaria), en el sentido de Ėxov́oıov o

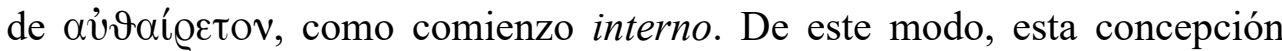
distingue esa actividad de una concatenación externa de fenómenos. Se trata aquí, ante todo, de un cambio de perspectivas que no puede ser efectuado de manera arbitraria, sino que está fundado en una dignidad ontológica: la de la oposición de lo 'interno' y lo 'externo'. Esa oposición tiene una dignidad tal

\footnotetext{
${ }^{4}$ Para la historia conceptual de 'Espontaneidad' [Spontaneität], en general, v. Hoffmann (1995). Para la diferenciación entre libertas indifferentiae y libertas spontaneitatis en relación, también, con Kant, v. Finster (1982; 1984) y Kawamura (1996).
} 
sobre todo para Leibniz, quien no por casualidad llega a ser el representante más importante de la concepción de una libertas spontaneitatis. 'Espontaneidad' significa, entonces, una conexión causal no lineal, por la cual la referencia retrospectiva a una actividad propia, interna, de los agentes se unifica con la posibilidad de coordinación de sus acciones en el aspecto externo. Aquí notamos — cabe señalar - que una de las diferencias decisivas entre la solución leibniziana del problema de la libertad y la antinomia kantiana consiste en que Leibniz entiende de manera metafísica las series de causas y efectos como coordinaciones que forman un sistema, mientras que Kant las entiende como determinaciones lineales. Está claro que, según la primera versión, la libertad, como espontaneidad individual, es compatible con el principio de razón suficiente, mientras que según la segunda versión eso ya no es posible.

En tercer lugar, el concepto de una 'libertas spontaneitatis' permite pensar la libertad como un principio real activo; es decir, permite que no haya que reducirla a una libertas indifferentiae. De ello resulta que la espontaneidad puede ser concebida como determinada a partir de la individualidad, del 'ser sí mismo' del agente operante en cada caso. Y así también, la acción espontánea puede tener un contenido predeterminado, sin tener que ser considerada, por ese motivo, una acción originada en algo externo. La libertas spontaneitatis representa, por tanto, una concepción antivoluntarista que, por una parte, evita que se tenga que hipostasiar la voluntad $\mathrm{y}$, por otra parte, hace que sea concebible una objetividad concreta de la acción que, como tal, no es una 'opción', sino que se presenta como una efectuación determinada. La libertad, en el sentido de la libertas spontaneitatis, es, entonces, una libertad de la cual tenemos una experiencia objetiva; es una libertad de cuya existencia real se tiene certeza y que, sin embargo, no se presenta como opuesta a otras formas de causalidad. Ello se debe a que la tradición de la libertas spontaneitatis concibe la libertad como efectuación o realización de algo existente; realización que puede estar coordinada con otras realizaciones de algo existente, sin que por ello esa coordinación se convierta en una constricción externa.

Para entender exactamente esto último, vale la pena echar una mirada al Discours de Métaphysique de Leibniz (1875-1890: 458), donde leemos que "toute substance a une parfaite spontaneité (qui devient liberté dans les substance intelligentes)". La 'espontaneidad' se vuelve aquí un atributo 
fundamental de la substancia. Y, según el grado de perfección de la sustancia, la espontaneidad puede significar tanto la actividad espontánea natural como la autodeterminación con conciencia. Las dos formas fundamentales de la espontaneidad corresponden respectivamente al orden del 'reino de la naturaleza' o al del 'reino de la gracia' (siendo solo este último un reino de la libertad en sentido estricto).

La metafísica de la Schulphilosophie adopta ampliamente este planteamiento; pero al hacerlo, es plenamente consciente del hecho de que está gravado con algunas hipotecas. En ese sentido, el wolffiano Bilfinger - citado por Kant en conexión con la cuestión de la libertad- aclara expresamente que la libertad, en sentido amplio, solo puede exponerse por medio de la espontaneidad, pero solo si se adopta, al hacerlo, el punto de vista del "sistema leibniziano de la armonía preestablecida" (1725: §337). Cuando, con posterioridad, otros autores apunten hacia otro concepto de libertad - por ejemplo, cuando pongan en juego nuevamente la idea de una libertas indifferentiae o encuentren en la libertad y en el uso de ella algo análogo a una 'contingencia radical'- ello significará también que para entonces esos autores ya no comparten el sistema leibniziano. Y, en efecto, a mediados del siglo XVIII se desata un debate en torno a la libertas spontaneitatis que tiene lugar en términos que se pueden considerar post-leibnizianos. En ese debate también interviene Kant.

\section{La espontaneidad en el Kant pre-crítico: la nova dilucidatio}

La posición de Kant en la discusión del concepto de libertad no ha sido, de ninguna manera, una posición invariable. Antes bien, se ha desarrollado de manera sucesiva hasta llegar al resultado definitivo al que hemos aludido al comienzo. Al inicio de su carrera filosófica, Kant compartió, en lo esencial, la concepción leibnizo-wolffiana de la libertas spontaneitatis. Pero, en esta época, se mantuvo también receptivo respecto de las críticas a esa posición, formuladas por sus contemporáneos. En ese sentido, cuando ya en el momento de la primera Crítica Kant establece la 'espontaneidad absoluta' del liberum arbitrium como criterio decisivo de la libertad, eso ocurre también por el impulso de la libertas spontaneitatis y de la metafísica en la que ella se basa. Anticipando un poco nuestras reflexiones, podemos decir que el giro crítico en el concepto de la libertad, para Kant, consiste en entender que la libertad no puede situarse entre los fenómenos, ni tampoco en una 
espontaneidad esencial de ellos. La libertad remite, más bien, a otra dimensión: la dimensión que Kant denominará mediante el concepto de 'libertad trascendental'.

Concentrémonos, por de pronto, en Kant como un partidario de la libertas spontaneitatis, tal como se lo puede encontrar en la Nova dilucidatio de 1755. En este escrito, destinado a la obtención de la venia legendi, Kant se ocupa especialmente del principio fundamental de Leibniz: el principio de 'razón suficiente' o, como dice Kant allí ( $N D$, AA 1: 393), siguiendo a Crusius, de "razón determinante". El joven candidato a docente de Königsberg menciona en su escrito las objeciones corrientes contra este principio. Estas objeciones han de considerarse especialmente graves, según Kant, cuando desembocan en el hecho de que, mediante el principio de razón suficiente, o determinante, sea introducido nuevamente el 'Fatum de los estoicos' y en que, con ello, y pese a todas las protestas en contrario, se suprima toda moral y toda ética. Wolff, como bien sabe Kant, había sido blanco de la crítica precisamente debido a este peligro, real o supuesto.

El debate en torno al principium rationis sufficientis llegó incluso a ser de interés público luego de que los teólogos intervinieran en él. Entre ellos, hay que nombrar, en primer lugar, al teólogo de Halle Joachim Lange, quien ya en la segunda década del siglo XVIII, en su "Causa Dei et religionis naturalis adversum atheismum", se opuso con vehemencia al supuesto espinozismo y fatalismo de Wolff y, con ello, rechazó con firmeza cualquier confusión de libertad con espontaneidad. Lange se pronuncia, más firmemente que ningún otro, contra semejante confusión y define la libertad, de manera original, como "radix contingentiae, seu eventuum contingentium" (1727: 8). ${ }^{5}$ Kant mismo se refiere en la Nova dilucidatio a los oponentes filosóficos de Wolff. Lo hace explícitamente en el caso de Christian August Crusius, ${ }^{6}$ de Leipzig y de Joachim Georg Darjes, ${ }^{7}$ de Jena. Y, en el debate, toma partido por Wolff; es decir, sostiene, con algunas variaciones de detalle, la solución adoptada como norma en la Escuela. Según esta solución, el principio de razón determinante es enteramente compatible con una acción

\footnotetext{
${ }^{5}$ Para la discusión entre Lange y Wolff en torno de la libertas spontaneitas, v. Kawamura (1996).

${ }^{6}$ En la Nova Dilucidatio (ND, AA 1:393) se recurre a la Dissertatio de usu et limitibus principii rationis determinantis vulgo sufficientis (Leipzig 1743) de Crusius. Como se sabe, Kant comparte en su fase temprana determinados puntos de la crítica de Crusius a Leibniz, sin seguirlo, sin embargo, en sus concepciones teológicas.

${ }^{7}$ En la Nova Dilucidatio (ND, AA 1: 390, 398) Kant se refiere a los Elementa metaphysica, que Darjes había publicado en Jena en 1743.
} 
que nazca de una autodeterminación interna; y, por esa razón, la libertad no ha de ser entendida como indeterminación objetiva (como indiferencia), sino como autodeterminación interna (como espontaneidad).

Kant presenta su concepción de la cuestión en forma de diálogo. El representante de la tesis de la indiferencia, Caius, responde al teórico de la espontaneidad, Titius, quien es a la vez el defensor de la posición de Kant (como hará luego en la Antinomia, Kant le ha dado ya a esta primera exposición suya del problema de la libertad la forma de un pro y un contra, aunque la estructura aquí no sea finalmente antinómica). El diálogo se inicia precisamente con la pregunta de si acaso del principio de razón no se sigue necesariamente que nadie es dueño de sus actos, pues estos están incluidos en una gran red de causas de la que nada puede escapar, y si, de ese modo, no se exime al agente singular de toda culpa y de toda responsabilidad. Titius -el vocero de Kant - responde que, en sentido fáctico, nadie obra sin tener una spontanea propensio hacia una acción determinada. En ese sentido, la conexión universal que determina todas las cosas, a la cual apunta el principio de razón, no significa que solo pueda haber acción en el sentido de una causación lineal externa. En verdad, respecto de esta conexión universal, es innegable que no puede haber acción sin actividad espontánea, sin autodeterminación que conduzca a una actividad determinada. En vez de ello, la idea de una conexión universal determinante de todas las cosas pone de manifiesto que el obrar recibe su contenido concreto, en cada caso, únicamente en el marco de una determinación ya dada y que, por eso, no puede ser simplemente el resultado de la indiferencia respecto de lo determinado dado. En este contexto, Kant define la espontaneidad con estas palabras: "spontaneitas est actio a principio interno profecta. Quando haec repraesentationi optimi conformiter determinatur, dicitur libertas" (ND, AA 1: 402). Si se mira esta definición a la luz de los debates de la época, puede resultar poco llamativa. Eso es así, por ejemplo, si se la analiza en relación con los dos niveles que contiene (espontaneidad y libertad) y que ya se encuentran en Leibniz. Pero, en una segunda mirada, sí resulta llamativa, pues Kant no introduce en ella la espontaneidad como principio del obrar libre, tal como es habitual en los wolffianos. En cambio, identifica la espontaneidad con la acción misma [actio], cuando dicha acción procede de un principio interno y no de una causación externa: "Espontaneidad es una acción efectuada a partir de un principio interno" ["spontaneitas est actio a principio interno profecta"], afirma Kant, y no, como por ejemplo sostiene Reusch 
(1735: §502), “espontaneidad es el principio interno por el cual el agente se determina a actuar" ["SPONTANEITAS est principium internum, quo agens se ad agendum determinat"]. ${ }^{8}$ Analicemos dos aspectos novedosos de los varios que propone este desplazamiento, que va de la espontaneidad, como principio del obrar libre, a la espontaneidad como acción, cuando esa acción es efectuada a partir de un principio interno.

En primer lugar, con la versión que sitúa la espontaneidad en la acción misma y que le otorga así a la acción una especie de 'carácter de acontecimiento' reforzado, Kant da un primer paso que lo aparta de una interpretación ontológica de la espontaneidad como la que habíamos encontrado, por ejemplo, en Leibniz. En efecto, con esta versión de la espontaneidad, Kant se compromete mucho menos que cualquier otro representante de la tradición de la libertas spontaneitatis con el 'sistema de la armonía preestablecida', entendido como el marco que se debe presuponer necesariamente para darle una coherencia interna al obrar libre. En cambio, se afirma ahora que las acciones son espontáneas y, por eso, que están referidas a un principio, de modo que no tenemos que afirmar que todo lo que es sea por la sabiduría de la espontaneidad y desemboque, en ese sentido, en acciones. Por otro lado, y en segundo lugar, en tanto que la acción misma es vista como el lugar de la espontaneidad, esto es, de la libertad, se da con ello un paso hacia la 'espontaneidad absoluta' de la tercera antinomia; y esto teniendo en cuenta que en la Nova Dilucidatio Kant no intenta sustraer la espontaneidad, esto es, la libertad, del contexto del mundo empírico. Por el contrario, Kant afirma que la libertad no escapa a la fundamentación de las acciones, que puede ser referida a la inclinación, e incluso que un hombre es tanto más libre cuanto más ajustada a la ley sea la fundamentación de su obrar. ${ }^{9}$ Pero en todo ello no hay ninguna causación externa o mecánica. Lo que hay es la percepción de 'motivos' en relación con los cuales se obra.

Tampoco tiene efecto, para Kant, el argumento que el oponente presenta en el diálogo de la Nova Dilucidatio y que consiste en afirmar que

\footnotetext{
${ }^{8}$ La cita completa de Reusch dice lo siguiente: "SPONTANEITAS est principium internum, quo agens se ad agendum determinat: ACTIONES SPONTANEAE dicuntur, qua a spontaneitate profiscuntur; adeoque nullum habent principium determinans externum. Nulla vis externa volitiones atque nolitiones in anima elicit [...]; non tamen sine motivis existunt volitiones atque nolitiones [...]: unde anima se ipsa, motivis suis convenienter, determinat ad volendum atque nolendum; adeoque hi actus sunt spontanea". De este modo, Reusch pone en claro que obrar de 'manera espontánea' no significa obrar 'sin motivación', sino que significa un obrar motivis suis convenienter.

${ }^{9} N D$, AA 1: 401: "Quo huic legi [sc. la ley de la "inclinatio"] certius alligata est hominis natura, eo libertate magis gaudet".
} 
Dios, al tolerar el mal moral, sería - al menos indirectamente - el creador de ese mal moral. Este argumento no tiene efecto porque si bien Dios ha creado distintos grados de perfección y no ha omitido ninguno (esto es, no ha omitido la imperfección), sin embargo, no le ha quitado al agente la autodeterminación en el obrar (lo que implica que el agente es el responsable de ese obrar) (v. ND, AA 1: 404). "In interno semet determinandi principio resederit malorum origo", afirma expresamente el interlocutor como respuesta ( $N D$, AA 1: 405ss). Al hombre no le es imposible determinarse hacia una perfección menor. Por el contario, ello es posible si las facultades de conocimiento superior nos proporcionan motivos para tomar una dirección distinta de la de una perfección mayor. Lo decisivo es siempre que el propio obrar es un obrar motivado intrínsecamente y que, en ese sentido, es libre; que el hecho de que el obrar pueda estar sujeto a motivaciones - esto es, que la totalidad de los fenómenos pueda ser comprendida como un gran conjunto motivacional - es algo que no colisiona con el obrar libre y que, en vez de ello, hace patente que la libertad efectiva ya está implicada en el mundo; esto es, que la libertad está determinada de manera cosmológica, aunque no esté sujeta a coacción, y que, por ello, significa algo más real que lo que ocurre en el caso de las abstracciones de la libertas indifferentiae, del liberum arbitrium o del equilibrio en la decisión.

Precisamente a causa de su compatibilidad con el principio de razón, la libertad posee, incluso para el Kant pre-crítico, una dimensión eficiente real. Esa dimensión real no es, como lo era para Leibniz, la de una espontaneidad monádica existente. Pero es, al menos, la de una interioridad que es representada por acciones externas, las cuales, desde el punto de vista de su contenido, trascienden el contexto en el que se encuentran; pero que, sin embargo, siguen siendo acciones referidas a un contenido. El problema que se planteará al respecto con el giro crítico de la filosofía de Kant es este: determinar realmente en qué sentido puede ser pensada una implicación mutua de libertad y mundo; en qué medida la libertad efectivamente es 'algo' en relación con otras cosas determinadas, o hasta qué punto se la debe pensar en otra relación. En ese sentido, la tercera antinomia pretende llamar la atención acerca de que el concepto de una 'libertas spontaneitatis', bien mirado, contiene una contradicción: la de que la libertad previa a toda cosa, aunque sea comprendida como algo en ejecución, siempre es tomada ontológicamente. 


\section{La tercera antinomia}

Cuando Kant, en el contexto de la tercera antinomia, afirma que "por libertad, en sentido cosmológico" entiende "la facultad [que tiene un agente], de comenzar un estado por sí mismo" (KrV A533/B561; v.t. A446/B474), resulta más que clara, ya en la elección de las palabras, la conexión con la tradición de la libertas spontaneitatis. De hecho, la expresión 'por sí mismo' no es más

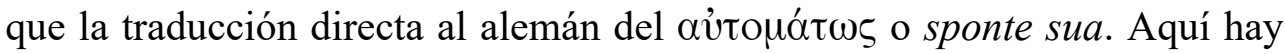
varios aspectos que deben ser atendidos.

El primero de ellos es que la formulación de Kant no solo admite una interpretación en términos de la antigua doctrina de las causas espontáneas, sino que, incluso en un sentido específico, favorece esa interpretación. Esto quiere decir que el concepto kantiano cosmológico de la libertad, tal como es introducido aquí, en principio, remite a la actividad autónoma de una cosa. El concepto de esa actividad autónoma ya estaba presente en el concepto de la espontaneidad, como ocurre por ejemplo en el caso de la doctrina aristotélica de la generación espontánea (una doctrina que sigue teniendo efectos hasta el siglo XVIII); o, como ocurre también en el caso de Glocenius y de otros, que apunten a la espontaneidad como a una forma de actividad de la naturaleza que se encuentra presente tanto en los animales como en el fuego, e incluso en un resorte de acero. Kant mismo, como hemos visto, distingue en la Nova Dilucidatio entre una 'acción' espontánea que tiene lugar a partir de un principio interno y una acción que, además de ello, es dirigida por una representación de lo bueno; esto es, una acción que se remite a una actividad reflexiva y no a una cosa. Solo esta última acción, esto es, la que es dirigida por una representación de lo bueno, puede aspirar a ser libre en sentido propio. Aquí lo significativo es que la libertad ya no es pensada como un principio interno, ni mucho menos como una auto-realización sustancial, como ocurría en el caso de Leibniz; en cambio, ahora queda unida a su inconmensurabilidad respecto del orden de los fenómenos. La libertad ahora es 'espontaneidad absoluta', un concepto que en cierta medida reemplaza y se opone a aquella spontaneitas perfecta que, inspirada por Leibniz (y a la cual también se había referido Bilfinger en 1725), todavía entiende lo sensible como algo en cierto modo activo. Como hemos visto, Kant ya se ha distanciado de una opción como esa en la medida en que, en la Nova Dilucidatio, sitúa la espontaneidad, y con ella la libertad, en el obrar y no en el principio que rige el obrar. Ahora, en el estadio correspondiente a la $\mathrm{Kr} V$, 
lo que está en discusión es si en el plano de los fenómenos puede 'haber' espontaneidad y, con ella, libertad entendida - por decirlo así- como un concepto límite. Pero también se discute qué sentido podrán tener las ambivalencias que acompañan el concepto de esa espontaneidad absoluta. En efecto, el concepto de una espontaneidad absoluta conduce inevitablemente, según Kant, a la antinomia de la razón; una antinomia en la cual queda destruido el concepto de una espontaneidad (o libertad) objetiva y que, sin embargo, a la vez, hace aparecer así el concepto de una libertad que no es objetual, sino trascendental. Queda todavía por aclarar cuál es la relación de esa libertad trascendental con el mundo de los objetos, y queda por aclarar también cuál es la relación de esa libertad con la esfera de la acción.

Así, la tercera antinomia puede ser leída como una crítica ampliada a Leibniz, a saber, como una crítica cuyo núcleo es la superación de la representación de una espontaneidad sustancial presente ya en los fenómenos. Pero también se la tiene que entender como el lugar en que se hace consciente la relación práctica en la que nos encontramos respecto de nosotros mismos y que se manifiesta como una relación no objetual. De la tercera antinomia resulta, pues, la posibilidad de pensar la libertad entendiéndola como la 'idea trascendental de la libertad'. Esa posibilidad se vuelve necesidad para el concepto práctico de libertad. Para este concepto práctico, se hace necesario pensar la libertad como "idea transcendental de la libertad", idea que — según Kant - remite expresamente al "concepto práctico de la libertad" ( $\mathrm{KrV}$ A533/B561). Gracias a este salto, el concepto de la libertad práctica puede ser expresado incluso en el lenguaje de la tradición de la libertas indifferentiae. En efecto, Kant dice expresamente que la "libertad, en sentido práctico", se funda en la "independencia del arbitrio respecto de la constricción por estímulos sensibles" y que incluso como "arbitrium sensitivum" la libertad tiene que ser entendida siempre como un "arbitrium liberum" (KrV A534/B562).

Volvamos brevemente al concepto de una 'espontaneidad absoluta', un concepto que todavía no fue explicado de manera concluyente y para el cual, como ya hemos dicho, no hay precedentes inmediatos en la tradición. 


\section{Libertad trascendental}

Cuando se pregunta qué sentido puede tener hablar de una 'espontaneidad absoluta', inmediatamente queda claro que la espontaneidad, entendida así, implica abandonar aquella solución del problema de la libertad que se basaba en la libertas spontaneitatis. Dicha solución se abandona, por ejemplo, en la medida en que la tradición distingue una causalidad externa y una interna y habla de 'libertad' cuando queda excluida la causación externa (o cuando puede quedar reducida a una mera razón circunstancial), pero no por eso se excluye una causación interna o motivación. Este fue el modo como los representantes de la Schulphilosophie - como hemos visto- lograron conciliar el principio de razón con la libertad, mientras que los críticos de una validez irrestricta del principio de razón — como por ejemplo Crusius (1753: $\S 70-\S 78$; v.t. Kawamura 1996) — se apoyan, por su parte, en un "arbitrium liberum" real (como "fuerza fundamental") que tendría que ser capaz de producir, enteramente por sí mismo, un comienzo. Por otro lado, en la diferenciación que hace la Schulphilosophie entre una causalidad (externa) —que Kant llama 'mecánica' — y una (interna) —que Kant llama 'psicológica' - así como en el intento de identificar la libertad, entendida como espontaneidad, con la causalidad psicológica (interna), Kant ve un "concepto comparativo de libertad" (KpV AA 5: 96). Este concepto - afirma Kant - constituye una solución ilegítima que solo es útil para resolver "un problema difícil con una pequeña manipulación de palabras", conservando la idea de que las acciones, dentro del orden temporal, se pueden deducir de un estado precedente. La 'espontaneidad absoluta', por el contrario, no puede tener ninguna relación con un orden temporal concreto. Antes bien, ella consiste en la negación del orden temporal como un todo.

Como sabemos, Kant da cuenta de esto último, entre otras cosas, mediante la diferencia entre un carácter empírico y uno inteligible, en lo cual no es necesario detenerse aquí. En cambio, debemos ocuparnos todavía del punto mencionado al comienzo y que sigue pendiente: el hecho de que, para Kant, la idea trascendental de la libertad sea la única de las ideas que prueba su realidad por sí misma; esto es, que ella, la libertad, puede "demostrarse en acciones, y por lo tanto en la experiencia" y, de ahí, que "debe ser incluida entre los scibilia" (KU, AA 5: 468). A modo de cierre, intentemos aproximarnos brevemente al contenido central de esta tesis. 
La respuesta general a la cuestión planteada, esto es, a la pregunta por el concepto cosmológico kantiano de la libertad, solo puede ser una respuesta negativa: no se puede representar la libertad en la cosmología. Ella, la libertad, no 'aparece' en el campo de nuestra experiencia objetiva; y esto es así, sin que se pueda inferir de ello, no obstante, que no hay libertad, pues ella puede ser dada, por ejemplo, en el plano de los elementos constituyentes de la experiencia. Estos llegan a incluir la espontaneidad del entendimiento y también la forma de la autoconciencia que se presenta en la apercepción transcendental, y llegan a abarcar también el problema de la libertad propiamente práctica al que Kant ya se refiere en la Antinomia. La doctrina de la libertas spontaneitatis presupone que en los fenómenos de la espontaneidad natural, y especialmente en los fenómenos de la espontaneidad natural voluntaria, haya, indudablemente, una libertad que se manifiesta de manera objetiva, esto es, una libertad cuya esencia es su puesta en acto, es decir, su estar actuando. La metafísica de Leibniz es seguramente el intento más impresionante de la filosofía moderna de pensar la espontaneidad como principio del ser y, en conexión con esto, de pensar el activo ser-sí-mismo como ser-libre. Como hemos visto, este ser-libre no contradice el principio de razón suficiente, en la medida en que la determinación interna puede unirse armónicamente con otras determinaciones sin convertirse por eso en una determinación externa. Teniendo en cuenta esta concepción fundamental resulta comprensible que en la escuela leibnizo-wolffiana la libertas spontaneitatis incluya siempre momentos reflexivos. Un ejemplo de ello es la definición que se encuentra en las Institutiones metaphysicae de Baumeister, que Kant emplea en sus lecciones de metafísica más tempranas: "Facultas animae seipsam determinandi dicitur Spontaneitas, et ea actio, ad quem se ipsa determinat anima, dicitur spontanea" (1783: §672). Según la filosofía crítica de Kant, empero, precisamente la autodeterminación no puede proyectarse sobre el plano de los fenómenos; en este plano solo resultan visibles las series de imágenes fenoménicas según el orden del tiempo, en cuya forma ya está presente la irreflexividad y, con ella, únicamente la posibilidad de determinar otra cosa, pero nunca la de la autodeterminación.

Por cierto, el abandono del concepto de una libertad que pueda aparecer como fenómeno, o que sea, de algún modo, objetiva, no significa que el concepto de libertad quede vacío o se vuelva obsoleto. Por el contrario, gracias a la antinomia de la razón, se presenta la posibilidad de hacer que la 
libertad vuelva sobre sí misma. A este retorno quisiera entenderlo aquí como un retorno hacia una apropiación de la libertad que ya no es objetiva, sino trascendental y práctica. Kant concibe este retorno de la libertad hacia sí misma por medio de los tres conceptos de 'espontaneidad absoluta', 'libertad trascendental' y 'libertad práctica'. En ese sentido, este mencionado retorno de la libertad hacia sí misma puede entenderse como el despertar de la conciencia de la libertad en general; conciencia que - puesto que la libertad no puede aparecer como fenómeno- solo puede comprenderse o concebirse cuando ocurre en acto. Esa conciencia de la libertad se concibe de una manera más aproximada cuando se entiende la libertad como libertad trascendental, es decir, cuando se la concibe, aun en su inconmensurabilidad respecto del mundo fenoménico, como referida al mundo fenoménico e incluso como constitutiva de ese mundo. Ese mundo, como totalidad, debe su constitución a las acciones del entendimiento, cuya influencia llega hasta la unidad de las formas de la intuición a priori. La libertad, como libertad trascendental, puede, por tanto, ser comprendida como la conciencia de sí que corresponde a la conciencia de objeto. Esa conciencia sabe respecto de sí misma, ciertamente, que nunca podrá aparecer como fenómeno, en sentido teórico, en el plano de los objetos. Sin embargo, como libertad práctica, la libertad tiene conciencia de que puede objetivarse: tiene conciencia de que puede, al obrar, establecer otro orden de las cosas respecto del que está dado; o sabe que ella puede ser, en general, 'causa' con respecto a un mundo que está determinado de otro modo respecto de aquel mundo que aparece como fenómeno. Este saber acerca de una posible 'causalidad por libertad' no es equiparable al saber que es teórico en sentido propio; no obstante, no es por ello un saber vacío ni un saber solo aparente. Es, como lo hemos dicho, ante todo, un saber acerca de la posibilidad de un mundo diferente frente a aquel que se encuentra dado. Por tanto, este saber es representado como liberum arbitrium: al obrar nos motivamos siempre a partir de la alternativa a la luz de la cual vemos las cosas.

Sin embargo, la libertad no es solamente posible, sino que es también libertad real. Esta realidad de la libertad es la realidad de la espontaneidad absoluta, en la cual la libertad elige. ¿Qué elige la libertad en esta espontaneidad absoluta? La respuesta es fácil: en primer lugar, se elige a sí misma; es decir, se decide a ser libertad trascendental y, dentro de esta, libertad práctica. Y precisamente con esto se explica el enunciado de Kant que dice que la libertad, como idea, ya está siempre realizada y es un hecho: 
pues todo aquel que comprenda la antinomia de la libertad, es decir, que entienda que el ser libre no puede aparecer nunca inmediatamente como fenómeno, porque la libertad no pertenece al orden de las cosas, sino al orden de la referencia a las cosas, ha entendido también que la libertad llega a su realización, ante todo, con referencia al orden de las cosas en su totalidad; es decir, ha entendido que también él llega a sí mismo solo al apartarse del orden de las cosas, que puede concebir también como un orden diferente. En la medida en que puede hacer esto, se ha elegido a sí mismo como un ser libre; es decir, ha llegado a ser consciente de sí mismo, fuera del orden del tiempo; ha llegado a ser consciente de sí mismo como causa de otro orden de cosas. Ese 'otro orden' no significa la supresión de las leyes de los fenómenos (como lo teme la antítesis que, en la Antinomia, es la abogada del principio de razón). Significa, antes bien, establecer una legislación por libertad, que se realiza al obrar y que al mismo tiempo me realiza a mí mismo al obrar. La deconstrucción de la concepción de la libertad como objeto (concepción que había aparecido con el concepto de la libertas spontaneitatis) conduce así a otra concepción según la cual el sujeto práctico se genera a sí mismo mediante sus acciones conformes a la ley de la libertad; es decir, conformes a la autonomía. Y puesto que ese obrar (que es un producirse a sí mismo mediante la acción) es un obrar que se encuentra siempre como ya habiendo comenzado, resulta que también la libertad puede concebirse solamente como aquella idea transcendental (y no empírica) que es siempre efectivamente real. Quienquiera que haya comprendido la antinomia de la libertad, ha dado efectiva realidad a la libertad en el sentido de espontaneidad absoluta. Y, con ello, ha comprobado que se puede saber algo acerca de la libertad; es decir, ha comprobado que la libertad es un scibile, esto es, algo que puede conocerse. Pero lo decisivo es que con ello el horizonte de la razón permanece abierto ante las cosas (que parecen ser absoluta y definitivamente tal como se presentan). La libertad se sitúa siempre en ese horizonte abierto.

\section{Referencias}

BAUMEISTER, F. C.: Institutiones metaphysicae Ontologiam, Cosmologiam, Psychologiam, Theologiam denique naturalem Complexae. Wittenberg / Zerbst, 1783.

BILFINGER, G. B.: Dilucidationes philosophicae de Deo, anima humanam et generalibus rerum affectionibus, Tübingen, Olms Verlag, 1725. 
: Dilucidationes philosophicae de Deo, anima humanam et generalibus rerum affectionibus, Hildesheim, Olms Verlag, 1982.

CRUSIUS, C. A.: Dissertatio de usu et limitibus principii rationis determinantis vulgo sufficientis, Leipzig, Olms Verlag, 1743.

: Enwurf der nothwendigen Vernunft Wahrheiten, Leipzig, Olms Verlag, 1753.

: Enwurf der nothwendigen Vernunft Wahrheiten, Darmstadt, Wissenschaftliche Buchgesellschaft, 1963.

DARJES, J. G.: Elementa metaphysica, Jena, 1743.

FICHTE, J. G.: "System der Sittenlehre”, en FUCHS, E.; GLIWITZKY, H.; LAUTH, R.; SCHNEIDER, P. K. (eds.): Gesamtausgabe der Bayerischen Akademie der Wissenschaften, vol. 1, Stuttgart-Bad Cannstatt, Frommann, 1798.

: "System der Sittenlehre", en FUCHS, E.; GLIWITZKY, H.; LAUTH, R.; SCHNEIDER, P. K. (eds.): Gesamtausgabe der Bayerischen Akademie der Wissenschaften, vol. 1, Stuttgart-Bad Cannstatt, Frommann, 1970.

FINSTER, R.: "Spontaneität, Freiheit und unbedingte Kausalität bei Leibniz, Crusius und Kant”, Studia Leibnitiana XIV, 2 (1982) 266-277.

: Spontaneität und Freiheit. Eine Untersuchung zu Kants theoretischer Philosophie unter Berückchsichtigung von Leibniz, Wolff und Crusius, Trier, Universität Trier, Tesis Doctoral, 1984.

GOCLENIUS, R.: Lexicon philosophicum quo tanquam clave philosophiae fores aperiuntur, Frankfurt am Main, Marchioburgi, P. Musculi, 1613. : Lexicon philosophicum quo tanquam clave philosophiae fores aperiuntur, Hildesheim, Olms Verlag, 1964.

HOBBES, T.: "Tripos III: Of Liberty and Necessity", en MOLESWORTH, W. (ed.): The English Works of Thomas Hobbes of Malmesbury, vol. 4, Londres, 1840.

: "Tripos III: Of Liberty and Necessity", en MOLESWORTH, W. (ed.): The English Works of Thomas Hobbes of Malmesbury, vol. 4, Darmstadt, Aalen, 1966. 
HOFFMANN, T. S.: "Spontaneität”, en RITTER, J. v.; GRÜNDER, K. (eds.): Historisches Wörterbuch der Philosophie, 1424-1434, vol. 9, Basel/Darmstadt, Verlag Scheidegger and Spiess, 1995.

KANT, I.: "Principiorum primorum cognitionis metaphysicae nova dilucidatio", en: Königlich Preußische Akademie der Wissenschaften (ed.): Kant's Gesammelte Schriften Akademie-Ausgabe [AA], vol. 1, Berlín, Königlich Preußische Akademie der Wissenschaften, 1900ss.

: Kritik der reinen Vernunft [KrV], AA, vol. 3, 4, Berlín, Königlich Preußische Akademie der Wissenschaften, 1781-1787.

: Kritik der praktischen Vernunft [KpV], AA, vol. 5, 1788.

: Kritik der Urteilskraft [KU], AA, vol. 5, 1790.

KAWAMURA, K.: Spontaneität und Willkür. Der Freiheitsbegriff in Kants Antinomienlehre und seine historische Wurzeln, Stuttgart-Bad Cannstatt, Frommann, 1996.

LANGE, J.: Causa Die et religionis naturalis adversum atheismus, Halle, 1727.

: Causa Die et religionis naturalis adversum atheismus, Hildesheim, Olms Verlag, 1984.

LEIBNIZ, G. W. "Discours de Métaphysique", en GERHARDT, C. J. (ed.): Die philosophischen Schriften von Gottfried Wilhelm Leibniz, vol. IV, Berlín, Weidmann, 1875-1890.

: "Discours de Métaphysique", en GERHARDT, C. J. (ed.): Die philosophischen Schriften von Gottfried Wilhelm Leibniz, vol. IV, Hildesheim, Olms Verlag, 1965.

REUSCH, J. P.: sistema metaphysicum antiquiorum atque recentiorum ítem propia dogmata et hypotheses exhibens, Jena, 1735.

: sistema metaphysicum antiquiorum atque recentiorum ítem propia dogmata et hypotheses exhibens, Hildesheim, Olms Verlag, 1990.

TETENS, J. N.: Philosophische Versuche über die menschliche Natur und Ihre Entwicklung, Leipzig, Weidmann, 1777.

: Philosophische Versuche über die menschliche Natur und Ihre Entwicklung, Hildesheim, Olms Verlag, 1979. 


\title{
From the unity of sensible intuition to the sensible unity of intuition: revisiting the proof-structure of Kant's B- Deduction argument
}

\author{
ADRIANO PERIN ${ }^{1}$
}

\begin{abstract}
The B-Deduction accounts for Kant's utmost solution at safeguarding both the distinctiveness and a necessary relation between understanding and sensibility. I aim at proposing an original thesis to the debate on this solution: the B-Deduction argument profits from a methodology correlating the unity of sensible intuition to the sensible unity of intuition. At first, Kant's definition of "transcendental cognition" is set forth. Secondly, an inquiry into the argument's methodology is carried out. After that, the justification of the categories within the understanding's domain is taken into account. Finally, the relation of the understanding to sensibility is brought into discussion.
\end{abstract}

Keywords: deduction, understanding, sensibility, categories, unity of intuition

\section{De la unidad de la intuición sensible a la unidad sensible de la intuición: revisitando la estructura de prueba del argumento kantiano de la Deducción-B}

\begin{abstract}
Resumen
La Deducción-B representa la última solución de Kant tanto para la preservación de la diferenciación entre entendimiento y sensibilidad como para el establecimiento de una relación necesaria entre esas facultades. Mi objetivo es proponer una tesis original al debate sobre esta solución: el argumento de la Deducción-B se beneficia de una metodología que correlaciona la unidad de la intuición sensible a la unidad sensible de la intuición. Primeramente, presento la definición kantiana de “conocimiento trascendental". Enseguida, investigo la metodología del argumento. Después, considero la justificación de las categorías en el dominio propio del entendimiento. Por fin, discuto la relación del entendimiento a la sensibilidad.
\end{abstract}

Palabras clave: deducción, entendimiento, sensibilidad, categorías, unidad de la intuición

\footnotetext{
${ }^{1}$ Câmpus Criciúma do Instituto Federal de Santa Catarina (IFSC).

Contact: adriano.perin@ifsc.edu.br.
} 
1. An overview of the problem

Kant finds in the term 'transcendental' the expression of the singularity of his philosophy. This is due to the fact that this philosophy attends to a particular kind of cognition, i.e., that which aims at grounding what is empirical without counting on anything transcendent.

At first glance, it might appear that, represented in such a description, the definition of cognition is invariably accurate. Yet, one must not forget that, in the two editions of the Critique of pure reason, Kant gives two different definitions of 'transcendental cognition'.

In the 1781 edition, Kant states: "I call transcendental all cognition that is, in general, occupied not so much with objects but rather with our $a$ priori concepts of objects" ( $\mathrm{KrV} \mathrm{A} 11$, a. trans.). ${ }^{2}$ In the 1787 edition, he states "I call transcendental all cognition that is, in general, occupied not so much with objects but rather with our manner of cognition of objects insofar as this is to be possible a priori" ( $\mathrm{KrV} \mathrm{B} 25$, a. trans.).

A thorough discussion of this difference requires addressing the following questions: i) What is the meaning of Kant's change in the seminal label of his philosophy? ii) Why Kant no more took the task of his philosophy to be restricted to mere 'concepts' and presented it as endorsing 'our manner of cognition of objects'? iii) What was missing in the former approach, so that Kant saw the necessity of presenting a second definition?

It has been noted in the secondary literature that, with the change in the definition of 'transcendental cognition', Kant aimed at including in it his argumentation either in the Aesthetic (Erdmann 1900: 28), or in the Dialectic (Hinske 1970: 39), or even still in the Doctrine of Method (Baumanns 1997: 93).

\footnotetext{
${ }^{2}$ The German text here reads: "Ich nenne alle Erkenntniß transcendental, die sich nicht sowohl mit Gegenständen, sondern mit unsern Begriffen a priori von Gegenständen überhaupt beschäftig”. In the way in which '"̈̈berhaupt' is placed in this sentence, it can be understood either as an adjective (therefore, related to 'Gegenständen') or as an adverb (therefore, related to 'beschäftig'). In the passage from the second edition, which is presented in the following, Kant makes it clear that 'überhaupt' is presented as an adverb: "Ich nenne alle Erkenntniß transscendental, die sich nicht sowohl mit Gegenständen, sondern mit unserer Erkenntnißart von Gegenständen, so fern diese a priori möglich sein soll, überhaupt beschäftigt" ( $K r V$ B25). In quoting the Critique of pure reason, I use the standard reference to $\mathrm{A}$ and $\mathrm{B}$, indicating the first and second edition respectively. I generally follow Paul Guyer's translation mentioned in the References section. Whenever I do not, I indicate it in the corresponding footnote. All other Kant's texts are referenced in the Akademie Ausgabe (AA), with volume and page. In all quotations, emphasis is my own.
} 
In this essay, I argue that the change in the definition of 'transcendental cognition' is due to Kant's approach of the task of the deduction of the categories in the B-Deduction argument. So, I maintain that, in the change provided in the 1787 Introduction, Kant is assuring that, in the B-Deduction, he had finally accounted for the relation of the faculties of sensibility and understanding and, therefore, for 'our manner of cognition of objects'.

The thesis advanced is that this account relies on a methodology that presents the categories as concepts grounding the unity of sensible intuition and then leads into their justification as presiding over the sensible unity of intuition.

This thesis is supported, in the following sections of the paper, in three moments: the next section discusses the method followed in the B-Deduction argument; the third section deals with the justification of the categories within the domain of the faculty of the understanding; the fourth and final section delves into the task of relating the understanding to sensibility.

2. On the method of argumentation followed in the B-Deduction argument

In a passage from the Introduction to the second edition of the Critique, Kant points out that the analytic method is not sufficient for taking into account the task of philosophy:

[...] the mere analysis of the concepts that inhabit our reason a priori, is not the end at all, but only a preparation for metaphysics proper, namely extending its a priori cognition synthetically, and it is useless for this end, because it merely shows what is contained in these concepts, but not how we attain such concepts a priori in order thereafter to be able to determine their valid use in regard to the objects of all cognition in general (KrV A13-14/B23-24).

Making sense of Kant's claim that analysis of concepts 'is not the end' [Zweck] in philosophy and, moreover, is useless [untauglich] for this end, requires that we catch on what he means by 'end'. By 'end', in this claim, Kant means a fundamental condition of justification in which a procedure peculiar to philosophy is carried out. Since such a procedure in philosophy implies 'extending its a priori cognition synthetically', it must be a synthetic 
one, ensuring, conjointly and necessarily, that concepts are attained a priori and have a valid use.

By focusing on the B-Deduction argument, one can say that what Kant is holding is that a method which provides "the mere analysis of the concepts that inhabit our reason a priori" and, with this, "shows what is contained in these concepts" is not appropriate for ensuring both the validity of pure concepts within the domain of the understanding and likewise their legitimate use in the domain of sensibility. As Kant puts it: "[...] this analysis would not be purposeful [zweckmäßig], since it does not contain the difficulty encountered in the synthesis on account of which the whole Critique is actually undertaken" ( $\mathrm{KrV}$ B27-28).

Given this, one must also consider that Kant does not dismiss the analytic means which, as backward or preparatory procedures, conduct his argumentation to that fundamental condition of justification defined as the 'end'. As he points it out: "[a] great part, perhaps the greatest part, of the business of our reason consists in analyses of the concepts that we already have of objects" ( $\mathrm{KrV}$ A5/B8). Yet, with regard to the ground of this great(est) business, Kant immediately ensures, in the following, that "[...] reason adds something entirely alien to given concepts and indeed does so a priori" ( $\mathrm{KrV}$ A6/B10).

On the basis of the account that the analytic method is a way back to a justification which can only be given by a synthetic method, one can also grasp what Kant was getting at in this warning: "[...] we need to take the analysis only as far as is indispensably necessary in order to provide insight into the principles of a priori synthesis in their entire scope, which is our only concern" (KrV A12/B25).

In light of these considerations given in the B-Introduction-namely, the conception of analysis as insufficient but as a necessary first procedure for the approach of the task of the deduction - one can find a methodological hint to the structure of Kant's B-Deduction argument.

Kant structures the B-Deduction in such a way that, in its first part, it contends with an 'indispensably necessary' analysis of the domain of the faculty of the understanding; so as to ensure, in its second part, that the synthesis would also provide its relation to the domain of sensibility. While the former is preparatory and indispensable, the latter is 'purposeful' for 
holding the task on behalf of which the "whole Critique is actually undertaken'.

Underlying this methodology lies the recognition that the focus of analysis is no more the total amount of human cognition - which, in the ADeduction, had been presented as a subjective consideration of the faculties supposedly grounding this cognition and, in the Prolegomena, as its 'depuration' out of the domain of sensible perception (see $\mathrm{KrV}$ AXVI-XVII, A97; Prol, AA 04: 297-298). Now, the goal of the analysis is what is pure spontaneity, i.e., the domain of the pure understanding.

This is due to the fact that, in the B-Deduction argument, Kant sees that an analytical procedure is to be advanced only to the extent that the domain of the faculty of the understanding is primarily investigated; so as to ensure that this faculty is the ground of determination of what, by means of its relation to the domain of sensibility, must be justified as a priori cognition. This relation, however, would only be presented by a synthetic method of investigation.

In the following two sections, a consideration of how Kant structures the B-Deduction argument according to these two procedures may give us a key to determining how the task of the deduction is actually fulfilled in this argument.

3. The unity of sensible intuition: rendering the justification of pure concepts without any help from the domain of sensibility

Before undertaking the arduous task of facing Kant's dense argumentation within $§ 15-\S 20$ of the B-Deduction, it is helpful to briefly consider that the introductory section of the Transcendental Logic, presented in the 1781 edition and maintained in the 1787 edition, offers the ground upon which a deduction of the categories had to be advanced. In a word, we must initially take into account Kant's insight into the need for a first-step argument attending exclusively to the domain of the faculty of the understanding.

As the starting point, Kant sets the peculiarity of the faculty of the understanding: 
[t]he pure understanding separates itself completely not only from everything empirical, but even from all sensibility. It is therefore a unity that subsists on its own, which is sufficient by itself, and which is not to be supplemented by any external additions ( $\mathrm{Kr} V \mathrm{~A} 65 / \mathrm{B} 89-90)$.

In the context of this characterization, one reads the nature of a consideration of understanding within its own domain: "[...] we isolate the understanding [...] and elevate from our cognition merely the part of our thought that has its origin solely in the understanding" ( $K r V$ A62/B87).

Since, in this consideration, it is not given that element which, " $[\ldots]$ to us [humans]", "[...] takes place only insofar as the object is given to us" ( $K r V$ A19/B33) - i.e., intuition in the domain of sensibility-; what remains is merely "[...] the expectation [...] that there can perhaps be concepts that may be related to objects a priori, not as pure or sensible intuitions but rather merely as acts of pure thinking" $(K r V \mathrm{~A} 57 / \mathrm{B} 81)$.

On the basis of this specific situation that is presented in the justification of the categories, Kant ponders that the above-cited 'expectation' could only be ferreted out by means of an 'analytic of concepts'.

Nevertheless, Kant is convinced that, in such a procedure, he can neither follow the tradition nor his own account in the 1760s on behalf of an analysis that, while rendering concepts clear(er), would be the only method to be followed in philosophy. ${ }^{3}$ As he puts it:

I understand by an analytic of concepts not their analysis, or the usual procedure of philosophical investigations, that of analyzing the content of concepts that present themselves and bringing them to distinctness, but rather the much less frequently attempted decomposition of the faculty of understanding itself [Zergliederung des

\footnotetext{
${ }^{3}$ Here is a point of disagreement with Caimi (2014: 11-12). Caimi argues that "[i]f we observe the argumentative course Kant takes in the Critique of Pure Reason, and especially in the development of the Transcendental Deduction, we find that it closely coincides with the description of the method of philosophy he had expounded in some of his 1762-1763 writings. Whoever proceeds according to this method receives a concept which is initially confused and whose origin is undetermined, and engages in the task of bringing distinction to it". In his reading of this disagreement, Caimi pointed out that he is not asserting that the method of analysis is sufficient for carrying out the task of the Critique, but emphasizing, as I do, that there is a moment of analysis in its argumentative path. Nevertheless, I would like to express my disagreement in the sense that my position seems to be more radical regarding Kant's pre-critical and critical approaches to the method of philosophy. I do believe that in 1760 Kant took analysis to be the single method of philosophy, while the critical Kant took it to be just a way to the development of synthesis, which is now seen as the moment in charge of presenting the ground of any philosophical investigation.
} 
Verstandesvermögens selbst], in order to research the possibility of a priori concepts by seeking them only in the understanding as their birthplace (KrV A65/B90, a. trans.).

Two points of this passage are of particular interest in what matters to the critical importance of the method of analysis. One is Kant's rupture with the previous accounts on the adoption of analysis of the content of cognition and concepts as the unique procedure to be followed in philosophy. In a word, in his critical approach, Kant sees the analytical method not as related to the total amount of human cognition, but solely to one of the faculties grounding this cognition. That is to say, analysis is important to determine or decompose each of the domains of human cognition, i.e., the intuitive domain of sensibility and the discursive domain of the understanding.

In another passage, Kant gives the reason for this restriction in the use of the analytic method:

[...] synthesis alone is that which properly collects the elements for cognitions and unifies them into a certain content; it is therefore the first thing to which we have to attend if we wish to judge about the first origin of our cognition ( $K r V$ A77-78/B103).

This is due to the fact that, in what regards the total amount of our cognition, "[p]rior to all analysis of our representations these must first be given, and no concepts can arise analytically as far as the content is concerned' (KrV A77/B103).

The second point of interest is Kant's adoption of the analytic method in the first part of the B-Deduction argument. In leading away from the application of the analytic method to human cognition in its entirety and moving over to its use so as decompose the faculty of the understanding in its own domain, Kant establishes the way to fulfill the task of the deduction. This means that, in its methodology, the B-Deduction starts with the distinctiveness of the faculties of sensibility and understanding and sets the latter as the one in charge of determining what is giving in the former.

Kant notes that the domain of sensibility had been autonomously justified in the Transcendental Aesthetic, i.e., it alone "[...] traced the concepts of space and time to their sources [...] and explained and determined 
their a priori objective validity" (KrV A87/B119-120). Now, regarding the domain of the understanding, it remains as unsettled the justification that pure concepts "[...] speak of objects not through predicates of intuition and sensibility but through those of pure a priori thinking", i.e., that "[...] they relate to objects generally without any conditions of sensibility" ( $\mathrm{KrV}$ A88/B120).

On this pending matter, Kant states that " $[\mathrm{t}]$ ranscendental philosophy has the advantage but also the obligation to seek its concepts in accordance with a principle, since they spring pure and unmixed from the understanding, as absolute unity" ( $\mathrm{KrV}$ A67/B92).

It is worth taking into account that Kant's use of 'pure' [rein] and 'unmixed' [unvermischt] — which, in other contexts, would be synonyms — is due to the particular context of transcendental philosophy in its justification of the categories as non-empirical (pure) and different from that which belongs to domain of sensibility (unmixed). ${ }^{4}$ Such a justification, in the clue given in the above-cited passage, must start with the consideration of the understanding as 'absolute unity'.

Let us consider how Kant presents, within the B-Deduction argument, the discursivity of human understanding as pure, unmixed and grounded upon the unity of the act of representation.

In $\S 16$, Kant presents the self's act of thinking as an activity belonging solely to the faculty of understanding. According to him, its representation consists of the following attributes: i) "spontaneity": "[...] it cannot be regarded as belonging to sensibility"; ii) "pure apperception": "[...] in order

\footnotetext{
${ }^{4}$ Kant presents, at the beginning of the B-Deduction argument, a defense of the non-empirical (pure) way in which the categories are originated. Accordingly, in the fragment added to $\S 14$ in the second edition, he provides a brief but precise criticism to what he calls 'empirical derivation' of the categories in the attempts advanced by Locke and Hume. As to Locke, Kant states that "[...] because he encountered pure concepts of the understanding in experience, [he] also derived them from this experience, and thus proceeded so inconsistently that he thereby dared to make attempts at cognitions that go far beyond the boundary of all experience" ( $K r V$ B127). With regard to Hume, Kant maintains that he "[...] derived them from experience (namely from a subjective necessity arisen from frequent association in experience, which is subsequently falsely held to be objective, i.e., custom); however he subsequently proceeded quite consistently in declaring it to be impossible to go beyond the boundary of experience with these concepts and the principles that they occasion" (KrV B129). According to Kant, the results of these enterprises are, respectively, fanaticism [Schwärmerei] and skepticism [Skeptizismus]. A deduction of the pure concepts of the understanding is, therefore, "[...] an attempt to see whether we cannot successfully steer human reason between these two cliffs, assign its determinate boundaries, and still keep open the entire field of its purposive activity" ( $K r V$ B129). Once one has done this, that unmixed way in which the categories 'spring' from the understanding would also be ferreted out.
} 
to distinguish it from the empirical one"; iii) "original apperception": "[...] it is that self-consciousness which, because it produces the representation $I$ think, which must be able to accompany all others and which in all consciousness is one and the same, cannot be accompanied by any further representation" $(\mathrm{KrV} \mathrm{B} 132)$.

In addition to the two attributes already considered-i.e., its pure and unmixed character-, now the faculty of the understanding is presented as an act of thinking which is an original apperception. With this characterization, Kant means that the act of thinking is free from all determinations as well as from external and object relations. It represents, therefore, the unity, the identity and the absolute independence of the self from any other representation. Kant states that this 'other representation' could be either an intuition or a concept.

With this characterization of the understanding as original apperception, Kant aims at establishing it as a faculty of thinking that, on behalf of human cognition, grounds its own domain and the domain of the faculty of sensibility. In Kant's words, this unity of thinking accounts for "[...] the transcendental unity of self-consciousness in order to designate the possibility of a priori cognition from it" ( $K r V$ B132).

Thus, the B-Deduction argument begins with a pre-epistemological approach of the faculty of understanding in order to ensure, within the sphere of human cognition, both the distinctiveness of sensibility and understanding and the determination of the former by the latter.

Kant ensures that, in order to handle this task, one must start by attending to the following propositions:

i) The I think must be able to accompany all my representations.

ii) For otherwise something would be represented in me that could not be thought at all, which is as much as to say that the representation would be nothing for me (from i)).

iii) That representation that can be given prior to all thinking is called intuition.

iv) Thus all manifold of intuition has a necessary relation to the $I$ think in the same subject in which this manifold is to be encountered (from ii) and iii)) ( $\mathrm{KrV}$ B131-132). 
The modalization offered in propositions i) and iii)—i.e., "must be able" and "can be given"- aims precisely at safeguarding the self-sufficiency of understanding and sensibility. Thus, regarding what is thought and what is sensibly given, no foundation in terms of origin or derivation is carried out. ${ }^{5}$

Therefore, Kant's equivalent statements that the I think may not accompany a representation of the self and that intuition, as a representation of the self, may be given before an act of thinking, only and precisely mean that this representation alone would be nothing for the self with regard to cognition. ${ }^{6}$

Proposition iv) could be taken as a confirmation that, already in $\S 16$, Kant is ensuring a necessary relation between sensibility and understanding. Nevertheless, one cannot forget that this proposition relies upon two modalized propositions. Accordingly, looking for this necessary relation in proposition iv) would imply that at least one of the modalizations in propositions i) and iii) is called off. That is to say, in order to grasp that what is sensibly given is related to what belongs to an act of thinking, one would have to assume that the self's act of thinking is, in fact, accompanying everything that is sensibly given or, correlatively, that everything that is sensibly given is originated in this act of thinking.

Here, it is enough to say that Kant's central thesis of an original distinctiveness between the two stems of human cognition dismisses both these possibilities. Thus, the proposition "all manifold of intuition has a necessary relation to the I think in the same subject in which this manifold is to be encountered" only means that, if a manifold of representations is given to this subject, then it is accompanied by an act of thinking which provides consciousness of the unity of its representations.

In this proposition, Kant is not handling further the discussions on that and how a manifold of representations is given to the subject. In a word,

\footnotetext{
${ }^{5}$ It is worth taking into account that this modalization, in the description of the spontaneity of thought as well as of the receptivity of sensibility, grants that what is at stake in the first part of the B-Deduction argument is not a manifold already united in its representations. Accordingly, here is a point of disagreement with Henrich in what regards his well-known thesis that, up to $\$ 20$, Kant “[...] established that intuitions are subject to the categories insofar as they, as intuitions, already possess unity" (Henrich 1969: 645).

${ }^{6}$ Allison overlooks this feature of Kant's argumentation in his commentary that "[...] it is somewhat surprising that Kant begins the section [§16] with a reflection on the conditions of the possibility of intuition" (2015: 349).
} 
Kant's goal is to justify a necessary relation between the unity of a possible manifold of representations and the unity of consciousness of the subject: "[...] the manifold representations that are given in a certain intuition would not all together be $m y$ representations if they did not all together belong to a self-consciousness" $(\mathrm{KrV} \mathrm{B} 132){ }^{7}$

Now, considering that and how a manifold of representation is given as united respectively accounts for an epistemological justification of the understanding in itself as well as in its relation to sensibility.

Kant's account that a manifold of representations is given as united by the faculty of the understanding is an important and challenging moment of his argumentation. The crucial point here is the demonstration that the understanding, which is as a faculty of thinking, can actually provide, in its own domain, the synthesis of what is given as manifold in every representation presiding over cognition. ${ }^{8}$ Therefore, in this first account, what is amenable to proof is that any manifold of representations that is given to the subject as objectively united rely on pure concepts of the understanding.

In approaching this first account, one must follow what Kant now presents as an "explanation of the categories": "[t]hey are concepts of an object in general, by means of which its intuition is regarded as determined with regard to one of the logical functions for judgments" $(K r V \mathrm{~B} 128)$. In this explanation [Erklärung], Kant is emphasizing that the categories ensure the determination of intuition's manifold (i.e., any manifold of representations

\footnotetext{
${ }^{7}$ It is worthwhile mentioning that, in working towards this goal, Kant is taken on the results of $\S 15$. In it, Kant considers "[...] the possibility of a combination in general" and advances a regressive argumentation asserting that i) "[t]he manifold of representations [, which] can be given in an intuition that is merely sensible, i.e., nothing but receptivity" implies (ii.) the understanding activity of synthesis, this due to the fact that combination "[...] is an act of the spontaneity of the power of representation" and that iii) the understanding activity of synthesis-i.e., "[...] the combination (conjunctio) of a manifold in general" - “[...] carries with it the concept of the unity of the manifold". Kant states that the unity of the manifold is provided neither by the receptivity of sensibility nor by the understating activity of synthesis (combination). Thus, it is necessary to "[...] seek this unity [...] someplace higher, namely in that which itself contains the ground of the unity of different concepts in judgments, and hence of the possibility of the understanding, even in its logical use". In short, Kant is emphasizing that the unity of a manifold of representation - being the latter sensibly given and the former implied in the understanding's activity of synthesis - could only be so on account of the subject's consciousness own unity. It is this original unity of the self-i.e., original apperception - that, from $\S 16$ on, will be justified as the original condition of possibility of the categorical synthesis of the sensible manifold (all fragments in $K r V$ B129-131).

${ }^{8}$ Accordingly, the first part of the B-Deduction argument ( $\left.\$ 15-\S 20\right)$ aims precisely at justifying a wellknown claim from $\S 10$ : "[t]he same function that gives unity to the different representations in a judgment also gives unity to the mere synthesis of different representations in an intuition" ( $\mathrm{KrV}$ A79/B104-105).
} 
given to the subject on behalf of cognition) as necessarily grounded upon the unity of representations that is given by the understanding as a faculty of thinking or judging.

The account that a manifold of representations in a given intuition is necessarily subjected to the categories is provided by Kant in $\S 15-\S 20$ of the B-Deduction argument. In this part of the B-Deduction, Kant develops an analytical-regressive analysis of the domain of the faculty of the understanding.

In order to grasp what Kant was getting at in this part of the argument, it is essential that one attends to his outline provided in $\S 20$ :

i) The unity of a given intuition in general, as a necessary outcome of the understanding's activity of synthesis, is only possible due to apperception's original synthesis. Therefore, any sensible intuition given to the subject is necessarily under the unity of apperception $(\S 15-\S 17) ;{ }^{9}$

ii) "The transcendental unity of apperception is that unity through which all of the manifold given in an intuition is united in a concept of the object" (KrV B139, §18);

iii) The necessary subordination of a manifold of representations to the apperception amounts to the logical function of judgments. For "[...] a judgment is nothing other than the way to bring given cognitions to the objective unity of apperception" $(K r V \mathrm{~B} 141, \S 19) ;{ }^{10}$

\footnotetext{
${ }^{9}$ It is worth taking into account that, in the first part of the B-Deduction argument, Kant takes the expression 'sensible intuition' merely as a manifold of representations that is given to and not by the faculty of the understanding. As he puts it: " $[t]$ he pure concepts of the understanding are related through the mere understanding to objects of intuition in general, without it being determined whether this intuition is our own or some other but still sensible one" ( $K r V \mathrm{~B} 150)$.

${ }^{10}$ One can find, within Kant's corpus, other definitions of 'judgment' similar to this one that is given in the B-Deduction:

i) "The unification of representations in a consciousness is judgment" (Prol, AA 04: 304).

ii) "A judgment is the representation of the unity of the consciousness of various representations, or the representation of their relation insofar as they constitute a concept" $(V-\log$, AA 09: 156).

iii) "A judgment is the representation of the way that concepts belong to one consciousness universally [and] objectively" ( $V$-Log, AA 24: 928).

iv) "The representation of the way in which different concepts (as such)* belong to one consciousness** (in general (not merely mine)) is the judgment. They belong to one consciousness partly in accordance with laws of the imagination, thus subjectively, or of the understanding, i.e., objectively valid for every being that has understanding. The subjective connection pertains to the particular situation of the subject in experience. * (universally necessary (empirical or a priori)) ** (Later addition: Concepts belong to one consciousness only insofar as they are conceived under one another, not next to one another (like sensations).)" (Refl 3051, AA 16: 633, quoted in Longuenesse 2000: 88-89).
} 
iv) Categories are correlated to the logical functions of judgment. This is due to the fact that, within the domain of the understanding, the former "[...] are only rules for an understanding whose entire capacity consists in thinking, i.e., in the action of bringing the synthesis of the manifold that is given to it in intuition from elsewhere to the unity of apperception" ( $\mathrm{KrV}$ $\mathrm{B} 145, \S 20) ;{ }^{11}$

v) "All sensible intuitions stand under the categories, as conditions under which alone their manifold can come together in one consciousness" (Thesis of the first part of the B-Deduction) $(K r V \mathrm{~B} 143) .{ }^{12}$

We are now in a position to summarize Kant's argumentation within $\S 15-\S 20$ of the B-Deduction. Kant's first relevant assertion is that categories, in their activity of synthesis, necessarily call upon a given manifold of representations (a sensible intuition in general) and the unity of consciousness. His second noteworthy assertion is that the correlation of categories with the logical functions of judgment presides over a necessary and objective determination of that manifold by the unity of consciousness so that it can become cognition to the subject.

In taking root of the B-Deduction argument with an analytical approach of the understanding's own domain, Kant provides three important results: i) the self-sufficiency of the sensible and intellectual domains of human cognition is preserved; ii) the understanding's characterization as an active and determining faculty is ensured; iii) the possibility of accomplishing the task of the deduction, by means of a demonstration of the necessary relation between the understanding and sensibility, is raised. Let us take into account, in the following section, this last result.

4. The sensible unity of intuition: rendering the relation of the understanding to sensibility

Two features of the first part of the B-Deduction argument allow Kant to cope with the relation of sensibility and understanding in its second part. One is the establishment of the unity of consciousness as the principle upon which any representation aiming at cognition (whether an intuition or a concept)

\footnotetext{
${ }^{11}$ Although this passage is from $\S 21$, it explains Kant's account in $\$ 20$ that "[...] the categories are nothing other than these very functions for judging" ( $\mathrm{KrV} \mathrm{B} 143)$.

12 This sentence is the heading of $\S 20$.
} 
must rely. It is worthwhile mentioning that this feature is set as a preepistemological one but as a necessary epistemological presupposition. The other feature is the account that, from the unity of consciousness, it is possible to justify the unity of a given manifold of representations (an intuition in general) without yet counting on sensibility. ${ }^{13}$

Accordingly, in the second part of the B-Deduction, Kant takes on the premises that any unity of representations implies the unity of consciousness and that the former (as intuition) is necessarily synthesized by categories according to the latter, in order to become cognition. Now, rendering the relation of understanding and sensibility requires showing that this activity of synthesis is operative within the domain of human intuition.

In the Anmerkung provided in $\S 21$, Kant emphasizes that the achievement of the task of the deduction requires demonstrating the relation at issue. According to him, in the assertion that follows from the two abovementioned premises of the first part of the argument, i.e., "[a] manifold that is contained in an intuition that I call mine is represented as belonging to the necessary unity of self-consciousness through the synthesis of the understanding, and this takes place by means of the category", only "[...] the beginning of a deduction of the pure concepts of the understanding has been made, $[\ldots]$ since the categories arise independently from sensibility merely in the understanding" ( $\mathrm{KrV}$ B144). What is still lacking is "[...] the explanation of the a priori validity of the categories in regard to all objects of our senses" (KrV B145). With this, Kant claims, "[...] the aim of the deduction will first be fully attained" $(K r V \mathrm{~B} 145)$.

In attending to the domain of human sensibility in the second part of the B-Deduction, Kant characterizes the argument as an epistemological justification of the relation of this faculty with the understanding. As he states: "[...] for us, thinking of an object in general through a pure concept of the understanding can become cognition only insofar as this concept is related to objects of the senses" (KrV B146).

Moreover, he observes that "for us" human beings, "[s]ensible intuition is either pure intuition (space and time) or empirical intuition of that

\footnotetext{
${ }^{13}$ Kant points out these two features in a letter to Beck from 1792: "I wanted to present the categories themselves as concepts that make it possible to think of objects in general (be the intuition of whatever form it will), and then I wanted also to determine their extension beyond the boundaries of sense, an extension which however yields no cognition" (Br, AA 11: 314).
} 
which, through sensation, is immediately represented as real in space and time" (KrV B146-147). In brief, the consideration of how a manifold of representations is given is at issue. These two ways in which human sensibility is presented are now the elements to be considered in the demonstration of how all human sensible intuition is necessarily determined by the categories.

In $\S 24$, Kant explains how pure intuitions of human sensibility are determined by the categories. In order to do so, he advances a consideration of space and time as pure forms of intuition. Kant credits this step of his argumentation, within the second part of the B-Deduction, to the transcendental synthesis of imagination, which he names synthesis speciosa.

Kant aims at justifying that this synthesis accounts for the transcendental determination of space and time as pure forms of intuition and that this synthesis is correlated to the a priori synthesis performed by the categories, i.e., synthesis intellectualis.

Kant begins by pointing out that, with regard to "[...] the ground of the possibility of cognition a priori", "[...] in us [human beings] a certain form lies at the ground of sensible intuition a priori, a form that rests on the receptivity of the capacity for representation (sensibility)" ( $K r V \mathrm{~B} 150$, a. trans) and presents the "[...] unity of the apperception of the manifold of sensible intuition, the condition under which all objects of our (human) intuition must necessarily stand" ( $K r V \mathrm{~B} 150)$.

This passage presents the relation of what belongs essentially to the understanding, i.e., the discursivity of thought or apperception with that which belongs solely to sensibility, i.e., the giveness under the forms of space and time.

Before proceeding to an explanation of this assertion, one must keep in mind that it holds two dismissed efforts: neither an analysis of the understanding would explain the way in which objects are given to human beings nor an analysis of sensibility would provide the unity of the manifold of representations in it. Accordingly, a method that presents the synthetic $a$ priori relation of spontaneity and receptivity is in need. In $\S 24$, Kant presents the imagination and its activity of synthesis as the element in charge of such a task. 
Kant's most prominent definition of imagination in the B-Deduction is this: "[...] IMAGINATION is the faculty for representing an object even without its presence in intuition" ( $K r V \mathrm{~B} 151)$. In bearing in mind that representations can be given either as intuitions or as concepts, one will notice Kant's hybrid characterization of imagination is this definition. As he puts it:

[...] since all of our intuition is sensible, the imagination, on account of the subjective condition under which alone it can give a corresponding intuition to the concepts of understanding, belongs to sensibility; but insofar as its synthesis is still an exercise of spontaneity, which is determining and not, like sense, merely determinable, and can thus determine the form of sense a priori in accordance with the unity of apperception, the imagination is to this a faculty for determining the sensibility a priori, and its synthesis of intuitions, in accordance with the categories, must be the transcendental synthesis of the imagination, which is an effect of the understanding on sensibility $(\mathrm{Kr} V \mathrm{~B} 151-152)$.

Why is the synthesis of imagination a determinative one? Why is this synthesis provided according to the categories and, thereby, an effect of the understanding on sensibility? Why can imagination determine the form of sensibility according to the unity of apperception?

Now, in answering these questions, one cannot count on the methodology followed in the first part of the B-Deduction, in which Kant presented an analysis of the understanding in its pre-epistemic nature. ${ }^{14}$ It must deal with the domain of what is given to the synthesis of imagination, i.e., the domain of sensibility.

Kant ferrets out an accomplishment in the consideration of the nature of the pure forms of human sensibility. He considers that what is represented as 'determined' in these forms cannot be justified within the sensible domain. For a determination of the manifold cannot at all have its basis in this domain.

As Kant exemplifies, in his consideration of the pure form of time:

$[\ldots]$ inner sense $[\ldots]$ contains the mere form of intuition, but without combination of the manifold in it, and thus it does not yet contain any determinate intuition at all, which is possible only through the consciousness of the determination of the

${ }^{14}$ See Allison (1987: 06): "[...] it does not follow from an analysis of the understanding (or apperception) and the conditions of its unity that the sensible data will conform to these conditions". 
manifold through the transcendental action of the imagination (synthetic influence of the understanding on the inner sense), which I have named the figurative synthesis $\left(\mathrm{KrV}\right.$ B154). ${ }^{15}$

It is in this passage that Kant first provides a justification of the relation of the understanding to sensibility. He notes that the synthesis of the faculty of imagination, in its representation of the forms of human sensibility, provides the proof that the categories necessarily determine the pure intuitions of space and time. In short, pure forms of human sensibility, as a result of the synthesis of the imagination, could only be so due to a 'synthetic influence of the understanding' on sensibility.

What grounds this possibility is Kant's conception of imagination, within the B-Deduction argument, as a faculty that, in what matters to the transcendental justification of human cognition, is necessarily reliant upon the faculty of understanding. That is to say, his conception that "[i]t is one and the same spontaneity that, there under the name of imagination and here under the name of understanding, brings combination into the manifold of intuition" ( $K r V$ B162, footnote).$^{16}$

The last feature of the task of relating the understanding to sensibility is the proof that categories determine also empirical intuitions. In $\S 26$, Kant attends to this feature by considering space and time as pure intuitions of human sensibility.

\footnotetext{
${ }^{15}$ In his letter to Beck from 1792, Kant explains this moment of his argumentation as follows: "I wanted then to make the Deduction of the categories comprehensible by showing its relation to the sensuous forms of space and time, as the conditions of the uniting of these for a possible experience" $(\mathrm{Br}, \mathrm{A} \mathrm{11}$ : 314).

${ }^{16}$ See Caimi (2008: 39): "[i]n the 1781 edition, imagination is presented as an independent faculty: 'There are three original sources (faculties of the soul) which contain the conditions of possibility of every experience, and cannot be derived in turn from any other faculty of the mind; i.e.; sense, imagination and apperception' (A 94). In the second edition, of 1787, imagination is assimilated to understanding, which in this sense remains as the only faculty of spontaneity. The action of imagining, in 1787, 'is an action of the understanding upon sensibility' (B 151-152). Perhaps the most well-known testimony of this shift in Kant's thought regarding imagination is the hand-written correction to his own volume of the first edition, which modifies a passage in A 78: where he had written that imagination is 'a blind function, though indispensable, of the soul', he jotted 'a function of understanding'". Caimi sustains that "[...] the identification of imagination with understanding belongs to a modern conception of imagination, which differs from the traditional conception (Aristotelian and Wolffian) that defines imagination as the faculty of representing in the intuition what is not there (i.e. in intuition)" (2008: 40) and draws the conclusion that "[i]t is the awareness of th[e] independence of sensibility which allows Kant to conjoin the Wolffian conception of imagination to the one we found in Descartes and Spinoza, which distinguishes imagination from understanding only through its object: sensibility" (2008: 49).
} 
Kant points out that, in the first part of the B-Deduction, a 'transcendental deduction' or justification ${ }^{17}$ of the categories within the domain of the understanding implied showing "[...] their possibility as $a$ priori cognitions of objects of an intuition in general" ( $K r V \mathrm{~B} 154)$. He observes, however, that, in order to accomplish the task of the deduction, "[...] the possibility of cognizing a priori through categories whatever objects may come before our senses, not as far as the form of their intuition but rather as far as the laws of their combination are concerned, [...] is to be explained" ( $K r V \mathrm{~B} 154)$.

Accordingly, the accomplishment of the task of the deduction is not restricted either to the domain of the understanding (to the unity of a sensible intuition in general) or to the form of the domain of sensibility (to the representation of the manifold in space and time). Instead, it requires attending to the unity of intuition that amounts to cognition in the domain of sensibility. ${ }^{18}$

\footnotetext{
${ }^{17}$ On the equivalence of 'deduction' and 'justification', see Paton (1965: 313).

${ }^{18}$ The deduction of the categories can, therefore, be accomplished within the B-Deduction argument insofar as the concept of 'unity' approached in its first part-i.e., the unity of sensible intuition - is rendered a concept of the sensible unity of intuition. Thus, Kant's 1787 argument for the categories begins with an element that establishes what is characteristic of the understanding (the unity of sensible intuition) and culminates in an element that, within what is peculiar to the domain of sensibility (the sensible unity of intuition), ensures the legitimate use of these pure concepts of the understanding. I here disagree with Höffe, who, in his evaluation of the argument, states that "[i]t is striking that at no stage does the 'deduction' refer to any individual categories, or even to any specific classes of category, but only to categories in general, to what we might call mere categoriality itself. One might therefore think that Kant is now relativizing [relativiere] his earlier claim to completeness with regard to the table of categories" (2010: 149 - in the English version used here, the German 'relativiere' is translated as 'qualifying'). As he also puts it elsewhere: “[n]owhere in the Transcendental Deduction does Kant discuss the content of the various categories; Fichte's corresponding criticism (Second Introduction to the Science of Knowledge: 'Zweite Einleitung in die Wissenschaftslehre', 6) is correct; Kant's only goal is to demonstrate the objective validity of the categories in general" (Höffe 1994: 75-76). As I have argued, in the B-Deduction, Kant's methodological strategy for achieving the task of the deduction implies establishing the understanding as an active faculty of determination and justifying that it is the only possible ground of what is given as necessarily determined in sensibility. Moreover, he advances this strategy by presenting an element that is characteristic of the understanding and ensuring that, as to the use of its a priori concepts, this element has a correlate in sensibility. In a word, in polarizing the two parts of the deduction task, the concept of 'unity' is set as the beginning and the outcome of the categories' activity of synthesis. Consequently, it is difficult to grasp why and how specifying the categories would be an important matter in any of these two parts that are implied in the task of the deduction. Thus, it seems that what Höffe is seeking in the deduction argument should be sought at another moment of Kant's argumentation-i.e., at the one that is devoted to specifying "[...] the application of the pure concepts of understanding to possible experience" (KrVA160/B199) - , namely, the Analytic of Principles.
} 
Kant's proof that the categories provide the sensible unity of empirical intuitions can be broken down in the following four moments: ${ }^{19}$

[i)] We have forms of outer as well as inner sensible intuition a priori in the representations of space and time, and the synthesis of the apprehension [i.e., the composition of the manifold in an empirical intuition] of the manifold of appearance must always be in agreement with the latter, since it can only occur in accordance with this form $(K r V \mathrm{~B} 160)$.

As the passage clearly indicates, any manifold of representations in the domain of sensibility has the representations of space and time as its ground. This means that, as regards human sensibility, nothing can be represented without first counting on space and time as pure forms.

[ii)] But space and time are represented a priori not merely as forms of sensible intuition, but also as intuitions themselves (which contain a manifold), and thus with the determination of the unity of this manifold in them $(\mathrm{KrV} \mathrm{B} 160)$.

In this second passage, Kant emphasizes that space and time are also given in human sensibility as one space and as one time. Thus, as intuitions that contain a manifold of representations that is determined in its unity (see $K r V$ B161, footnote). ${ }^{20}$ In such a characterization, space and time are defined as formal intuitions or pure intuitions of human sensibility.

[iii)] Thus even unity of the synthesis of the manifold, outside or within us, hence also a combination with which everything that is to be represented as determined in space or time must agree, is already given a priori, along with (not in) these intuitions, as condition of the synthesis of all apprehension ( $\mathrm{KrV} \mathrm{B} 161)$.

\footnotetext{
${ }^{19}$ In discussing these moments, I am following the division proposed by Allison (2015: 194-195).

${ }^{20}$ Kant here notes that "[...] since through it [the synthesis of imagination] (as the understanding determines the sensibility) space or time are first given as intuitions, the unity of this a priori intuition belongs to space and time, and not to the concept of the understanding". Kant's aim, within this moment of the second part of the B-Deduction argument, is precisely the consideration of this unity, now (re)presenting what is receptivity in human sensibility, as necessarily counting upon the activity of discursivity, i.e., the conceptual apparatus of the faculty of understanding.
} 
Unlike the previous passages, Kant is here clearly concerned with what is actually given as cognition in human sensibility. He argues that this 'given' is 'represented as determined in space or time' and implies their unity. Otherwise expressed, everything that is represented according to the pure forms of intuition implies that space and time are themselves unities as intuitions. In brief, the synthesis of representations in empirical intuitions implies the unity that is characteristic of pure intuitions.

[iv)] But this synthetic unity [of apprehension] can be none other than that of the combination of the manifold of a given intuition in general in an original consciousness, in agreement with the categories, only applied to our sensible intuition ( $K r V \mathrm{~B} 161)$.

In this last passage, Kant maintains that the synthesis of apprehension-i.e., the synthesis of the manifold of empirical intuitions, which is necessarily undertaken in the domain of sensibility according to the pure forms of space and time, and implies their unity as pure intuitions - can only be justified from that unity that is characteristic of the domain of the understanding. Accordingly, the synthesis of what is given in sensibility as empirical intuition and amounts to an object of cognition necessarily implies the unity of the consciousness of the subject (the principle upon which an objective determination according to the categories relies). ${ }^{21}$

With this fourth moment, Kant achieves the outcome that empirical intuitions are necessarily under the categories and, therefore, that human

\footnotetext{
${ }^{21}$ It is worth taking into account other two passages in which Kant approaches this issue: i) "Synthetic unity of apperception a priori is the synthesis of the manifold in accordance with an a priori rule. The logical function is the action of unifying the same consciousness with many representations, i.e., of thinking a rule in general. The unity of intuition a priori is only possible through the combination of the manifold in one apperception, which must therefore take place a priori, consequently also the unity of the synthesis of all empirical intuitions, since they are to be encountered in space and time" (Refl 5642, AA 18: 282); ii) "Two sorts of representations are needed for cognition: 1) intuition, by means of which an object is given, 2) concept, by means of which it is thought. To make a single cognition out of these two pieces of cognition a further activity is required: the composition of the manifold given in intuition in conformity with the synthetic unity of consciousness, which is expressed by the concept. Since composition, either through the object or through its representation in intuition, cannot be given but must be produced, it must rest on the pure spontaneity of the understanding in concepts of objects in general (of the composition of the given manifold)" (Letter to Beck, from 1792; Br, AA 11: 315316).
} 
cognition is justified by means of a necessary relation between theoriginally distinct — domains of the understanding and sensibility. ${ }^{22}$

In advancing an argumentation that presents both pure and empirical intuitions under the activity of synthesis provided by the categories and, therefore, endowed with a sensible unity which is only possible due to the performance of these pure concepts of the understanding, Kant accomplishes his aim in the second part of the B-Deduction. In short, the sensible unity of intuition accounts for the relation of the understanding and sensibility.

\section{Concluding remarks}

I have argued that the B-Deduction argument can be methodologically understood as a justification of the necessity of the categories for the unity of sensible intuition - set in the understanding - and its correlate, sensible unity of intuition-presented in sensibility. This means that the argument contends with the two features implied in this justification, i.e., the distinctiveness and the necessary relation of the understanding and sensibility.

In attending to Kant's definition of 'transcendental cognition', it was observed that only in the B-Deduction argument Kant presents an approach presiding over the justification of the categories as pure concepts endowed with legitimate use. Moreover, in addressing this argument's methodology, it was noted that, while the first part of the argument revolves around an analysis of the understanding; its second part calls upon a synthetic methodology relating the understanding to sensibility. Finally, in presenting and discussing the B-Deduction argumentation, it was elucidated that its first part deals with a pre-epistemological justification of the categories' activity of synthesis (the unity of sensible intuition) and its second part is devoted to

\footnotetext{
${ }^{22}$ In a passage from the Fortschritte der Metaphysik, Kant presents a summary of this outcome in what matters to the two parts of the B-Deduction argument: "[k]nowledge is a judgment from which proceeds a concept that has objective reality, i.e., to which a corresponding object can be given in experience. But all experience consists in the intuition of an object, i.e., an immediate and individual representation, through which the object is given as to knowledge, and a concept, i.e., a mediate representation through a characteristic common to many objects, whereby it is therefore thought. Neither of the two types of representation constitutes knowledge on its own, and if there are to be synthetic a priori cognitions, there must also be a priori intuitions as well as concepts, whose possibility must therefore first be discussed, and then their objective reality proved through the necessary use of them, in virtue of the possibility of experience" (FM, AA 20: 266).
} 
explaining that and how this activity is performed in human sensibility in order to provide cognition (the sensible unity of intuition).

If the approach offered in this essay is convincing, it has important implications for the insight into Kant's theoretical philosophy and his effort in the transcendental deduction. With it, one may understand why Kant gave up an argument beginning with an analysis of human cognition as a whole and advanced an argument that starts with an analysis of the understanding's function of unity and ends with a synthetic explanation of the necessary relation of this activity to sensibility's spatiotemporal givenness. This, I suggest, is an essential methodological key for grasping what Kant was getting at in the proof-structure of the B-Deduction argument. ${ }^{23}$

\section{References}

ALLISON, H. E.: "Reflections on the B-Deduction", The Southern Journal of Philosophy 25 (1987) 1-16.

: Kant's transcendental deduction: an analytical-historical commentary, New York, Oxford University Press, 2015.

BAUMANNS, P.: Kants Philosophie der Erkenntnis: durchgehender Kommentar zu den Hauptkapiteln der "Kritik der reinen Vernunft", Würzburg, Königshausen \& Neumann, 1997.

CAIMI, M.: "Comments on the Conception of Imagination in the Critique of Pure Reason", in ROHDEN, V.; TERRA, R. R.; DE ALMEIDA G. A.; RUFFING, M. (eds.): Recht und Frieden in der Philosophie Kants - Akten des X. Internationalen Kant-Kongresses, Berlin/New York, Walter de Gruyter, 2008.

: Kant's B Deduction, Newcastle, Cambridge Scholars Publishing, 2014.

ERDMANN, B.: Beiträge zur Geschichte und Revision des Textes von Kants Kritik der reinen Vernunft, Berlin, G. Reimer, 1900.

HENRICH, D.: "The proof-structure of Kant's transcendental deduction", The Review of Metaphysics 22 (1969) 640-659.

HINSKE, N.: Kants Weg zur Transzendentalphilosophie, Berlin, Kohlhammer, 1970.

\footnotetext{
${ }^{23}$ I would like to express my gratitude to Professor Mario Caimi for his valuable comments and
} suggestions on an earlier version of this paper. 
HÖFFE, O.: Immanuel Kant, Albany, State University of New York Press, 1994.

: Kant's Critique of pure reason: the foundation of modern philosophy, London/New York, Springer, 2010.

KANT, I.: Lectures on logic $[V-L o g]$, trans. YOUNG, J. M., New York, Cambridge University Press, 1992.

: Critique of pure reason $[\mathrm{Kr} V]$, trans. GUYER, P., New York, Cambridge University Press, 1998.

: Correspondence $[\mathrm{Br}]$, trans. ZWEIG, A., New York, Cambridge University Press, 1999.

: Notes and fragments [Refl], trans. BOWMAN, C.; RAUSCHER, F.; GUYER, P., New York, Cambridge University Press, 1999.

: Prolegomena to any future metaphysics that will be able to come forward as science [Prol], trans. HATFIELD, G., New York, Cambridge University Press, 2002.

: What real progress has metaphysics made in Germany since the time of Leibniz and Wolff? [FM], trans. HATFIELD, G., New York, Cambridge University Press, 2002.

LONGUENESSE, B.: Kant and the capacity to judge, Princeton/Oxford, Princeton University Press, 2000.

PATON, H. J.: Kant's metaphysics of experience, New York, Macmillan, 1965. 


\title{
The Principle of the Transcendental Deduction. The First Section of the Deduction of the Pure Concepts of the Understanding
}

\author{
RUdOLF MEER $^{1}$
}

\begin{abstract}
This paper considers the transcendental deduction of the categories from a specific point of view: the First Section of the Deduction of the Pure Concepts of the Understanding. In this passage, Kant not only explores the task and the method of the transcendental deduction in form of the principle of the transcendental deduction but also implements it. The subsequent section(s) of the deduction proceed(s) to build on the argument, and do(es) so in different ways in the A- and the B-deduction. Accordingly, the principle of the transcendental deduction has a crucial function for the entire deduction because it builds a transition between the first and the following section(s) in which Kant constantly refers to it.
\end{abstract}

Keywords: First Section of the Deduction, transcendental deduction, principle of the transcendental deduction, objective deduction, subjective deduction

\section{El principio de la deducción transcendental. La Primera sección de la deducción de los conceptos puros del entendimiento}

\begin{abstract}
Resumen
Este trabajo trata sobre la deducción transcendental de las categorías desde un punto de vista específico: el de la Primera sección de la Deducción de los conceptos puros del entendimiento. En este pasaje, Kant no solo explora función y el método de la deducción transcendental, en la forma del principio de la deducción transcendental, sino que además lo pone en práctica. La(s) siguiente(s) sección(es) de la deducción proceden a desarrollar el argumento y lo hace(n) de maneras diferentes en la deducción A y en la B. De acuerdo con lo anterior, el principio de la deducción transcendental tiene una función crucial con respecto a la propia deducción en sí misma porque construye una transición entre la primera sección y la(s) siguiente(s) en la(s) que Kant hace referencia constantemente a él.
\end{abstract}

Palabras clave: Primera sección de la deducción, deducción transcendental, principio de la deducción transcendental, deducción objetiva, deducción subjetiva

\footnotetext{
${ }^{1}$ Immanuel Kant Baltic Federal University. Contact: rmeer@kantiana.ru.
} 
If you miss the first button-hole, you will not succeed in buttoning up your coat.

(Goethe 1906: 138)

The First Section of the Deduction of the Pure Concepts of the Understanding, ${ }^{2}$ taken in its whole range and significance, offers new insights and allows the understanding and reconstruction of the entire proof. In his maxim, Goethe points out metaphorically the utmost importance of the beginning, which is the principle of the transcendental deduction in $\S 14 .^{3}$

The thesis of the paper is that the First Section constitutes the central argument of the deduction; therein Kant not only explores the task and the method of the transcendental deduction in form of the principle of the transcendental deduction but also implements it. The subsequent section(s) of the deduction proceed(s) to build on the argument, and do(es) so in different ways in the A- and the B-deduction. ${ }^{4}$ In order to prove this thesis, I will argue in four steps.

First, I will demonstrate in the form of a text-immanent analysis of $\S$ 14 that Kant introduces the principle as a syllogism. Although Kant's crucial point in developing the principle is merely a disambiguation of the term experience, it has particular significance because it brings together the Transcendental Aesthetic and the Clue to the Discovery. ${ }^{5}$

\footnotetext{
${ }^{2}$ The Critique of Pure Reason is quoted according to the edition by Paul Guyer and Allen W. Wood with the usual $\mathrm{A} / \mathrm{B}$ pagination. References to other translations are emphasized explicitly. For all references to the Akademie Edition, the usual German abbreviations are used.

${ }^{3}$ The numbering of the text sections is a renewal in the edition of 1787 . However, in the following discussion, I will refer to it to facilitate the orientation in the text.

${ }^{4}$ In contrast to this position, Klemme regards the First Section only as exposure to the principle of the deduction (1996: 149). From Allison's point of view, the First Section is just an "introductory section" that is "intended to explain to the reader the nature and purpose of a transcendental deduction in general" (2015: 165). Furthermore, Carl detects therein merely a methodological introduction (1992: 111, 43-44). With regard to the First Section Guyer claims that it would be "redundant if that is all that it [the transcendental deduction] is supposed to show" (2010: 121). These authors stand in an interpretational tradition with philosophers like Riehl who speaks of a "critical hypothesis" (1876: 373; German: "kritischen Hypothese"), Grayeff who says that it is just a "reader-friendly exposition" (1951: 69, 114; German: "leserfreundliche Exposition"), and Paton (1936: 313-356).

${ }^{5}$ This is in contrast to theories which claim that the entire deduction is based on the principle of the apperception (Caimi 2017: 378-400), the identity of self-consciousness (Henrich 1988: 39-70; Ritzel 1981: 147-149), or the original synthetic unity of apperception (Hoffmann 2004: 60; in a different way Thöle 1981: 312). Even if the deduction is not unfolded from this highest point of the transcendental philosophy, this does not mean that the argumentation does not follow a unified structure, as, for example, Allison (2015: 388) argues.
} 
Second, I will highlight that Kant introduces the principle of the transcendental deduction at the end of $§ 14$. This means that Kant implements the principle right after pages 92-93 of the edition from Johann Friedrich Hartknoch (1781), that is, directly following the so-called objective deduction, as Kant characterizes this passage in the Preface ( $\mathrm{KrV}$ AXVII). ${ }^{6}$ Even though the principle summarizes the argument from pages 92-93, it can be regarded as a transition between the first and the following section(s) and builds, therefore, a transition between the objective and the subjective deduction.

Third, I will pay particular attention to the term principle. In this specific case, Kant borrows the concept from a tradition in rhetoric in which a principium is namely an introduction to a speech but outlining the entire talk subject matter. In this sense, the principle of the transcendental deduction in the First Section also anticipates the entire deduction and solves the question of the deduction that is raised. ${ }^{7}$

Fourth, I will show exemplarily that Kant repeats in the Second and Third Section of the A-deduction, and in the Second Section of the Bdeduction, the principle of the transcendental deduction. In doing so, he firstly repeats the objective deduction, and secondly executes it in the form of a subjective deduction. However, the considerations of the subjective deduction outline the how of the previously developed objective deduction, ${ }^{8}$ and always depend on the chief question which already demonstrated the validity of the concepts a priori. Thus, both sides of the deduction executed

\footnotetext{
${ }^{6}$ That the First Section includes the objective deduction of the concepts of the understanding is a point of view which is shared with Allison (2015: 193), Baum (1986: 12, 64), Baumanns (1997: 399), and Hossenfelder (1978: 9-10).

${ }^{7}$ This interpretation appears to contradict Allison, who sees in the principle of the deduction merely a rhetorical question (2015: 193; see also Guyer 2010: 121). Carl and Baum argue that the objective deduction requires objective experience whereas the subjective one justifies it without this condition (Baum 1986: 73; 1995: 373-392; Carl 1992: 51-52).

${ }^{8}$ Schematically sketched, two basic positions can be distinguished (Moledo 2015: 418-420): the thesis of difference and the thesis of method. Within the scope of the first, it is asserted that both deductions have different tasks. Thereby, the objective deduction justifies that the categories have objective validity, and the subjective deduction shows the how of the relation between the categories and the objects (Henrich 1969: 640-659; Förster 1998: 44). Within the scope of the thesis of method, it is asserted that the differentiation between both deductions concerns only the way in which they justify the objective validity of the categories. Thereby, the objective deduction is based on experience and justifies the objective validity regressively; whereas the subjective deduction justifies the objective validity with regard to the $I$ or rather the unity of apperception (Carl 1992: 51-52; Baum 1986: 73-74).
} 
in the passages following the First Section relate to the principle of the transcendental deduction. ${ }^{9}$

\section{The Principle of the Transcendental Deduction}

In the title Transition to the Transcendental Deduction of the Categories, Kant already indicates the claim of this section, which he numbers in the second edition as paragraph 14. Transition, or in German Übergang, connotes an overlap area as well as an intersection. As this term suggests, the proof in this argument brings together different results of the Critique of Pure Reason - that is, the Transcendental Aesthetic and the Clue to the Discovery of all Pure Concepts of the Understanding. On this basis, Kant presents the principle of the transcendental deduction for the following analysis. With this principle, he clarifies what is "not so easily seen" ( $\mathrm{KrV}$ A90/B123), namely "how subjective conditions of thinking should have objective validity" ( $K r V$ A89/B122). In this way, the principle forms the beginning - the origin, or the basis of - the transcendental deduction in both editions of the Critique of Pure Reason. It introduces a schema "toward which the entire investigation must be directed" (KrV A94/B126).

In paragraph 14, Kant argues in the form of a logical corollary in which he assumes a correspondence-theory of truth. The corresponding relationship of the synthetic representation (A) and the object (B) can be twofold: "Either if the object alone makes the representation possible, or if the representation alone makes the object possible" ( $K r V$ A 92/B 124-5; Prol., 4: 319; Briefe, 10: 130).

If the object makes the representation possible $(\mathrm{B} \rightarrow \mathrm{A})$, as is the case with sensations ( $K r V$ A92/B125, A19-20/B34), the representation is merely passive and receptive. It arises only through the affection of the senses ( $K r V$ A20/B34), and therefore the representation has merely empirical but never a priori character. For such an empirical concept, there is no need for a

\footnotetext{
${ }^{9}$ This is in contrast to Baum, who considers the entire Second Section in the B-deduction to be a subjective deduction, but also in contrast to positions that identify the first step of the deduction (from $\S 15$ to $\$ 20$ ) as an objective deduction, and the second step (from $\$ 21$ to $\$ 27$ ) as a subjective deduction (Henrich 1973: 93; Paton 1936: 241, 501, 527). Furthermore, this is argued against Carl who sees in the Second and Third Section of the A-deduction merely a subjective deduction, and in the Second Section of the B-deduction just an objective deduction (1992: 42-54). But it is also no solution to dismiss the subjective deduction as Strawson (1966: 88) and other interpreters (Hartnack 1967: 47) have done.
} 
transcendental deduction but rather an empirical one "which shows how a concept is acquired through experience and reflection on it" (KrV A85/B117). But if the representation is the cause of the object $(\mathrm{A} \rightarrow \mathrm{B})$, it precedes any empirical knowledge. In this way, the representation can be a priori determined in respect of the object. The conformity of the object with the representation understood as cause makes it possible, as Kant emphasizes, "to cognize something as an object" (KrV A92/B125). For such a representation, however, a transcendental deduction is necessary, because proofs from experience are not sufficient for its lawfulness. For this reason, the "way in which concepts can relate to objects a priori" ( $K r V$ A85/B117) must be explained separately ( $K r V \mathrm{~B} 167)$.

Regarding the disjunction of representation (A) and object (B), it has to be pointed out that (A) does not produce (B) "as far as its existence is concerned" ( $\mathrm{KrV}$ A92/B125). Accordingly, the representation is not the cause of things (Refl 20: 130) but forms the conditions "to cognize something as an object" ( $\mathrm{KrV}$ A92/B125, A95), which Kant highlights in boldface type. ${ }^{10}$ For this reason, there are two conditions which make a cognition of an object possible: "first, intuition, through which it is given, but only as appearance; second, concept, through which an object is thought that corresponds to this intuition" (KrV A 92/B 125, A19/B33, A50/B74). Even before the actual execution of the quid juris question, Kant assumes that a representation-as a condition of the possibility of all objects - includes two sides: intuition and concept. Thus, he presumes, like the jurists, that the quid facti question has already been clarified before answering the quid juris question. He introduces this assumption by referring in paragraph 13 to the Transcendental Aesthetic and the Clue to the Discovery of all Pure Concepts of the Understanding ( $K r V$ A85/B118). It is therefore clear that the categories, complementary to the forms of intuition, are part of the possibility of objects, and that the following explication of the two conditions questions only their lawfulness, or in other words, the reason for the certainty of the truth of our cognition (Baum 1986: 65).

The first conditions are the forms of intuition - space and timewhich "lie in the mind a priori as the ground of the form of objects"

\footnotetext{
${ }^{10}$ Kant distinguishes precisely between a case in which a representation makes an object possible by virtue of being a cause of the object, and a case in which it makes an object possible by virtue of making it possible for it to be thought (Longuenesse 1998: 20-26).
} 
( $K r V$ A93/B125) and determine the form of the appearances. Thus, it can be conceptualized "with little effort" (KrV A89/B121) that all appearances must necessarily agree with these formal conditions of sensibility in order to appear at all and "be empirically intuited and given" ( $K r V$ A93/B125). For this reason, there is no need for deduction, because geometry "follows its secure course through strictly a priori cognitions without having to beg philosophy for any certification of the pure and lawful pedigree of its fundamental concept of space" ( $\mathrm{KrV}$ A87/B119, A24/B38). Solely on the basis of the specific nature of the concepts of the understanding-whose objective validity cannot be proved by an object of experience because of the distinction between form and matter ( $K r V$ A89/B122) _ " arises the unavoidable need to search for the transcendental deduction not only of them [the categories] but also of space" ( $\mathrm{KrV}$ A88/B120).

In a self-reflective passage, which Kant introduces with the formulation "[t] he question now is whether" $\left(\mathrm{KrV}\right.$ A93/B125), ${ }^{11}$ he develops, based on the first condition, an analogous argument for the second condition: in this self-inquiry Kant deals with the question of whether, in addition to the forms of intuition, there are also a priori concepts which form conditions "under which alone something can be, if not intuited, nevertheless thought as object in general" ( $K r V$ A93/B125). This question has far-reaching consequences following Kant's characterization of its status because a positive answer means that all empirical conditions of the objects must stand under such concepts.

A central focus of the argument turns on two preliminary conceptual decisions by Kant: on the one hand, he differentiates between empirical intuition and cognition - a distinction which has already been introducedby referring to the concept of experience: experience is introduced as a combination of intuitions and concepts. It forms a cognition because it contains, in addition to given intuitions, "a concept of an object" (KrV A93/B126). ${ }^{12}$ On the other hand, Kant deals specifically with the concept of the transcendental deduction ( $K r V$ A85/B117): if the "objective

\footnotetext{
${ }^{11}$ See also the letter to M. Herz: "ich frug mich nämlich selbst: auf welchem Grunde beruht die Beziehung desjenigen, was man in uns Vorstellung nennt, auf den Gegenstand?" (Briefe, 10: 130) With this question Kant detected the necessity of a "Critick der reinen Vernunft" (Briefe, 10: 130) and abandoned his project from "Grentzen der Sinnlichkeit und der Vernunft" (Briefe, 10: 130; see also Longuenesse 1998: 18-28; Pollok 2009: 326).

12 "Thinking is the action of relating given intuitions to an object" (KrV B304).
} 
validity of the categories, as a priori concepts" ( $K r V$ A93/B126), should be proved, it "rests on the fact that through them alone is experience possible (as far as the form of thinking is concerned)" ( $K r V$ A93/B126). Thus, the transcendental deduction is defined as an explanation of the possibility that the categories refer a priori to objects. Hence, the quid juris question is developed and answered if the categories are recognized as conditions of the possibility of experience. They are conditions of the possibility of experience, if "only by means of them can any object of experience be thought at all" ( $K r V$ A93/B126).

On the basis of these preliminary considerations and the nominal definition of experience, Kant develops the proof as follows: because all experience, in addition to intuition of the senses, requires a concept of an object, "hence concepts of objects in general lie at the ground of all experiential cognition as a priori conditions" ( $K r V$ A93/B126). For this reason, experience not only depends on the formal conditions of sensibility but also on the formal conditions a priori, which are valid for the thinking of objects. Thus, the above-mentioned second condition is proved.

Kant's argument can, therefore, be reconstructed as follows:

Major premise: If $\mathrm{A}$, then $\mathrm{B}$.

Minor premise: It is the case that A.

Conclusion: It is the case that $\mathrm{B}$.

Although Kant does not formulate the first premise explicitly, it can be derived from the question formulated in the self-reflection. Thus, the argument can thus be formalized as follows:

\footnotetext{
Major premise: If all experience contains, in addition to the forms of intuition, concepts a priori of an object, then the concepts of objects in general lie at the ground of all experiential cognition as a priori conditions.

Minor premise: "Now, however, all experience contains in addition to the intuition of the senses [...] a concept of an object" (KrV A93/B126).

Conclusion: "[H]ence concepts of objects in general lie at the ground of all experiential cognition as a priori conditions" ( $\mathrm{KrV}$ A93/B126).
} 
On the basis of this conclusion, Kant gains in the following passage of the Transition to the Transcendental Deduction the principle of the transcendental deduction of all a priori concepts. Thus, the principle of the deduction gives an answer to the question how subjective conditions can have objective validity. The explained answer is as simple as possible but as secure as necessary: this principle states that the concepts a priori "must be recognized as a priori conditions of the possibility of experiences (whether of the intuition that is encountered in them, or of the thinking)" ( $K r V$ A94/B126). As conditions of the possibility of experience, these concepts have objective validity and they are necessary. The proof of their objective validity correlates with the objective validity of the intuitions, indicated by Kant's formulation in brackets in the course of the explication of the principle. Thus, Kant refers once more to the passage A88/B121, in which the deduction of the forms of intuition was linked with the deduction of the concepts of the understanding.

\section{Objective and Subjective Deduction}

Because of Kant's claim in the Preface of the first edition of the Critique of Pure Reason that the objective deduction of the categories has been effected in the above-reconstructed Transition to the Transcendental Deduction, special attention should be paid to this passage. He notes in the form of $a$ reminder to the reader, that even if the "subjective deduction does not produce the complete conviction that I expect the objective deduction that is my primary concern would come into its full strength, on which what is said at pages 92-93 should even be sufficient by itself" (KrV AXVII). The reference to pages 92-93 indicates the first two paragraphs in the Transition to the Transcendental Deduction.

Therefore, with regard to "the investigations" ( $K r V$ AXVI), which he has undertaken "under the title Deduction of the Pure Concepts of the Understanding" ( $\mathrm{KrV}$ AXVII), Kant distinguishes two sides in the Preface of the first edition of the Critique of Pure Reason, that is, the inquiry which "goes rather deep" ( $\mathrm{KrV}$ A XVII), consists of an objective and a subjective deduction.

The objective deduction asks "[w]hat and how much can understanding and reason cognize free of all experience?" ( $K r V \mathrm{AXVII})$. 
Thus, it has to "demonstrate and make comprehensible" ( $\mathrm{rrV}$ AXVI) the objective validity of the concepts a priori. It is demonstrated if the validity of the concepts becomes evident, but it is only comprehensible if it is proved. The principle of the deduction, as explored in paragraph 14, achieves both of these. It shows that experience is just possible with regard to the categories.

A subjective deduction, however, asks, "[h]ow is the faculty of thinking itself possible?" (KrV AXVII), and focuses on the "pure understanding itself" ( $K r V$ AXVII), on its "possibilities and the powers of cognition" (KrV AXVII). The context, which must be given if the categories claim objective validity, is thus investigated. However, the subjective deduction is a declaration to explore the already proven relation. It shows the subjective possibility of the relation of categories with reference to the recognizing subject. Thus, the objective deduction is adjudged to clarify the question if (or that), and the subjective deduction was adjudged to clarify how, the categories relate to the manifoldness in time and space.

Based on this distinction, ${ }^{13}$ as Kant emphasizes, the objective deduction builds the so-called "chief question" ( $K r V$ AXVII) of the Deduction of the Pure Concepts of the Understanding, although such an objective deduction always requires a subjective one.

\begin{abstract}
Since the latter question [How is the faculty of thinking itself possible?] is something like the search for the cause of a given effect, and is therefore something like a hypothesis (although, as I will elsewhere take the opportunity to show, this is not in fact how matters stand), it appears as if I am taking the liberty in this case of expressing an opinion, and that the reader might therefore be free to hold another opinion ( $\mathrm{KrV}$ AXVII).
\end{abstract}

In this quotation from the Preface, Kant explores why the subjective deduction is subordinated under the objective one. ${ }^{14}$ The primary reason is that, in the context of the subjective deduction, he uses the psychological

\footnotetext{
${ }^{13}$ This passage of the Preface of the A-edition contradicts the so-called thesis of method concerning the distinction between the subjective and the objective deduction (see footnote 4). For this reason, the text follows the so-called thesis of difference. Based on this decision, the central question in the current research debate treats the relevance of the subjective deduction as a psychological investigation of the activity of our capacity. The fourth part of this paper will develop how the subjective deduction depends on the objective one.

${ }^{14}$ Of course, the Preface is a preface for the whole Critique and not only for the transcendental deduction (Allison 2015: 199) but that does not soften the judgment.
} 
terms of two famous men, John Locke and David Hume, which becomes especially evident in the revised and extended version of paragraph 14 . However, he decisively rejects the claims of both predecessors, the one leading to "enthusiasm" ( $K r V \mathrm{~B} 128)$ and the other to "skepticism" $(K r V \mathrm{~B} 128)$. Kant attempts rather to "steer human reason between these two cliffs" (B128). By prefixing the principle from the Transition to the Transcendental Deduction to such psychological examinations, Kant aligns the investigation to the subjective sources. In this sense, the subjective deduction is just a search for the cause of a solution already given in the objective deduction of the First Section. It is the principle of the Transition to the Transcendental Deduction which allows Kant to develop the subjective sources "like a hypothesis" ( $K r V$ AXVII). It is the great importance attached to the objective deduction which allows him to promise that he will show elsewhere that "this is not in fact how matters stand" ( $K r V$ AXVII) with the subjective deduction. What is not clear is if he really does do this anywhere else. $^{15}$

Regarding this exposition, however, it must be emphasized that the Preface of the first edition of the Critique of Pure Reason only arose after Kant had put the three sections of the A-deduction on paper (Erdmann 1878: 24; Düsing 2000: 139-140). In addition, Kant dropped this distinction in the second edition of the Critique of Pure Reason. Consequently, it is not clear that the distinction between subjective and objective deduction introduced in the Preface of the A-edition was the basis for the execution of the deduction. These issues raise an enormously complex research question with regard to the differentiation within the framework of the Transcendental Analytic.

However, the same distinction is also found in the Second Section of the A-deduction. Here Kant suggests that "it is already a sufficient deduction" ( $\mathrm{KrV}$ A96) of the categories and a "justification of their objective validity if we can prove that by means of them alone an object can be thought" ( $K r V$ A96-7). In addition to such a method of proof, the "subjective sources that comprise the a priori foundations for the possibility of experience" ( $\mathrm{KrV}$ A97) have to be assessed. With this investigation of objective validity and subjective sources, not only is the distinction of the transcendental

\footnotetext{
${ }^{15}$ It is an open question where this argument appears: perhaps in the passage A336/B393 (Moledo 2015: 418-429; Mösenbacher 2016: 85-89).
} 
deduction into a subjective and an objective part repeated with almost the same terms in the Second Section of the A-deduction, but so too is their significance in the examination. In the passage A111, Kant again emphasizes the importance of the "objective validity, which was just what we really wanted to know" (KrV A111).

In the Metaphysical Foundations of Natural Science, ${ }^{16}$ and with regard to the second edition of the Critique of Pure Reason, Kant returns to this distinction, even if he no longer uses the terms objective and subjective deduction in 1786. In an enormous footnote to the Preface, Kant responds to a review by Prof. Ulrich, who had declared that the "principal basis" (MAN, 4: 474) of the Critique of Pure Reason, i.e., the deduction of the categories, is actually obscure. Without "an entirely clear and sufficient deduction of the categories" (MAN, 4: 474), Kant's critic says, "the system of the Critique of Pure Reason totters on its foundation" (MAN, 4: 474). Kant replies to this attack by countering it as follows. The categories are forms of thought that we must use in intellectually dealing with whatever we have to think about. This gives him the core thesis that the categories represent the limits to what thoughts it is possible to have and thus

the question how the categories make such experience possible is important enough for completing the deduction where possible, with respect to the principal end of the system, namely, the determination of the limits of pure reason, it is in no way compulsory, but merely meritorious (MAN, 4: 474).

Thus, Kant again distinguishes between a proof of that or if, as already given in paragraph 14 of the Critique of Pure Reason, and a proof of how the categories make experience possible. Moreover, in the considerations of 1786, he returns once more to the almost equal significance of both examinations.

These arguments in the Metaphysical Foundations of Natural Science are formulated in relation to a rewriting of the transcendental deduction. In this sense, Kant returns in the Preface of the B-edition again to the reproach of the "obscurity in the Deduction of the Concepts of the Understanding"

\footnotetext{
${ }^{16}$ The Metaphysical Foundations of Natural Science is quoted according to the edition by Michael Friedman.
} 
( $K r V$ BXXXVIII) and says that he will make "improvements" ( $K r V$ BXXXVIII) in the "presentation" ( $K r V$ BXXXVIII) of the deduction in this new edition. Even though it concerns far more than mere external modifications of the proof, Kant also refers back, in paragraph 15, to the argumentation of the First Section where he states that the categories already presuppose the connection to the manifold in the sensibility. "The category therefore already presupposes combination" ( $K r V$ B131). Accordingly, the combination is already proven and Kant merely considers the "ground of the unity of different concepts" (KrVB131), which must be found in a fundamental unity - that is, in the unity of the subject. The task for the subsequent section, however, is to search for the "possibility of the understanding" ( $K r V \mathrm{~B} 131)$.

To sum up, in both the Preface and in the Second Section of the transcendental deduction (of both editions), Kant highlights the argument of the objective deduction. It is characterized first as "already [...] sufficient" ( $\mathrm{KrV}$ AXVII) and the second time as "sufficient by itself" ( $\mathrm{Kr} V \mathrm{~A} 96)$. Even though the B-deduction does not refer to this distinction, Kant also uses the distinction in paragraph 15 and classifies its significance in the Metaphysical Foundations of Natural Science in the same way as in the A-deduction. Thus, the objective deduction is sufficient because it necessarily implies the legality, and hence the objective validity, of the categories. With this characterization of the objective deduction, Kant puts the argument in the Transition to the Transcendental Deduction not solely in the Preface but also in both editions of the main text at the core of his deliberations.

\section{The Meaning of Principle}

Based on the investigation in the First Section of the deduction and the distinction between the subjective and objective deduction, it is again possible to ask what Kant means by the term principle.

The term has a wide range of meanings (KrV A300/B356) in the Kantian philosophy. He uses the concept equivalently with the Latin princip or principium and the German Grundsatz. Thus, the term stands for beginning (KrV A652/B680), universal condition ( $K r V$ A305/B361), unconditioned ( $K r V$ A336/B394), and is applied as an empirical, a heuristic, a comparative, a constitutive, a formal, and a logical principle (Meer 2019: 215-221). The 
common feature of all these definitions is that a principle is the cause of something else not in a temporal (initium) but in a systematic way. In this sense, principles are crucial in Kant's system to guarantee the completeness of the system: for example, the completeness of the categories ( $\mathrm{KrV} \mathrm{A} 80$ 81/B106-107), or the cosmological ideas ( $K r V$ A408/B435). The principle of the transcendental deduction, in particular, must be distinguished from Kant's supreme principle of all synthetic judgments (KrV A154/B193), and the principles of reason ( $\mathrm{Kr} V$ A658/B686; see also Longuenesse 1998: 84, 243245; Rescher 2000: 64-70).

Kant uses the term principium in the First Section of the deduction specifically in its Latin sense of introduction (lat. prooemium, principium, exordium). In the German rhetoric of the Modern Era, the exordium is translated mostly as Eingang (initiation). The aim of such initiation is as an aid to the audience, and a way of casting the speech in a favorable light for the intentions of the speaker (Cicero 1890: 325; Gottsched 1737: 89-90). Following Aristotle (1958: 1415b), the exordium is mostly directed to the affecting of the audience and is not geared objectively. In the Early Modern period, the thematic and argumentative function of the initiation is strengthened by supplementation or replacement of the exordium with the propositio (Kositzke 1994: 980). As Weise (1642-1708) declares, the propositio forms the "essence and [the] core of the speech" ["Wesen und den Kern von der Rede"] (1683: 169) wherein "one says what one wants in the speech" [“man sagt, was man in der Rede haben will'] (1683: 169). Lindner (1729-1776), a professor of poetry in Königsberg and well known to Kant (Kühn 2003: 190-193), extends this characterization from Weise by assigning the initiation a logical function in the concept of a speech. The content of the initiation, which precedes the main part (German: Hauptsatz), stands in "relation of the general to the particular" ["Verhältnis des allgemeinen zum besonderen"] (Lindner 1755: 157). With reference to Gottsched, Lindner also emphasizes that the initiation may even consist of a short essay, whose subject "has some affinity with the main part" ["einige Verwandtschaft mit dem Hauptsatze"] (Lindner 1755: 157). ${ }^{17}$

We should read the First Section of the deduction as an initiation (see footnote 4), solely in this specific sense of a propositio, as in the rhetoric of

\footnotetext{
${ }^{17}$ In this sense, Sulzer writes: "Es ist also kaum ein Theil der Rede, an dem man die Größe des Redners besser erkennen kann, als der Eingang" (1771: 24).
} 
the Modern Era. Accordingly, Kant gives in such a propositio, in addition to the content, scope, and methodology, an overview of the central concepts and of the system. Thereby, the principle summarizes the objective deduction in the pages 92-93 and introduces a schema for the following analysis. As Kant writes: the principle of the deduction introduces a schema "toward which the entire investigation must be directed" (KrV A94/B126).

In summary, the First Section constitutes, as the term principle already expresses, a paradigmatic initiation in the procedure of taking evidence. On this understanding, it can clearly be seen how Kant develops the argument beyond the First Section.

\section{Reflection of the Structure of the Deduction}

Kant understands the transcendental deduction in the Critique of Pure Reason as an investigation into the objective validity of the concepts of the understanding, and also as an investigation into their subjective sources. The objective deduction, which Kant explicitly identifies with the Transition to the Transcendental Deduction, forms the chief question within the framework of the Critique of Pure Reason. Based on this fact, the principle of the deduction summarizes this argument and builds a transition to the following analysis, in which it anticipates the entire deduction. In this way, the objective deduction can adequately prove the objective validity of the categories, and the subjective deduction, which clarifies the question how the categories have objective validity, is therefore subordinated.

According to the First Section and, in particular, to the principle of the deduction, Kant has already developed a solution to his transcendental deduction, and the following passages in the A- and B-deduction are supposed to execute it. Kant further develops the argument by way of an investigation into the subjective sources, which is executed with regard to the objective validity of the categories. Hence, the entire Second and Third Section of the A-deduction, as well as the Second Section of the B-deduction, cannot merely be regarded as a subjective deduction. Rather, and with reference to the principle of the deduction, these passages deal with the objective and subjective deduction. For this reason, the two strategies of the argument do not constitute two different proofs, but rather are always connected as "two sides" ( $\mathrm{KrV}$ AXVI) of one proof. 
Despite the prior objective deduction in the First Section, the text does not show a strict separation of the two sides of the deduction. The passages following the First Section outline an investigation of the subjective sources, but one based on a repetition of the already developed objective validity of the concepts of understanding. ${ }^{18}$ Kant returns to the objective deduction in the Second and Third Section of the A-deduction, especially in the passages A98, A104-106, A111, A119, A124-125, and A130. In the Second Section of the B-deduction, he refers to the objective deduction, especially in the passages B130-131, B136-137, B143, B150-151, and B160-161.

\section{Conclusion}

This paper considers the transcendental deduction of the categories from a specific point of view: the First Section of the Deduction of the Pure Concepts of the Understanding. Kant develops the principle of the transcendental deduction in this passage of the Critique of Pure Reason that remains unchanged between the first and second edition. In the Preface of the first edition, he identifies the first two paragraphs of this passage with the objective deduction. The principle summarizes this objective deduction and builds a transition to the following section(s). For this reason, the principle has a fundamental significance for the entire argument in both editions, because already in this passage Kant has achieved the required results of the transcendental deduction, i.e., the objective validity of the concepts of understanding. In subsequent section(s), Kant constantly refers to this principle of the transcendental deduction, referring to it in the context of his consideration of the subjective sources - which should clarify the already proven possibility of this validity in the subjective deduction. For this reason, the present argument points out that it is only possible to understand and reconstruct the entire proof if the principle of the deduction is reconsidered in light of its full importance and scope.

\footnotetext{
${ }^{18}$ Based on the schematic differentiation between the distinction of subjective and objective deduction (see footnote 4), the interpretation follows the thesis of difference. Furthermore, it becomes evident that the subjective deduction is solely possible in the context of the objective one. That means, both deductions answer different questions but the subjective depends on the objective one.
} 
References

ALlisON, H. E.: Kant's Transcendental Deduction. An AnalyticalHistorical Commentary, Oxford, Oxford University Press, 2015.

ARISTOTLE: Ars Rhetorica, ed. ROSS, W. D., Oxford, Oxford University Press, 1958.

BAUM, M.: "Der Aufbau der Deduktion der Kategorien", in FUNKE, G. (ed.): Proceedings of the Sixth International Kant Congress, Pennsylvania, Pennsylvania University Press, 1985.

: Deduktion und Beweis in Kants Transzendentalphilosophie. Untersuchungen zur Kritik der reinen Vernunft, Königstein, Hain, 1986.

: "Über die Kategoriendeduktion in der 1. Auflage der Kritik der reinen Vernunft", in ROBINSON, H. (ed.): Proceedings of the Eight International Kant Congress, Memphis, Marquette University, 1995.

BAUMANNS, P.: Kants Philosophie der Erkenntnis. Durchgehender Kommentar zu den Hauptkapiteln der "Kritik der reinen Vernunft", Würzburg, Königshausen und Neumann, 1997.

CAIMI, M.: "Das Prinzip der Apperzeption und der Aufbau der Beweisführung der Deduktion B”, Kant-Studien 108 (2017) 378-400.

CARL, W.: Die Transzendentale Deduktion der Kategorien in der ersten Auflage der Kritik der reinen Vernunft. Ein Kommentar, Frankfurt am Main, Klostermann, 1992.

CICERO, M. T.: De oratore, Hildesheim, Olms, 1965.

DÜSING, K.: "Apperzeption und Selbstaffektion in Kants Kritik der reinen Vernunft", in FISCHERN, N. (ed.): Kants Grundlegung einer kritischen Metaphysik. Einführung in die Kritik der reinen Vernunft, Hamburg, Meiner, 2000.

ERDMANN, B.: Kants Kriticismus in der ersten und zweiten Auflage der Kritik der reinen Vernunft. Eine historische Untersuchung, Leipzig, Voss, 1878.

FÖRSTER, E.: “Die Vorreden”, in MOHR, G.; WILLASCHEK, M. (eds.): Immanuel Kant. Kritik der reinen Vernunft, Berlin, Akademie Verlag, 1998.

GOETHE, J. W. v.: Maxims and Reflections, New York, The MacMillan Company, 1906. 
GOTTSCHED, J. C.: Ausführliche Redekunst. Nach Anleitung der alten Griechen und Römer wie auch der neueren Ausländer, Leipzig, Breitkopf, 1737.

GRAYEFF, F.: Deutung und Darstellung der theoretischen Philosophie Kants. Ein Kommentar zu den grundlegenden Teilen der Kritik der reinen Vernunft, Hamburg, Meiner, 1951.

HARTNACK, J.: Kant's Theory of Knowledge, New York, Brace and World, 1967.

HENRICH, D.: "The Proof-Structure of Kant's Transcendental Deduction", The Review of Metaphysics 22 (1969) 640-659.

: "Die Identität des Subjekts in der transzendentalen Deduktion", in OBERER, H.; SEEL, G. (eds.): Kant. Analysen - Probleme - Kritik, Würzburg, Königshausen und Neumann, 1988.

HOFFMANN, T. S.: "Kants transzendentale Deduktion der reinen Verstandesbegriffe - Ein Buch mit sieben Siegeln?", in SCHMIDT, K.; STEIGLEDER, K.; MOJSISCH, B. (eds.): Aktualität der Philosophie Kants. Bochumer Ringvorlesung Sommersemester 2004, Amsterdam/Philadelphia, Grüner, 2005.

HOSSENFELDER, M.: Kants Konstitutionstheorie und die Transzendentale Deduktion, Berlin/New York, deGruyter, 1978.

KITCHER, P.: "Kant on Self-Identity”, The Philosophical Review 91 (1982) 41-72.

KANT, I.: Critik der reinen Vernunft, ed. FRIEDRICH, J., Hartknoch, Riga, 1781.

: Critique of Pure Reason, ed. and transl. GUYER, P.; WOOD, A. W., Cambridge, Cambridge University Press, 1999.

: Metaphysical Foundations of Natural Science, ed. and transl. FRIEDMAN, M., Cambridge, Cambridge University Press, 2004.

KEMP SMITH, N.: A Commentary to Kant's Critique of Pure Reason, London, Macmillan, 1918.

KLEMME, H. F.: "Subjektive und objektive Deduktion. Überlegungen zu Wolfgang Carls Interpretation von Kants 'Deduktion der reinen Vernunftbegriffe' in der Fassung von 1781", in BRANDT, R.; STARK, W. (eds.): Autographen, Dokumente und Berichte, Hamburg, Meiner, 1994. 
: Kants Philosophie des Subjekts. Systematische und entwicklungsgeschichtliche Untersuchung zum Verhältnis von Selbstbewusstsein und Selbsterkenntnis, Hamburg, Meiner, 1996.

KOSITZKE, B.: "Einleitung", in UEDING, G. (ed.): Historisches Wörterbuch der Rhetorik, vol. 2., Tübingen, Niemeyer, 1994.

KÜHN, M.: Kant. Eine Biographie, München, Beck, 2003.

LINDNER, J. G.: Anweisung zur guten Schreibart überhaupt und zur Beredsamkeit insonderheit, Königsberg, Scriptor Verlag, 1755.

LONGUENESSE, B.: Kant and the Capacity to Judge, Princeton, Princeton University Press, 1998.

MEER, R.: Der transzendentale Grundsatz der Vernunft. Funktion und Struktur des Anhangs zur Transzendentalen Dialektik in der Kritik der reinen Vernunft, Berlin/New York, de Gruyter, 2019.

MÖSENBACHER, R.: 'Kants Ringen um 'einige objective Gültigkeit' der Prinzipien der reinen Vernunft”, Incipiens 5 (2016) 71-97.

MOLEDO, F.: "Über die Bedeutung der objektiven und der subjektiven Deduktion der Kategorien", Kant-Studien 106 (2015) 418-429.

PATON, H. J.: Kant's Metaphysics of Experience. A Commentary on the First Half of the Kritik der reinen Vernunft, vol. 1, London/New York, Georg Allen and Unwin, 1936.

POLLOK, K.: “An almost single Inference - Kant's Deduction of the Categories Reconsidered", Archiv für Geschichte der Philosophie 90 (2009) 323-345.

RESCHER, N.: Kant and the Reach of Reason. Studies in Kant's Theory of Rational Systematization, Cambridge, Cambridge University Press, 2000.

RIEHL, A.: Der philosophische Kritizismus. Geschichte und System, vol. 1, Leipzig, Engelmann, 1876.

RITZEL, W.: "Die Transzendentale Deduktion der Kategorien 1781 und 1787”, in HEIDEMANN, I.; RITZEL, W. (eds.): Beiträge zur Kritik der reinen Vernunft 1781-1981, Berlin/New York, de Gruyter, 1981.

STRAWSON, P. F.: The Bounds of Sense. An Essay on Kant's Critique of Pure Reason, London/New York, Methuen, 1966.

SULZER, J. G.: “Art. Eingang”, in Allgemeine Theorie der Schönen Künste, in einzeln, nach alphabetischer Ordnung der Kunstwörter auf einander folgenden Artikeln abgehandelt, part 2, Leipzig, Weidmann, Reich, 1771. 
THÖLE, B.: "Die Beweisstruktur der transzendentalen Dialektik in der zweiten Auflage der Kritik der reinen Vernunft", in FUNKE, G. (ed.): Akten des 5. Internationalen Kant-Kongresses, Vol. 1, Bonn, de Gruyter, 1981.

WEISE, C.: Politischer Redner, das ist kurtze und eigentliche Nachricht, wie ein sorgfältiger Hofmeister seine Untergebenen zu der Wohlredenheit anführen soll, Kronberg, Taunus, 1683 [Printed facsimile from an exemplar of the Herzog August Library]. 


\title{
¿Por qué son —según Kant- imposibles las hipótesis en matemática?
}

\author{
REYNA FORTES ${ }^{1}$
}

\begin{abstract}
Resumen
El tratamiento de las hipótesis en Kant es disperso. Sin embargo, hay en el Nachlass una cuestión que, si bien no tiene un lugar protagónico, sí que permanece inalterada en su pensamiento: que las hipótesis son imposibles en la matemática. Esto contrasta con el hecho de que es por medio de ellas como es posible el avance del conocimiento científico. La respuesta a esta pregunta, no dada por Kant, conecta, a mi juicio, con aspectos centrales relativos al carácter a priori del conocimiento y a su alcance sintético.
\end{abstract}

Palabras clave: hipótesis, juicios, conceptos, matemáticas

Why are-according to Kant—impossible hypotheses in mathematics?

\begin{abstract}
Kantian treatment of hypothesis is rambling. However, we can find in his Nachlass a proposal that, even though it does not have a leading place, it does remain unchanged in his thought; that is to say, that the hypothesis are impossible in mathematics. This contracts with the fact that it is precisely through these hypothesis that the scientific progress is possible. The answer to this question, one that Kant did not provide, is connected, according to my point of view, to the central aspects related to the a priori character of knowledge and its synthetic scope.
\end{abstract}

Keywords: hypothesis, judgements, concepts, mathematics

\footnotetext{
${ }^{1}$ Universidad de Navarra. Contacto: rafaelreynafortes@gmail.com. Este texto ha sido redactado durante mi estancia en la Martin-Luther Universität Halle-Wittenberg. Debo a los profesores Rainer Enskat, que tan cordialmente me acogió allí, y Alejandro Vigo, director de mi tesis, las ideas que vertebran este trabajo.
} 


\section{Introducción}

Las hipótesis, como queda de relieve en la obra de Kant, no son un elemento central en su pensamiento, ${ }^{2}$ aunque sí que lo es la ciencia. ${ }^{3}$ Esto no deja de ser sorprendente en la medida en que ellas son, precisamente, el medio por el que el conocimiento científico progresa (Logik, 9: 86). El estudio kantiano de las hipótesis en la literatura filosófica es ciertamente escaso y, cuando se lo ha llevado a cabo, se ha hecho sin prestar especial atención ni a la consistencia lógica que les conviene, ${ }^{4}$ ni tampoco a su carácter problemático. ${ }^{5}$

Por otro lado, es bien sabido que la matemática es considerada por Kant un tipo de saber apodíctico y con validez universal. ${ }^{6}$ Sin embargo, como se puede comprobar en $R 2689,{ }^{7}$ el regiomontano no acepta la existencia de hipótesis en la matemática. Así, esta disciplina contribuye, por una parte, a la ampliación del conocimiento del mundo (Prol., 4: 280; KrV BXII-XIV) y, al mismo tiempo, no necesita de hipótesis. ¿Cómo puede un conocimiento

\footnotetext{
${ }^{2}$ Para encontrar un material adecuado para este asunto es necesario estudiar las Logik Vorlesungen (Logik, 9: 84; V-Lo/Pölitz, 24: 558-559; V-Lo/Wiener, 24: 886-887; V-Lo/Blomberg, 24: 89-90; VLo/Philippi, 24: 440; V-Lo/Dohna, 24: 746), el Nachlass $(R$ 2687, $R$ 2694, $R$ 2693, $R$ 2681, $R$ 2690, $R$ $2679, R 2678$ ) y algunos lugares de las obras publicadas ( $K r V$ BXIII/XIV; A769/B797; KU 5: 466; $S F$ 7: 83; Prol., 4: 369). Para un tratamiento adecuado de los problemas editoriales que conlleva el estudio de las lecciones de lógica véase Capozzi (2002: 145-184). En el caso de las obras publicadas, el desarrollo de las hipótesis, excepto en $K r V$, permanece siempre vinculado a otros temas. De ahí surge la necesidad de dar una visión de conjunto de ellas.

${ }^{3}$ Así lo han mostrado diversos autores como Friedman (1992: 55-165; 2012: 299-327), Buchdahl (1969: 638-639), Heidegger (2009: 93-139) y Arana (1982: 151). Es cierto, empero, que existen oposiciones entre algunos de estos autores que quedan recogida por Friedman (2012: 301).

${ }^{4}$ Destaca en esta ocasión Vaihinger (1986: 634), quien intenta un abordaje de dicha cuestión desde su teoría del ficcionalismo haciendo justicia, en efecto, al carácter heurístico, pero perdiendo de vista la forma lógica que hace posible dicho carácter.

${ }^{5}$ En este aspecto merecen especial mención los trabajos de Butts (1961: 153-170; 1962: 185-203). Este autor tiende a ver en Kant a un filósofo de la ciencia quizás más que al filósofo trascendental que fue. Es muy acertado, a pesar de ello, el valor otorgado por Butts al carácter problemático del constructo hipotético que se deriva de su conexión con una experiencia posible.

${ }^{6}$ Para un tratamiento de la reflexión kantiana sobre la matemática véanse Koriako (1999), WolffMetternich (1995), Enskat (1978) y Shabel (2012). En esta obra es común la opinión de que la matemática constituye un caso especial de conocimiento acerca del mundo por medio de objetos que solo son posibles, como tales, para los hombres. Para esta tesis véase, en concreto, Enskat (1978: 127138) y Koriako (1999: 232-237).

${ }^{7}$ Kant señala en este texto que tampoco hay hipótesis en metafísica y en moral. Aquí intentaré centrar la atención en el motivo por el que ellas no tienen lugar exclusivamente en matemática. Cabe decir, empero, que se trata de un motivo análogo que contraviene el carácter problemático que se desprende de la forma lógica de las hipótesis. Estas, como se intentará hace ver, permanecen siempre en un régimen de validez problemático, mientras que en metafísica, matemática y moral, dicha problematicidad queda cancelada por la índole de su objeto.
} 
científico avanzar prescindiendo justo de aquello por lo que se caracteriza él mismo, es decir, el método hipotético?

En este trabajo, pretendo explicar, a través de una consideración de la estructura lógica de las hipótesis y de los requerimientos que plantean, el motivo por el que Kant rechaza este modo de proceder en la matemática. Esto conduce a algo que, como se verá, ha sido considerado, por diversos autores, como un aspecto fundamental del pensamiento del filósofo alemán: la relación entre juicios y conceptos. ${ }^{8}$

\section{Hipótesis y experiencia}

Para una primera aproximación a las hipótesis intentaré una determinación positiva de las mismas en tres puntos y, luego, una negativa que permita distinguirlas de otras realidades que guardan cierta similitud con ellas. Tras esto, procuraré exponer la propiedad que considero más definitoria del constructo cognitivo que Kant conoce con el término de hipótesis.

Pues bien, lo que permanece vinculado a las hipótesis en el tratamiento kantiano de las mismas se puede resumir, a mi juicio, en los siguientes puntos: i) tienen un carácter problemático; ii) heurístico; ${ }^{9}$ y iii) para ii) y i) es necesario el cumplimiento de tres requisitos, a saber, no implicar contradicción, unidad con lo que ellas explican y unidad en ellas mismas.

En lo referente al carácter problemático debe decirse que la hipótesis no es otra cosa que una opinión ${ }^{10}[$ Meinung], es decir, proposiciones que

\footnotetext{
${ }^{8}$ Para un examen de esta idea, véase Reich (1992: 42-46), Longuenesse (1998: 107-131), Wieland (2001: 364ss) y Vigo (2006; 2008).

${ }^{9}$ En lo que respecta a estas dos connotaciones, las hipótesis están en cierta proximidad conceptual con los prejuicios [Vorurteile] y los juicios preliminares [vorläufige Urteile]. La exposición de estos tipos de juicios se encuentra, en su mayor parte, en las lecciones de lógica (V-Lo/Pölitz, 24: 545; V-Lo/Dohna, 23: 737; V-Lo/Wiener, 24: 861; v. también V-Lo/Blomberg, 24: 161). Poniendo base en los textos y siguiendo a La Rocca (2001: 354) y Capozzi (2002: 629), puede afirmarse que en tales juicios están involucradas prestaciones reflexivas de modo tales que dichos juicios no pueden ser considerados conocimiento en sentido genuino, sino que, más bien, lo posibilitan. Es por esto que considero necesario distinguirlos de las hipótesis, de modo que el género de prejuicios e hipótesis son los juicios preliminares, siendo así aquellas especies que se distinguen, a mi juicio, por la forma lógica de las hipótesis.

${ }^{10}$ La cuestión de los modos del tener por verdadero [Fürwahrhalten] es tratada por Kant en $\mathrm{KrV}$ A820/B848; A832/B860, así como también en las lecciones de lógica. Esta cuestión es de gran interés, no solo por las conexiones que desde ahí se pueden establecer con la lógica epistémica sino, sobretodo, a mi juicio, porque abren la consideración de una prestación de la facultad del juicio que, de otro modo, quedaría oculta. En efecto, todo juicio es una vinculación de representaciones. Sin embargo, el valor
} 
gozan tan solo de fundamentos subjetivos. En contraposición al saber [Wissen] y a la creencia [Glauben], este modo de tener por verdadero pone algo de modo meramente posible. Vale, pues, decir que la hipótesis, en lo que a su modo de ser tenidas por verdadero se refiere, elevan las mismas pretensiones de conocimiento que una opinión. La diferencia estriba en las prestaciones cognitivas que se le atribuyen por el hecho de ser hipótesis y no una mera opinión. Son estas prestaciones de las hipótesis las que las hacen un medio indispensable [unentbehrlich] (Logik, 9: 86; V-Lo/Dohna, 24: 746) para la ciencia de la naturaleza, pues las hacen precursoras de conocimientos sin ser ellas mismas conocimiento en sentido genuino. ${ }^{11}$

En definitiva, puede decirse que toda hipótesis es opinión pero no viceversa ya que, más bien, una hipótesis es un modo de opinar por medio de la razón $(R$ 2693). Esta exigencia de la razón añadida a la mera opinión queda encarnada en los tres requisitos antedichos que, al mismo tiempo, coinciden con los requerimientos planteados tanto por la forma misma del pensar ${ }^{12}$ (de los conceptos), como por la experiencia. ${ }^{13}$ Asimismo, a estos conjuntos de restricciones se les añaden las de la razón, cuyo papel no es otro que el de orientarla ${ }^{14}$ precisamente al cumplimiento de esas mismas condiciones.

Todos estos requisitos para considerar a una opinión como una hipótesis, como se ha dicho, tienen su correlato tanto en las condiciones de la experiencia como también en el cumplimiento de las mismas que exige la

epistémico de estas está en estrecha vinculación con la facultad de la que proviene. Cabría, pues, introducir aquí la doctrina de la Reflexión Trascendental de la Anfibología de los Conceptos de Reflexión, es decir, con una prestación cognitiva que acompaña a la reflexión lógica (que tan solo exige la concordancia de las notas de un concepto) con la conexión de dichas representaciones con las facultad de la que provienen.

${ }^{11}$ Esta misma idea es expresada por Butts (1961: 156), quien la vincula estrechamente con la propiedad regulativa que tienen estas ideas. Podría decirse que la regulatividad de un conocimiento consiste precisamente en que este hace posible el conocimiento sin ser él mismo conocimiento.

${ }^{12}$ En esta línea, Capozzi (2002: 671) ha advertido la presencia de las notas que definen la forma de los conceptos en los requerimientos de las hipótesis que aparecen en el misterioso y no siempre bien reconocido Kemp Smith (2003: 200; v. $K r V \S 12$ ). Esta sugerencia explica, además, por qué, al término de dicho parágrafo, Kant hace referencia a las hipótesis mismas. Para un estudio de dicho fragmento en esta dirección, v. Vigo (2008) y Natterer (2003: 344-379).

${ }^{13}$ Butts (1961: 159) sugiere aquí la diferencia entre hipótesis y opinión señalando que, mientras la primera es un conocimiento en conexión con la experiencia, la segunda es un mero juego con pensamientos [play with thoughts].

${ }^{14}$ Destaca en esta línea el trabajo de Krausser (1987) que acentúa, quizás hasta el punto de no hacer del todo justicia a las condiciones de la experiencia, la acción que tiene la razón sobre el entendimiento. De este modo conecta el texto de Krausser con la comprensión de las hipótesis que aparece en $V$ Lo/Dohna, 24: 736, consistente en considerar la opinión como un modo de opinar a través de la razón (v.t. $R$ 2690, $R$ 2693, $R 2682$ ). 
razón. Esta determinación, sin embargo, es tan solo de carácter negativo, ya que solo permite detectar qué no es una hipótesis, pero, para atender ahora a lo que tienen de específico, hace falta aclarar que son fundamentos de explicación de fenómenos [Erklärungsgründe]. ${ }^{15}$ En efecto, a la hora de formular una hipótesis, ella misma debe poner en relación aquello que explica con su fundamento. Es necesario, pues, suponer que existe una explicación para todos los fenómenos, ${ }^{16}$ así como también que la relación entre la condición y lo condicionado nos permite, de algún modo, transitar del efecto hacia la causa. Es desde esta perspectiva desde donde, creo, pueden verse mejor por qué los requisitos de las hipótesis son tales y no otros.

Según la sugerencia recién indicada, el acceso a la causa que nos brinda la hipótesis viene ocasionado por el efecto, por lo que aquello que pueda ser causa de un efecto determinado debe cumplir, al mismo tiempo, las condiciones de la experiencia, puesto que es dentro de ella donde aparece la relación causa-efecto. De lo contrario, encontraríamos dentro del sistema kantiano una brecha para escapar más allá de los límites de la experiencia. Para ilustrar esta idea, resulta de gran interés el siguiente texto de Prolegómenos (4: 297):

\footnotetext{
${ }^{15} \mathrm{KU}$, 5: 466; Logik, 9: 94; V-Lo/Pölitz, 24: 558; V-Lo/Wiener, 24: 886; V-Lo/Philippi, 24: 225. En todos estos lugares, como se podrá observar, se hace referencia a que las hipótesis son un modo de tener por verdadero la verdad de una causa por la suficiencia de las consecuencias. Se trata, por tanto, de un uso heurístico de la forma del juicio problemático. Más adelante trataré esto; baste, sin embargo, señalar que se trata de valor heurístico y no de valor de verdad. En efecto, una hipótesis debe poder ser verificada, pero nunca en todas sus consecuencias. Este régimen problemático permanente de la hipótesis se debe a la presencia del concepto empírico en el seno del juicio en que consiste la hipótesis. Por otro lado, debe decirse algo importante y es que, del mismo modo que se excede aquí el planteamiento de la filosofía de la ciencia, también se rebasa el de las hipótesis causales. Son pocos, efectivamente, los lugares en los que Kant desarrolla esto, pero un lugar que podría verse al respecto es Prol., 4: 299. Aquí Kant usa el famoso ejemplo del juicio ‘el aire es elástico' y puede verse así, a mi juicio, que al aire se le atribuye la elasticidad en la medida en que esta propiedad explica los fenómenos de expansión que tienen lugar al variar la presión a la que el aire queda sometido. Un estudio de este ejemplo se puede encontrar en Wolff (2012: 132-135). Más adelante volveré a hacer alusión a este trabajo; baste decir que el análisis de Wolff no resulta del todo acertado porque no explica cómo se aplica la categoría de sustancia en este caso, pues del hecho de que el aire cambie su forma se podría inferir tanto que este es elástico como que hay una presión que lo altera. Este ejemplo también es estudiado por Longuenesse (1998: 170-175), donde sí que queda mejor explicado cómo entra el concepto de aire bajo el de sustancia siendo, primero, subsumido bajo el de causa.

${ }^{16}$ Resulta de gran relevancia a este respecto el hecho de que Kant, en $V$-Lo/Dohna, 24: 746, se refiera a las hipótesis con el término 'presuposición real o efectiva' [wirckliche Voraussetzung]. No deja de ser esto una metáfora para traer dos nociones: la del estatuto problemático permanente y la de su valor cognoscitivo.
} 
Pues, ya que podemos tener a priori, y antes de todos los objetos dados, un conocimiento de aquellas condiciones sólo bajo las cuales es posible una experiencia respecto a ellos, pero nunca podemos saber a priori a qué leyes puedan estar sometidos ellos en sí mismos, sin referencia a una experiencia posible, nunca podremos estudiar a priori la naturaleza de las cosas de otro modo sino investigando las condiciones y las leyes universales (aunque subjetivas), sólo bajo las cuales es posible tal conocimiento como experiencia (según la mera forma).

Según este texto, poseemos un conocimiento a priori de las condiciones de la experiencia aunque no sepamos a qué leyes obedecen los objetos fuera de ella. ${ }^{17}$ De aquí infiere Kant que nunca seremos capaces de estudiar la naturaleza sino anticipando formalmente las condiciones subjetivas y universales de la experiencia. Esta afirmación podría resultar paradójica si se pasara por alto el hecho de que las condiciones antedichas son universales precisamente porque son subjetivas, y que, por eso mismo, son también a priori. En efecto, el despliegue de las condiciones de la experiencia posible coincidirá con las leyes de la naturaleza solo si se atiende a que naturaleza y experiencia son, para Kant, las dos caras de la misma moneda, de modo que lo que conocemos por experiencia es la naturaleza y, al mismo tiempo y en esa misma medida, las condiciones de la primera son las leyes de la segunda.

Este breve comentario permite la consideración del tipo de anticipación formal del que nos proveen las hipótesis. No podemos, en efecto, saber cuál es la causa de un fenómeno dado como podría ser el caso del calentamiento de una piedra. ${ }^{18}$ Ahora bien, en ningún momento se duda de

\footnotetext{
${ }^{17}$ Son bastantes los conceptos que están en juego aquí. Baste señalar a este respecto que las leyes universales de la naturaleza son el plexo legal al que los fenómenos se adecúan, es decir, la natura formaliter spectata ( $\mathrm{KrV}$ B165). Por otro lado, siendo coherentes con ello, las leyes de los objetos se corresponden con la natura materialiter spectata $(\mathrm{KrV} \mathrm{B} 163)$. Podría decirse que la primera trata de las leyes que el investigador de la naturaleza anticipa formalmente y la segunda de las que este mismo investigador encuentra en virtud de dicha anticipación. En esta línea, el trabajo de Mudroch (1987: 4345 ) resulta de gran relevancia, pues conecta esta misma temática con el Opus Postumum y MA. No se trata, pues, cuando Kant habla aquí de objetos en sí, de noúmenos, pues estos ni siquiera son objeto, sino tan solo una reificación del concepto de objeto trascendental. En contraste con esto, en el comienzo del $§ 14$ de Prolegómenos, Kant habla de "la naturaleza como la existencia de las cosas en cuanto determinadas por leyes universales" (4: 294) y, por tanto, en la medida en que se trata de la existencia, esta es relativa al sujeto. Dichas leyes, pues, deben ser las Analogías de la Experiencia (v., para un estudio de estos parágrafos, Pollock 2012: 103-127).

${ }^{18}$ Los ejemplos que Kant da de una hipótesis son muy diversos y la mayoría de ellos permiten concluir bastante poco. Empleo aquí el ejemplo de un juicio de experiencia ya que, además de ser más común y más conocido, puedo así dar a entender que el planteamiento kantiano excede el de la filosofía de la
} 
que haya una causa de dicho efecto. ${ }^{19}$ Este no dudar de la presencia de una razón explicativa (o, si se quiere, de la actividad de una causa) es el tipo de requerimiento al que me he referido más arriba. Sin embargo, esta anticipación formal solo provee utensilios para indagar las causas de un determinado efecto sin los cuales sería imposible cualquier búsqueda según leyes de experiencia y, por tanto, tampoco de naturaleza.

Es precisamente por el cumplimiento de tales condiciones por el que la opinión se reviste de un carácter heurístico que la hace no dejar de ser problemática, pero sí ser apta para su transformación en asertórica. En efecto, si ha de cumplir las exigencias que plantea la posibilidad de ser dada a la experiencia, también debe satisfacer los requerimientos que plantean tanto la sensibilidad como el entendimiento. Así, pues, el carácter heurístico que conviene a la hipótesis le es conferido por su adecuación a la experiencia posible. No hay que perder de vista el hecho de que en ningún caso la hipótesis deja der ser opinión. Más bien, de lo que se trata es de que deja de ser opinión, pues tan solo es una opinión que adquiere la forma de hipótesis.

Ahora bien, como se ha dicho, el tipo de conocimiento que obtienen las ciencias es necesario, pero ¿de dónde surge dicha necesidad, si la hipótesis es afirmada de modo problemático? Pues bien, para responder a esta pregunta es indispensable recurrir a una distinción que no está directamente establecida en Kant, pero que considero análoga a otra que sí lo está, a saber, la que permite distinguir una proposición y un juicio. ${ }^{20}$ Según él, una proposición es siempre asertórica. En cambio, en un juicio la relación pensada es siempre

ciencia evitando así anacronismos. En cualquier caso, cabe hace notar que el más notorio de estos ejemplos es el del sistema copernicano donde Kant se centra en la evolución a partir del sistema de Tycho de Brahe (v. Logik, 9: 85; V-Lo/Blomberg, 24: 221-222; V-Lo/Pölitz, 24: 559; V-Lo/Philippi, 24: 441; V-Lo/Wiener, 24: 887-888). Como he dicho al principio, de la misma manera en que Kant muy raramente centra su atención en las hipótesis, también puede entenderse, a la inversa, que pueda haber lugares en los que el análisis de Kant pueda aportar alguna luz al estudio de las hipótesis.

${ }^{19}$ El que dicha anticipación formal nos provea de una presuposición que, además, siempre es respondida por la naturaleza, es lo que a juicio de Vigo (2017: 136-140) desata la reflexión teleológica que aparece en la segunda parte de $K U$. Está muy íntimamente relacionado con esta conexión el trabajo de Fricke (1990: 48), que sintetiza en una frase esta idea: "un objeto debe ser considerado como un fin, cuando el concepto de ese objeto puede contarse como una causa de las causas de este objeto".

${ }^{20}$ Según esto, y como el propio Kant señala (Logik, 9: 108-109), "proposición problemática” y "juicio asertórico" constituyen una suerte de contradictio in adiecto. Esto parece chocar con la doctrina mantenida en obras como $\mathrm{KrV}$. Sin embargo, si se entiende a la proposición como un tipo específico de juicio asertórico, parece diluirse la problemática. Puede rastrearse también esta diferencia implícitamente en la MSI 2: 393, al apuntar Kant a un uso lógico y un uso real de los juicios. Este le otorga un alcance objetivo al conocimiento; en cambio, el otro solo examina su armonía conceptual. 
problemática. En coherencia con esto, creo que puede establecerse en el campo de las hipótesis la distinción entre formarlas y formularlas. ${ }^{21}$ Lo primero consistiría en la construcción del contenido proposicional que, en un segundo momento, sería tomado como asertórico, como dado. Así, el primero de estos momentos tendría que cumplir con los requerimientos de no contradicción y unidad mientras que el segundo solo tiene que afirmar o formular la hipótesis. ${ }^{22}$

\section{Juicio problemático e hipótesis}

Es necesario introducir ahora una consideración acerca de la forma y la materia de los juicios problemáticos (que enuncian una sola posibilidad), ya que solo así resulta posible llevar a cabo la tarea de determinar la estructura lógica que le corresponde a una hipótesis. En efecto, en Kant, la materia de los juicios problemáticos son dos juicios y la forma es la de la consecuencia (Logik, 9: 105-106; V-Lo/Pölitz, 24: 580; V-Lo/Wiener, 24: 932-934; KrV A73/B98-99). De este modo, lo afirmado en el juicio problemático no es ni el antecedente ni el consecuente, sino más bien el tipo de relación establecida entre ambos. Es necesario señalar aquí que el hecho de que una hipótesis tenga dos juicios no significa ni puede significar que sea un silogismo. ${ }^{23} \mathrm{En}$ este último caso, se trata de un tipo de constructo lógico totalmente distinto del judicativo, pues en él se lleva a cabo una producción de conocimiento por

\footnotetext{
${ }^{21}$ Capozzi (2002: 678-679) resalta la importancia de este momento y apunta a que las hipótesis son tales mientras haya alguien que las defiende. Al dejar de ser defendidas estas en la comunidad científica, se convierten en mera opinión ( $V$-Lo/Philippi, 24: 442). Se puede añadir, según esto, un nuevo requisito que no afecta al contenido de la hipótesis pero que define su particular modo de ser tenida por verdadera. El ejemplo de Kant alude a la muerte de Monatessa, último defensor del sistema ptolemaico. Como consecuencia de su fallecimiento, dicho sistema fue considerado como mera opinión.

${ }^{22}$ Longuenesse (2005: 137-138), en su explicación de la deconstrucción kantiana del principio de razón suficiente (Logik, 9: 51) comenta y señala que en ese texto Kant trata de los requerimientos que todo juicio necesita para ser una proposición. Resulta de gran interés el hecho de que, para tal conversión, es necesaria la conformidad tanto con el principio de contradicción como también con el de razón suficiente y, para este último caso, es indispensable i) que se siga de la verdad de las consecuencias la del fundamento y ii) que todas ellas sean, además, verdaderas. Esto, creo, no nos debe llevar, como así ocurre en el caso de Longuenesse, a considerar la verdad de las hipótesis como la verdad de un juicio. En efecto, para no alterar el carácter problemático de las hipótesis es necesario no perder de vista que son solo opiniones. Esto se fundamenta, a mi juicio, en que los conceptos que están a la base de las hipótesis son siempre de carácter empírico y, por eso mismo, no es viable una presentación completa de los mismos.

${ }^{23}$ En este punto, me opongo al tratamiento de esta cuestión que es desarrollado por Longuenesse (2005: 166). Considero que sería más correcto decir que la formulación de la hipótesis, y no su formación, sí que se desarrolla en la forma de un silogismo en la medida en que la menor del juicio problemático es convertida en asertórica y actúa como término medio de un silogismo donde la mayor es el juicio problemático. Esto mismo intentaré aclararlo un poco más adelante.
} 
medio de cualesquiera procesos. Ahora bien, un juicio problemático no es, en efecto, ningún silogismo, aunque aquel se resuelva por medio de uno.

Con ocasión de esta última idea, a mi parecer, puede llegarse a entender fácilmente en qué consiste una hipótesis. Para ello, considero necesario traer a la luz en qué consiste para Kant un silogismo problemático (Logik, 9: 129):

Un silogismo hipotético es uno tal que tiene, como mayor, una proposición hipotética - consiste, por tanto, en dos proposiciones: 1) una precedente (antecedens) y otra consecuente (consequens) y se sigue, o bien de modo ponente, o bien de modo tollente.

Observación 1. Los silogismos hipotéticos no tienen, pues, un termino medio, sino que se muestra en ellos mismos la consecuencia de una proposición a partir de otra. Se expresa en la mayor del mismo [silogismo], en efecto, la consecuencia de dos proposiciones entre sí, de la cual la primera es premisa y la segunda una conclusión. La menor es la transformación de la condición problemática en una proposición categórica.

Pues bien, según este texto, puede verse claramente que la mayor de un silogismo hipotético es un juicio problemático ${ }^{24}$ que, a su vez, se compone de dos juicios. La menor de dicho silogismo es la misma proposición que en el juicio problemático se sitúa de lado del consecuente pero, esta vez, transformada en asertórica. No hay, pues, en efecto, término medio, pues el silogismo se resuelve revistiendo de carácter asertórico al consecuente.

Para mostrar, entonces, lo específico de las hipótesis no hay que perder de vista lo que se refiere al modo de ser tomadas ellas por verdaderas. Estas, en efecto, tienen la forma de un juicio problemático, pero no son meramente un juicio tal, pues ellas presuponen que a un cierto fenómeno le precede una causa a la cual se accede solo a través de dicho fenómeno. Por otro lado, como se ha intentado hacer ver, es menester diferenciar

\footnotetext{
${ }^{24}$ En este punto podría advertirse una contradicción en el propio texto al hacer uso del término 'proposición hipotética' [hypothetischer Satz]. Vásquez-Lobeiras (2000: 167) lo traduce directamente por 'hipótesis'. Sin embargo, a mi juicio, la hipótesis tiene dos momentos, como he dicho antes. En este caso se trataría del contenido proposicional de la hipótesis. Pero no hay que olvidar que existe otro, al que Kant alude un poco más adelante, que consiste en la formulación de la hipótesis. Por otro lado, si advertimos que una proposición hipotética es un tipo de juicio hipotético que se usa como mayor en una hipótesis, parece que la problemática terminológica, de algún modo, se diluye. En cualquier caso, no hay que dejar de barajar la posibilidad de que estas dificultades se deban a la edición de Jäsche.
} 
cuidadosamente los momentos de formulación y de formación de una hipótesis ya que resulta que si no se les presta la adecuada atención, parecería haber una injerencia del primero sobre el segundo. En efecto, podría parecer que debe haber una transformación del consecuente en asertórico dentro de una hipótesis pero, de ser esto así, estaríamos hablando de un silogismo hipotético y no de una hipótesis, que no es otra cosa que un tipo de juicio problemático.

El único modo, en mi opinión, en que podemos salvar esta dificultad y conseguir así dar con la forma lógica adecuada es introduciendo una conjunción lógica en el momento de formación de la hipótesis junto a la consecuencia que implica el juicio problemático, dentro de otro. Quedaría, pues, la siguiente estructura lógica:

$$
((P \rightarrow Q) \wedge P) \rightarrow Q
$$

Según esto, lo dado es $Q$, el fenómeno que es objeto de explicación, y la causa del mismo es $P$. La estructura de una hipótesis es, de acuerdo con la forma de un juicio hipotético, una consecuencia y, además, una tal que impone una serie de requisitos a $P$. Al término del cumplimiento de los mismos, $P$ pasa a ser apta para ocupar el lugar del antecedente. Sin embargo, esto no garantiza el carácter asertórico. Esta carencia sería, según la formulación propuesta, subsanada por la introducción de la conjunción.

\section{Conceptos empíricos y juicios sintéticos}

Expuesta ya la forma lógica de las hipótesis, resta ahora considerar el papel que juegan en ellas los conceptos. Pues bien, en un juicio categórico del tipo $S$ es $P, S$ y $P$ son conceptos que juegan dos funciones distintas. La del concepto sujeto es referencial-identificatoria, mientras que la de $P$ es predicativa o determinativa (Vigo 2004: 758-759). Ambas tareas son complementarias, pues $P$ identifica (en el caso de un juicio afirmativo) una nota determinada en $S$ que, a su vez, se refiere a un objeto. Los distintos 
juicios, como señala Reich (1992: 47-58), suponen distintos usos de los conceptos. $^{25}$

Pues bien, si una hipótesis es un determinado tipo de juicio hipotético, entonces, los conceptos tendrán que jugar aquí el papel de fundamento $\mathrm{y}$ consecuencia ( $K r V$ A73/B98-99). Ahora bien, como acertadamente señala Longuenesse (1998: 354-356), bajo esta forma no tienen solo que expresarse causas sino también consecuencias lógicas que podrían ser igualmente establecidas en la forma de un juicio categórico. Así, por ejemplo, al afirmar 'si un cuerpo es extenso, entonces, es divisible' no se ha ido más allá del concepto de cuerpo. Esto mismo podría ser expresado diciendo simplemente 'todo cuerpo extenso es divisible'. ${ }^{26}$

Muy distinto es el caso antes mencionado del juicio 'si el sol calienta la piedra, esta se calienta', en el que, usando esta misma forma de los juicios hipotéticos, se hace referencia a una causa. Ambos juicios tienen la forma $S$ $\rightarrow P$; sin embargo, ninguno de ellos, aun siendo muy distintos entre sí, es propiamente una hipótesis. ${ }^{27}$ Es necesario, siguiendo la sugerencia de Longuenesse, distinguir entre fundamento lógico y causa. Lo primero es una condición necesaria; lo segundo, en cambio, es una condición suficiente. En efecto, la causa no es otra cosa que una condición suficiente ${ }^{28}$ mientras que

\footnotetext{
${ }^{25}$ Esta tesis de Reich supone ya un clásico dentro de la literatura kantiana. Según esta afirmación, las categorías de relación no son otra cosa que modos de vinculación posible entre conceptos. Esto, a su vez, viene determinado por la índole del concepto mismo que puede o no hace viable un determinado uso. Para un examen crítico de la postura de Reich, véase Enskat (2015: 216-224). En esta línea, Longuenesse (1998: 42) apunta a que los modos de producir conceptos están ya guiados por el objetivo de formar parte de juicios en virtud de los conceptos de la Anfibología.

${ }^{26}$ Es interesante atender aquí al hecho de que en el juicio problemático, incluso tras su transformación en asertórico, el concepto que en el primero hacía las veces de consecuente tiene la misma función referencial-identificatoria que en el juicio categórico. El quid de la cuestión reside, a mi juicio, en el empleo del concepto que se lleva a cabo en tal juicio y no solamente en la forma del juicio. Digo 'solamente' porque no solo no hay que perder de vista que la forma de un juicio hace viable un uso u otro, sino que también es necesario considerar que dichas formas, como en este caso, permiten usos análogos que pueden conducir a error.

${ }^{27}$ No digo aquí que la forma $S \rightarrow P$ es la de una hipótesis, sino más bien que ellas tienen la forma de un juicio problemático que queda alterado por la presencia de conceptos empíricos dentro de ella. Lo que sí tiene dicha forma, en efecto, es el contenido del paréntesis al que se le añade la conjunción. Por ejemplo, el juicio 'si el sol ilumina la piedra, esta se calienta' no es una hipótesis. En cambio, si se dice 'si el sol ilumina la piedra, esta se calienta $y$ si, de hecho, el sol la ilumina, entonces, se calienta', en tal caso, digo, sí que estamos ante la presencia de una hipótesis.

${ }^{28}$ von Wright (1993: 114-118) ha contribuido a distinguir el tipo de concepto de condición suficiente en que consisten las causas de condición en general. Según su interpretación de la relación causal, la estructura del juicio hipotético, cuando ella pone en relación dos eventos dados, entonces, y solo entonces, hace uso de la categoría de causalidad. En sede kantiana podría decirse que solo cuando la
} 
el fundamento lógico puede ser expresado como una condición necesaria. En efecto, para que un cuerpo sea cuerpo es necesario que sea extenso. No ocurre lo mismo, como se verá ahora, cuando se emplea una estructura causal.

Antes se ha usado el ejemplo de juicio de experiencia que Kant propone en Prolegómenos para explicar algo similar. Volviendo ahora sobre este modelo, puede verse que aquello que es puesto como causa del calentamiento de la piedra, a saber, el sol, no solo es causa de este fenómeno, sino que también lo es de la cera cuando se derrite, del endurecimiento de la arcilla ( $K r V$ A765/B793) y de la evaporación del agua. Un mismo objeto puede causar distintos efectos siendo una sola su manera de causar en todos estos casos. No es, pues, posible, al menos en el ámbito empírico, aislar las causas de las sustancias sobre las que actúan produciendo así sus efectos. En estrecha relación con esto debe volver a decirse también que el concepto de condición que actúa como antecedente en un juicio que busca reconocer una relación causal es empírico y debe satisfacer no solo los requerimientos de una condición en general, sino también y en particular los que se le exigen para ser considerado una condición suficiente. ${ }^{29}$

Enskat (2015: 46), apoyándose tanto en la interpretación de Heidegger como en su propia comprensión de los Prolegómenos, ha ofrecido una visión de este fenómeno más que coherente. En lo que a la propuesta de Heidegger se refiere, se trata de una contribución que hace este autor en su trabajo $L a$ pregunta por la cosa, según la cual en los tipos de proposiciones 'porque/por eso' [weil/deshalb] existe una conexión que presenta requerimientos que solo pueden ser satisfechos por referencia a la intuición. ${ }^{30}$ En efecto, para poder afirmar que el sol calienta la piedra es necesario cierta vecindad temporal

estructura del juicio hipotético expresa una relación entre fenómenos apoyada sobre juicios de percepción, solo en tal caso, se puede hablar de un empleo de la categoría de causalidad.

${ }^{29}$ Un ejemplo claro de esta necesaria 'suficiencia' de la condición se puede encontrar en Prol., 4: 312, donde Kant señala: "Pero es posible que se encuentre en la percepción, una regla de la relación que diga que a un cierto fenómeno le sigue constantemente otro [...] si un cuerpo es iluminado por el sol durante un tiempo suficiente (lange gnug)". Estas condiciones marcan la índole necesariamente sensible del tipo de representación provista por tales conceptos como puede ser la coexistencia $\mathrm{Kr} V$ A202-203/B247-248 o la proximidad espacio-temporales $\mathrm{KrV}$ B162-163.

${ }^{30}$ No es inusual este tipo de referencias a la intuición no solo en el período crítico (Prol., 4: 285-287; $K r V$ A260-269/B316-325) sino también y de modo aún más decisivo en la etapa pre-crítica $(N G, 2$ : 171-177; GUGR, 2: 382-383; MSI, 2: 398). Para un estudio de todas ellas en referencia al espacio, véase Placencia (2007). El propio Enskat (2015:103-104) reconoce, además, en el texto de GUGR, uno de los hallazgos más relevantes de la etapa pre-crítica. Esta comprensión de dicha evolución del pensamiento kantiano parece coincidir con la de Wolfgang Carl (1989), quien ostenta, a mi juicio, la visión más coherente de esta temática. Para un examen de dicho periodo resultan de interés los trabajos de Vleeschauwer (1962), Fang (1967), Villacañas (1980) y Falgueras (1999). 
entre ambas representaciones que Heidegger (2009: 177) reconoce con el término ser-conjuntamente [Zusammensein]. En tales juicios se expresa, pues, conocimiento objetivo en la medida en que se pasa del juicio 'siempre que/entonces' al de 'porque/por eso', y también, por ende, cuando se supera la dispersión temporal de la conciencia empírica a través de la acción del juzgar.

Enskat (2015: 152-182) interpreta así no solo DTB, sino también los Prolegómenos y DTA. Dicha dispersión temporal de la conciencia empírica, término presente en $D T B$, coincidiría con el uso del término 'experiencias' (en plural) en DTA (A110) y con el de los juicios de percepción en Prolegómenos. Pues bien, este último tipo de juicios son los que, en la interpretación de Enskat (2015: 36-37), constituyen el suelo de la experiencia [Bathos der Erfahrung] en el que radica el carácter fructífero de las condiciones de posibilidad de la misma. Según esta comprensión del texto kantiano, dichos juicios, y no las meras percepciones, ${ }^{31}$ son el núcleo germinal desde el cual tanto la matemática pura como la ciencia de la naturaleza se elevan. La metáfora kantiana del suelo de la experiencia hace referencia al carácter germinal que poseen los juicios de percepción así como, también, a las condiciones bajo las cuales pueden ser obtenidos ciertos frutos a partir de dichos juicios. Pues bien, dichos frutos no son otros que los juicios

\footnotetext{
${ }^{31}$ Enskat (2015: 38) cifra la diferencia entre la forma de un juicio de percepción 'yo percibo que $p$ ' y la mera percepción en que el primero implica una cierta elaboración por parte del sujeto. Esta labor consistiría en atribuirse a sí mismo dicho sujeto las percepciones que él tiene en cada caso. La conciencia, por tanto, que acompaña a tales juicios es dispersa en la medida en que le corresponde unívocamente a la percepción que mienta. Más aún, el autor (Enskat 2015: 41) distingue, además, entre juicios de percepción y juicios de percepción maduros [ausgereiftete], juicios estos que son objeto de un desarrollo más profundo por parte del sujeto. Un ejemplo de los mismos se puede encontrar en 'Yo, que percibo una torre, percibo en ella el color rojo' (Logik, 9: 113). El paso de los meros juicios de percepción a juicios maduros de percepción se desarrolla a través de la función unitiva que juega el $Y o$ pienso en la $D T B$; sin embargo, sigue tratándose, no puede olvidarse, de juicios que elevan una pretensión de validez subjetiva y que solo predican sobre lo que en cada caso se percibe. Aquí juegan un papel importante los conceptos de la Anfibología en la medida en que permiten vincular representaciones entre sí formando conceptos. En definitiva, la conciencia empírica, podría decirse, madura, es, en continuidad con la interpretación de Enskat, el correlato subjetivo del concepto empírico que es elaborado, según su forma, por medio de los tres procesos descritos (Comparación [Vergleichung], Reflexión [Reflexio] y Abstracción [Abstrahieren]) en las lecciones de lógica (Logik, 9: 94; V-Lo/Pölitz, 24: 566-567; V-Lo/Busolt, 24: 654; V-Lo/Wiener, 24: 907-908). La presencia de la reflexión y de los conceptos anfibológicos que la acompañan constituye, cada vez de modo más notable, un elemento central en la investigación de Kant, véase Longuenesse (1998: 131-167), Reuter (1989) y Vigo (2008).
} 
de experiencia y dichas condiciones no son otras que las de la posibilidad del carácter fructífero [Fruchtbarkeit] de la experiencia.

Según dicha teoría, es necesario afirmar que la imposición de las categorías sobre los juicios de percepción constituye el paso del mero juicio de percepción al de experiencia. Si se mantienen ambos separados, entonces, no se obtiene en absoluto conocimiento en sentido propio. ${ }^{32}$ En cambio, cuando se unifican tienen lugar juicios objetiva y universalmente válidos.

Pues bien, retomando lo dicho sobre las hipótesis y teniendo en cuenta lo exigido para la formación de juicios de experiencia, hay que admitir que, para pasar de un juicio 'siempre que/entonces' a uno 'porque/por eso', es indispensable estar en posesión de juicios de percepción de tal modo que ellos hagan viable la constitución de la experiencia. En efecto, para hacer juicios sintéticos es necesario ampliar mi concepto, es decir, predicar de él notas de modo que se amplíe su conocimiento. Ahora bien, cuando el concepto es empírico y busco realizar un juicio sintético tomándolo como base, entonces, requiero de un recurso a la experiencia que me provea de una confirmación que, además, debe ser constante (Prol., 4: 327). Se trata, pues, aquí, de juicios sintéticos a posteriori.

No ocurre así, por otro lado, con los juicios analíticos, donde no es necesaria confirmación. Sin embargo, estos últimos no amplían en nada mi conocimiento, en la medida en que estoy ya en posesión de todas las nota que he predicado de él. Aquí, empero, no se aprende nada sobre los objetos, sino sobre el concepto del que predico en cada caso.

\section{Las características de los juicios matemáticos}

Ahora bien, lo que acontece en los juicios sintéticos a priori y, en concreto, en la matemática pura resulta del todo chocante pues, en ella se alcanza un conocimiento i) objetiva y universalmente válido, ii) por construcción conceptos y iii) con recurso a la experiencia pero, iv) sin necesidad de

\footnotetext{
${ }^{32}$ Esto, como ha advertido el propio Enskat (2015: 152-153), conecta tanto con el así llamado problema de Gettier (1963), como también con el de Platón al final del Teeteto. Se trata, en efecto, del problema de la justificación del saber. Según Kant, dicha solución vincularía tanto un elemento de carácter perceptivo (los juicios de percepción) y otro lógico (como es la forma de las categorías). La Deducción Trascendental de las Categorías, en sintonía con esto, habría tenido como objetivo encontrar la legitimación de la justificación de la que gozan ya los juicios de experiencia.
} 
confirmación constante. Por así decir, los juicios matemáticos poseen las virtudes de todos los demás juicios. Estas características, como intentaré mostrar ahora, pueden reducirse unas a otras de modo que se pueda entender mejor el motivo por el cual los juicios matemáticos ${ }^{33}$ reportan conocimiento sintético por mera construcción de conceptos.

Para explicar como reducir, en primer lugar, iii) a i), resulta de interés traer a colación aquí un texto de Beweisgrund en el que Kant nos ofrece una idea decisiva para entender cuál es el recurso a la experiencia que se hace en matemática y que exime a esta ciencia de la confirmación constante que, en cambio, sí requeriría de un conocimiento válido sobre objetos:

No hay que decir: En la naturaleza existen hexágonos regulares; sino más bien: En la naturaleza hay ciertos objetos como las celdillas de las abejas y el cristal de la roca, a los que corresponden los atributos que percibimos en un hexágono $(B D G, 2$ : 73).

Según este breve fragmento, puede distinguirse el hexágono regular de los objetos que presentan una figura hexagonal de tal modo que, a través de la determinación de las propiedades de un hexágono, puedo conocer también las propias del objeto en cuanto que posee tal tipo de forma. Esta posibilidad, sin embargo, parece contravenir el pensamiento de Kant en la medida en que constituiría un caso en el que cabría un discurso acerca de un objeto prescindiendo de que este hubiese sido dado. Tal aparente contradicción es registrada por el regiomontano tanto en su tratamiento de la matemática (KrV A721/B749; Prol., 24: 292-293), como en el apartado dedicado a la distinción entre fenómenos y noúmenos ( $K r V$ A240/B299).

Con ocasión de esta advertencia, Kant busca señalar que, para considerar un determinado conocimiento como una experiencia, es necesario que el objeto sea dado en la intuición y esto lo hace de tal modo que le permite sostener, al mismo tiempo, el carácter apodíctico de la matemática. Por seguir con el texto de Beweisgrund, debe señalarse que no es posible hablar de

\footnotetext{
${ }^{33}$ La matemática se divide en distintas disciplinas para Kant, a saber: geometría (por referencia al espacio), aritmética (por referencia al tiempo) y mecánica pura (que relaciona espacio y tiempo). En todos los casos juega un papel esencial la participación del concepto de quantum (Friedman 1992: 55164). Según esto, la matemática se funda en la determinación de una unidad que pueda darse con ocasión de la intuición pura o también en general, como ocurre en álgebra.
} 
hexágonos existentes, sino de objetos que, en la medida en que son dados en la intuición, responden a las cualidades que estudio en un hexágono. Por tanto, también podría decirse que, mientras se considere el hexágono como un objeto solo para el entendimiento en relación a una intuición meramente posible (o, si se quiere pura), ${ }^{34} \mathrm{y}$ solo mientras tanto, cabe afirmar que el conocimiento recabado de tal modo es universalmente válido $\mathrm{y}$, por ende, apodíctico. En resumen, debería afirmarse que todo conocimiento apodíctico es universalmente válido, pero no al revés. El conocimiento que describe a un objeto con forma hexagonal es siempre a posteriori por cuanto que requiere de la intuición del objeto. ${ }^{35} \mathrm{Sin}$ embargo, el conocimiento posible acerca de un objeto hexagonal, en la precisa medida en que le corresponde la forma del hexágono, es a priori. ${ }^{36}$

En lo referente al contenido de los juicios que se refieren a objetos hexagonales y al de los que presentan el hexágono no hay ninguna

\footnotetext{
${ }^{34}$ Heidegger (2009: 189) define la innovación kantiana en lo relativo a la explicitación de la esencia del juzgar por medio de la inclusión de la forma pura de la sensibilidad junto a las formas lógicas. Esto está, además, en estrecha relación con la consideración que este mismo autor (2009: 93-139) realiza sobre el papel que juega la matemática en el pensamiento kantiano. Para un estudio de las relaciones entre Kant y Heidegger, v. Volpi (2006). Por otro lado, en lo referente a la determinación de la esencia del juicio, considero de gran interés los estudios de Wolff (1995: 7) y Enskat (2015: 103-151). El primero de ellos intenta descubrir en la definición kantiana del juicio, presente en $M A$, 4: 475 nota, el núcleo central de dicha operación. Por su parte, Enskat (2015: 109) se muestra crítico con esta visión y apunta a que no es posible una completa [vollständige] definición del juzgar sino tan solo una definición determinada a un contexto operativo. Por ello, Enskat $(2015: 111,119,127)$ trabaja con definiciones de trabajo [Arbeitsdefinitionen] que están presentes a lo largo de toda su obra. Para un estudio de los distintos problemas de la definición en Kant, v. Beck (1956) y Straulino (2016: 126-129).

${ }^{35}$ Aportone (2009: 159ss) ha expresado una diferencia entre las nociones de categoría y concepto puro del entendimiento que, creo, es análoga a la distinción entre el objeto con propiedades geométricas y el objeto geométrico. En efecto, la categoría consiste en la forma del pensar de un objeto en contraposición al concepto puro del entendimiento que es un constructo cognitivo. En otras palabras, se trata de que la categoría es el concepto puro del entendimiento puro en cuanto permite un conocimiento de objetos $\mathrm{y}$, por otro lado, de la misma categoría pero solo pensada como un objeto intelectual.

${ }^{36} \mathrm{Y}$ es por esto por lo que Wollf-Metternich (1995: 98) señala que, en sentido estricto, el objeto de la matemática no es sino la forma misma de los objetos. Esta tesis es sostenida por el propio Kant en $\mathrm{Kr} V$ (A240/B299) cuando afirma que "las matemáticas cumplen este requisito [de ser convertido en sensible] construyendo la figura, la cual constituye para los sentidos un fenómeno presente (a pesar de ser producido a priori)". La vinculación entre necesidad y conocimiento a priori es de vital importancia para la comprensión del pensamiento de Kant. En relación al conocimiento matemático, Flamarique (1991: 57) ha observado que los "juicios aritméticos y geométricos, que se dan siempre mediante una intuición, son a priori y necesarios, por lo que la intuición, que es medio del juicio, debe ser pura, noempírica". Según esto, la necesidad no convendría tanto al pensamiento si no a los juicios que se realizan bajo ciertas condiciones. Esto, creo, nos permite considerar una idea que se desarrolló un poco más arriba con ocasión del concepto de condición suficiente, y es que los juicios de percepción son, ellos mismos, las condiciones (o, quizás mejor, las circunstancias) para realizar juicios de experiencia (Prol., 4: 299).
} 
diferencia. ${ }^{37}$ En cambio, en lo relativo a la posición de dicho conocimiento sí que se presenta una característica distintiva, a saber: los primeros poseen un carácter asertórico; los segundos, en cambio, apodíctico. En efecto, en el caso de los juicios sobre objetos hexagonales se desarrolla una descripción objetiva, pero cuando se trata de hexágonos tan solo hay referencia a una recreación mental abstracta que nunca puede alcanzar la riqueza de su imagen.

Por tanto, podría decirse que los puntos antedichos i) y iii) pueden identificarse en la medida en que los juicios matemáticos describen objetos de una experiencia posible $\mathrm{y}$, más aún, tienen carácter apodíctico precisamente por la misma razón por la que son considerados a priori, a saber: en la medida en que dicha experiencia es solo posible. Efectivamente, el discurso que trata de la experiencia posible es él mismo apodíctico en la medida en que se refiere a las condiciones necesarias de la experiencia. ${ }^{38}$

Como se ha procurado señalar, al paso del mero juicio de percepción al de experiencia le precede otro que va desde la mera percepción al juicio de percepción. En otras palabras, al paso de la conciencia empírica a la pura le antecede la transición desde la sensación (inconsciente) a la conciencia de la misma: la constitución del concepto empírico. En efecto, para poder realizar un juicio de experiencia es necesario tener a disposición juicios de percepción

\footnotetext{
${ }^{37}$ Esto explica la referencia a la matemática que Kant lleva a cabo en $K U, 5: 363$. En dicho pasaje se afirma que "ellos [los antiguos] estudiaban, por ejemplo, las propiedades de la parábola sin conocer la ley de la gravedad terrestre, que les habría suministrado la aplicación de tales propiedades a la trayectoria de los cuerpos pesados". Lo que el regiomontano observa en este hecho, a mi juicio, es que el estudio de las parábolas, solo cuando se las comprende como meros objetos del pensamiento, sirve como método para la ciencia newtoniana que estudia la caída de los graves que, a su vez, dibujan el mismo movimiento parabólico. La admiración [Vewunderung] consistiría en volver sobre esta concordancia que produce en nosotros un cierto asombro [Bewunderung] que, al mismo tiempo, no es otra cosa que un cierto choque $[$ Anto $\beta]$ sobre el espíritu [Gemüt $](K U, 5: 365)$.

${ }^{38}$ En relación a la necesidad que gobierna en el discurso sobre las condiciones de la experiencia posible, Baum (2015: 155) ha señalado que si "se presupone la posibilidad de la experiencia, entonces valen también sus condiciones objetivas y necesarias. Ellas tienen validez objetiva para todo objeto posible de experiencia aunque no se experimente por una deducción subjetiva cómo estos conceptos hacen posible la experiencia y por qué son las categorías las que juegan este papel”. En efecto, la necesidad de las categorías no depende de una deducción ya que son precisamente ellas necesarias para la experiencia posible para el hombre. Para esta misma cuestión es de gran valor la aportación de Enskat (2015: 42-22) para distinguir la justificación que adquirimos por la experiencia y los fundamentos de la misma que nos provee una Deducción Trascendental. Para lo primero puede decirse que el hombre justifica su conocimiento desde la percepción. Lo segundo, en cambio, se relaciona con el quid iuris de la deducción que reconoce dicha pretensión. Los fundamentos de justificación, vale decir, la legitiman. La necesidad, por tanto, del discurso sobre las condiciones de la experiencia, es una necesidad que, de algún modo, es interna al propio discurso y es correlativa a la justificación.
} 
en la medida en que ellos son una conciencia de las propias sensaciones [Empfindungen]. ${ }^{39}$ Este progreso hacia la conciencia empírica puede materializarse, como he intentado hacer ver, con el paso de la sensación $X$ al del juicio 'yo percibo que $X$ ', al que le sigue, a través de la vinculación con otros juicios de percepción (como: 'yo percibo que $Y$ ' y, en un nivel superior de reflexión, 'yo, que percibo $X$, percibo en él $Y$ '), un juicio de experiencia ' $Y$ es $X$ '. Esto mismo es relativamente más sencillo de captar cuando se trata de juicios que se basan en una intuición empírica. Sin embargo, este mismo proceso subyace también a la formación de conceptos sensibles puros, como el de los objetos geométricos.

Efectivamente, cuando se tiene presente a la intuición pura que, en sí misma, no deja de ser una abstracción, en la medida en que solo es la forma de la intuición en general, solo entonces, puede darse la posibilidad de asistir a la formación de conceptos puros sensibles. Esto es brevemente explicitado por Kant en el siguiente texto del Esquematismo: ${ }^{40}$

De hecho, nuestros conceptos puros sensibles no reposan sobre imágenes, sino sobre esquemas. Ninguna imagen de un triángulo se adecuaría jamás al concepto de triángulo en general [...] El esquema de triángulo no puede existir más que en el pensamiento, y significa una regla de síntesis de la imaginación respecto de figuras planas en el espacio ( $\mathrm{KrV}$ A141/B180).

Según este texto, lo que acontece en la formación de un concepto sensible puro no es lo mismo que ocurre en la de un concepto meramente

\footnotetext{
${ }^{39}$ En las lecciones de lógica, Kant desarrolla una gradación del conocimiento según su valor objetivo (Capozzi 2002: 145-184). A través de una reconstrucción de los distintos grados puede observarse la tesis de que la percepción [Wahrnehmung] es una cierta toma de conciencia de la sensación [Empfindungen] (V-Lo/Dohna, 24: 730; $R$ 426, R 2394; V-Lo/Pölitz, 24: 539; Logik, 9: 64-65). Dentro de la $K r V$ cabe acudir a A166/B207: "Percepción quiere decir conciencia empírica, es decir, una conciencia en la cual tenemos, a la vez, sensación”. Sobre la percepción se ejecuta un nuevo procedimiento al que Kant da el nombre de conocer [kennen], cuyo objetivo no es otro que la comparación de las percepciones según identidad y diferencia (Logik, 9: 64-65; V-Lo/Dohna, 24: 730731; V-Lo/Philippi, 24: 418; V-Lo/Blomberg, 24: 135-136; R 2394).

${ }^{40}$ No quisiera demorarme demasiado en la intricada historia del esquematismo. Sin embargo, considero conveniente señalar que la teoría de la que me he servido en este trabajo es la desarrollada por Koriako (1999: 222-237) y Wolff-Metternich (1995: 43-62), en lo referente a lo específicamente matemático, y la de Rosales (2009: 241-310) y Caimi (2015), en lo que al papel de las categorías y de los conceptos empíricos se refiere. Además, para una reconstrucción de los vaivenes en la interpretación del esquematismo, v. Koriako (1999: 222-223, nota 11).
} 
empírico como, por ejemplo, el de perro. ${ }^{41}$ En este último caso, se constituye un concepto a partir de las imágenes sensibles. En cambio, en la consolidación del concepto de un objeto geométrico todo se desarrolla (o puede desarrollarse) a priori, de tal modo que no pueda darse una definición de triángulo independientemente de la descripción de la regla que se necesita para dibujar un triángulo. ${ }^{42}$ Precisamente por eso, porque el esquema de triángulo es el modo en que lo trazamos, este solo tiene lugar en la conciencia. Ahora bien, el concepto de triángulo no es ninguna de sus imágenes, sino el resultado de la aplicación del primero a través del esquema y sobre la intuición pura. Este procedimiento es reconocido en general por Kant con el nombre de esquematismo y en el caso de los conceptos puros sensibles se denomina construcción.

El contraste con el empleo de esquemas en el caso de los conceptos empíricos es de gran utilidad para entender por qué Kant vincula a la definición de los objetos matemáticos una cierta arbitrariedad (UD, 2: 276; $K r V$ A717/B745) ${ }^{43}$ que, al mismo tiempo, sustenta la posibilidad de una definición completa de los mismos. Y es que para definir o trazar un objeto geométrico, el recurso a la intuición pura no puede venir determinado por ella puesto que ella es, en cuanto pura, carente de determinaciones $(\mathrm{KrV}$

${ }^{41}$ Koriako (1999: 229-230) apunta aquí a que la definición de 'perro' debe ser siempre una tal que sea válida para la referencia a este o aquel perro por medio de las notas específicas de este mamífero. En cambio, la definición del concepto de triángulo no es sino una instrucción para la construcción de uno. Toda definición que busque presentar un concepto empírico no será, pues, otra cosa que una definición nominal (KrV A728/B756; Logik, 9: 143).

${ }^{42}$ Koriako (1999: 255), con otras palabras, hace referencia a esto mismo señalando que "los conceptos matemáticos no son, por tanto, conceptos a los que debería serles proporcionada una referencia a la sensibilidad, sino que ellos no son otra cosa que una regla de la síntesis de la imaginación, en vista de las formas puras en el espacio". La referencia a la intuición pura juega un papel constitutivo en el trazo de un objeto geométrico que, siguiendo la tesis antes referida de Wolff-Metternich, no es otra cosa que la forma del objeto. Reconstruyendo el contenido de Prolegomena, Shabel (2012: 77-78) ha llegado a una conclusión que entronca con trabajos antes mencionados en los siguientes términos: "Según Kant, el pensar matemático se refiere, por consiguiente, a la misma estructura o la forma de la sensibilidad de modo que aquello que nosotros conocemos particularmente cuando comprendemos a priori una verdad matemática sobre un objeto matemático, reúne la forma o estructura de los objetos sensibles, a saber, espacio y tiempo".

${ }^{43}$ En este último texto, Kant afirma que la matemática elige cierta denominación de sus construcciones. Precisamente en este punto se juega la diferencia fundamental entre las categorías y los conceptos sensibles puros. Si nos remitimos aquí a $K r V$ (B201), donde Kant establece la diferencia entre los dos tipos de vinculación [conjunctio] de los que es capaz el entendimiento (y, por tanto, de toda vinculación posible para el espíritu humano como se podría seguir de $K r V$ B130). Según dicha doctrina, la composición [compositio], al contrario que la conexión [nexus], relaciona sus partes sin una implicación necesaria. Kant señala aquí que esto es lo que "ocurre con la síntesis de lo homogéneo que es susceptible de ser tratado matemáticamente". Para una discusión del distinto papel que juegan las categorías matemáticas y dinámicas en el modelo de constitución kantiano de la experiencia véase Vigo (2015). 
A35/B39). ${ }^{44}$ En efecto, toda posible fijación de cualquier punto en el espacio conlleva directamente una situación del mismo en una superficie que en sí misma no posee nada objetivo. Más aún, todo lo que en ella podría encontrarse no remite sino a la situación del sujeto con respecto al espacio en general. Así surgen, por ejemplo, los conceptos de izquierda/derecha o arriba/abajo que no se basan, como el propio Kant indica, en otra cosa que en un sentimiento [Gefühl] (WDO, 8: 134-135). Pues bien, es precisamente por la determinación del espacio que habilita este sentimiento por lo que, a mi juicio, Kant atribuye arbitrariedad a los conceptos geométricos, es decir, porque no hay en la intuición pura otra determinación distinta de la que emana del propio sujeto.

Pues bien, en la medida en que todo el contenido del concepto puro sensible puede identificarse con el esquema y este solo tiene lugar en el pensamiento, aunque ( $o$, quizás, más bien, precisamente porque) se realiza sobre la intuición pura, puede decirse que el procedimiento denominado 'construcción de conceptos' exime de la confirmación constante y puede así reducirse el punto ii) al iv). En efecto, en la medida en que el contenido del concepto de triángulo (por tanto, de este o de aquel) es una determinada realización de lo que ya estaba en la mente, a saber, el esquema (que, a su vez, no es otra cosa que una determinación de la intuición pura por parte del entendimiento y es, pues, completamente $a$ priori), la confirmación está dada ya en la intuición pura. ${ }^{45}$

En conexión con lo dicho hasta ahora puede entenderse el siguiente texto de la $K r V$ :

\footnotetext{
${ }^{44}$ Lo mismo ocurre también con el tiempo ( $K r V$ A31/B47). Es de particular interés, en este último texto, el que Kant fundamente la apodicticidad de los principios y axiomas precisamente en esta propiedad de la intuición pura consistente en no ser un conocimiento discursivo. En lo referente a la definición del quantum: "En la medida en que esta conciencia de la diversidad homogénea dada en la intuición en general es la que hace posible la representación de un objeto, constituye el concepto de quantum" ( $\mathrm{Kr} V$ B203). En este último caso, el quantum no es otra cosa que la determinación que lleva a cabo la conciencia de un concepto dentro de la intuición pura. Para un estudio de esta misma cuestión, v. Longuenesse (1998: 143-192).

${ }^{45}$ Este estar ya antes en la mente como condición subjetiva de la experiencia es precisamente lo que Kant tematiza en Prol., 4: 281, cuando formula la pregunta: “¿cómo es posible intuir a priori algo?". La respuesta de Kant consistirá en afirmar que "sólo de una única manera es posible [...] que mi intuición preceda a la realidad del objeto y tenga lugar como conocimiento a priori; a saber, si mi intuición no contiene nada más que la forma de la sensibilidad, que precede, en mi sujeto, a todas las impresiones reales mediante las cuales soy afectado por los objetos" (Prol., 4: 282).
} 
La explicación real será, pues, aquella que no sólo explica un concepto, sino que explica, a la vez, la realidad objetiva del mismo. Las explicaciones matemáticas, donde se presenta en la intuición el objeto correspondiente al concepto, son de esta última clase $\left(\mathrm{KrV}\right.$ A242) ${ }^{46}$

Efectivamente, si retomamos lo antedicho acerca de las explicaciones, puede entenderse por qué las reales son precisamente las matemáticas y no otras. Y esto ocurre precisamente porque la constitución del objeto geométrico (o, si se quiere, de la figura de un objeto en general) coincide perfectamente con la construcción del concepto mismo. En otras palabras, la construcción del concepto puro sensible, inmediatamente, representa su realidad objetiva y ello, también a la inversa, justo porque construir un concepto en la intuición es ya presentarlo. ${ }^{47}$ En esta línea, y en conexión con lo dicho un poco más arriba, podría, pues, afirmarse que el objeto geométrico 'triángulo' es el concepto de triángulo, mientras que el objeto triangular es al que, fuera de la mente, le corresponden las propiedades del triángulo.

Desde aquí, habiendo reducido i) a iii) y iv) a ii), puede verse ahora de qué modo sería posible que los juicios matemáticos sean, al mismo tiempo, apodícticos y sintéticos, a saber, en la precisa medida en que la construcción de los conceptos matemáticos es una acción del pensamiento que se apoya sobre un elemento invariable como es el de la forma pura de la intuición. ${ }^{48}$ En efecto, porque los conceptos matemáticos tienen sus raíces en la forma pura de la sensibilidad y son generados también por esa injerencia del entendimiento reconocida con el nombre de esquematismo, por todo ello,

\footnotetext{
${ }^{46}$ Para un estudio de esta misma cuestión, véase Flamarique (1991: 57-64) y Shabel (2012: 71-74).

${ }^{47}$ Es precisamente por esto también que Kant afirma (KrV A792/B820) que "esta ciencia [la matemática] es el ámbito propio de las demostraciones apagógicas" ya que estas "sólo son permisibles en las ciencias en las que es imposible sustituir lo objetivo de nuestras representaciones por lo subjetivo de las mismas" (KrV A791/B819). En efecto, según esto, lo subjetivo, que no es otra cosa que la determinación del sentido interno en que consiste la formación de una figura geométrica, es, al mismo tiempo, lo objetivo, es decir, la figura del objeto mismo.

${ }^{48}$ En relación a esto mismo Kant indica también que "una prueba (Beweis) apodíctica sólo puede llamarse demostración (Demostration) en la medida en que es intuitiva [...] En consecuencia, sólo las matemáticas poseen demostraciones, debido a que su conocimiento no deriva de conceptos, sino de la construcción de los mismos, es decir, de la intuición que puede darse a priori en correspondencia con ellos" (KrV A734/B762). Es conveniente tomar en consideración ahora la aclaración filológica ofrecida por Kant en $K r V$ A730/B758 que afirma que "la lengua alemana no posee para expresar los términos "exposición" (Expositio), “declaración" (Deklaration) y "definición" (Definition) más que la palabra Erklärung". Según esto, debe decirse que el tipo de prueba en que consiste la demostración matemática no es si no una explicación intuitiva y también, por eso mismo, apodíctica.
} 
puede observarse cómo es que los juicios matemáticos gozan de la apodicticidad de los analíticos y amplían, al mismo tiempo, el conocimiento acerca de objetos. Por tanto, hay que retrotraer la división de los juicios sintéticos y analíticos no a la condición de su carácter apodíctico sino, más bien, al concepto que se sitúa a la base del juicio en cada caso. ${ }^{49}$

\section{Conclusión: la ausencia de hipótesis en matemáticas}

De acuerdo con lo visto hasta ahora, es posible descubrir el sentido de la tesis kantiana acerca de la imposibilidad de la presencia de hipótesis en matemáticas. En efecto, toda hipótesis es, como se dijo al principio, un determinado tipo de explicación por referencia a una condición. La estructura explicativa coincide, por tanto, con la de los juicios problemáticos en la medida en que los juicios empleados en la explicación reposan sobre conceptos que son, en cada caso, tomados como condición y condicionado.

De este modo, dar con una explicación de un fenómeno $Y$ por referencia a uno anterior $X$ permite decir 'si $X$, entonces $Y$ '. Ahora bien, como también se pudo observar, la índole de los conceptos que desarrollan el oficio de condición y condicionado en un juicio con las antedichas características juega un papel decisivo en el tipo de explicación que se pretenda dar. Así, todo juicio problemático que tenga a su base dos juicios que se sustenten sobre conceptos meramente lógicos jamás podrá ser considerado hipótesis, $\mathrm{y}$ una prueba de ello se podría encontrar en el hecho de que, en tal caso, el juicio problemático podría ser traducido en la forma de uno categórico. Puede rastrearse esto con facilidad en el juicio 'si $X$ es un cuerpo, entonces, $X$ es extenso' y su correspondiente transformación en juicio categórico 'todo cuerpo es extenso'.

Cuando los conceptos presentes son de tipo empírico, entonces, ocurre algo bien distinto, y es que no puede transformarse el juicio problemático en categórico. Por ejemplo, el juicio 'el sol calienta la piedra' no puede ser transformado en un juicio categórico. Esto acontece precisamente porque el

\footnotetext{
49 "Efectivamente, a un concepto dado hay que agregarle en el pensamiento un cierto predicado, y tal necesidad es inherente a los conceptos. Pero la cuestión no reside en qué es lo se debe agregar al concepto dado, sino en qué sea lo que de hecho se piensa en él, aunque sólo sea de modo oscuro. Entonces queda claro que, si bien el predicado se halla necesariamente ligado a dicho concepto, no lo está en cuanto pensado en éste último, sino gracias a una intuición que ha de añadirse al concepto" ( $\mathrm{Kr} V$ B17).
} 
carácter empírico de los conceptos hace imposible una definición completa de los mismos y, por ende, también que, relacionando estos dos conceptos, no pueda formularse un juicio analítico. Dicha transformación, en efecto, solo puede ocurrir cuando se trata de un juicio de este último tipo, es decir, allí donde no voy más allá de ese concepto.

Se llegó así, antes, a extrapolar la forma que poseen las hipótesis y que consistía en un determinado tipo de juicio problemático que, con la injerencia de la conjunción lógica, permitía reconocer la índole problemática que poseen los conceptos empíricos que entran en juego en una hipótesis.

Ahora bien, este reconocimiento del régimen problemático de las hipótesis tiene sentido solo dentro de la comprensión kantiana de la ciencia de la naturaleza y su progreso efectivo. Sin embargo, en lo que se refiere a las matemáticas, precisamente en la medida en que toda construcción (o definición) del concepto matemático implica de inmediato su presentación (o constitución), solo en tal medida, digo, es imposible una sola hipótesis en matemáticas. Esto no quita el hecho de que en la matemática sí son posibles juicios hipotéticos. Lo que no es posible en ella es, sin embargo, la hipótesis o, mejor dicho, la prestación particular que ofrecen los juicios hipotéticos cuando se busca dar una explicación de fenómenos a través de ellos.

\section{Referencias}

Fuentes primarias

KANT, I.: Gesammelte Schriften, Berlin/Leipzig, Preussische Akademie der Wissenschaften, Deutsche Akademie der Wissenschaften zu Berlin, Akademie der Wissenschaften zu Göttingen, Georg Reimer, Walter de Gruyter \& Co, 1900.

: Crítica de la Razón Pura, $3^{\mathrm{a}}$ ed., trad. RIBAS, P., Taurus, Madrid, 2010.

: Prolegómenos a toda metafisica futura que haya de poder presentarse como ciencia, trad. CAIMI, M., Madrid, Istmo, 1999, : Lógica: un manual de lecciones, trad. VÁSQUEZ LOBEIRAS, M. J., Madrid, Akal, 2000.

: Critica del Discernimiento, trad. RODRÍGUEZ ARAMAYO, R.; MAS, S., Madrid, Machado libros, 2003. 
Fuentes secundarias

APORTONE, A.: Gestalten der transzendentalen Einheit, Berlín/Nueva York, Walter de Gruyter, 2009.

ARANA, J.: Ciencia y metafisica en el Kant precrítico (1746-1764), Sevilla, Universidad de Sevilla Secretariado de Publicaciones, 1982.

BAUM, M.: "Kants "Möglichkeit der Erfahrung"”, en ENSKAT, R. (ed.): Kants Theorie der Erfharung, Berlín/Nueva York, Walter de Gruyter, 2015.

BECK, L. W.: "Kant's Theory of Definition", The Philosophical Review 65 (1956) 179-191.

BUCHDAHL, G.: Metaphysics and the Philosophy of Science, Cambridge, MA, MIT Press, 1969.

BUTTS, R. E.: "Kant on Hypotheses in the "Doctrin of method" and the Logik", Archiv für Geschichte der Philosphie 44 (1962) 185-203.

: "Hypothesis and Explanation in Kant's Philosophy of Science", Archiv für Geschichte der Philosphie 43 (1961) 153-170.

CAIMI, M.: "Der Schematismus der reinen Verstandesbegriffe", en ENSKAT, R. (ed.): Kants Theorie der Erfharung, Berlín/Nueva York, Walter de Gruyter, 2015.

CAPOZZI, M.: Kant e la logica, Nápoles, Bibliopolis, 2002.

CARL, W.: Der Schweigende Kant. Die Entwürfe zu einer Deduktion der Kategorien vor 1781, Göttingen, Vandehoeck \& Ruprecht, 1989.

ENSKAT, R.: Urteil und Erfahrung, Gotinga, Vandenhoech \& Ruprecht, 2015.

FALGUERAS, I.: Perplejidad y filosofia trascendental en Kant, Cuadernos de Anuario filosófico, Pamplona, Servicio de Publicaciones de la Universidad de Navarra, 1999.

FANG, J.: Das Antinomienproblem im Entstehungsgang der Traszendentalphilosophie, Münster, Verlag Regensberg, 1967.

FRIEDMAN, M.: Kant and the Exact Sciences, Cambridge, MA, Harvard University Press, 1992.

: "The Prolegomena and Natural Science", en LEYRE, H.; SCHLIEMANN, O. (eds.): Kants Prolegomena. Ein kooperativer Kommentar, Frankfurt am Main, Klostermann, 2012.

FRICKE, C.: "Explaining the Inexplicable. The Hypotheses of the Faculty of Reflective Judgment in Kant's Third Critique", Nô̂s 1 (1990) 45-62. 
FLAMARIQUE, L.: Necesidad y conocimiento: fundamentos de la teoría crítica de Kant, Pamplona, EUNSA, 1991.

GETTIER, E.: “Is Justified True Belief Knowledge?”, Analysis 6 (1963) 121123.

HEIDEGGER, M.: Die Frage nach dem Ding, Tübingen, Max Niemeyer Verlag, 1987.

: La pregunta por la cosa, trad. GÓMES GARCIA DEL VALLE, J. M., Girona, Palamedes Editoral, 2009.

KEMP SMITH, N.: A comentary to Kant's Critique of Pure Reason, Nueva York, Palgrave Macmillan, 2003.

KORIAKO, D.: Kants Philosophie der Mathematik. GrundlagenVoraussetzungen-Probleme, Hamburg, Felix Meiner Verlag, 1999.

KRAUSSER, P.: "Über den hypothetischen Vernunftgebrauch in der KrV", Archiv für Geschichte der Philosophie 69 (1987) 164-195.

LA ROCCA, C.: "Vorläufige Urteile und Urteilskraft. Zur heuristischen Logik des Erkenntnisprozesses", en GERHARDT, V.; HORSTMANN, R-H.; SCHUMACHER, R. (eds.), Kant und die Berliner Aufklärung, vol. II, sektionen I-V, Berlin/New York, Walter de Gruyter, 2001.

LONGUENESSE, B.: Kant et le pouvoir de juger, París, Presses universitarie de France, 1993.

: Kant and the capacity to judge, trad. WOLFE, C. T., Nueva Jersey Princeton University Press, 1998.

: Kant on the Human Standpoint, Nueva York, Cambridge University Press, 2005.

MUDROCH, V.: Kants Theorie der physikalischen Gesetze, Berlín/Nueva York, Walter de Gruyter, 1987.

NATTERER, P.: Systematischer Kommentar zur "Kritik der reinen Vernunft”, Berlín/Nueva York, Walter de Gruyter, 2003.

PLACENCIA, L.: La ontología del espacio en Kant. Un estudio genéticosistemático sobre los fundamentos metodológicos y metafísicos de la teoría del espacio como intuición pura en la "Estética Trascendental”, Pamplona, Cuadernos de Anuario filosófico, Serie universitaria, $\mathrm{n}^{\circ}$ 192, Servicio de Publicaciones de la Universidad de Navarra, 2007.

REICH, K.: Die Vollständigkeit der kantische Urteilstafel, Hamburg, Meiner, 1986. 
: The Completeness of Kant's Table of Judgement, trad. BECK, L. W., Stanford, Stanford University Press, 1992.

REUTER, P.: Kants Theorie der Reflexionsbegriffe. Eine Untersuchung zum Amphiboliekapitel der Kritik der reinen Vernunft, Würzburg, Königshausen \& Neumann, 1989.

ROSALES, A.: Ser y Subjetividad. Sobre el origen subjetivo de las categorías, Buenos Aires, Biblos, 2009.

SHABEL, L.: "Zu Kants Frage "Wie ist reine Mathematik möglich?"”, en LEYRE, H.; SCHLIEMANN, O. (eds.): Kants Prolegomena. Ein kooperativer Kommentar. Frankfurt am Main, Klostermann, 2012.

STRAULINO, S.: "La noción de verdad trascendental", Revista de Estudios Kantianos 2 (2016) 126-145.

VAIHINGER, H., Die Philosophie des Als ob. System der theoretischen, praktischen und religiösen Fiktionen der Menschheit aufgrund eines idealistischen Positivismus, Aalen, Scientia Verlag, 1986.

VIGO, A.: "Contingencia y finalidad. Kant y la perspectiva reflexiva sobre la naturaleza", Open Insight 13 (2017) 123-159.

: "Kategoriale Synthesis und Einheit des Bewusstseins. Zu Kants Lehre vom Verhältnis zwischen Wahrnehmung und Erfahrung”, en ENSKAT, R. (ed.): Kants Theorie der Erfharung, Berlín/Nueva York, Walter de Gruyter, 2015.

: "Conceptos trascendentales, reflexión y juicio. Sobre el $\S 12$ de la Kritik der reinen Vernunft", Diánoia 61 (2008) 73-110.

: "Reflexión y juicio", Diánoia 57 (2006) 27-64.

: "Determinación y reflexión”, Anuario Filosófico 37 (2004) 73-110.

VILLACAÑAS, J. L.: La formación de la Crítica de la razón pura, Valencia, Universidad de Valencia, 1980.

VLEESCHAUWER, H. J. d.: L'Evolution de la pensée kantienne, Alcan, Librairie Félix Alcan, 1939.

: La evolución del pensamiento kantiano: historia de una doctrina, trad. GUERRA, R., México, Universidad Nacional Autónoma de México, 1962.

VOLPI, F.: “'Comincio ad amare realmente Kant'. Heidegger scopre Kant”, Mazzarella (2006) 211-229.

WIELAND, W.: Urteil und Gefühl. Kants Theorie der Urteilskraft, Göttingen, Vandenhoeck und Ruprecht, 2001. 
WRIGHT, G. H. v.: "On the logic and epistemology of the Causal Relation", en SOSA, E. (ed.): Causation and Conditional, $2^{\mathrm{a}}$ ed., Londres/Nueva York, Oxford University Press, 1993.

WOLFF, Michael: Die Vollständigkeit der kantischen Urteilstafel. Mit einem Essay über Freges Begriffschrift, Frankfurt am Main, Philosophische Abhandlungen $\mathrm{n}^{\mathrm{o}}$ 63, 1995.

: "Die Analyse der Erfahrung ins Kants Prolegomena", en LEYRE, H.; SCHLIEMANN, O. (eds.): Kants Prolegomena. Ein kooperativer Kommentar, Frankfurt am Main, Klostermann, 2012.

WOLFF-METTERNICH, B.-S. v.: Die Überwindung des mathematischen Erkenntnisideals. Kants Grenzbestimmung von Mathematik und Philosophie, Berlín/Nueva York, Walter de Gruyter, 1995. 


\title{
El reino de los fines y la comunidad ética. Acerca de la dimensión intersubjetiva de la ética kantiana
}

\author{
ILEANA P. BEADE ${ }^{1}$
}

\begin{abstract}
Resumen
En este trabajo se consideran dos objeciones recurrentes formuladas a la doctrina ética kantiana: aquella que cuestiona su presunto carácter individualista y aquella que señala su pretendido formalismo. A partir de un análisis de las nociones de reino de los fines y de comunidad ética, se intentará mostrar que la ética kantiana, lejos de limitarse a la mera determinación de principios formales, introduce un contenido fundamental que opera como condición restrictiva de toda acción humana en general, esto es, el valor absoluto e incondicionado del ser humano como fin en sí.
\end{abstract}

Palabras clave: ética, reino de los fines, religión, comunidad ética, historia

\section{The Kingdom of Ends and the Ethical Community. On the Intersubjective Dimension of Kant's Ethics}

\begin{abstract}
In this paper I consider two recurrent objections against Kant's Ethics: one related to its alleged individualistic character, and other referred to its presumed formalism. The analysis of the notions of kingdom of ends and ethical community allows to conclude that Kant's ethical doctrine, far from restricting itself to the determination of formal principles, introduces a fundamental content that sets a restrictive condition to every human action, that is to say, the absolute and unconditioned value of the human being, regarded as an end in itself.
\end{abstract}

Keywords: ethics, kingdom of ends, religion, ethical community, history

${ }^{1}$ CONICET. Contacto: ileanabeade@yahoo.com.ar. 


\section{Introducción}

Entre las múltiples y variadas objeciones que han sido formuladas a la filosofía práctica de Kant, una de las críticas frecuentes señala que su doctrina ética desatiende importantes aspectos psicológicos, afectivos y sociales implicados en la moralidad, limitándose principalmente a una cuestión formal, a saber, la de la relación entre la máxima subjetiva que determina la voluntad y el mandato objetivo de la ley moral. A esta objeción tradicional se suma la acusación de un presunto rigorismo moral, además de otras observaciones críticas referidas, por ejemplo, a la articulación entre las diversas formulaciones del imperativo categórico o a la concepción de la libertad moral como mera obediencia a la ley, entre otras. En cuanto a la filosofía político-jurídica kantiana, esta ha sido considerada por diversos intérpretes como una teoría de sesgo conservador, en cuyo marco se exhorta a la obediencia incondicionada al poder instituido, se rechaza toda posibilidad de resistencia legítima y se restringe el derecho de ciudadanía. Otros aspectos de la filosofía práctica kantiana han sido objeto de críticas recurrentes: la posición asumida por el filósofo respecto de la pena de muerte, su concepción del matrimonio como un contrato en virtud del cual se adquiere la posesión recíproca de los órganos sexuales de los contratantes, sus observaciones eurocéntricas en el tratamiento del concepto de raza o sus comentarios descalificantes respecto del género femenino son, en efecto, aspectos que suelen despertar recelos - en ciertos casos justificados - y operan a menudo como obstáculos para una valoración general del pensamiento kantiano.

Entre los aspectos más atractivos de la filosofía práctica de Kant cabría mencionar su concepción de la ilustración y del progreso del género humano, su reivindicación del uso autónomo de la razón y, desde luego, sus reflexiones en torno al republicanismo, el derecho cosmopolita y la paz perpetua. Estos aspectos - recuperados por importantes figuras de la filosofía contemporánea en razón de su relevancia actual - resultan, en ocasiones, opacados por ciertas interpretaciones que se concentran en los aspectos antes mencionados, desatendiendo, generalmente, el vínculo inescindible entre la ética, la teoría jurídica, la filosofía política, la antropología y la filosofía de la historia en el marco de la filosofía kantiana.

En este trabajo propongo considerar dos de las objeciones a las que he aludido: en primer lugar, aquella que cuestiona el presunto carácter individualista de la ética kantiana; en segundo lugar, aquella que impugna su 
pretendido formalismo. Atendiendo a este objetivo examinaré, en primer lugar, la noción de reino de los fines, tal como aparece desarrollada en la Fundamentación de la metafísica de las costumbres y, en segundo lugar, la idea de comunidad ética, esbozada en La religión dentro de los límites de la mera razón. A través del análisis de ambas nociones y de su posible relación o articulación intentaré señalar que la ética kantiana, lejos de limitarse a la mera determinación de principios formales, introduce un contenido fundamental que opera como condición restrictiva de toda acción humana en general, esto es, el valor absoluto de la persona humana, expresado en la concepción del ser humano como fin en sí mismo. Por otra parte, la noción de un reino de los fines, que Kant deriva a partir de esa concepción del ser humano (GMS, AA 4: 433ss), ${ }^{2}$ aporta elementos relevantes al momento de identificar la dimensión intersubjetiva de la moralidad; dimensión sobre la que el filósofo repara, no solo en la Fundamentación, sino asimismo en $\mathrm{La}$ religión. En efecto, en este texto señala Kant que los conceptos morales de bien y mal pueden pensarse como esencialmente vinculados a la trama de relaciones intersubjetivas: así como el mal radical, inherente a la naturaleza humana, se manifiesta y despliega en el orden social, así también el bien es consumable a través de la institución de una comunicad ética, regida por leyes de la virtud ( $R G V$, AA 6: 96ss). ${ }^{3}$

Esta comunidad ética, a la que Kant distingue de la comunidad política, es caracterizada, en el texto de 1793, como una comunidad eclesiástica ( $R G V$, AA 6: 100-101), y ello puede dar lugar a algunos interrogantes referidos al modo en que el autor entiende la relación entre ética y religión. Cabría preguntar, en primer lugar, en qué medida la moral individual se resuelve en una moral comunitaria, es decir, en qué sentido aquella se orienta indefectiblemente a esta última. Sabemos que, en el marco de la ética kantiana, el bien moral debe conservar en todo momento su dimensión individual: la relación de la máxima subjetiva con la ley moral objetiva es aquello que determina, en todo caso, el valor moral de una acción. El reconocimiento de una dimensión comunitaria o intersubjetiva de la ética

\footnotetext{
${ }^{2}$ La paginación citada corresponde a la edición académica de las obras kantianas: Kants gesammelte Schriften (vol. I-IX) (1902ss). A esta edición aludimos, de aquí en adelante, bajo la abreviatura AA, seguida del número de tomo, indicado en numeración arábiga. Citamos la versión española de Fundamentación para una metafisica de las costumbres [Grundlegung zur Metaphysik der Sitten (2005).

${ }^{3}$ Citamos la versión española de La religión dentro de los limites de la mera razón [Die Religion innerhalb der Grenzen der bloßen Vernunft (1995).
} 
kantiana no podría desatender esta dimensión esencialmente individual de la moralidad. Es, pues, relevante la pregunta acerca de cómo entender el tránsito de lo individual a lo intersubjetivo en el ámbito moral y hasta qué punto puede ser pensado este tránsito como un devenir necesario de la ética hacia la religión. En segundo lugar, y con vistas a la caracterización kantiana de la comunidad ética como comunidad eclesiástica, cabría preguntar por qué motivos Kant, promotor de una moral autónoma de creencia religiosa, caracteriza a la comunidad ética como una iglesia.

Años antes de la publicación de La religión, en la segunda Crítica, los postulados de la razón práctica y el desarrollo de la doctrina del bien supremo anunciaban el vínculo indisoluble entre moral y religión. Pero quizás a partir de la caracterización de la comunidad ética como iglesia puede constatarse el sentido religioso que Kant atribuye al bien moral, al menos en lo que atañe a su dimensión comunitaria o social. Como ha señalado Allen Wood, esta cuestión no solo atañe a la interpretación de la filosofía moral kantiana, sino que es relevante para la comprensión de su filosofía práctica en general (su filosofía de la historia, su antropología, su doctrina jurídico-política). El intérprete identifica correctamente el motivo principal por el cual la filosofía kantiana de la religión ha sido usualmente objetada: pese a haber declarado el carácter independientemente de la moral respecto de la religión, Kant sostiene que la razón práctica conduce necesariamente a la fe, i.e., a la creencia en un Dios existente, concebido como soberano moral del mundo; y en La religión caracteriza a la comunidad ética como una iglesia. ${ }^{4}$ Estas tesis suelen despertar cierta perplejidad entre los intérpretes y han impulsado el desarrollo de diversas estrategias orientadas a dilucidar la relación entre moral y religión en el marco de la filosofía kantiana.

\footnotetext{
${ }^{4}$ Como señala Wood, la filosofía kantiana de la religión ha sido uno de los aspectos más objetados por los comentaristas: "Kant's philosophical thought about religious faith has frequently been treated as a weak point in his philosophy. Even Kant's most ardent admirers have often felt it necessary to reject and to apologize for his "moral arguments" in favor of belief in God and immortality, to admit that these arguments are beneath the high standards of the critical philosophy, and even to claim that they are incompatible with the fundamental principles of Kant's philosophy itself. The present study was undertaken in the conviction that this common estimate of Kant's doctrine of moral faith is altogether wrong. I have attempted to show not only that Kant's doctrine of moral faith is consistent with his best critical thinking, but also that a full understanding of this doctrine is necessary for any genuine appreciation of the outlook of the critical philosophy as a whole" (1970: vii). Wood se propone mostrar que la doctrina de la fe moral resulta compatible con principios fundamentales de la filosofía crítica: "Kant's doctrine of moral faith may serve us well as a guide or model in any attempt to deal rationally with questions of religion, and to apply to them that universal communicability among men which Kant considered the essence of reason and rationality" (1970: viii). A esta cuestión haremos mayor referencia en las páginas siguientes.
} 
Se trata, desde luego, de una cuestión compleja: examinar el lugar doctrinal que ocupa la religión en la filosofía crítica exigiría un análisis pormenorizado de diversos problemas específicos; por tal motivo, me concentraré aquí en algunos aspectos puntuales, a saber, cómo ha de entenderse la dimensión comunitaria propia del bien moral; en qué sentido esta dimensión comunitaria exhibe un carácter religioso y, finalmente, cómo entender la relación entre la figura moral del reino de los fines y la noción de comunidad ética. El análisis de estos tópicos permitirá dilucidar, finalmente, si es posible pensar la comunidad ética como un correlato empírico (fenoménico, histórico) del reino de los fines, caracterizado por Kant como un mundo inteligible. ¿Es la comunidad ética algo efectivamente realizable en la historia, o se trata, antes bien, de una idea de la razón práctica, esto es, de un principio regulativo que orienta las transformaciones necesarias para el perfeccionamiento gradual de las instituciones religiosas (pese a la imposibilidad de su realización en sentido absoluto)?

\section{El reino de los fines como idea práctica}

En el segundo capítulo de la Fundamentación de la metafísica de las costumbres, Kant se refiere al tránsito de la filosofía moral popular a la metafísica moral y propone, como sabemos, diversas formulaciones del imperativo categórico. Mientras la primera fórmula prescribe la posible concordancia de la máxima subjetiva con la ley objetiva como un criterio formal para la determinación del valor moral de las acciones, la segunda fórmula establece el valor absoluto del ser humano, su valor intrínseco e incondicionado, no relativo a ningún fin ulterior: "Tanto en las acciones orientadas hacia sí mismo como en las dirigidas hacia otros seres racionales el hombre ha de ser considerado siempre al mismo tiempo como un fin" (GMS, AA 4: 428).

Este valor absoluto es inherente al ser humano en virtud de su naturaleza racional: es, en efecto, su capacidad de actuar según máximas $-\mathrm{y}$ no según la mera determinación de leyes naturales - aquello que le confiere su dignidad especial, elevando su valor por encima de aquel propio de todo 
ser natural y de cualquier objeto en general. ${ }^{5}$ Kant señala que el valor de la humanidad como fin en sí establece "la máxima condición restrictiva de las acciones de cada hombre" (GMS, AA 4: 430), esto es, determina hasta dónde se extiende la capacidad de cada uno de actuar libremente: las acciones individuales no pueden vulnerar bajo ninguna condición el valor absoluto de la persona humana. ${ }^{6}$ La dimensión intersubjetiva de la moralidad se halla, pues, referida en esta fórmula, la del hombre como fin en sí. La concepción de la humanidad como algo que posee un valor intrínseco se vincula, a su vez, con la idea de una voluntad racional que posee la capacidad de legislar universalmente. ${ }^{7}$ La dimensión intersubjetiva anunciada en la segunda formulación del imperativo conduce, en el desarrollo de la argumentación kantiana, a la formulación del principio de una voluntad racional universalmente legisladora, una voluntad autónoma; noción a partir de la cual Kant deriva, finalmente, la idea de un reino de los fines, entendido como una comunidad de seres racionales bajo leyes morales universales (GMS, AA 4: 433).

Kant señala que esta idea de un reino de los fines es 'fructífera': aún cuando se trate de una noción que hace referencia a una comunidad ideal, ella establece un principio vinculante para la razón práctica que asume como un deber incondicionado la realización de semejante reino (GMS, AA 4: 433). ${ }^{8}$

\footnotetext{
${ }^{5}$ La dignidad o valor intrínseco de la humanidad reside, en términos generales, en el carácter racional de los seres humanos y en su capacidad de proponerse fines; sin embargo, no hay acuerdo entre los comentaristas acerca del carácter específicamente moral de tales fines. Korsgaard señala que es la mera capacidad de establecer fines en general aquello que confiere dignidad a la humanidad (1996: 110111). Allison considera que tal dignidad está ligada a la cualidad moral del ser humano, esto es, a su facultad racional práctica (2011: 216-217). Wood coincide con Allison respecto de este punto: "This radical egalitarianism, grounded in the conception of every human being as a rationally self-governing agent, is the most fundamental idea in Kantian ethics [...]. If being an end in itself constitutes the worth of humanity - in the technical Kantian sense, which is the capacity to set ends according to reasonthen having dignity constitutes the worth of personality, which is the capacity to give oneself moral laws and obey them" (2008: 94). Más allá de estas discrepancias entre los intérpretes, el punto decisivo es que la concepción del ser humano como fin en sí, como algo que posee un valor incondicionado, constituye un contenido fundamental de la doctrina ética kantiana: la idea es que los fines relativos no pueden dar fundamento a un imperativo categórico; solo algo que posea un valor intrínseco y absoluto puede establecer una obligación absolutamente incondicionada.

${ }^{6}$ Para un estudio detallado del concepto kantiano de dignidad humana y sus proyecciones jurídicopolíticas, v. Beade (2016a: 27-42).

${ }^{7}$ Señala Korsgaard que en nuestro carácter de seres racionales, dotados de un valor absoluto, podemos representarnos como miembros de una comunidad ideal en la que cada uno se respeta a sí mismo y a los demás como seres capaces de auto-legislarse, seres que poseen la capacidad de darse fines de manera individual y colectiva (1997: vii, ss).

${ }^{8}$ Para un análisis del carácter normativo que Kant asigna a las ideas de la razón práctica, v. Beade (2014a: 473-492).
} 
El 'principio supremo de la moralidad', i.e., el principio de la autonomía de la voluntad, no se deduce así directamente de la primera fórmula del imperativo, sino de la segunda, de la fórmula del hombre como fin en sí mismo. La idea de la absoluta dignidad del ser humano conduce, en efecto, a la figura del reino de los fines, cuyos miembros no solo se sujetan a leyes morales, sino que son además legisladores. Nuestra capacidad de establecer los principios o leyes que nos determinan a actuar, pero de tal modo que estas leyes no valgan únicamente para nuestra acción individual, sino que puedan arrogarse una validez universal, es precisamente lo que nos confiere dignidad, lo que nos dota de un valor intrínseco e incondicionado. No es, pues, la mera sujeción a leyes morales lo que hace a la persona digna o sublime, sino el sometimiento a unas leyes que ella se dicta a sí misma. ${ }^{9}$ En tal sentido observa Kant, en el Tercer capítulo de la Fundamentación, que "una voluntad libre y una voluntad bajo leyes morales son exactamente lo mismo" (GMS, AA 4: 446), observación fundada en una concepción de la libertad como autonomía, i.e., como la facultad de la voluntad de darse leyes a sí misma y de obedecerlas.

El reino de los fines es caracterizado como un reino inteligible, constituido por todos los seres humanos en tanto sujetos racionales y autónomos, reino que no es real, sino posible, lo cual resulta suficiente para los intereses de la razón práctica (GMS, AA 4: 438). Para que semejante reino se tornara real, los hombres deberían actuar en todo caso según máximas acordes con el mandato de la ley objetiva; pero esto, como sabemos, no es posible en razón de una dialéctica natural, inevitable, entre el deber y las inclinaciones. Esta comunidad, representada como un mundo inteligible, surge, pues, como una idea, una representación, toda vez que consideramos a los seres humanos como noúmenos, es decir, no como seres fenoménicos, sino como agentes cuya causalidad se inscribe en un orden trascendente al orden temporal. ${ }^{10}$ Es en tanto sujetos racionales, libres, autónomos, que los

\footnotetext{
${ }^{9}$ En este sentido señala Kant que "aún cuando bajo el concepto del deber pensamos una sumisión bajo la ley, al mismo tiempo nos representamos merced a ello una cierta sublimidad y dignidad en aquella persona que cumple todos sus deberes. Pues ciertamente no hay sublimidad alguna en esa persona como sometida a la ley moral, pero sí la hay en tanto que al mismo tiempo es legisladora de dicha ley y sólo por ello esta sometida a ella [... la dignidad de la humanidad consiste justo en esa capacidad para dar leyes universales, aunque con la condición de quedar sometida ella misma a esa legislación" (GMS, AA 4: 439-440).

${ }^{10}$ Para un breve análisis de la concepción kantiana de la libertad en tanto tipo de causalidad no temporal, no regida por leyes mecánicas, remitimos al trabajo Beade (2013: 100-126). Un estudio más detallado de esta temática puede hallarse en Watkins (2005). V. nota al pie 15.
} 
individuos integran esta comunidad, o aspiran a integrarla, en la medida en que se esfuerzan por realizar acciones cuyas máximas concuerden con el mandato incondicionado de la ley moral.

Esta breve reconstrucción permite constatar que en la noción de un reino de los fines se conjugan conceptos fundamentales de la doctrina ética kantiana, a saber, el concepto del ser racional como fin en sí, la noción de dignidad humana y el principio de autonomía. Si aquella noción revela una dimensión intersubjetiva o comunitaria de dicha doctrina, parece posible rechazar su caracterización como una doctrina exclusivamente abocada a la dimensión individual de la moralidad.

No solo la idea de un reino de los fines expresa esta dimensión comunitaria, sino la propia noción de dignidad humana. En efecto, la dignidad de la persona es, para Kant, el fundamento último de los deberes, tanto de los llamados deberes para consigo mismo, como de los deberes para con otros. Así señala, en La metafísica de las costumbres:

La humanidad misma es una dignidad [Die Menschheit selbst ist eine Würde] porque el hombre no puede ser utilizado únicamente como medio por ningún hombre (ni por otros, ni siquiera por sí mismo), sino siempre a la vez como fin, y en esto consiste precisamente su dignidad (la personalidad), en virtud de la cual se eleva sobre todos los demás seres del mundo que no son hombres y que sí pueden utilizarse, por consiguiente, se eleva sobre todas las cosas. Así pues, de igual modo que él no puede autoenajenarse por ningún precio (lo cual se opondría al deber de la autoestima), tampoco puede obrar en contra de la autoestima de los demás como hombres, que es igualmente necesaria (MS, AA 6: 462). ${ }^{11}$

El deber de la autoestima - como deber del hombre para consigo mismo - tiene como correlato un deber para con otros, a saber, el deber de no realizar acciones que pudiesen impedir, en otros, su autoestima. Todo ser humano no solo tiene derecho a exigir de otros que lo respeten, que no lo utilicen jamás como un mero medio para la satisfacción de sus fines propios,

${ }^{11}$ Citamos la traducción española de La metafisica de las costumbres [Die Metaphysik der Sitten] (1994). 
sino que puede arrogarse además el derecho a no ser impedido en aquello que resulte necesario para su propia autoestima. ${ }^{12}$

Podría decirse que esta concepción del hombre como fin en sí, como un ser que posee dignidad, no solo expresa una dimensión intersubjetiva de la moralidad, sino que introduce además un elemento material en el marco de la ética kantiana, un elemento que no puede ser traducido a términos puramente formales. Esto permitiría rechazar la otra objeción antes mencionada: aquella referida a un presunto formalismo. En efecto, la noción de dignidad parece situarnos más allá del principio formal de una posible universalización de las máximas, establecido en el marco de la primera formulación del imperativo, por cuanto alude a aquello que deber ser universalmente reconocido como válido, aquello que posee un valor intrínseco y absoluto, esto es, la humanidad. De esa concepción emanan deberes éticos específicos y, en tal sentido, cabe sostener la presencia de un componente material en el marco de la ética formal kantiana. En síntesis: pese a las observaciones de Kant referidas al carácter equivalente de las diversas formulaciones del imperativo, ${ }^{13}$ la noción de la humanidad como fin en sí invoca un contenido que no se halla presente de manera explícita en la primera fórmula, noción que no solo establece la condición restrictiva de toda acción humana en general, sino que da lugar además a deberes específicos. ${ }^{14}$

\footnotetext{
${ }^{12}$ Toda persona debe respetarse a sí misma y a otras por iguales razones: el respeto mutuo que las personas deben profesarse se funda en la dignidad inherente al género humano. Respetar la dignidad del otro no impide, desde luego, reprobar sus acciones; pero aún cuando se denostase cierta acción, no podría despreciarse a quien la ha realizado en aquello que atañe a su condición humana, y esto vale incluso para quien, a causa de sus acciones, se haya hecho indigno de la humanidad en su propia persona.

${ }_{13}$ Stratton-Lake considera que Kant no establece claramente la conexión entre las diversas formulaciones del imperativo: por un lado, caracteriza la primera fórmula como 'forma' por oposición a las otras como 'materia' o 'determinación' de la primera; por otro lado, sugiere que cada una de las fórmulas incorpora en sí a las otras, mientras que afirma, por otra parte, que las fórmulas segunda y tercera permiten aproximar la razón a la intuición, es decir, posibilitan una mejor comprensión de la primera fórmula, de carácter abstracto y formal (1993: 317, 331). El autor coincide con O’Neill en que las diversas formulaciones del imperativo deben ser interpretadas como aproximaciones a un mismo principio considerado desde perspectivas diversas (1989: 143). Ahora bien, respecto de este punto, coincidimos con Paton, quien indica que la segunda fórmula no puede entenderse como equivalente de la primera, por cuanto aporta cierto contenido que no se halla presente en la fórmula de la ley universal, a saber, la concepción del hombre como fin en sí. Tal concepción no solo introduce un componente material en la ética kantiana, sino que incluso puede ser considerada como fundamento del imperativo categórico (Paton 1967: 170)

${ }^{14}$ El cultivo de los llamados deberes de virtud es identificado, por Kant, como un fin que la razón se representa como deber y que no alude ya a la mera forma de la moralidad, sino a su contenido: "La virtud, entendida como conformidad de la voluntad con todo deber [...] es sólo, como todo lo formal una y la misma. Pero atendiendo al fin [...] es decir, a aquello (material) que debemos proponernos
} 
Ahora bien, si la noción de dignidad humana aporta un elemento material en el tratamiento kantiano de la moralidad, y la noción de reino de las fines introduce un elemento intersubjetivo, comunitario, lo cierto es que en la Fundamentación no hallamos, sin embargo, mayores precisiones respecto de una posible dimensión social del reino de los fines. Este mundo es presentado allí como una idea práctica, la idea de un mundo inteligible, que resulta a partir de la adopción de cierta perspectiva: la del hombre como ser nouménico. ${ }^{15}$ Es en el escrito de 1793, La religión dentro de los límites de la mera razón, donde encontramos importantes referencias a lo que podría ser caracterizado como una suerte de correlato histórico de esta idea del reino de los fines. Un breve análisis de algunos pasajes relevantes para el tratamiento de esta cuestión permitirá aclarar en qué sentido la comunidad ética puede ser pensada como correlato fenoménico del reino de los fines en tanto mundo inteligible.

\section{La comunidad ética como comunidad religiosa}

La investigación desarrollada en La religión se inscribe en el marco del proyecto de lo que podría denominarse una teología natural. Kant se refiere allí a la posibilidad de una religión racional pura, i.e., fundada en principios estrictamente racionales. La primera parte del escrito trata acerca del mal radical, inherente a la naturaleza humana, pero establece asimismo una originaria disposición al bien; de allí el conflicto - constitutivo en el ser humano - entre el principio bueno y el malo, cuestión que será abordada en la segunda parte del texto. Kant propone en esa parte segunda una suerte de traducción del relato bíblico al 'lenguaje de la razón', esto es, intenta hallar en la Escritura aquello que esté en armonía con los principios racionales. A partir de esta operación hermenéutica extrae lo que considera la enseñanza

\footnotetext{
como fin, puede haber más virtudes, y la obligación con respecto a la máxima de perseguirlo se llama deber de virtud; por tanto, hay muchos deberes de virtud" (MS, AA 6: 395).

${ }^{15}$ En la Crítica de la razón pura afirma Kant que es necesario pensarnos como miembros de un mundo inteligible y como poseedores de un carácter inteligible, esto es, como agentes cuya causalidad no puede ser reducida a la causalidad natural (A550-551/B578-579). El ser humano se concibe a sí mismo como agente dotado de ciertas facultades que le permiten actuar independientemente de los condicionamientos empíricos que determinan la conducta de los seres naturales inanimados y de la vida meramente animal. A partir del reconocimiento de imperativos prácticos, los sujetos racionales se representan a sí mismos como poseedores de una causalidad de la razón o causalidad libre, siendo su capacidad de apercepción - y, especialmente, su conciencia del deber- aquello que los diferencia del resto de los seres naturales (A547/B575). La conciencia del deber permite que nos situemos en un ámbito no fenoménico, inteligible, en el cual ha de ser inscripta nuestra facultad de determinación del arbitrio, esto es, nuestra libertad (v. Prol., AA 4: 354; KpV, AA 5: 94; GMS, AA 4: 453-458).
} 
fundamental del relato bíblico, a saber, que "no hay salud para los hombres si no es en el íntimo acogimiento de genuinos principios morales en su intención" ( $R G V$, AA 6: 83). El esfuerzo por buscar en la Escritura lo que armonice con lo que enseña la razón es la base de la genuina religión, la verdadera religión, aquella que se sustenta en puros principios racionales. Los relatos históricos, los rituales, no constituyen, pues, lo íntimo y esencial de la religión: conocerlos, profesarlos, observalos, no nos hace agradables a Dios (RGV, AA 6: 84).

La tercera parte del escrito establece las condiciones necesarias para el triunfo del principio bueno sobre el malo e introduce la idea de un reino de Dios sobre la tierra. En este contexto, señala Kant que las circunstancias que corrompen nuestra intención moral no residen tanto en la propia naturaleza del ser humano en cuanto existe aisladamente, sino en tanto individuo que interactúa con otros:

La envidia, el ansia de dominio, la codicia y las inclinaciones hostiles ligadas a todo ello asaltan su naturaleza [...] tan pronto como está entre hombres [wenn er unter Menschen ist], y ni siquiera es necesario suponer ya que éstos están hundidos en el mal y constituyen ejemplos que inducen a él; es bastante que estén ahí, que lo rodeen, y que sean hombres, para que mutuamente se corrompa en su disposición moral y se hagan malos unos a otros ( $R G V$, AA 6: 93-94).

Estas observaciones parecen situarnos lejos del optimismo con el que Kant celebraba la 'insociable sociabilidad' en Idea para una historia universal en sentido cosmopolita. Mientras que en el escrito de 1784 caracterizaba el antagonismo entre las tendencias sociales e insociales del ser humano como el medio del que se sirve la Naturaleza para promover el desarrollo de nuestras disposiciones, y sugería que solo en la interacción competitiva con otros cada uno logra desplegar sus disposiciones y talentos (que de otro modo permanecerían latentes), ${ }^{16}$ en el escrito sobre la religión

\footnotetext{
${ }^{16}$ De este modo se van desarrollando todos los talentos, los hombres se van ilustrando y transforman su tosca disposición natural en un discernimiento ético. Sin la insociable sociabilidad los talentos humanos quedarían ocultos en su germen. "Demos gracias a la Naturaleza por la incompatibilidad, por la envidiosa vanidad que nos hace rivalizar o incluso por el anhelo de acaparar y de dominar. El hombre quiere concordia, pero la Naturaleza sabe mejor lo que le conviene a su especie y quiere discordia" (IaG, AA 8: 21). Citamos la versión española de Idea para una Historia Universal en clave cosmopolita y otros escritos sobre Filosofia de la Historia [Idee zu einer allgemeinen Geschichte in weltbürgerlicher Absicht] (1994).
} 
los lazos sociales son identificados como el origen de la corrupción de nuestra disposición natural al bien.

Más allá de los motivos que permitan justificar o explicar estas aparentes discrepancias - vinculadas con las diversas cuestiones específicas abordadas en cada uno de estos textos-, el punto que interesa destacar es que Kant confía en que los seres humanos cuentan con los medios necesarios para contrarrestar el mal —o la disposición al mal—, tanto en su dimensión individual como social. En el escrito de 1784, la 'insociable sociabilidad' "acaba por convertirse en la causa de un orden legal", es decir, fuerza al establecimiento de leyes que permitan limitar nuestras tendencias hostiles, posibilitando así el desarrollo de nuestras disposiciones naturales ( $I a G$, AA 8: 20). En el texto de 1793, el afán de dominio, la codicia, la tendencia a rivalizar, el egoísmo y otras disposiciones a las que cabría calificar como insociables, no son identificadas ya como tendencias que promuevan el desarrollo del género humano, sino como inclinaciones que suponen un riesgo para la moralidad, en la medida en que atentan contra la primacía del principio del bien. No obstante, estas cualidades, que despliegan su potencialidad en el marco del entramado social, pueden ser moderadas, encausadas, a través de la institución de una comunidad ética [eine ethische Gesellschaft]. La institución de esta comunidad constituye, para Kant, un deber del género humano para consigo mismo, pues solo a través de ella cabe esperar la victoria del principio bueno sobre el malo.

Examinemos brevemente cómo describe Kant la comunidad ética. Ella puede existir en medio de una comunidad política. Más aún, requiere de esta como su base. Sin embargo, el principio de unión que rige en cada una de ellas es diverso: la comunidad política vincula a los individuos bajo leyes coactivas (las leyes positivas), mientras que la comunidad ética los reúne bajo leyes no coercitivas, las leyes de virtud ( $R G V$, AA 6: 95). No es esta la única diferencia entre ambas: la comunidad política, producto del contrato, permite superar el estado de naturaleza; pero en una comunidad política ya existente los ciudadanos se encuentran en un estado de naturaleza ético y están autorizados a permanecer en él, ya que nadie puede ser forzado a integrar una comunidad ética: "esta última ya en su concepto lleva consigo la libertad con 
respecto a toda coacción" ( $R G V$, AA 6: 95). ${ }^{17}$ Solo en tanto reúne a individuos libres y no se halla sujeta a coacción externa alguna, la comunidad ética hace posible el triunfo del principio bueno sobre el malo. En cuanto a la relación entre dicha comunidad y el Estado que la acoge, aquella no puede interferir con las leyes civiles, ni exigir a sus miembros la realización de acciones que infringiesen las leyes del derecho político.

A los fines de interpretar correctamente estas observaciones, debe ante todo señalarse que la comunidad ética solo es posible, para Kant, bajo la forma de una iglesia. Se trata, en efecto, de una comunidad ético-religiosa que no se identifica con ninguna iglesia particular, sino que es concebida como una comunidad de carácter universal. Se indicó ya que la pertenencia del individuo a la comunidad ética no puede ser resultado de una coacción externa: no puede imponerse al individuo que integre dicha comunidad, sino que su pertenencia a la misma solo puede responder a un deber interno, un deber moral que, según se ha señalado, el género humano tiene para consigo mismo:

Tenemos, pues, aquí un deber de índole peculiar, no un deber de los hombres para con hombres, sino del género humano para consigo mismo. Todo género de seres racionales está en efecto determinado objetivamente, en la idea de la Razón, a un fin comunitario, a saber: a la promoción del bien supremo como bien comunitario $(R G V, \mathrm{AA} 6: 98)$.

El bien supremo, caracterizado por Kant, de manera recurrente, como la concordancia entre felicidad y virtud ( $K r V$ A804ss/B832ss; $K p V$, AA 5: 43; $K U$, AA 5: 569), ${ }^{18}$ es definido aquí como un bien no asequible al individuo, un bien que exige de toda una comunidad orientada a un fin único, a saber, a la 'república universal según leyes de la virtud'. En la idea de comunidad

\footnotetext{
${ }^{17} \mathrm{Si}$ bien un gobernante puede entrever las ventajas que conlleva la institución de una comunidad ética en su comunidad política (pues allí donde las leyes jurídicas no alcancen para imponer la obediencia podrían ser suplidas por leyes de virtud), no puede instituir, sin embargo, una comunidad ética a través de medios coactivos: semejante acción amenazaría no solo la existencia de una comunidad ética, sino que pondría en riesgo a la propia comunidad política.

${ }^{18}$ Mientras que el supremo bien está vinculado con la comunidad ética, tal como se la describe en $R G V$, el supremo bien político se conecta con la noción de un derecho cosmopolita y de una federación de Estados libres (Allison 2009: 44; Yovel 1980: 274). Para un estudio de la conexión entre el supremo bien, la filosofía moral kantiana y su filosofía de la religión, v. Smith 1984; Engstrom 1992; Reath 1998; Mariña 2000.
} 
ética hallamos, pues, un nuevo registro de la dimensión intersubjetiva de la moralidad anunciada en la noción de un reino de los fines.

Ahora bien, puede resultar llamativo el hecho de que esta dimensión comunitaria de la moral, tal como se la aborda en La religión, conduzca a la idea de una comunidad de carácter religioso. En efecto, sostiene Kant que "el concepto de una comunidad ética es el concepto de un pueblo de Dios bajo leyes éticas" ( $R G V$, AA 6: 99). En el marco de esta comunidad, los deberes éticos, originados en la razón práctica en cuanto deberes internos, son a la vez representados como mandamientos divinos. De allí que la comunidad ética suponga la representación de un Dios como soberano moral del mundo. La comunidad ética, declara Kant, solo podrá ser realizada bajo la forma de una iglesia. Bajo el concepto de iglesia se entiende aquí una unión entre seres humanos que concuerda, o busca concordar, con el ideal de una comunidad ética sometida a una legislación moral divina. La iglesia, así entendida, es universal, única, trasciende la diversidad de los credos históricos particulares; en virtud de ello, se halla libre de toda superstición, sus motivos e intenciones son puramente morales. Por otra parte, en esta comunidad ético-religiosa no existen jerarquías, sino que se da una relación libre y equitativa entre todos sus miembros. ${ }^{19}$ La comunidad ética es aquella que se erige sobre una fe religiosa pura, es decir, racional. No exige la sujeción a autoridad personal alguna, sino solo una conducta moralmente buena: el servicio de Dios se limita a aquí a la promoción de la virtud moral.

Cabría afirmar, a partir de las observaciones precedentes, que el tránsito ineludible de la ética (en su dimensión intersubjetiva) a la religión, no es sino un tránsito hacia una forma de religión que, en última instancia, no es más que una ética. La idea de Dios implicada en la noción de comunidad ética es una idea de la razón práctica, cuya representación resulta exigida por el deber de promover el bien supremo:

Puesto que el hombre no puede realizar él mismo la idea del bien supremo ligada inseparablemente a la intención moral pura [...] y, sin embargo, encuentra en sí el

\footnotetext{
${ }^{19}$ Señala Kant, más adelante, que "La degradante distinción entre laicos y clérigos cesa, y la igualdad surge de la verdadera libertad, sin anarquía, porque cada uno obedece a la ley (no estatutaria) que él mismo se prescribe, pero que ha de considerar también al mismo tiempo como la voluntad — revelada a él mediante la razón - del soberano del mundo, el cual liga invisiblemente a todos bajo un gobierno comunitario en un Estado que pobremente era de antemano representado y preparado a través de la iglesia visible" (RGV, AA 6: 122).
} 
deber de trabajar en ello, se encuentra conducido a creer en la cooperación $u$ organización de un soberano moral del mundo [...]. Esta idea de un soberano moral del mundo es una tarea para nuestra Razón práctica ( $R G V$, AA 6: 139-140).

La verdadera religión -i.e., la religión racional, situada más allá de la diversidad de iglesias históricas - no contiene misterios, ni exige el cumplimiento de rituales. Kant observa que los hombres suelen confundir la religión con la fe eclesial, y así afirman pertenecer a tal o cual religión, sin comprender que ésta, en sentido estricto, difiere de toda fe estatutaria. Lo esencial de la genuina religión es "el cumplimiento de todos los deberes humanos como mandamientos divinos" ( $R G V$, AA 6: 110). Esta religión pura no necesita determinar un concepto del ser divino: "Para nosotros no se trata tanto de saber qué es Dios en sí mismo (su naturaleza), sino de saber qué es para nosotros como ser moral" (RGV, AA 6: 139).$^{20}$

Si atendemos a la relación entre la religión racional universal y las iglesias históricas particulares, cobra relevancia una dimensión que hasta el momento no ha sido mencionada, a saber, la historia, entendida como el escenario en el cual se juega la posibilidad de un tránsito progresivo de las religiones históricas hacia la religión racional única. Kant sugiere, en $L a$ religión, que la fe eclesial puede ser considerada como la forma histórica bajo la cual nos aproximamos gradualmente a una fe religiosa pura, pero se trata simplemente de un medio del cual debemos, finalmente, prescindir. ${ }^{21}$ Llegados a este punto, las reflexiones kantianas acerca de la religión se inscriben en un marco conceptual más amplio: su idea de progreso, su concepto de ilustración, ${ }^{22}$ su concepción normativa de la esperanza. ${ }^{23}$ En tal

\footnotetext{
${ }^{20}$ Bajo el giro expresivo que alude a Dios como ser moral, o a los deberes humanos como mandatos divinos, Kant expresa la imposibilidad de una determinación teórica -i.e., de un conocimiento objetivo- del ser divino, tesis consecuente con la determinación de los límites del conocimiento establecida en la Critica de la razón pura.

${ }^{21}$ Señala Herrero que la historia de la iglesia, considerada desde la perspectiva y los intereses de la razón, no es sino una historia de la desaparición progresiva de la iglesia visible, en su transición hacia una iglesia inteligible universal (1975: 266). En términos generales, coincido con las observaciones formuladas por el autor en relación a la filosofía de la historia de la religión, tal como aparece esbozada en el escrito de 1793.

${ }^{22}$ Kant expone su concepto de ilustración en su escrito de 1784, Contestación a la pregunta: Qué es la Ilustración [Beantwortung der Frage: Was ist Aufklärung?], texto en el que se refiere a las condiciones (tanto individuales como políticas) para el progreso del género humano. El libre uso público de la razón será identificado como una condición sine qua non de dicho progreso. Para un estudio detallado de esta temática, v. Beade (2014b: 376ss; 2017: 138-153).

${ }^{23}$ Desde una perspectiva kantiana, la esperanza en el progreso es una esperanza racional, más aun, un
} 
sentido, la filosofía kantiana de la religión podría ser interpretada como parte integral de su filosofía de la historia.

A propósito de esta última, se ha dado una intensa discusión entre los intérpretes en relación al carácter teórico, o bien práctico, de la 'historia filosófica', discusión que puede aportar algunas claves interesantes para pensar la filosofía kantiana de la religión. Mientras algunos comentaristas enfatizan la dimensión teórica de las reflexiones histórico-filosóficas desarrolladas en Idea para una Historia Universal en clave cosmopolita (Wood 2006: 245-247), otros destacan su dimensión eminentemente práctica o normativa (Lindstedt 1999: 135ss; Flikschuh 2006: 384ss). La dimensión teórica estaría vinculada con la intención de hallar un principio de unidad sistemática en el desarrollo histórico, un hilo conductor, una idea que permitiese inteligir el sentido unitario de dicho desarrollo (Kleingeld 2009: 175-176; Wood 2006: 245-249). ${ }^{24}$ La dimensión práctica de la 'historia filosófica' se daría, por su parte, en relación con los fines a los que se orienta - desde la perspectiva de Kant - la historia humana, fines de carácter jurídico-político, tales como la constitución republicana, el derecho cosmopolita y la paz perpetua (Allison 2009: 24-25; Ameriks 2009: 55). Esta orientación de los sucesos históricos hacia la realización de ciertos fines políticos no agota la dimensión práctica de la 'historia filosófica', ya que dicha dimensión se hace patente, a su vez, en la tesis que sostiene que debemos confiar en el progreso histórico, ya que solo bajo tal condición el progreso será factible (Beade 2016b: 71-84; Rodríguez Aramayo 2001: 53ss). ${ }^{25}$ Describir la historia como un proceso orientado a ciertos fines políticos-jurídicos contribuye de manera decisiva a la realización de tales

deber moral, por cuanto está fundada en exigencias de la razón práctica (Lindstedt 1999: 145). No se trata de un postulado ingenuo, de un optimismo carente de fundamentos, porque es la razón en su uso práctico aquello que nos exige representarnos ciertos fines como deberes. La esperanza en el progreso se halla profundamente ligada a nuestras disposiciones morales (Kuhen 2009: 91).

${ }^{24}$ Guyer ha señalado que la concepción teleológica de la historia en tanto proceso orientado a un fin intencionado por la Naturaleza — concepción esbozada en 1784 en Idea para una historia universalhallaría su formulación teórica definitiva en las investigaciones desarrolladas posteriormente en la Crítica de la facultad de juzgar (2006: 347-34).

${ }^{25}$ La filosofía de la historia o 'historia filosófica', como Kant la concibe en sus escritos, no se inscribe en el ámbito del conocimiento, no proporciona ningún saber objetivo acerca del desarrollo histórico, sino que provee herramientas conceptuales orientadas a la promoción del progreso moral y político del género humano (Booth 1983: 63; Kaulbach 1975: 67). 
fines, impulsando las transformaciones necesarias para una constante aproximación al republicanismo y al derecho cosmopolita. ${ }^{26}$

Si la filosofía kantiana de la historia se asienta en la idea de un progreso gradual del género humano, también en el plano religioso Kant confía en un avance hacia una forma de religión depurada de elementos estatutarios, históricos, contingentes, i.e., confía en el progreso hacia una religión racional pura. La filosofía kantiana de la religión —entendida como una filosofía de la historia de la religión - se orienta, no ya hacia un fin político-jurídico, sino hacia un fin moral, a saber: el progreso de la fe eclesial hacia la religión racional universal, fundada exclusivamente en principios de la razón práctica. En pocas palabras: si la historia universal del género humano puede ser (filosóficamente) interpretada como un proceso orientado a la realización progresiva de ciertas ideas de la razón, la historia de la religión puede ser concebida, de manera análoga, como el tránsito gradual desde la fe eclesiástica a la fe racional pura.

\section{Consideraciones finales}

La tercera de las célebres preguntas kantianas, ¿qué puedo conocer?, ¿qué debo hacer?, ¿qué me cabe esperar?, puede ser respondida, indudablemente, a partir de las reflexiones histórico-filosóficas kantianas. Sin embargo, también cabría responder a esa pregunta a partir de las reflexiones que el filósofo dedica a la cuestión la religión y a las que he hecho referencia en estas páginas. En efecto, a la pregunta qué me cabe esperar podría responderse: el bien supremo, un bien que puede ser pensado, en términos morales, como la concordancia entre felicidad y virtud; o en términos político-jurídicos, como una aproximación a la constitución republicana y al derecho cosmopolita; o en términos religiosos, como la consumación de una religión racional. La religión no ofrece respuesta alguna a problemas epistémicos, no se inscribe en el plano del conocimiento, ni prescribe principios que determinen a la voluntad en sus acciones éticas: la religión

\footnotetext{
${ }^{26}$ En tal sentido sostiene Bittner que la filosofía "ayuda a la historia"; algo similar cabría afirmar acerca de la idea de una comunidad ética, el reino de los fines y la religión racional pura (2009: 231ss). Diversos intérpretes señalan que la relación entre la historia empírica y la historia a priori (o historia filosófica), y la cuestión de una posible realización empírica de las ideas de la razón, constituyen tópicos fundamentales abordados por Kant en Idea para una historia universal (Yovel 1980: 278ss; Kleingeld 2006: xxii; Pinkard 2009: 218).
} 
pertenece al ámbito de aquello que puede esperarse, esto es, al ámbito propio de la esperanza. ${ }^{27}$

La esperanza es, ante todo, para Kant, esperanza en el progreso del género humano, y el fundamento último de toda esperanza es la razón, en dos sentidos: en primer lugar, la facultad racional inherente al ser humano lo hace perfectible, y esta perfectibilidad permite confiar en un avance hacia instituciones político-jurídicas orientadas a una ampliación progresiva de la libertad y la igualdad, principios fundamentales del republicanismo; en segundo lugar, la esperanza es resultado de una exigencia de la razón práctica, de un mandato moral. En tal sentido señala Kant:

Se me permitirá, pues, admitir que, como el género humano se halla en continuo avance por lo que respecta a la cultura, que es su fin natural, también cabe concebir que progresa a mejor en lo concerniente al fin moral de su existencia, de modo que este progreso sin duda será a veces interrumpido, pero jamás roto. No tengo necesidad de demostrar esta suposición; es el adversario de ella quien ha de proporcionar una prueba. Porque yo me apoyo en un deber para mí innato, consistente en que cada miembro de la serie de generaciones [...] actúe sobre la posteridad de tal manera que ésta se haga cada vez mejor [...]. Ahora bien, por más dudas que de la historia quepa extraer contra mis esperanzas [...], me asiste pese a todo la posibilidad de no trocar el deber [...] por la regla de prudencia consistente en no dedicarse a lo impracticable [...]; por incierto que me resulte y que me siga resultando siempre si cabe esperar lo mejor para el género humano, esto no puede destruir, sin embargo, la máxima -ni, por tanto, la necesidad de presuponerla con miras prácticas- de que tal cosa es factible (TP, AA 8: 308-309). ${ }^{28}$

\footnotetext{
${ }^{27}$ En tal sentido señala O'Neill: "The reasons that Kant offers interpret religious trust or commitment fundamentally as a mode of hope: religious faith cannot be a matter of knowledge, and must be a matter of taking a hopeful view of human destiny" (1996: 281). Como señala acertadamente la autora, no resulta claro si la esperanza que la razón demanda es pensada por Kant como una esperanza en el progreso político, en el progreso moral, o bien en un progreso de carácter religioso: "Yet at many points Religion within the Limits of Reason Alone is less definite than the Critique of Practical Reason about the form that hope, even hopes for the highest good, must take. Often the text does not make it clear whether the hope that makes sense of our aspirations to morality is this-worldly or other-worldly; sometimes it is not obvious whether the hope is religious or historical" (1996: 292-293). Ahora bien, más allá del contenido específico que deba atribuirse al bien supremo, puede afirmarse que se trata aquí de una esperanza en el progreso del género humano, progreso cuya factibilidad está ligada a nuestra capacidad racional: "Reasoned religion is, after all, to answer the third question that interests human reason, the question of human destiny, which asks not "What must I hope?" but more openly "What may I hope?" In asking this question Kant leaves open not only various ways in which identifiably religious hopes for human destiny may be articulated, but also the possibility that hopes for human destiny may be articulated in social, political, and historical, this-worldly terms rather than in otherworldly terms" (1996: 303).

${ }^{28}$ Citamos la traducción española de Teoría y práctica [Über den Gemeinspruch: Das mag in der Theorie richtig sein, taugt aber nicht für die Praxis] (1993).
} 
Los datos que podrían obtenerse a partir de una consideración de los sucesos históricos - como datos probatorios de una ausencia de progresoresultan absolutamente irrelevantes, pues en la consideración filosófica de la historia no se trata de lo que es (o de lo que fue) sino únicamente de lo que debe ser, esto es, de lo que la razón se representa como exigencia. Dicha consideración es, por consiguiente, de carácter esencialmente normativo. Debemos suponer que es factible el progreso jurídico-político, y debemos asumir, del mismo modo, que es factible un avance de la religión hacia la religión racional universal, depurada de todo fanatismo y toda superstición. Esto no implica afirmar que el supremo bien moral, el supremo bien político, y el supremo bien en sentido religioso, puedan ser plenamente realizados; sino que significa que la razón nos exhorta a confiar en un avance progresivo, asintótico, hacia estos fines cuya realización nos impone como un deber y nos compele así a actuar de manera tal que ese avance resulte factible. ${ }^{29}$

Cabría preguntar, finalmente, en qué sentido es posible, entonces, pensar la religión racional pura como superadora de las religiones estatutarias. Desde la perspectiva asumida por Kant, la ventaja insoslayable de una religión fundada en la razón es, indudablemente, su liberación de todo fanatismo: "La ilusión religiosa fanática es la muerte moral de la razón, y sin la razón no puede en absoluto tener lugar una religión, en cuanto que ésta, como toda moralidad en general, ha de ser fundada en principios" ( $R G V$, AA 6: 175). Haciendo referencia a aquellos que anteponen la observancia de rituales a la buena conducta de vida, señala Kant, "cuánto importa, cuando se quiere ligar dos cosas buenas, el orden en que se las liga" ( $R G V$, AA 6: 179). La moral y la religión se hallan indisolublemente vinculadas; pero se trata aquí de un vínculo dispar, asimétrico: la moral ocupa el lugar fundamental en cuanto fuente $u$ origen de la genuina creencia religiosa. Y si bien la moral se orienta de manera ineludible a la religión, esta última retorna, en cierto sentido, a la moral, toda vez que se la comprende como una religión racional pura.

En el Prólogo a La religión, Kant declara que "una religión que sin escrúpulos declara la guerra a la razón, a la larga no se sostendrá contra ella [eine Religion, die der Vernunft unbedenklich den Krieg ankündigt, wird es

\footnotetext{
${ }^{29}$ La iglesia universal, como comunidad ideal, es inmutable en su constitución, más allá de ciertos ordenamientos históricos bajo los cuales pueda eventualmente realizarse; ordenamientos que resultan necesariamente contingentes, pero que pueden ser pensados como instancias en un proceso de aproximación gradual a la fe racional pura.
} 
auf die Dauer gegen sie nicht aushalten]" (RGV, AA 6: 10). La creencia religiosa a la que la razón nos exhorta se limita a la esperanza en la posibilidad de un bien supremo en el mundo. En el plano religioso, la razón exige el abandono del fanatismo, de la superstición, del dogmatismo. Solo bajo tal condición la religión racional pura podrá dar lugar a una comunidad ética, a un reino de los fines, que integrará a los seres humanos en tanto seres racionales, capaces de determinar su voluntad según leyes prácticas universales. Como miembros de esa iglesia invisible o iglesia universal, los individuos no se hallarán sujetos a autoridad eclesiástica alguna, sino que constituirán una comunidad equitativa en la que cada uno se obedece a sí mismo al obedecer la ley moral objetiva.

En este punto, convergen, pues, la idea de un reino de los fines y la noción de una comunidad ética: podemos — y más aún: debemos - esperar que el reino de los fines se plasme históricamente como una iglesia universal, pero esta no será, finalmente, más que una comunidad moral despojada de todo componente ritual. Los lazos comunitarios que vinculen a los individuos en cuanto miembros de dicha comunidad no serán, pues, en última instancia, sino los principios de la razón pura práctica.

\section{Referencias}

ALLISON, H.: "Teleology and history in Kant: the critical foundations of Kant's philosophy of history", en RORTY, A. O.; SCHMIDT, J. (eds.): Kant's Idea for a Universal History with a Cosmopolitan Aim. A Critical Guide, Cambridge, Cambridge University Press, 2009. : Kant's Grounwork for the Metaphysics of Morals. A Comentary, New York, Oxford University Press, 2011.

AMERIKS, K.: "The purposive development of human capacities", en RORTY, A. O.; SCHMIDT, J. (eds.): Kant's Idea for a Universal History with a Cosmopolitan Aim. A Critical Guide, Cambridge, Cambridge University Press, 2009.

BEADE, I.: "En torno al sentido epistémico de la distinción crítica entre lo sensible y lo inteligible. Un análisis de la doctrina kantiana del doble carácter”, Studia Kantiana 14 (2013) 100-126.

: "Acerca del carácter regulativo de las ideas de la razón en el marco de la doctrina jurídico-política kantiana”, Revista Portuguesa de Filosofía 70 (2014a) 473-492. 
: "Libertad y orden en la Filosofía política kantiana. Acerca de los límites del uso público de la razón en El conflicto de las Facultades", Isegoría 50 (2014b) 371-392.

: "Acerca del concepto de dignidad humana en la filosofía kantiana: del hombre como fin en sí mismo al hombre como ciudadano del mundo", Revista de Estudios Kantianos 1 (2016a) 27-42.

: "Some Remarks on Kant's Concept of an a priori History", Studia Kantiana 22 (2016b) 71-84.

: "Ilustración y publicidad en la doctrina política kantiana", en ÓRDENES, P.; ALEGRÍA, D. (eds.): Kant y los retos prácticomorales de la actualidad, Madrid, Tecnos, 2017.

BITTNER, R.: "Philosophy helps history", en RORTY, A. O.; SCHMIDT, J. (eds.): Kant's Idea for a Universal History with a Cosmopolitan Aim. A Critical Guide, Cambridge, Cambridge University Press, 2009.

BOOTH, W.: "Reason and History: Kant's Other Copernican Revolution", Kant- Studien 74 (1983) 56-71.

ENGSTROM, S.: "The Concept of the Highest Good in Kant's Moral Theory", Philosophy and Phenomenological Research 52, 4 (1992) 747-780.

HERRERO, F.: Religión e historia en Kant, Madrid, Gredos, 1975.

KANT, I.: Kants gesammelte Schriften, vol. I-IX, Berlin, Herasugegeben von der Königlich Preussischen Akademie der Wissenschaften, 1902ss. : Teoría y práctica [Über den Gemeinspruch: Das mag in der Theorie richtig sein, taugt aber nicht für die Praxis, 1793], trad. PALACIOS, J. M.; PÉREZ LÓPEZ, F.; RODRÍGUEZ ARAMAYO, R., Madrid, Tecnos, 1993.

: La metafisica de las costumbres [Die Metaphysik der Sitten, 1796], trad. CORTINA ORTS, A.; CONILL SANCHO, J., Madrid, Tecnos, 1994.

: Idea para una Historia Universal en clave cosmopolita y otros escritos sobre Filosofía de la Historia [Idee zu einer allgemeinen Geschichte in weltbürgerlicher Absicht, 1784], trad. ROLDÁN, C.; RODRÍGUEZ ARAMAYO, R., Madrid, Tecnos, 1994.

: La religión dentro de los limites de la mera razón [Die Religion innerhalb der Grenzen der bloßen Vernunft, 1793], trad. MARTÍNEZ MARZOA, Madrid, Alianza, 1995.

: Prolegómenos a toda metafisica futura que haya de poder 
presentarse como ciencia [Prolegomena zu einer jeden künftigen Metaphysik, die als Wissenschaft wird auftreten können, 1793], trad. CAIMI, M., Madrid, Istmo, 1999.

: Fundamentación para una metafísica de las costumbres [Grundlegung zur Metaphysik der Sitten, 1785], trad. RODRÍGUEZ ARAMAYO, R., Madrid, Alianza, 2005.

: Crítica de la razón pura [Kritik der reinen Vernunft, 1781/ 1787], trad. CAIMI, M., Buenos Aires, Colihue, 2007.

: Crítica de la razón práctica [Kritik der praktischen Vernunft, 1788], trad. RODRÍGUEZ ARAMAYO, R., Madrid, Alianza, 2007.

: Contestación a la pregunta: Qué es la Ilustración [Beantwortung der Frage: Was ist Aufklärung?, 1784], trad. RODRÍGUEZ ARAMAYO, R., Madrid, Alianza, 2013.

KAULBACH, F.: "Welchen Nutzen gibt Kant der Geschichtsphilosophie?", Kant-Studien 66 (1975) 65-84.

KERSTEIN, S.: Kant's Search for the Supreme Principle of Morality, Cambridge, Cambridge University Press, 2002.

KLEINGELD, P.: "Kant on Politics, Peace, and History", en KLEINGELD, P. (ed.): Toward Perpetual Peace and other Writings on Politics, Peace and History, New York, Yale University Press, 2006.

: "Kant's changing cosmopolitanism", en RORTY, A. O.; SCHMIDT,

J. (eds.): Kant's Idea for a Universal History with a Cosmopolitan Aim. A Critical Guide, Cambridge, Cambridge University Press, 2009.

KORSGAARD, C.: Creating the Kingdom of Ends, Cambridge, Cambridge University Press, 1996.

: "Introduction", en KANT, I.: Groundwork of the Metaphysics of Morals, Harvard, Cambridge University Press, 1997.

KUEHN, M.: "Reason as a species characteristic", en RORTY, A. O.; SCHMIDT, J. (eds.): Kant's Idea for a Universal History with a Cosmopolitan Aim. A Critical Guide, Cambridge, Cambridge University Press, 2009.

LINDSTEDT, D.: "Kant: Progress in Universal History as a Postulate of Practical Reason", Kant-Studien 90 (1999) 129-147.

MARIÑA, J.: "Making Sense of Kant's Highest Good”, Kant-Studien 91 (2000) 329-355.

O'NEILL, O.: Constructions of reason. Explorations of Kant's practical philosophy, Cambridge, Cambridge University Press, 1989. 
: "Kant on Reason and Religion, The Tanner Lectures on Human Values”, Harvard University, Cambridge, 1996.

https://tannerlectures.utah.edu/_documents/a-to-z/o/oneill97.pdf.

PATON, H. J.: The Categorical Imperative, Londres, Hutchinson, 1997.

REATH, A.: "Two conceptions of the highest good in Kant", Journal of the History of Philosophy 20, 4 (1998) 593-619.

RODRÍGUEZ ARAMAYO, R.: Immanuel Kant. La utopía moral como emancipación del azar, Buenos Aires, Edaf, 2001.

SMITH, S.: "Worthiness to be Happy and Kant's Concept of the Highest Good", Kant-Studien 75 (1984) 168-190.

STRATTON-LAKE, P.: "Formulating Categorical Imperatives", KantStudien 84 (1993) 317-340.

WATKINS, E.: Kant and the Metaphysics of Causality, Cambridge, Cambridge University Press, 2005.

WOOD, A.: Kant's moral religion, Nueva York, Cornell University Press, 1970.

: "Rational theology, moral faith, and religion", en GUYER, P. (ed.): The Cambridge Companion to Kant, Cambridge, Cambridge University Press, 1992.

: "Kant's Philosophy of History", en KLEINGELD, P. (ed.): Toward Perpetual Peace and other Writings on Politics, Peace and History, Nueva York, Yale University Press, 2006.

: Kantian Ethics, Cambridge, Cambridge University Press, 2008.

: "Kant's Fourth Proposition: the unsociable sociability of human nature", en RORTY, A. O.; SCHMIDT, J. (eds.): Kant's Idea for a Universal History with a Cosmopolitan Aim. A Critical Guide, Cambridge, Cambridge University Press, 2009.

YOVEL, Y.: Kant and the Philosophy of History, Princeton, Princeton University Press, 1980. 


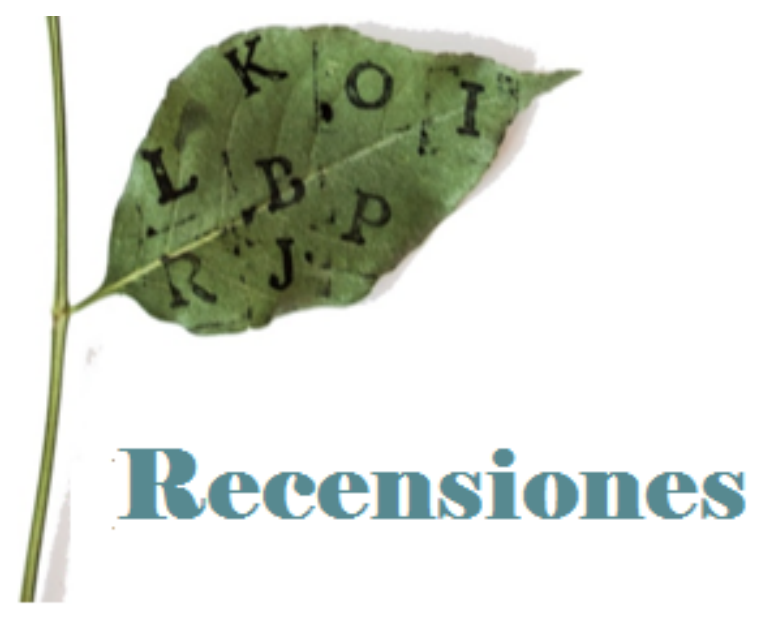




\title{
Mario Caimi: Kant's B Deduction. Newcastle upon Tyne, Cambridge Scholars Publishing, 2014, 140 pp. ISBN (13): 978-1-4438-6537-1
}

\author{
PAOLA RUMORE ${ }^{1}$
}

The volume by Mario Caimi-published in the series "Kantian Questions", edited by Pablo Muchnik - presents the English translation of his previous Leçons sur Kant. La déduction transcendentale dans la deuxième édition de la "Critique de la raison pure" (Paris, 2007), originated in a lecture he held at the Sorbonne in 2004.

According to its original didactical aim, the volume follows the structure of the Transcendental Deduction in the form it assumes in the second edition of the Critique of pure reason. The idea of providing a commentary on one of the most controversial parts of Kant's first Critique, instead of suggesting a new general interpretation of its role within the transcendental philosophy is the outcome of a clear methodological choice. Let's read what Kant wrote instead of interpreting, seems to be the very reasonable claim Caimi puts at the very basis of his enterprise. Nevertheless, his carefully textual approach provides malgré lui a very specific interpretation of Kant's text, suggesting a way of understanding the central problem of the transcendental philosophy-i.e. the relationship between representation and object - from a clearly new perspective. Thus, Caimi's methodological approach suggests facing the argument of the B-Deduction as $a$ whole, instead of looking at it as at a bunch of particular issues which have to be analyzed separately. This kind of investigation is driven by three statements that Caimi explicitly presents at the very beginning of his examination. First, the centrality of the Principle of Apperception, whose synthetic enrichment Caimi considers to be the line that runs through the development of Kant's argument. Second, the claim of a 'negative purpose' for the Deduction, whose task is to prove that the categories are not empty

\footnotetext{
${ }^{1}$ Università degli Studi di Torino. Contact: paola.rumore@unito.it.
} 
concepts at all; but the other way round it means: what would happen if the Deduction should fail, and categories turn out to be concepts without contents? Third, the importance of the "synthetic method" that Kant seems to follow in the general elaboration of his work (2014: XI).

According to the first of the mentioned issues, the main goal of Caimi's approach is to show that the entire argument of the Deduction consists in a "progressive enlargement and enrichment of the Principle of Apperception" (2014: XI). This is coherent with the idea that this seems actually to be the general pattern that Kant adopts in each part of the Critique. In fact, according to Caimi Kant's general idea of 'philosophical investigation'-from the early 1760 s up to the Critique-is perfectly consistent with the methodological concern of tradition of the German Enlightenment, in the sense that Kant himself seems to understand the task of philosophy as the increasing of the degree of distinction of concepts which are initially confused and whose origins are undetermined. Caimi summarizes this claim as follows:

In order to attain this distinction, the philosopher must first isolate the elements of the concept and study them separately. He must isolate a single element and bring it to distinction. This leads him to other elements which might have possibly been unknown to him but which are hereafter necessarily required for the complete analysis of the first element. [...] The new elements, so introduced, are in turn brought to distinction and joined to the first element. This procedure is repeated in a synthesis of increasing complexity, until the searcher is in a position to reconstruct the original concept, but now with entire clarity and distinction (2014: 12).

This is the way Kant follows in the first Critique, whose method of isolating elements is explicitly declared in the Transcendental Doctrine of Elements, which reveals the difficulty to explain the unity of consciousness by means of a mere passive sensibility, and compels Kant to introduce a new element, the active faculty of understanding, which is again analyzed in its components (in the Transcendental Logic), brought to distinction, and then synthesized with sensibility in a more complex synthesis in the chapter on the transcendental faculty of judgment. "The Critique [asserts Caimi] is built following this method of isolation and progressive synthesis" (2014: 13). 
In the case of the Deduction, the starting point is the very general and vague concept of 'combination in general', that is of a 'synthesis' related to a 'manifold'. The three chapters of Caimi's book follow the progressive unfolding and enrichment of this principle in the Deduction, focusing on the question of "Unity and the Object" (ch. 1, which analyses $\S 15-\S 20$ of Kant's text), of "The Application of the Categories" (ch. 2, which concerns §21-§25), and finally of "The Application of the Categories to Real Objects" (ch. 3 for $\S 26-\S 27)$.

Unfolding the initially indeterminate concept of combination Caimi isolates, following Kant, three elements which are necessary to conceive it, namely, a manifold, a synthetic action, and a rule. In fact, a synthesis requires a manifold to be synthesized, the thought of a unity, and an intellectual rule which allows us to bring to an end the otherwise endless repetition of the synthesis provided by the imagination, and which provides the unity of the representation (for instance, the unity of the representation of a specific number, which is obtained by means of the rule represented by the concept of that number that commend to stop adding units once that number is reached). It is precisely the thought of unity that works as the condition both of the manifold, and of its synthesis; a (qualitative) unity that Caimi explains in an extremely clear way following a rather obscure suggestion Kant makes in B 114 , where he compares it to "the unity of the theme in a play, a speech, or a story". Taking these examples in a rigorous and literal sense, Caimi states that the 'play' we should consider in reading Kant's text is that of (possible) experience, which must be 'one', only one, as well as the subject of such experience. Experience - the play of experience - has its own unity; despite its variety, it is necessarily the experience of one subject, of the one and only Self. This is the way that leads Kant to the introduction of the unity of apperception in $\S 16$, with the notorious claim "It must be possible for the 'I think' to accompany all my representations" (B131-132), a principle that represents the red thread that runs through the paragraphs of the Deduction, and whose unfolding and synthetic enrichment allows to rethink in a more perspicuous way the general structure and the whole argument of the text.

The process of determination of the originally vague concept of combination has lead to the concept of the Self, which implies the concepts of unity of consciousness, of the identity of the Self, and of Selfconsciousness (apperception). These concepts are all included in the so-called 
Supreme Principle of Understanding, i.e. to the principle that the manifold must be referred to the unity of apperception. The reciprocal implication of Self and manifold (the data of intuition) requires to enrich the concept of synthesis with the introduction of the concept of object. This is what is provided in $\S 17$ of the Deduction, where the object of knowledge is the new element that enlarges the principle of apperception, in the sense that at this point we are no longer dealing with the mere possession of representations, but with representations insofar they refer to something else, that is to the object. The conception of the object as a collection of predicates united by a concept that works as a rule of the synthesis establishes that objectivity is nothing but the necessity shown by certain synthesis, a necessity which is due to their being ruled by a concept. The unity provided by this rule is not merely analytic, but synthetic, because it is based on the necessary unity of apperception. In Caimi's words: "such a fundamental synthesis supplies the universally necessary rule of all synthesis of representations: the Principle of Apperception" (2014: 40). It allows the representation to pass from a mere subjective to a proper objective validity. Intuitive representations can become objects.

Proceeding along this line of unfolding and enriching the concepts he is dealing with, in $\S 18-\S 19$ Kant adds to the principle of (objective unity) of apperception the concept of judgment, which allows him a more precise formulation of the principle we have read in B131, that now sounds: "all the manifold of intuition (formerly 'all my representations') must be subject to (capable of being accompanied by) the logic-transcendental form of judgment (the objective unity of self-consciousness, the 'I think')" (2014: 56). Being the form of judgment the condition of the objectivity of the object itself, it refers to the object. Kant can, therefore, reach the goal of the Deduction (how do a priori concepts may refer to object?) by showing that this form is itself an a priori concept or that it contains a priori concepts. And that's what he accomplishes by mean of the introduction of the pure concepts of the understanding, the categories, now presented as the "functions of judgment, in so far as they are employed in determination of the manifold of a given intuition" ( $\$ 20, \mathrm{~B} 143)$. It means that determining the manifold of intuition with respect to the transcendental form of judgment is identical with determining the manifold of intuition according to the categories. Caimi's claim that the argumentative structure of the Deduction can be read as a progressive enlargement of the Principle of Apperception formulated in B131 
finds here its confirmation, since the statement that the manifold of intuition is necessarily subjected to the categories means nothing but that the subjection under categories is the condition for the manifold of intuition to be brought into one consciousness (see 2014: 59).

The further development of the Principle of Apperception allows Kant to introduce the distinction between thinking and knowing an object (\$22), and the related restriction of the validity of the categories to the sole knowledge of sensible empirical objects (\$23), to a material which is somehow 'alien' to the subject. If the deduction should fail to demonstrate that categories refer to empirical objects, one should admit that they are nothing but empty concepts. Caimi is progressively moving to the second step of his investigation (2014: ch. 2), where he follows Kant in showing that categories would be empty if they referred to a manifold which is barely thought (i.e. possible) and not actually given (i.e. real, sensible). The problem of the emptiness of a concept had already been at the center of an important work Caimi published in 2005- “Gedanken ohne Inhalt sind leer" (KantStudien, XCVI, 135-146) - , where he stressed the originality of the Kantian formula within the context of the Leibnizian and Wolffian understanding of representations. It is on the basis of the new understanding of empty concepts as concepts which have no corresponding intuition, that Caimi sees one of the main tasks of the Deduction in a negative purpose, namely in the necessity to show that categories are not empty $(2014: 11,74)$. Thus, in $\S 24-\S 26$, Kant considers the relation of the apperception to the 'alien' element contained in the empirical sensible manifold firstly through the investigation of the relation of the understanding to pure intuitions, then to the empirical manifold. Once again this consideration implies the introduction of new elements in the argumentation, i.e. the element of pure intuition of time and that of the function of imagination.

At this point of his reconstruction of Kant's argument, Caimi introduces a very insightful "Digression on imagination" (2014: 84-88) which deserves special attention since it presents Kant's account of this particular function in a somehow unusual way, which turns out to be very helpful in understanding its relation both to understanding, and sensibility. Caimi conceives imagination "as being nothing but understanding, insofar as understanding addresses itself to sensibility" (2014: 85). Imagination is namely understanding itself when the latter does not obey exclusively the 
laws of logic (the laws of identity and non-contradiction), but to the laws of sensibility too. In fact, when understanding operates within the sensible manifold of space or time, it does not follow barely the logical laws but also the laws of time that rule the transition from one representation to another. Only by means of those laws, two representations can be one 'before' the other, or 'successive', or 'simultaneous'. It means that imagination turns out to be something more than the faculty to represent an absent object, as in the philosophical tradition Kant belonged to. Furthermore, by saying that imagination is "the faculty of representing in intuition an object even if it is not itself present" (B151), Kant intends to stress that imagination performs its synthesis with no regard to the fact that the object is present or absent. Imagination is not limited to a reproductive function; it performs an apprehension, that is a kind of synthesis, and is, therefore, a spontaneous function. More precisely: a function of the understanding whose specific feature lies in its being referred to sensibility.

The "application of the categories to real object" is the topic of the last chapter of Caimi's book, entirely focused on the analysis of the final paragraphs of the Deduction $(\S 26-\S 27)$. It is in $\S 26$ that Kant comes to the demonstration that categories cannot be empty concepts since they are applied to actually existing objects. It means that in this paragraph Kant manages to overcome the gap between the empirical manifold and pure thought, proving the validity of the categories not only in relation to the pure form of sensibility but also in relation to the empirical contents of intuition (the object). In order to make clear which are the steps followed by Kant in achieving this result, Caimi formulates the problem of the Deduction (how is it possible for the categories to relate to empirical objects?) conversely (in conformity with B160): "how can empirical objects possibly be subject to those laws of synthesis which are thought in the a priori concepts?" (2014: 102-103). The path Kant follows goes from proving that every empirical representation is subject to the synthesis of apperception (B160-163) to the demonstration that all phenomena must be subject to the laws of understanding (B163-165). Distancing himself from De Vleeschauwer's groundbreaking interpretation according to which the three syntheses of the A-Deduction (apprehension, reproduction, recognition) are all included in the unique synthesis of apprehension of the B-Deduction (\$26), Caimi argues that Kant text should be taken literally since it is the sole synthesis of apprehension the one that has to synthesize the empirical manifold, 
incorporating it into the unity of apperception (2014: 103). And it occurs by means of the accordance between the synthesis of apprehension and the $a$ priori condition that consists in the synthetic unity of the intuitive manifold of space and time (the figurative synthesis provided by the imagination, according to which there are only one space and only one time), which in turn is achieved by means of synthesis ruled by the categories. Thus, the synthesis of apprehension is itself subject to the categories, as Kant states in B161. Caimi proves the reliability of his reading recalling in an accurate examination the two famous examples Kant introduces in B162-163, namely the example of the house and the one of the water (2014: 107-113). In both cases it is now clear that presupposing the empirical multiplicity the figurative synthesis of imagination, it is subject to the categories. Therefore categories are necessarily related not only to a possible object of the sensible intuition but also to actual objects of empirical sensible intuition. It means that categories are not empty concepts at all. Quod erat demonstrandum.

This cursory look into Caimi's useful book should have made clear at least the strategy he follows in his approach to the Kantian text. By means of an extremely accurate reading that takes into account both the letter and the goal of the Deduction as the two means that should provide reciprocal support in the reconstruction of Kant's argument, Caimi offers an essential contribution to the clarification of this controversial passage of the first Critique. The choice to expand the structure of the argument considered as a whole, instead of clarifying its particular components allows him to show the coherence and the intrinsic unity of the B-Deduction. In the end, the idea of explaining the argument by expanding its structure turns out to be a very successful approach not at least because Caimi follows his very valuable insight according to which "the entire Deduction obeys a single principle, namely the Principle of Apperception" (2014: 123). This principle undergoes an increasing enrichment and determination that allows moving from the concept of the Self as one, identical and self-conscious to the concept of the object, initially conceived as a form of synthesis and then as an actual object. The further enlargement of the principle by means of the notion of knowledge and imagination leads to the demonstration that categories are not empty concepts at all and that they do apply to actual empirical objects. Caimi's remarkable insight of bringing the Principle of Apperception at the very core in the argumentation Kant's fundamental problem in the Critique offers in fact not only a new, more coherent way of reading the obscure pages of the 
Deduction - a goal that deserves by itself huge credit. Besides that, it provides at the same time an efficient counteragent for any longstanding attempt of a psychological misunderstanding of the transcendental philosophy, now deprived of any possible argumentative and textual support. 


\title{
Gustavo Leyva, Álvaro Peláez y Pedro Stepanenko (Eds.): \\ Los rostros de la razón: Immanuel Kant desde Hispanoamérica (3 volúmenes). México, UAM-Cuajimalpa/Anthropos, 2018, 727 pp. ISBN (UAM): 978-607-28-1348-9/ISBN (Anthropos): 978-84-16421-91-6
}

\author{
FRANCISCO JAVIER IRACHETA FERNÁNDEZ ${ }^{1}$
}

Los rostros de la razón: Immanuel Kant desde Hispanoamérica, es un ambicioso primer trabajo colaborativo en tres volúmenes que se publica en lengua española sobre el conjunto de la filosofía crítica de Kant. En la obra participan un total de 34 autores especialistas en uno o varios de los 'rostros de la razón' de la filosofía crítica kantiana. El trabajo integra reflexiones y análisis en torno a los tres épicos momentos del pensamiento crítico kantiano y las avenidas que se desarrollan sobre la filosofía del derecho, la política, la naturaleza, la historia, la religión, la antropología y la geografía desde la filosofía trascendental, tal como esta se construye y articula en las tres grandes Críticas: la Crítica de la razón pura (KrV), la Crítica de la razón práctica $(K p V)$ y la Critica de la facultad de juzgar $(K U)$. Los tres volúmenes, como explican sus editores en la "Presentación general de la obra", tienen la intención de incorporar, siguiendo a Norbert Hinske, las tres 'dimensiones' del monumental trabajo del gran filósofo prusiano, a saber, la 'filología kantiana', que se ocupa de establecer y fijar los textos originales de Kant; la 'investigación kantiana', que se encarga de inquirir sobre cuestiones relacionadas con "la biografía, el desarrollo intelectual, el comentario a los textos, la historia de las fuentes y conceptos" del pensamiento del filósofo; $y$, finalmente, el 'kantianismo', que se entiende en torno a la 'sistematización' de las preguntas teóricas y prácticas que en conjunto comprenden la filosofía de Kant. En este sentido es que me refiero a Los rostros de la razón como un trabajo ambicioso y definitivamente bien estructurado que evidencia la calidad investigadora de cada una de las aportaciones reunidas en los tres

\footnotetext{
${ }^{1}$ Tecnológico de Monterrey. Escuela de Humanidades y Educación. Contacto: firacheta@tec.mx.
} 
volúmenes y que, en conjunto, demuestran la presencia de una ya autoritativa tradición kantiana latente en muchas universidades y centros de investigación en el mundo de habla hispana.

El primer volumen de la obra, dedicado a la teoría y que lleva como subtítulo "Filosofía Teórica", abarca estudios que se concentran, sobre todo, en los temas más relevantes de la $\mathrm{KrV}(1781 / 1787)$ — tanto de la "Estética", la “Analítica” y la "Dialéctica” trascendentales — y los Prolegómenos (1783). El segundo, destinado al tratamiento de la filosofía práctica y subtitulado "Filosofía moral, política y del derecho", incluye, en su primera parte, trabajos sobre la ética de Kant enfocados en temas esenciales que aparecen originalmente en la Fundamentación de la metafísica de las costumbres (GMS) (1785), la segunda Crítica (1788) y la "Doctrina de la virtud", dentro de la Metafísica de las costumbres (1797). A su vez, la segunda parte de este volumen está dedicada a la filosofía política y del derecho, e incluye contribuciones en torno a la "Doctrina del Derecho" y su aplicación al derecho penal y al bioderecho, los derechos humanos y el cosmopolitismo. Finalmente, el tercer volumen está orientado al estudio de la tercera Crítica (1790), la filosofía de la religión, la historia y la antropología kantianas, y lleva como título "Filosofía de la Religión, de la Historia y Crítica de la Facultad de Juzgar: Estética y Teleología”. Este último volumen incluye, por ende, ensayos sobre temas e ideas nucleares en torno a La religión dentro de los límites de la mera razón (1793), la filosofía de la historia, la Crítica de la facultad de juzgar y las diversas reflexiones, escritos y apuntes de clase dictados por Kant sobre la antropología. A continuación, se resume esquemáticamente el contenido de cada uno de los tres volúmenes, para terminar posteriormente con un breve comentario crítico de la obra en su conjunto.

\section{Volumen I. Filosofía Teórica}

El volumen I de la obra, "Filosofía Teórica", comprende ensayos que van desde el significado del idealismo trascendental y la Revolución Copernicana que este idealismo inaugura en la reflexión epistemológica y metafísica hasta el influjo del idealismo trascendental en el postidealismo kantiano schellingeano. A mi modo de ver, podemos dividir los temas y objetivos de los ensayos aquí reunidos en cuatro áreas o avenidas diferentes. 
El primer grupo (i), conformado por los ensayos de Mario Caimi, investigador del Consejo Nacional de Investigaciones Científicas de la Universidad de Buenos Aires, "La Revolución copernicana del modo de pensar: Algunos problemas", y de Jacinto Rivera de Rosales, de la Universidad Nacional de Educación a Distancia, "El nuevo realismo y el 'Goodbye' a Kant de Maurizio Ferraris", se enfoca en explicar la base de la filosofía de Kant a partir del concepto de Revolución Copernicana, el cual se fragua en el 'ensayo' de suponer que el objeto de conocimiento está determinado por las condiciones cognitivas a priori de la mente. Situados ambos ensayos en el contexto de una relevante discusión contemporánea, muestran que el núcleo de la revolución filosófica kantiana lo constituye un 'Yo trascendental' — no un yo antropológico - cuyas categorías e intuiciones puras de la mente determinan la representación empírica de cualquier objeto de conocimiento posible. Kant propone este 'ensayo' para eliminar el grave problema que encara el 'realismo ingenuo', sustentado en el realismo trascendental, de no poder salir de las ideas propias de la mente al intentar explicar el mundo externo, conduciendo así, inevitablemente, al escepticismo.

El segundo grupo (ii) está conformado por los ensayos de Pedro Stepanenko, investigador del Instituto de Investigaciones Filosóficas de la UNAM, "Todos los contenidos de la experiencia son conceptuales en la filosofía de Kant"; Julia Muñoz, de la UNAM, "La posibilidad del error epistémico en la caracterización kantiana de las categorías", y Stéfano Straulino Torre, profesor del Instituto Tecnológico Autónomo de México, "Juicios subjetivos y juicios sobre sujetos: una distinción a propósito de los juicios de percepción”. El común denominador de estos tres textos se halla en la reflexión en torno a aquello que resulta esencial para determinar el valor de verdad de los juicios, esto es, tanto su posibilidad de verdad como de error. Se trata de una importante cuestión dentro de la teoría del conocimiento kantiano, la cual no ha dejado de generar discusión desde la aparición misma de la primera edición de la $K r V$. En efecto, una de las principales objeciones que recibió Kant, poco menos de un año después de haber publicado su obra, en la reseña de Göttingen escrita por Feder y Garve, versó justamente sobre la ambigüedad con la que trataba, en la "Deducción trascendental de las categorías", a los conceptos del entendimiento, pues o bien podían comprenderse como condiciones necesarias de posibilidad de cualquier juicio con sentido (presentes incluso en los sueños), o bien como condiciones 
suficientes de cualquier juicio verdadero (ausentes necesariamente en los sueños). Claramente, la cuestión estriba en que ambas condiciones no pueden ser concluyentes al mismo tiempo. Kant intentó atacar esta ambigüedad al introducir, en sus Prolegómenos, la diferencia entre los juicios de percepción y los juicios de experiencia; y la virtud de los tres ensayos que abordan esta temática, dentro de este primer volumen, estriba justamente en situar la discusión en un horizonte contemporáneo sin perder a la vez sensibilidad a consideraciones antropológicas, filológicas y filosóficas.

A su vez, el tercer grupo (iii) está conformado por los ensayos de Álvaro Peláez Cedrés, de la Universidad Autónoma Metropolitana, "Espacio trascendental, lugar particular y espacio geográfico. Sobre la teoría del espacio de Kant" y Pedro A. Viñuela Villa, de la Universidad Internacional de la Rioja, "Construcción aritmética de conceptos". Ambos ensayos tienen como hilo conductor mostrar el lugar de primerísimo orden que tiene la intuición del espacio en Kant, tanto en su forma completamente pura como en su aplicación antropológica. En su forma pura, como lo muestra el segundo de estos trabajos, el espacio dentro de la filosofía kantiana resulta indispensable para la propuesta de una filosofía elemental de las matemáticas, en cuanto que gracias a esta intuición pura es posible construir, con ayuda de los conceptos, cualquier operación aritmética (al modo como funciona un ábaco). Asimismo, en cuanto a su aplicabilidad mundana, si se nos permite llamarlo así, se trata de una intuición trascendental que resulta ser condición de posibilidad misma del espacio empírico. El tratamiento del espacio empírico y geográfico que se da en el primero de estos dos trabajos resulta bastante novedoso dentro de los estudios kantianos. No solo porque muestra el modo en que la concepción de cualquier escenario geográfico del mundo no es para nada incompatibilista con la filosofía trascendental del filósofo, algo contrario a lo que bastantes comentaristas, contemporáneos y no tanto, han sostenido, también porque introduce en la discusión textos pre-críticos del filósofo que intentan ser articulados con la concepción crítica a priori sobre el espacio.

Finalmente, el cuarto grupo (iv) de ensayos de este primer volumen está compuesto por los trabajos de Manuel Sánchez Rodriguez, de la Universidad de Granada, "La crítica y la transformación de Leibniz en los Progresos y en la respuesta de Kant a Eberhard", Pablo Oyarzún Robles, de la Universidad de Chile, "Pensamiento, lenguaje y 'yo'. Lichtenberg y Kant" 
y de Marcela García, profesora-investigadora del Instituto de Investigaciones Filosóficas de la UNAM y de la Universidad Michoacana de San Nicolás de Hidalgo, "Nunca se han apiñado tantos pensamientos profundos en tan pocas hojas...'. La intuición intelectual en Schelling”. El denominador común de estos ensayos es poner de relieve la recepción de algunas ideas clave de la filosofía teórica de Kant, tal como aparecen por vez primera en la $\mathrm{KrV}$, y el diálogo crítico que puede suscitarse a partir de estas recepciones reflexivas por parte de algunos de los más importantes críticos y filósofos - o al menos asiduos lectores y comentaristas - contemporáneos al propio filósofo, como Eberhard, Lichtenberg y el propio Schelling.

\section{Volumen II. Filosofía moral, política y del derecho}

El segundo volumen de la obra cubre temas esenciales de la filosofía práctica de Kant. El tomo consta de seis ensayos sobre ética y siete más sobre filosofía política y del derecho. Siguiendo esta estructura, el volumen se divide en dos partes: "Filosofía moral" y "Filosofía política y del derecho". En la primera parte encontramos una conducción en el orden de las contribuciones que van de la libertad ontológica hacia un sistema concreto de deberes con orientación antropológica, aunque podemos hallar entre ellos una interesante controversia en torno a la libertad ontológica kantiana. Los ensayos que defienden la libertad trascendental kantiana comparten una preocupación por desmentir la idea generalizada de que la ética de Kant es poco atractiva por ser, sin más, puramente formalista; mientras que los dos ensayos que cuestionan la realidad práctica de este concepto de libertad lo hacen precisamente por razones que tienen que ver, según sus autores, con sus consecuencias de inaplicabilidad antropológica.

El primer ensayo, de Sebastián Cabezas, de la Universidad de Chile, "Concepción de la moralidad en el 'Canon' de la $K r V$ a la luz de la GMS', analiza el cambio fundamental que hace Kant en su teoría ética entre el 'Canon' de la Crítica de la razón pura y la Fundamentación de la metafísica de las costumbres; un cambio 'revolucionario' por cuanto que va de la heteronomía moral a la autonomía moral de la voluntad. El segundo ensayo, de Fernando Moledo, de la Universidad de Buenos Aires, "La deducción del imperativo categórico en la Fundamentación: una propuesta de reconstrucción”, muestra de manera concisa y bien argumentada el arduo camino de 'la deducción' que Kant hace en la tercera parte de GMS, justo lo 
que Kant requiere para salir de ese atolladero motivacional externo que encontramos en la "Dialéctica Trascendental" y el "Canon" de la $\mathrm{KrV}$, tal como se trató en el ensayo previo. Le sigue el ensayo de Luis Eduardo Hoyos, de la Universidad Nacional de Colombia, "Kant y la motivación racional". El autor aporta una perspectiva crítica de la 'deducción' de la moralidad tal como Kant intentó hacer en la tercera parte de la Fundamentacion. El texto de Hoyos pone en cuestión la realidad práctica de la libertad trascendental y, con ello, la motivación del deber por el deber, y aboga por una comprensión exclusivamente racional de la motivación moral. El cuarto ensayo, de Leonardo Tovar González, de la Universidad de Santo Tomás, "Decisión y ejecución en la ética Kantiana”, retoma el tema de la motivación en el asunto de la ejecución, la incidencia efectiva del acto en la ética de Kant. El autor defiende el punto de que no existe una ruptura entre el formalismo deóntico presente en la Fundamentación y en la segunda Crítica y la "Doctrina de la virtud", y lo hace echando mano de aquello que el texto anterior ponía fuertemente en cuestión, a saber, la libertad de la voluntad en sentido ontológico fuerte, esto es, trascendental. Es decir, el autor argumenta que hay un paso consistente del formalismo a la ética antropológica y que radica en aplicar la libertad trascendental a los deberes de virtud.

En el ensayo siguiente, "Algunas observaciones comparativas entre la división de los deberes éticos en la Metaphysik der Sitten de Kant y la Sittenlehre de Fichte", Vicente de Haro Romo, de la Universidad Panamericana, reflexiona en torno a las similitudes y diferencias que tienen entre sí los sistemas filosóficos de las costumbres de Kant y Fichte. Las similitudes están en torno a la existencia de dos clases de deberes hacia uno mismo y hacia los demás (perfectos/imperfectos, para el caso de Kant, y condicionados/incondicionados, para el de Fichte), mientras que las discrepancias se hallan en torno a ciertos contenidos específicos. Al igual que el autor precedente, de Haro sostiene que, para el caso de Kant, la "Doctrina de la Virtud" es consistente con la libertad trascendental y explica que en esta parte de la Metafísica de las Costumbres podemos encontrar un punto de comunión entre el filósofo de Königsberg y Aristóteles. El último ensayo de la parte concerniente a la filosofía moral, “EÉtica pura o ética impura? Kant, el racismo y la ceguera del color”, de Luis Moisés López Flores, profesor del Tecnológico de Monterrey, toca precisamente el tema con el que Kant busca culminar su proyecto ético, a saber, la 'antropología práctica'. Haciendo uso de importante material histórico-bibliográfico del periodo pre-crítico de Kant 
sobre geografía y razas, el autor señala que la ética pura de Kant peligrosamente puede redundar en problemas morales raciales y, por ello, aboga más en favor de una ética impura que, a mi modo de ver, favorece la problematización en torno a la libertad ontologizada dentro de la ética de Kant.

La segunda parte del segundo volumen toma como punto de partida precisamente la Metafísica de las costumbres. El ensayo de Enzo Solari, de la Pontificia Universidad Católica de Chile, titulado "El carácter moral del derecho según Kant", reflexiona en torno a la relación kantiana de la moralidad con el derecho. El autor argumenta en favor de una necesaria vinculación, pues el derecho se funda precisamente "en la facticidad de la moral". En este sentido, las normas jurídicas tienen su validez objetiva en los principios universales que emanan de la libertad de los agentes. Le sigue el ensayo de María Guadalupe Martínez Fisher, del Centro de Investigación Social Avanzada de la UAM-Iztapalapa, titulado "Reflexiones en torno a la doctrina kantiana del derecho natural". La autora explora el sentido en el que la doctrina del derecho de Kant es iusnaturalista, considerando que el fundamento del derecho parte de lo que, en efecto, podemos llamar la 'naturaleza metafísica' del agente como homo noumenon, esto es, como trascendentalmente libre. El siguiente ensayo, "La doble naturaleza del derecho en Kant", de Óscar Cubo Ugarte, de la Universidad de Valencia, se enmarca dentro del mismo contexto al querer mostrar que la clave de la normatividad jurídica en Kant no se halla sino en la naturaleza de la persona como ser racional (puro). El texto explica la articulación que existe entre el derecho como fundamento racional (derecho natural) y el derecho como expresión positiva (derecho positivo). El cuarto ensayo de esta segunda parte del volumen, "El derecho innato es solo uno. ¿Tiene Kant una filosofía de los derechos humanos?", de Otfried Höffe, de la Universidad de Tubinga —el único autor no hispanoamericano de la selección - incursiona en la distinción que hay entre el derecho innato que subraya Kant en la Metafisica de las Costumbres y los derechos humanos como derechos circunscritos al derecho de gentes que Kant trata en Teoría y práctica. Lo que intenta hacer Höffe es mostrar que la idea de Kant de un solo derecho innato establece un criterio para los derechos humanos, pero se trata, propiamente hablando, de un derecho jurídico y no ético. El ensayo que le sigue, "Kant y el derecho cosmopolita", de Gustavo Leyva, de la UAM-Iztapalapa, reflexiona en torno a la cuestión del orden y el derecho cosmopolita en la obra de Kant. Situando 
la cuestión cosmopolita que inquietaba a Kant en su contexto histórico, sobre todo en relación con la firma del Tratado de Basilea entre Francia y Prusia en 1795, el autor plantea que la filosofía del derecho cosmopolita en Kant representa hoy en día un problema porque su reducción al derecho de hospitalidad se queda corto para afrontar algunos conflictos políticos globales contemporáneos, como las migraciones y éxodos masivos de personas de un país a otro motivados por razones económicas, políticas o religiosas en contextos bélicos. Así, no puede reconocerse su fuerza si no se amplía o complementa con otros derechos. Finalmente, los últimos dos textos del volumen, "El derecho penal en Kant: los límites del retributivismo", de Francisco Cortés Rodas, de la Universidad de Antioquia, Colombia, y "El problema de los bioderechos a la luz del pensamiento de Immanuel Kant”, de María Jesús Vázquez Lobeiras, de la Universidad de Santiago de Compostela, reflexionan en torno a la posible aplicabilidad de la filosofía del derecho de Kant. El primero lo hace sobre la instancia político-social del proceso de negociación entre el gobierno colombiano y la guerrilla de las FARC, en Colombia, mientras que el segundo lo hace en torno a problemas de la bioética y los bioderechos. En este sentido, constituyen dos excelentes contribuciones al aplicar la discusión teórica jurídica de Kant a problemas políticos y biopolíticos contemporáneos.

Volumen III: Filosofía de la Religión, de la Historia y Crítica de la Facultad de Juzgar: Estética y Teleología

El último volumen de la obra cubre artículos relacionados con la filosofía de la religión, la historia, y la tercera Crítica, esto es, la naturaleza del juicio estético y teleológico. En conformidad con esta triple temática, el volumen se divide en tres partes. La primera parte la constituye la "Filosofía de la religión", compuesta por un total de cuatro ensayos; la segunda parte es la "Filosofía de la historia", con dos ensayos; y la tercera es la "Crítica de la facultad de juzgar: estética y teleología”, que reúne un total de cinco ensayos.

La primera sección abre con el artículo de Pedro Jesús Teruel, de la Universidad de Valencia, titulado "El sujeto voluble: significado, sentido y modulación neurofilosófica de la fragilitas kantiana”. El autor se centra en la primera parte de La Religión dentro de los límites de la mera razón para examinar la doctrina de Kant sobre la fragilitas, esto es, la propensión humana al mal moral desde la propia debilidad de su voluntad: actuar por una 
máxima mala a sabiendas de que lo es. Se trata del problema de la famosa akrasia descubierta por Aristóteles, pero contextualizado, desde luego, en la versión moral de Kant. La intención del autor es atender a este inexplicable fenómeno racional, que Kant trata en el marco de la conducción de la moral hacia la religión, acudiendo a un enfoque neurocientífico y biológico evolutivo. Le sigue el ensayo de Leonardo Rodríguez Duplá, de la Universidad Complutense de Madrid, que lleva como título "La eclesiología racional kantiana". El autor se centra en la última parte del escrito de la religión de Kant, en donde el filósofo avanza la tesis de que los seres humanos tienen la peculiaridad de corromperse los unos a los otros en sus interacciones sociales, lo que le lleva de la mano a sostener que el peor enemigo moral del hombre es la propia humanidad. El autor intenta mostrar la consistencia de esta afirmación basada en la antropología, particularmente en el uso que hace el hombre de su razón al compararse a sí mismo con los demás, y explica el importante papel que tiene el concepto de 'Iglesia invisible', dentro del texto de La Religión, como concepto que puede dar fe, a pesar de esta tendencia racional al mal, del progreso moral del ser humano. El tercer ensayo de la "Filosofía de la religión", "Gesinnung y autoconocimiento en la filosofía de la religión kantiana", de Eduardo Charpenel Elorduy, de la Universidad Panamericana, aborda la relación que existe entre el concepto de Gessiniung kantiano y las máximas como principios subjetivos de acción, tal como estas aparecen explicadas en la Fundamentación y la segunda Critica. El autor propone la traducción de la Gessinung en castellano como 'disposición fundamental' y muestra que, dentro del contexto de la Religionschrift, se trata del principio subjetivo fundamental que debe regular cualquier otra máxima. En este sentido, la Gessinung es la fuente dadora de máximas o la fuente misma de la elección que, por su propia naturaleza inteligible, es atemporal e innata. A mi modo de ver, se trata de una aportación importante en el seno de la distinción explícita — que no aparece hasta la Religionschrift- que Kant hace entre Wille y Willkür, pues siendo que la libertad está en Willkür, Wille viene a ser representado como la fuerza innata, caracterizada precisamente por la Gessinung, de donde emana tanto el principio bueno como el malo. Finalmente, el artículo de Dulce María Granja Castro, de la Universidad Autónoma Metropolitana (Iztapalapa), titulado "La presencia del Nuevo Testamento en la Religión dentro de los límites de la mera razón", cierra la primera parte de este volumen. La autora se aparta de una interpretación tradicional del texto kantiano de la Religión según la cual la filosofía de la 
religión de Kant no es sino una añadidura de pensamientos incoherentes de su filosofía moral. En pleno contraste con esta interpretación, la autora defiende la tesis de que, si bien es cierto que existe dentro del texto de $L a$ Religión una importante cantidad de referencias al Nuevo Testamento, también lo es que la filosofía de la religión conforma una parte fundamental de la filosofía crítica en su conjunto; lo que no quiere decir que en la Religionschrift Kant tiene la intención de, o bien sustraer la religión a su sistema de pensamiento ético, o bien remplazar el cristianismo por una religión racional.

La segunda parte de este volumen, dedicado a la "Filosofía de la historia", abre con el ensayo de Ileana Paola Beade, investigadora del Consejo Nacional de Investigaciones Científicas y Técnicas de la Universidad Nacional de Rosario, Argentina, titulado "Reflexiones en torno al concepto kantiano de una historia a priori". Partiendo del texto kantiano de filosofía de la historia de 1784, Idea para una historia universal en clave cosmopolita, la autora reflexiona en torno al "carácter normativo de la historia a priori" kantiana, usando como hilo conductor la relación que existe entre teoría y práctica tal como Kant establece el significado de estos conceptos en su trabajo de Teoría y Práctica de 1793. El ensayo es un análisis sobre la aplicación a priori de la teoría práctica a la historia, obligándola a responder de modo normativo a lo que se le pide y a obtener así 'signos' de progreso moral. En esta misma línea de historia filosófica le sigue el ensayo "Kant, el progreso moral y la responsabilidad hacia la historia", de Wilson Herrera Romero, de la Universidad de Rosario. Enmarcando su reflexión en el contexto de una discusión sobre "la conciencia histórica y el sentido de la historia" que encontramos en importantes pensadores contemporáneos como Koselleck y Ricoeur, el autor tiene la intención de mostrar que la filosofía de la historia kantiana no solo está al servicio de los intereses morales de la razón práctica, sino que también cada ser humano, en su capacidad de agente moral, tiene una responsabilidad histórica de hacer prevalecer el progreso moral de la humanidad. Una importante aportación del autor estriba en mostrar el sentido de esta responsabilidad en relación con la incorporación en el presente de las luchas del pasado y los esfuerzos prácticos con miras al futuro.

El último apartado del volumen, la "Critica de la facultad de juzgar: estética y teleología", comienza con el ensayo de Sandra V. Palermo, investigadora del Consejo Nacional de Investigaciones Científicas y Técnicas 
de la Universidad Nacional de Río Cuarto, "Substancia o mecanismo. Spinoza en la Kritik der Urteilskraft". La autora defiende, contrario a lo que comúnmente se mantiene, el punto de que Spinoza tiene una importante presencia en la filosofía de Kant, particularmente en la problemática sobre la 'totalidad' en la tercera de las Críticas. De acuerdo con ella, Kant tiene una lectura de Spinoza presente en la "Dialéctica de la facultad teleológica de juzgar", en la segunda parte de la Crítica de la facultad de juzgar, que sigue dos diferentes perspectivas, a saber, una ontológica y otra cosmológica. Su objetivo es mostrar la pertinencia de estas dos lecturas. Este ensayo se inserta en el contexto de una investigación más amplia sobre un modelo de razón compartido de ambos filósofos. Le sigue el ensayo de Silvia del Luján Di Sanza, del Centro de Investigaciones Filosóficas de la Universidad Nacional de San Martín, titulado "Kant ¿una estética negativa? Reflexiones sobre la función de la negación en el primer y segundo momento de la Analítica de lo bello en la Crítica de la facultad de juzgar estética de I. Kant”. Como lo indica el título, la autora reflexiona en torno a una estética negativa en la facultad del juicio estético kantiano recurriendo a dos momentos del juicio reflexionante estético, a saber, el carácter negativo del juicio 'sin interés' y posteriormente el carácter negativo del juicio 'sin concepto'. De acuerdo con su análisis, estos dos momentos negativos conducen al concepto positivo del libre juego de las facultades. A continuación, encontramos el ensayo titulado "La teleología moral de lo sublime", de Roger Pérez, de la Pontificia Universidad Católica del Perú. El autor busca mostrar la relación que tiene el sentimiento de lo sublime, tal como aparece en la tercera de las Críticas, con la posición 'éticoteológica' kantiana, esto es, la manera en que dicho sentimiento se manifiesta en consideración con un orden distinto al mecanismo natural y que, por pertenecer a la teleología, se presenta justamente en un orden moral. Si bien es cierto que la religión moral y el sentimiento de lo sublime mantienen entre sí una relación que no puede ser considerada 'absoluta', el autor sostiene que el sentimiento de lo sublime funge como una previa preparación reverencial del deber que no cumple como tal un criterio de fundamento motivacional, pero sí es importante para el descubrimiento de los deberes morales. El ensayo de Paula Órdenes, de la Universidad de Heidelberg, "Síntesis en los juicios estéticos de lo sublime", sigue la misma temática en torno a lo sublime, pero ahora en plena relación con el juicio estético como juicio reflexionante. La autora tiene intención de echar luz sobre la comprensión del modo en que opera el concepto de 
'síntesis' en el interior de los juicios sobre lo sublime como juicios ciertamente estéticos, centrando su análisis, específicamente, en las dos formas posibles de síntesis que operan desde la propia actividad mental del sujeto de acuerdo con Kant, esto es, la síntesis homogénea y la heterogénea. Se trata de una distinción que se remonta a la primera Crítica, de acuerdo con la cual Kant sustenta los juicios matemáticos y dinámicos, respectivamente. El volumen cierra con la contribución de Luciana Martínez, investigadora del Consejo Nacional de Investigaciones Científicas y Técnicas de la Universidad de Buenos Aires. En su texto, "El concepto de genio en las lecciones de Antropología de la década silenciosa de Kant", la autora analiza el significado de genio en conformidad con el tratamiento que le da Kant en sus lecciones de Antropología comprendidas entre los años 1770-1780, esto es, la llamada 'década del silencio' del filósofo de Königsberg. El ensayo es muy pertinente dentro de la temática del desarrollo de pensamiento de Kant en tanto que muestra la manera como se gesta el concepto de genio en un periodo de 20 años y que tiene su momento más acabado en la tercera Crítica.

Como ya lo he comentado al inicio, los tres volúmenes cubren la totalidad de los temas más significativos del pensamiento crítico de Kant. A excepción de un par de ensayos del segundo y el tercer volumen, que dan cuenta de manera importante tanto del periodo pre-crítico como de la 'década del silencio', que representa un parteaguas en el desarrollo del pensamiento del filósofo, el resto de los trabajos contenidos en estos tres volúmenes están esencialmente enfocados en las obras más prominentes de la filosofía crítica, esto es, lo que Kant escribe y publica a partir de 1781. En cuanto a la calidad de los textos presentados, así como en lo que respecta a la cuestión de los temas que se discuten, la obra Los rostros de la razón: Immanuel Kant desde Hispanoamérica se convierte desde ya en un referente indiscutible de la filosofía crítica kantiana en lengua española.

Con todo, la obra no incluye estudios enfocados en otros trabajos también importantes de la filosofía pre-crítica de Kant por abundar en consideraciones antropológicas; trabajos que tienen una gran riqueza popular, sobre todo moral, y que revelan la personalidad del 'galante Magister' que era Kant en la década de los 60. Por ejemplo, no hay ensayo alguno dentro de los tres volúmenes que comente o analice temáticas tratadas en textos tales como Los sueños de un visionario o las Observaciones sobre 
el sentimiento de lo bello y lo sublime y que resultan fundamentales si queremos comprender tanto la evolución como la continuidad del pensamiento del filósofo. Es cierto que encontramos en Los rostros de la razón ensayos que no dejan sin discutir temas críticos aterrizados a la antropología y geografía. Pero se trata de trabajos que sobre todo efecúan una interpretación trascendental de la antropología. Falta por terminar de atar, en mi opinión, la antropología y geografía con los escritos pre-criticos de los años populares y sociales del Magister Kant, esto es, llevar a cabo una investigación popular precritica de la antropología. A juzgar por el hecho de que Kant nunca dejó de escribir y enseñar sobre antropología, es razonable sostener que la investigación de su antropología filosófica es clave para entender el desarrollo y la identidad de su pensamiento; pero puesto que hablamos de un Kant pre-crítico y otro crítico, no está clara la continuidad de una una antropología filosófica crítica de otra antropología filosófica precrítica. Es fundamental trabajar una y otra si queremos entender cabalmente las diferentes caras del pensamiento de Kant. 


\title{
Ileana Beade: La libertad y el orden en la filosofía jurídica kantiana. Rosario, Fhumyar Ediciones, 2017, 310 pp. ISBN: 978-987-3638-16-9
}

\author{
MARILÍN GÓMEZ
}

La libertad y el orden en la filosofía jurídica kantiana es una síntesis de la tesis de Doctorado en Ciencias Políticas de la Dra. en Humanidades y Artes con mención en Filosofía Ileana Beade (Universidad Nacional de Rosario, Argentina). Publicado por la editorial de la Facultad de Humanidades y Artes de la UNR, se trata de un nuevo estudio sobre un problema fundamental de la filosofía política moderna: la preservación de la libertad en el estado civil, en tanto su constitución implica necesariamente la sujeción a las leyes. Con claridad, y con amplios fundamentos tanto en la obra kantiana como en las discusiones que han proliferado a partir de ella, Beade analiza esta articulación entre libertad y sujeción a la ley en la filosofía político-jurídica de Kant. A la luz de su conexión con los principios fundamentales de la filosofía kantiana de la historia, las dificultades se allanan.

El eje de dicha investigación es esclarecer la tensión entre la concepción de la libertad político-jurídica y una serie de aspectos doctrinales que la autora caracteriza bajo la expresión imperativo del orden. Respecto al primer término de esta relación, la libertad jurídica es definida por Kant como la capacidad de un individuo de obedecer solo aquellas leyes a las que ha dado su consentimiento (véanse $M S$, Ak. VI, 314; ZeF, Ak. VIII, 350). Fundada en el principio de auto-legislación, la libertad aparece como un derecho innato e inalienable del hombre, que debería ser preservado en el estado civil. El segundo término en esta tensión es formulado por la autora como imperativo del orden, y abarca tres nociones que generan dificultades frente a la ya enunciada definición de libertad jurídica, a saber: la exigencia de una obediencia estricta en el ámbito del uso privado de la razón, la impugnación del derecho de resistencia y la restricción del derecho de ciudadanía. Los

\footnotetext{
${ }^{1}$ Universidad Nacional de Rosario - CONICET. Contacto: marilinmercedesgomez@gmail.com.
} 
problemas que surgen de la relación entre la concepción kantiana de la libertad y el imperativo del orden son objeto de un minucioso análisis en el estudio que aquí se reseña.

En el primer capítulo, Beade expone y analiza la libertad en la filosofía jurídica kantiana. A través de un riguroso desarrollo de conceptos centrales como lo son el de libertad de arbitrio, el de derecho y el de coacción, desarrolla la formulación kantiana de la libertad como ley universal, en tanto principio a priori de la razón práctica. Luego, ingresando en el ámbito específicamente jurídico, presenta la definición de libertad como único derecho innato del hombre, aludiendo a la libertad de expresión como inmanente a ese derecho inalienable.

En el capítulo dos, la autora despliega el contexto de la Ilustración y se dedica al análisis del uso público y el uso privado de la razón. Remarca que el uso público de la razón implica una publicidad que no tiene lugar "ante otros" sino "en compañía de otros". Se trata de una interacción comunicativa que supone una relación igualitaria entre autores y lectores. Con las exigencias de obediencia en el uso privado de la razón, a saber, aquello que es propio del desempeño de cierta función o puesto civil que se nos confía ( $W A$, Ak, VIII, 37), aparece la primera de las dificultades, en tanto aparentemente la libertad podría verse limitada. El análisis releva las implicancias de cada uno de los usos de la razón en varios textos kantianos, con un destacable apartado sobre "Kant como teórico de la publicidad" (2017: 113). La Öffentlichkeit ${ }^{2}$ es presentada como una instancia de perfeccionamiento constante y progresivo de la razón. De este modo, la autora considera a Kant un teórico de la opinión pública, quien habría dejado su huella en dicho ámbito señalando la insoslayable dimensión política de $l o$ público. La conclusión parcial sostiene que para que la razón pueda ser autónoma y crítica en su uso público, dicho uso ha de ser enteramente libre, pero equilibrado en el ejercicio de la crítica por una estricta limitación del uso privado. En el contexto ilustrado, pues, libertad y orden no harían sino articularse para garantizar la estabilidad del orden social, que es condición de todo progreso.

\footnotetext{
${ }^{2}$ Se trata de un término que puede traducirse al español como 'publicidad', 'vida pública', 'esfera pública', 'lo público' u 'opinión pública'. La primera y la última acepción son las preferidas de la autora en esta investigación.
} 
El tercer capítulo está dedicado al estudio de algunos conceptos fundamentales de la filosofía político-jurídica kantiana como contrato, Estado, voluntad pública, representación política, entre otros, con el objeto de reconstruir el marco de referencia del concepto jurídico de libertad. El desarrollo de estas cuestiones es exhaustivo y ofrece un paralelo con conceptos rousseaunianos que resulta esclarecedor. No obstante, surge en el desarrollo la segunda dificultad que se anunció al principio: la impugnación del derecho de resistencia. Beade analiza tres aspectos: el carácter inalienable del derecho de libre expresión, la distinción entre soberano y gobierno, leyes y decretos y, finamente, la distinción entre deberes éticos y deberes jurídicos. Como resultado de dicho análisis aparecen intersticios doctrinales, aperturas que habilitan a pensar como legítimas algunas formas de resistencia popular. Por último, discute la definición jurídica de libertad en el contexto político que delinea este capítulo, arribando a la conclusión de que los aspectos de independencia y autonomía (o indeterminación y autodeterminación) se hallan presentes tanto en el problema kantiano de la libertad política como en el tratamiento que realiza de la libertad en su dimensión metafísica y moral (2017: 203). En efecto, Kant define la libertad político-jurídica no solo como la independencia de un individuo frente al arbitrio constrictivo de otros, sino también como la capacidad de obedecer únicamente aquellas leyes a las que pueda darse consentimiento.

En el capítulo cuatro la autora ofrece, a partir del estudio de la libertad como autonomía en sentido político (como facultad de darse leyes a sí mismo), consideraciones conceptuales e interesantes críticas respecto a la distinción entre ciudadanos activos y ciudadanos pasivos. Es ineludible la resonancia que tienen las nociones analizadas en estas páginas frente a nuestra actualidad política y jurídica a nivel mundial, principalmente cuando aparece el cosmopolitismo y el hombre como ciudadano del mundo. Si bien este capítulo está destinado a tratar la tercera dificultad, a saber, la restricción del derecho de ciudadanía, cuestión que la autora trabaja profundamente, introduce el concepto de ciudadanía cosmopolita como esencial para el análisis y este cobra una relevancia imposible de soslayar para todo lector comprometido con la actualidad política social y económica del mundo.

El capítulo final presenta los principios fundamentales de la filosofía kantiana de la historia que constituyen el marco doctrinal en que se introduce el concepto de cosmopolitismo. Surge de la exposición que la obediencia a 
las leyes instituidas y a los poderes públicos que garantizan su cumplimiento no compromete la libertad individual sino que constituye la condición elemental para el ejercicio de esa libertad. La doctrina kantiana exige una articulación entre la libertad y las condiciones restrictivas que garantizan su pleno ejercicio. El progreso, en este marco doctrinal, solo es posible en un estado de derecho. Ahora bien, tanto el ejercicio de la libertad como el de una ciudadanía responsable requieren un aprendizaje. Pero no es posible madurar para la libertad sino por medio de la libertad misma, a través de un libre uso público de la razón. En efecto, la libertad en el uso público de la razón no puede ser restringida ni aplazada sin que por ello se vea obstruido el progreso de todo el género humano. Sin embargo, equilibrarla con una restricción en su uso privado no genera contradicción, sencillamente contribuye al sostenimiento del estado de derecho que es su condición de posibilidad.

A la luz de estas consideraciones doctrinales, la autora sostiene que la relación entre libertad y orden no hace más que evidenciar que la sujeción a la ley y al poder público no coarta la libertad jurídica del ser humano, sino que constituye su condición de posibilidad. Consecuentemente, dicha articulación resultaría indispensable en la doctrina kantiana, no solo para ejercer la libertad y la ciudadanía sino fundamentalmente para que el género humano logre sostener su marcha hacia el progreso.

Finalmente, nos gustaría remarcar que la investigación de la Dra. Beade, además de ser un texto riguroso y de consulta necesaria para quienes estudien la filosofía kantiana, resulta una provocación para re-pensar y criticar la situación política, jurídica, cultural, social y económica de nuestro mundo actual; un mundo con hombres y mujeres, con comunidades mundiales que son virtuales y fronteras nacionales cada vez más materiales. 


\title{
Christian Krijnen (Ed.): Metaphysics of Freedom? Kant's Concept of Cosmological Freedom in Historical and Systematic Perspective. Leiden/Boston, Brill (Critical Studies in German Idealism, vol. 23), 2018, 221 pp. ISBN: 978-90-40-38377-7
}

\author{
JACINTO PÁEZ
}

En un conocido pasaje de Los Progresos de la Metafisica, Kant advierte que la realidad de la libertad es, junto con la idealidad de las representaciones de espacio y tiempo, el sostén sobre el cual descansa la totalidad de la metafísica. Además de ocupar este rol arquitectónico, el concepto kantiano de libertad es complejo y polisémico, tal como lo muestra la coexistencia, en su teoría, de sus especificaciones como libertad transcendental - o cosmológica, libertad práctica, o arbitrio-. Al estudio de la primera variante mencionada está dirigido el libro editado por Christian Krijnen. El libro ofrece al lector tanto reconstrucciones sistemáticas de la teoría kantiana como así también el desarrollo de una perspectiva histórica, tanto en lo que refiere a la larga tradición filosófica desde la cual Kant parte, como a su proyección en los diversos sistemas del idealismo alemán y del neokantismo. El lector verá que es esta perspectiva histórica la que determina el orden de los capítulos del volumen y a la cual nos ceñiremos en nuestra síntesis del mismo.

El libro comienza acertadamente con el ensayo "Free Will in Antiquity and in Kant", escrito por Michael Forster. Para el autor, al concepto kantiano de libertad subyace la formulación originaria del pensamiento griego. Por tal motivo, dedica gran parte de su ensayo a realizar una genealogía del modelo que ha devenido estándar del pensamiento occidental en torno a la libertad. Este modelo, que define a la libertad como capacidad de elección entre cursos de acción alternativos, encuentra su expresión paradigmática en la conjunción, no necesariamente compatible, de las premisas estoicas y aristotélicas realizadas por Alejandro de Afrodisia. Independientemente del interés en sí de esta genealogía, Forster sostiene que

${ }^{1}$ Universidad Diego Portales. Contacto: jacintopaez.88@gmail.com. 
la misma permite comprender la distinción de Kant entre una libertad como espontaneidad y una libertad como autonomía en tanto reflejo del modelo antiguo. El aspecto positivo de esta propuesta es que disuelve el llamado problema de la imputabilidad en la filosofía práctica kantiana, pero lo hace con el costo de proyectar sobre ella las oscuridades argumentales de las fuentes griegas; oscuridades que, para el autor, la filosofía de Kant tampoco consigue clarificar de modo satisfactorio.

El segundo capítulo corre a cuenta de Gábor Boros y lleva por título "Freedom in Nature, Freedom of the Mind". El tema del capítulo es el concepto cosmológico de libertad de Spinoza. Boros señala que coexisten dos definiciones de la libertad en la Ética: existencia como siguiendo de la propia esencia (E1, D7) y como el amor constante y eterno de Dios (E5, P36, escolio). La estrategia del autor para interpretar su coexistencia consiste en exponerlas como una apropiación de dos antecedentes específicos: el voluntarismo de Descartes y el concepto de amor divino de León Hebreo. La posición propia de Spinoza aparece así como la combinación del proyecto cartesiano de una metafísica orientada hacia una imagen científica del mundo y una implementación de tal proyecto que recoge elementos del neoplatonismo judío. En cualquier caso, el capítulo ofrece una reconstrucción detallada de los argumentos y las críticas que llevaron a Spinoza a ofrecer un concepto original de libertad que se coloca en la vereda contraria del concepto cosmológico de libertad de Kant.

Thomas Hoffmann escribe "Kants theoretischer Freiheit und die Tradition der 'libertas spontaneitatis"'. La propuesta del capítulo consiste en reconstruir la constelación filosófica que oficia como punto de partida del concepto de libertad de Kant. Así, si bien Hoffmann reconoce el valor de la genealogía trazada por Forster previamente, también considera que el debate moderno adquiere una forma propia e irreductible a los modelos de los antiguos. Evidentemente, los autores modernos ya no comparten los presupuestos de la ontología aristotélica. A través de una serie de ejemplos históricos el autor expone el desarrollo racionalista de la idea de libertad como espontaneidad que en el período queda atada a la filosofía de Leibniz. Es precisamente la posición leibniziana el punto de partida de Kant en su Nova dilucidatio de 1755, aunque, ya en esta obra primeriza, la posición de Kant presenta matices propios. La última sección del capítulo considera el resultado de la 'tercera antinomia'. Hoffmann afirma que el verdadero 
rendimiento de Kant es haber alcanzado una noción de libertad como idea racional en su autorrealización y, entonces, un concepto de libertad que ya no pertenece exclusivamente al mundo de los entes.

El capítulo escrito por Klaus Erich Kaehler, "The Freedom of the Monad and the Subject of Freedom", propone una confrontación entre los conceptos de libertad de Leibniz y Kant. El concepto de libertad es el resultado sistemático de la construcción metafísica de Leibniz, por lo cual el Kaehler ofrece una síntesis muy compacta de la metafísica objetiva de aquel. La libertad es definida por Lebiniz como espontaneidad inteligente, la cual, en su grado máximo, se presenta en Dios. La libertad de la mónada creada no puede ser caracterizada como auto-creación - pero sí hay un concepto de libertad en analogía a la libertad creadora de Dios: como compromiso con una sujeción de la voluntad a la afirmación de una aprehensión racional- Kant mantiene el tipo de definición lebiniziana en la medida en que afirma el nexo entre razón y libertad pero desde la perspectiva de una auto-relación de la razón. La última sección del texto intenta mostrar cómo los argumentos kantianos desarrollan esta perspectiva sin recaer en un compromiso con una metafísica objetiva.

Heiner Klemme escribe "Das Problem der transzendetalen Freiheit und seine Lösung: Kant versus Wolff”. Como indica el título de modo explícito, Klemme presenta las peculiaridades del concepto kantiano de libertad transcendental a partir de una contraposición con la Deutschen Metaphysik de Wolff y con textos de Christian Garve. Klemme ofrece una amplia cantidad de referencias al tratamiento de la libertad racionalista en el marco de la metafísica especial (cosmología y teología) y también en el de la psicología empírica. En el caso de Garve, el tema de la libertad se presenta a través de una discusión de la antinomia entre fatalistas e indiferentistas que anticipa la antinomia kantiana — pero en un plano moral, no metafísico- El planteo de Garve se desenvuelve exclusivamente en terreno de la razón práctica $\mathrm{y}$, por ende, sin explicar cómo ella es teóricamente posible. Kant retorna con este concepto al terreno de la cosmología, pero, a diferencia de Wolff, prepara su respuesta provisto de la diferencia entre entendimiento y razón. La última sección del ensayo reconstruye los argumentos que Kant elabora a partir de este nuevo punto de vista. Como conclusión histórica del texto, podemos decir que el legado de Garve es la formulación del problema del cual el concepto de libertad transcendental es la respuesta. 
Stephan Zimmermann redacta el séptimo capítulo, "Kant on 'Practical Freedom' and Its Transcendental Possibility". Se trata de un largo estudio, exclusivamente dedicado a Kant, en el cual el lector encuentra como principal característica un análisis textual muy detallado. El principal problema interpretativo es la homonimia en el concepto kantiano, que hace necesario establecer una serie de distinciones terminológicas: libertad transcendental; libertad práctica; libertad empírica; arbitrio sensible e intelectual (según la Metafísica Pölitz); voluntad (Wille) y poder de elección (Willkür). Estos matices, sin embargo, se articulan siempre en función de una capacidad causal que tiene dos momentos, un momento determinativo y otro momento ejecutivo. Esta distinción es, en general, la clave hermenéutica utilizada por Zimmerman. El texto, de todas maneras, no registra solamente un plano descriptivo, sino que intenta mostrar que el problema más serio en torno al concepto de libertad es aquel de su posibilidad transcendental o el de su compatibilidad con la segunda analogía de la experiencia (posibilidad de la libertad en sentido empírico), lo que motiva al autor a abandonar la discusión del concepto de libertad en sentido moral para concentrarse en la discusión del determinismo natural, es decir, para regresar al problema cosmológico.

El capítulo octavo se titula "Absolute Spontaneity and SelfDetermination: The Fact of Reason and the Categories of Freedom", escrito por Martin Bunte. El autor continúa con la tónica del capítulo previo, ofreciendo comentarios extensos de pasajes tanto de la Crítica de la razón pura como de la Crítica de la razón práctica, pero moviéndose por fuera del tópico de la libertad cosmológica, en la medida en que la mayor parte de su preocupación concierne a la teoría del faktum de la razón. Destaca, en el capítulo, la explicación de la construcción lógica de la tabla de las categorías de la libertad, uno de los pasajes más oscuros de la segunda crítica, a partir de la idea de auto-determinación. Así, esta idea forma, aunque desde una óptica diversa, el núcleo teórico de ambas críticas.

Con el texto de Marina Bykova, "Kant's Problem with Freedom and Fichte's Response to the Challenge", el volumen pasa a considerar el legado de Kant. El problema al cual se refiere el título es el del carácter autooriginario de la acción libre, pues Kant no ofrece una prueba o explicación de su actualidad, sino solamente de su posibilidad. Para la autora, la virtud de Fichte consiste en ofrecer una teoría de la realidad de la libertad cosmológica a través del principio supremo de la filosofía: la auto-posición del yo. En este 
sentido, la autora defiende, a través de un comentario de la Doctrina de la Ciencia y del Sistema de Ética, que Fichte, frente a Kant, es un innovador en la teoría de la libertad en sentido cosmológico.

Faustino Fabianelli se encarga del capítulo décimo, titulado "Sameness and Otherness in the Free Principle of Philosophy: Fichte's Wissenschaftslehre in Comparison to Hegel's Science of Logic". El autor se embarca en una discusión teórica entre la filosofía de Fichte (interpretada como formulación de un pensamiento sobre lo absoluto en clave heterotética - un término técnico tomado del filósofo neokantiano Heinrich Rickert) - y la de Hegel (interpretada en términos de dialéctica). En el caso de Fichte, la libertad del principio de la Doctrina de la Ciencia es una libertad analógica, pues es la libertad de una imagen que se considera a sí misma como imagen del absoluto, mientras que, según el principio de la dialéctica, tal libertad analógica no es una libertad plena, pues se define gracias a su contrapartida, el absoluto, que permanece externo. Fabianelli se muestra partidario de la solución fichteana en la medida en que no reduce la realidad al poder del concepto, aunque la cuestión lamentablemente no es saldada con claridad en el texto.

El capítulo onceavo fue escrito por Christian Krijnen y se titula "Kant's Conception of Cosmological Freedom and its Metaphysical Legacy". La particularidad del ensayo consiste en considerar el concepto kantiano en función de su legado problemático. Como ha quedado claro para el lector a esta altura, el concepto kantiano revoluciona el modo de pensar la libertad sin dejar, por otra parte, de tener como lastre determinaciones conceptuales propias de la tradición metafísica. Krijnen analiza dos actitudes postkantianas frente a estas presuposiciones: el rechazo de Hegel y la transformación neokantiana. En el caso de Hegel, se niega que la libertad tenga el carácter de un poder causal, en el cuál ambos miembros de la relación solo están enlazados de modo externo. Para Hegel, aquello que es libre es el concepto y la libertad es auto-relación. Pero quizá lo más interesante para el lector hispano (probablemente también para el anglófono) sea la referencia al neokantismo, específicamente, a Bruno Bauch, el cual define en función de una de sus afirmaciones centrales, a saber, la concepción teórica de la normatividad. En la teoría de la acción de Bauch se explicita un modelo de causalidad que integra, a través del concepto de subjetividad concreta, tanto la causalidad natural como la causalidad por libertad. 
Desde su mismo título, "Hegel's Concept of Recognition as the Solution to Kant's Third Antinomy", el capítulo escrito por Arthur Kok plantea un argumento original para reconstruir la crítica de Hegel al concepto de libertad de Kant. El concepto de reconocimiento es la clave para comprender la posición de Hegel con respecto a la distinción entre fenómeno y cosa en sí y, por ende, para abordar el problema de la tercera antinomia kantiana, solo que ofreciendo una solución diferente al idealismo transcendental. Luego de establecer algunas críticas preliminares al idealismo transcendental kantiano, el autor introduce el concepto de reconocimiento propio de la dialéctica entre el amo y el esclavo, el cual es reconstruido de modo minucioso. En el marco de esta reconstrucción, el autor presenta una visión crítica de la interpretación tradicional en la medida en que la explica no como la confrontación de dos auto-conciencias, sino como dos perspectivas propias de la autoconciencia. Lo que el argumento logra, a fin de cuentas, es disolver el fondo problemático que da lugar a la antinomia. En cualquier caso, el texto tiene la virtud de colocar bajo una nueva luz, la del problema de la libertad cosmológica, el conocido capítulo de la Fenomenología del espíritu.

La edición concluye con "Does Spontaneity have to be Naturalized? Freedom as Spontaneity-Today and in Kant", escrito por Jakub KlocKonkolowicz. Al hablar de espontaneidad naturalizada, el autor se refiere al significado antropológico o cotidiano que porta este concepto. La preponderancia de una visión antropológica es atribuida a autores contemporáneos como Arendt, Habermas y Nussbaum, pues interpretan la espontaneidad como un concepto fundamental en la filosofía moral, pero lo interpretan como una propiedad social que debe ser adquirida a través de un proceso de mediación colectivo. Pero por sobre la determinación social, que para el autor permanece siempre externa al actor, se encuentra la determinación individual. Y solo bajo esta determinación, la espontaneidad permanece como una posibilidad para todo sujeto, con independencia de su situación histórica concreta. Si la crítica de Kloc-Konkolowicz es correcta, es finalmente el concepto transcendental aquel que, en un sentido relevante, termina siendo el más inclusivo. De esta manera, el volumen consigue un cierre orgánico, pues además de haber reconstruido a lo largo de sus capítulos los distintos contextos históricos en los cuales el concepto de libertad cosmológica ha jugado un rol, nos permite evaluar incluso en qué sentidos puede aún participar en las discusiones más contemporáneas. 
Es posible que, al considerar el índice del volumen, el lector eche en falta un capítulo exclusivamente dedicado a la reconstrucción del tercer conflicto antinómico de la razón pura. Por el contrario, todos los capítulos, aún los de mayor pretensión sistemática, intentan situar al concepto de Kant en un diálogo con la tradición filosófica. Lo que esto significa, aunque sea implícitamente, es que nuestra apropiación del pensamiento kantiano ya no puede realizarse sin considerar la mediación del pensamiento post-kantiano. Podemos decir, como conclusión, que la armonía entre el desarrollo histórico y la sutileza de las reconstrucciones sistemáticas es lo que hace muy valioso a este volumen y que interesará por igual a quien indaga en aspectos técnicos del concepto moderno de libertad como a quien busca obtener una visión de conjunto del tema, tomando como punto focal, en este caso, la doctrina de Kant. 


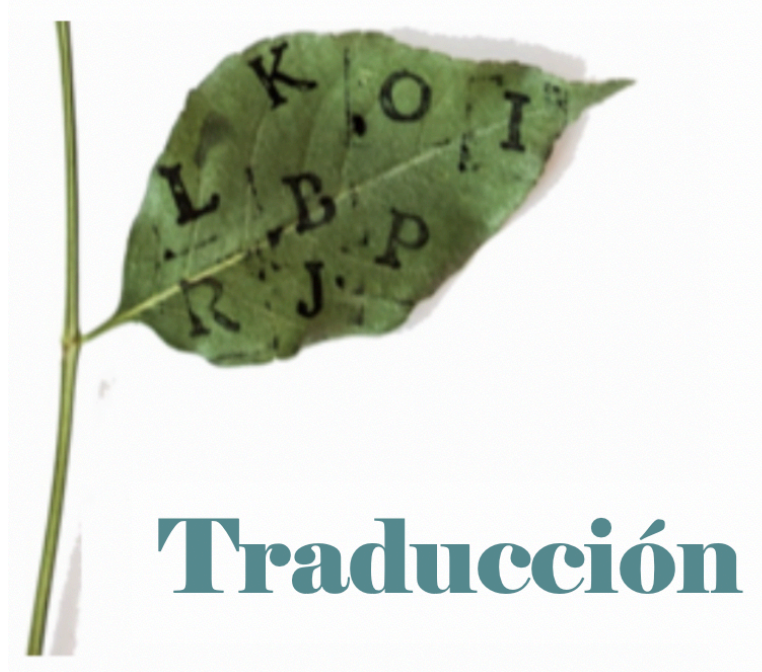




\title{
Salomon Maimon frente a la filosofía trascendental. Traducción de algunas cartas sobre su filosofía teórica
}

\author{
DAVID HEREZA MODREGO ${ }^{1}$
}

\begin{abstract}
Resumen
Este artículo ofrece una introducción y traducción de las tres cartas de Salomon Maimon más relevantes, dada su claridad y concisión, para entender su relación con la filosofía trascendental kantiana: la primera carta enviada a Kant (1789) y las últimas del intercambio epistolar ficticio "Cartas de Filaletes a Aenesidemus" (1794). Con ello, nuestra intención es poder procurar una visión de conjunto de los elementos fundamentales de su filosofía teórica.
\end{abstract}

Palabras clave: filosofía teórica, filosofía trascendental, Salomon Maimon

Salomon Maimon on transcendental philosophy. Translation of some letters on his theoretical philosophy

\begin{abstract}
This article offers the introduction and translation of the three most relevant letters of Salomon Maimon, given its clarity and conciseness, in order to understand his relation with Kant's transcendental philosophy: the first letter sent to Kant (1789) and the last fictional letters of the text "Letters from Filaletes to Aenesidemus" (1794). Thus, our intention is to offer an overview of the fundamental elements of his theoretical philosophy.
\end{abstract}

Keywords: theoretical philosphy, transcendental philosophy, Salomon Maimon

\footnotetext{
${ }^{1}$ Universitat de València. Contacto: david.hereza@uv.es. Este trabajo ha sido redactado en el marco del proyecto de investigación financiado por el Ministerio de Educación de España FFI2017-82195-P de la AEI/FEDER, UE, y con el apoyo de una beca estatal F.P.U. (FPU15/05250).
} 
1. Introducción a los textos traducidos y motivos de su elección

La convicción general en torno a la que giran los esfuerzos de S. Maimon (1753-1800)² —y de buena parte de los intelectuales coetáneos a él— es solo una: la filosofía trascendental aún necesita de ciertas modificaciones en su argumentación si quiere ser efectivamente ciencia de los "principios del conocimiento humano" y, por lo tanto, "reforma de la metafísica" hecha hasta entonces, como esperaba Kant (AA XI: 54). Bajo tal idea están escritas las tres cartas que aquí presentamos traducidas por primera vez al castellano.

Los textos elegidos han sido extraídos de dos momentos diferentes de la producción del autor, cuyo contraste a veces es pasado por alto en los estudios especializados. El primero corresponde a su contacto inicial con el pensamiento kantiano, etapa que quedará plasmada en el Versuch über die Transzendentalphilosohie [Ensayo sobre la filosofia trascendental, VT] (1790). ${ }^{3}$ El breve resumen de esta obra, enviado a Kant junto con una copia del libro, es el primero de los documentos que aquí presentamos traducidos. El segundo momento representa lo que podríamos denominar su 'último acto' en el debate en torno al criticismo, que nuevamente quedó inmortalizado con la publicación de un Ensayo, esta vez el Versuch einer neuen Logik oder Theorie des Denkens [Ensayo sobre una nueva lógica o teoría del pensar, $V n L]$ (1794). En el apéndice de este tratado se encuentran unas cartas ficticias impregnadas de la disputa de la época ("Cartas de Filaletes a Aenesidemus") de las cuales hemos traducido las dos últimas. En ellas - como apuntábamos - nos encontramos un autor distinto respecto al de 1789, en lo concerniente al contenido y a la forma. Y no es para menos: el panorama de la discusión filosófica había mutado velozmente $\mathrm{y}$, con él, los pensadores involucrados (v. Frank 2007). Así pues, merece la pena detenerse brevemente en las diferencias y similitudes que podemos observar en el contenido de las traducciones aquí presentadas.

Más allá de lo anecdótico que puedan representar las fechas de estos textos para situar la primera discusión post-kantiana (1789-1794), la unidad

\footnotetext{
${ }^{2}$ Sobre una introducción biográfica al autor ya existen en castellano contribuciones a las que remitimos al lector: Duque 1987; Hoyos 2001. En la primera traducción aquí realizada el lector también podrá encontrar una breve pero interesante autodescripción por parte de Maimon.

${ }^{3}$ Todas las obras de Maimon han sido publicadas por Verra en una Gesammelte Werke editada por Georg Olms en 1970, si bien esta edición se limita a reimprimir los textos fotomecánicamente de forma unitaria. Desde hace tiempo, algunos especialistas de este autor han insinuado el proyecto de una edición crítica de la obra completa de Maimon, pero este aún no ha visto la luz. Para más información sobre el autor o la bibliografía sobre el mismo, véase el contenido de http://www.salomon-maimon.de/.
} 
de ellos reside en la claridad y concisión que poseen frente al carácter desordenado y algo confuso habitual de las obras de Maimon. Por ejemplo, la importancia de la carta de 1789, además de permitir un acercamiento a la figura de Maimon, reside en su forma de exposición, la cual — siguiendo las palabras de M. Frank - "de manera proporcional a lo caótico" que es el libro al que acompaña (es decir, el $V T$ ), "es un resumen claro y preciso del mismo" (1997: 116). Lo mismo podría afirmarse del segundo de los escritos aquí presentados. Maimon tiene la pretensión de haber condensado en él sus críticas principales a Kant y, sin duda, este representa el documento más inteligible de su producción filosófica teórica. ${ }^{4}$ Además, como indica en el prólogo al $V n L$, estas cartas permiten obtener una "visión de conjunto" de la reforma de la lógica trascendental que se propone en el seno de la polémica entre Reinhold y Schulze:

Las añadidas Cartas de Filaletes a Aenesidemus tienen como meta, por una parte, superar las objeciones de Aenesidemus contra la filosofía crítica en general, por otra, exponer, en lo esencial y de forma breve, las lagunas y carencias que creo haber descubierto en la filosofía crítica, así como el modo mediante el cual he intentado en esta obra $[V n L]$ solucionar aquellas y mejorar esta. Especialmente las dos últimas cartas [sexta y séptima] pueden ofrecer al lector una visión de conjunto completa de toda la obra (VnL, XXVIII).

Con ellas, pues, se trata de apuntalar una nueva interpretación del proyecto kantiano que permita evitar el escepticismo radical (Schulze) ${ }^{5} \mathrm{y}$, al mismo tiempo, enmendar la filosofía de un 'único principio' o Elementarphilosophie (Reinhold) sin perder su pretensión de cientificidad (Hoyos 2001; Hereza 2016). La idea de crear un debate epistolar ficticio seguramente la extrajo Maimon del libro del primero (publicado anónimamente en 1792). Este consistía en la simulación de un diálogo entre dos personajes: Aenesidemus (representante del autor), partidario del escepticismo, y Hermes (de Reinhold), fiel defensor del criticismo. Es a esta discusión a la que quiere unirse Maimon bajo la figura de Filaletes — nombre que ya usó Leibniz para entablar otra disputa ficticia con Locke - y con él poder contraponerse a los dos interlocutores.

\footnotetext{
${ }^{4}$ También lo es el texto de 1801, publicado después de la muerte del autor y disponible en Oncina 1992. ${ }^{5}$ Sobre Schulze, las referencias son muy escasas en lengua castellana, pero hay excepciones: véase Hoyos 2001.
} 
Esto pone en evidencia una nítida distinción entre el contenido de los dos textos y, con ellos, de la producción de 1789 y 1794. Se abandona una solución a là Spinoza propia del VT, que tanto atrajo a los neokantianos y con la que pretendía resolver el problema cardinal del criticismo mediante ciertas ideas del entendimiento que hiciesen referencia a la totalidad material (v. Cassirer 1920: 97-104). A la altura de 1794, la propuesta consiste más bien en una alternativa al principio de la conciencia de Reinhold [Satz des Bewußtseyns] que pudiese hacer frente a las críticas de Schulze. De ahí nace la función esencial que adquiere el Satz der Bestimmbarkeit [principio de determinabilidad] para la reforma de la filosofía mencionada en estas cartas (especialmente en la séptima). Ahora bien, aunque diferentes en sus soluciones, estos dos momentos de la producción de Maimon están marcados por una única pregunta a la que siempre merece la pena prestar atención: 'quid facti?'. La comprensión de este problema es la clave para entender el interés que despertó y aún aviva las reflexiones de este singular pensador judío.

Como es sabido, Kant había pretendido responder a la cuestión 'quid juris?' respecto al uso de los conceptos puros ( $K r V$ A84/B116ss). Sin embargo, según Maimon, este interrogante no obtiene una respuesta definitiva en la Crítica de la razón pura por un problema que puede ser abordado desde dos perspectivas (y que el lector podrá encontrar claramente expresado en los escritos que presentamos).

Por un lado, la solución que Kant da en su 'deducción' es insuficiente porque este se limita a ofrecer una explicación de cómo es pensable una unión entre conceptos puros (categorías) e intuiciones empíricas (objetos) sin, con ello exponer que esto realmente suceda (quid facti), lo que en última instancia no permite superar el escepticismo de Hume. ${ }^{6}$ Esta tensión argumentativa no resuelta por Kant está latente en la misma Crítica, cuando se anuncia la 'heterogeneidad' entre conceptos puros e intuiciones ( KrV A137/B176; VT 54) para luego afirmar su unión mediante la oscura noción de 'esquema' $\mathrm{KrV}$ A138/B177). En pocas palabras: incluso si el resultado de tal deducción podría ser lógicamente así (quid juris), no se sigue que de hecho lo sea (quid facti).

\footnotetext{
${ }^{6}$ No debe ser confundido este uso de la expresión 'quid facti' con el que el mismo Kant hace para críticar el modo de derivar genético de Locke. Sobre los detalles de esta crítica de Maimon a Kant, nos remitimos a un libro clásico de los estudios sobre Maimon: Engstler 1990.
} 
Por otro lado, esta misma crítica (quid facti) es utilizada por Maimon para hacer frente a una posible solución que Kant señala en algunos pasajes con el fin de superar el problema que supone el capítulo del esquematismo. En vez de plantear este como una dificultad, el filósofo de Königsberg a veces expone su proyecto a partir de la aceptación inicial del factum de la experiencia reglada que queda asegurado en el conocimiento físicomatemático. ${ }^{7}$ Así, la filosofía trascendental kantiana consistiría en el análisis de ese hecho que, por tanto, no requeriría ser explicado: lo que se siga de él debe ser asumido como parte del sistema. Sin embargo, la falta de fundamentación de ese factum es la otra cara de la objeción que adquiere el nombre de quid facti, pues con tal solución solo se desplaza el problema de la realidad de los conceptos puros sin llegar a resolverlo.

El proceder de la Crítica es el siguiente: I. Explica la diferencia entre juicios analíticos y sintéticos; contra la cual no tengo nada que objetar. II. Establece como un factum indudable de la conciencia que todas las ciencias teoréticas (matemática, ciencias naturales) contienen juicios sintéticos a priori. III. Se plantea la pregunta: ¿Cómo son, en general, posibles los juicios sintéticos a priori? (VnL 470/412; Prol., AA IV, 280).

El lector podrá comprobar la solución radical de Maimon a este problema: la reforma del sistema trascendental pasa por la afirmación del escepticismo frente a ciertas pretensiones del conocimiento sin renunciar con ello a la posibilidad de obtener certeza en algunos principios. El fundamento último de tal certeza, que Maimon equipara al pensar real, es el 'principio de determinabilidad'. Este no pretende ser otra cosa que el análisis del acto que se presupone en todo enjuiciamiento sintético en general: a saber, que la relación entre sujeto y predicado en un juicio sea tal que el primero sea independiente del segundo, pero no al contrario. A partir de aquí, por primera vez después de Kant y como claro antecedente de Fichte, se intenta derivar las categorías fundamentales del pensar desde un principio que permita - como ya se ha dicho - una salida al callejón que representaban el escepticismo de Schulze y la fundamentación última de Reinhold.

\footnotetext{
${ }^{7}$ Con estas consideraciones nos remitimos meramente a la lectura que Maimon hace de Kant a lo largo de su obra (véase por ejemplo $V T$ 6, 186), dejando abierta la cuestión de si este último realmente utiliza tal tipo de argumentación.
} 
Ahora bien, más allá de estas similitudes y diferencias apuntadas, los textos aquí traducidos ponen de relieve otras cuestiones importantes para la comprensión de los problemas de la filosofía kantiana y la inteligibilidad del paso de ésta al Idealismo alemán. Aún queda mucho trabajo por realizar en ambos sentidos, y la convicción de que lo presentado a continuación puede ayudar a tal tarea es el motivo de esta contribución. Por ello, esperamos que junto con las traducciones ya hechas (Oncina 1987, 1992), la publicación de las siguientes cartas permita al lector hispanohablante hacerse una nutrida idea de la filosofía de Maimon; algo que posibilitará continuar de una forma más acabada el trabajo emprendido aquí.

\section{Consideraciones sobre las traducciones realizadas}

En lo que respecta a la primera carta (A), el texto se encuentra disponible, tanto en el volumen VI (423-425) de la Gesammelte Werke de S. Maimon, editada por Valerio Verra, como en la Kant's gesammelte Schriften: carta ${ }^{\circ}$ 352, contenida en el Volumen XI (15-17). Dentro del texto se ha señalado empleando corchetes la referencia a la paginación de la Gesammelte Werke de Maimon, así como de la Akademiausgabe de Kant (idénticas en los cortes al ser la primera copia fotomecánica de la segunda); primero se indica la edición de la Gesammelte Werke, luego la de la Akademiausgabe siguiendo el modelo GW/AA.

En lo que respecta a las Cartas a Aenesidemus (B), la versión original del texto se encuentra reproducida fotomecánicamente del original de 1794 en el Volumen V (461-494) de la Gesammelte Werke de S. Maimon, editada por Valerio Verra (también hay ediciones del texto siguiendo el mismo tipo de reproducción en la Wissenschaftliche Buchgesellschaft y en la edición de Bernhard Carl Engel para la Kantgesellschaft).

Dentro del texto se ha señalado entre corchetes la referencia a la paginación de la Gesammelte Werke, así como a la paginación original de la obra editada en 1794 (idénticas al ser la primera copia fotomecánica de la segunda). Para la traducción, además, hemos seguido las correcciones gramaticales del alemán de Maimon ofrecidas por B. C. Engel en su edición del texto sin señalar las modificaciones respecto al original. También, siguiendo el estilo de la traducción inglesa (di Giovanni 2000), siempre se ha optado por un resultado de la traducción más legible posible. Para ello, 
cuando el sentido del texto no era claro, se han acotado algunas frases mediante comillas inglesas o se ha añadido entre corchetes algún 'es decir' o alguna referencia del tipo 'este, aquella, etc...' o 'la primera, segunda, etc...' cuando Maimon se limita a introducir una coma. Con esto, sin embargo, no se ha añadido algo no dicho por el autor o se ha efectuado algún tipo de paráfrasis. $^{8}$

\section{Referencias}

CASSIRER, E.: Das Erkenntnisproblem in der Philosophie und Wissenschaft der neueren Zeit, Bd. III, Berlín: Verlag Cassirer, 1920.

DI GIOVANNI, G.; HARRIS, H. S. (Eds.): Between Kand and Hegel: Text in the Development of Post-Kantina Idealism, Indianapolis, Hackett Publishing, 2000.

DUQUE, F.: "Historia y metafísica: El frágil espejo móvil de la razón. Contribución al estudio de la Aetas kantiana: 1790-1797”, en KANT, I.: Los progresos de la Metafísica desde Leibniz y Wolff, Madrid, Tecnos, 1987.

ENGSTLER, A.: Untersuchungen zum Idealismus Salomon Maimons, Stuttgart-Bad Cannstatt, Frommann-Holzboog, 1990.

FRANK, M.: Unendliche Annäherung: Die Anfänge der philosophischen Frühromantik, Frankfurt am Main, Suhrkamp, 1997.

: "Philosophie als unendliche Annäherung. Überlegungen im Ausgang von der frühromantischen Konstellation", en FRANK, M.: Auswege aus dem Deutschen Idealismus, Frankfurt am Main, Suhrkamp, 2007.

: Filosofía como «aproximación infinita». Consideraciones a partir de la «constelación» del primer romanticismo alemán, HEREZA MODREGO, D. (trad.), Análisis. Revista de investigación filosófica 2, 2 (2015) 311-333.

HEREZA, D.: "Sobre la posibilidad de la filosofía como ciencia rigurosa de K. L. Reinhold", Revista de Estudios Kantianos 1, 1 (2016) 85-97.

HOYOS, E.: El escepticismo y la filosofia trascendental: estudios sobre el pensamiento alemán a fines del siglo XVIII, Bogotá, Siglo del Hombre, 2001.

\footnotetext{
${ }^{8}$ Agredecemos a Maria Caterina Marinelli (Università di Roma Tor Vergata/Ludwig-Maximilian München Universität) su importante ayuda en el prceso de revisión y edición final de la traducción.
} 
KANT, I.: Kant's gesammelte Schriften, Berlín, Königlich Preußischen/Deutschen/Berlin-Brandenburgischen Akademie der Wissenschaft, 1902.

MAIMON, S.: Gesammelte Werke, Hildesheim, Georg Olms, 1970.

: Versuch einer neuen Logik oder Theorie des Denkens, Berlín, Reuther \& Reichard, 1912.

: Versuch einer neuen Logik oder Theorie des Denkens, Darmstadt, Wissenschaftliche Buchgesellschaft, 1963.

: "Lettere di Filalete a Enesidemo", Studi urbinati 2 (1967) 601-641.

ONCINA, F.: "S. Maimon: el divertido baile", Er. Revista de filosofía 5 (1987) 181-197.

: "Salomón Maimon: Un francotirador en el pensamiento crítico", Revista venezolana de Filosofía 27 (1992) 89-130.

SCHULZE, E. G.: Aenesidemus oder über die Fundamente der von Herrn

Professor Reinhold in Jena gelieferten Elementar-philosophie, Hamburg, Meiner, 1792.

\section{A. Traducción de Carta de Maimon a Kant (1789)}

[423/15] ¡Venerable hombre!

Consciente de la profunda deferencia que un hombre debe a quien ha reformado la filosofía y, mediante ella, cada una de las ciencias, solo el amor a la verdad ha sido lo que me ha hecho tener el valor suficiente para acercarme a usted. Destinado ya desde mi nacimiento a pasar los mejores años de mi vida en los bosques lituanos, [424/16] privado de todo medio que pueda ayudar a alcanzar el conocimiento de la verdad, llegar a Berlín fue para mí suficiente motivo de satisfacción, aunque fuese tarde. Aquí, mediante el apoyo de algunas nobles personas conseguí las condiciones para dedicarme a las ciencias; era natural, creo yo, que, en mi situación, el intenso deseo de alcanzar mi meta principal, la verdad, mi hiciese desatender otras subordinadas: el conocimiento de la lengua, el método, etc. De ahí que no me atreviese a presentar públicamente algunos de mis pensamientos a este actual mundo de gusto refinado, curiosamente, a pesar de haber leído y reflexionado sobre numerosos sistemas filosóficos y, con ello, haber encontrado algo nuevo en los mismos. Finalmente, tuve la fortuna de dar con sus inmortales obras, de estudiarlas y de reformar mi modo de pensar en su totalidad a partir de las mismas. Me he esforzado extraordinariamente en extraer los últimos 
resultados, retenerlos en mi memoria y trazar el camino que recorre el curso principal de las ideas para poder así penetrar en el espíritu del autor. Con esta meta, apunté los resultados tal y como los iba comprendiendo, y añadí algunas observaciones que afectan, principalmente, a los siguientes puntos:

1) La diferencia que usted da entre proposiciones analíticas y sintéticas, y la realidad de estas últimas.

2) La pregunta Quid Juris? Esta pregunta era por su importancia digna de un Kant, y si se le da la extensión que usted mismo le ha dado, se pregunta: ¿cómo puede ser aplicado con certeza algo a priori a algo a posteriori? Y así, la respuesta o «deducción» que nos da en sus escritos es totalmente satisfactoria, como solo podía ser la de un Kant. Sin embargo, si se quiere seguir ampliando la cuestión, se pregunta: ¿cómo puede ser aplicado un concepto a priori a una intuición aunque esta sea una intuición a priori? Aquí la pregunta solo debe esperar al maestro otra vez para ser respondida de forma satisfactoria.

3) Un nuevo tipo de ideas, que llamo ideas del entendimiento y que hacen referencia a la totalidad material, como las ideas mencionadas por usted hacen referencia a [425/17] la totalidad formal. Con ello creo haber abierto una nueva perspectiva para responder a la mencionada pregunta Quid Juris?

4) La pregunta Quid facti? - esta parece haberla mencionado usted sin más; pero debido a la duda humeana me parece realmente importante responderla satisfactoriamente.

Estas observaciones constituyen, de forma breve, el contenido del manuscrito que me he atrevido presentarle a usted. ${ }^{9}$ Mis bondadosos amigos me insisten desde hace tiempo a hacer público tal escrito, pero no quería complacer sus deseos sin que usted me haya dado su tan estimable juicio. Si un Kant no encontrase vano un esfuerzo tal, entonces él no despreciaría ciertamente a aquel que se le acerca noblemente. Él le responderá, le enseñará dónde falla, o, si lo debiese encontrar digno, le rendirá la aprobación y le hará el doble de dichoso.

\footnotetext{
${ }^{9}$ El manuscrito en cuestión, como se indica en la introducción del artículo, es el ya mencionado Versuch über Transzendentalphilosophie, publicado el año siguiente al envío de esta carta.
} 


\section{B. Traducción de Cartas de Filaletes a Aenesidemus (1794)}

$[461 / 403]$

\section{Carta Sexta}

En la carta precedente ${ }^{10}$ mi intención fue mostrar que son infundadas las lagunas, carencias e imperfecciones que el señor Reinhold cree haber encontrado en la Crítica de la Razón y haber mejorado en su Teoría de la facultad de la representación. Ahora quiero presentar a su consideración y a la de todo librepensador las lagunas, carencias e imperfecciones que yo he encontrado en ella y el modo según el cual he intentado mejorarlas en [462/404] mi Crítica de la facultad del conocimiento.

I. La Crítica de la Razón ha mostrado el paso de la lógica a la filosofía trascendental, del pensar formal al pensar real [reelles Denken]. Sin embargo, no ha mostrado cómo la lógica misma ha llegado a alcanzar la dignidad de una ciencia sistemática basada en principios universalmente válidos.

La Crítica de la Razón presupone la lógica como una ciencia desde hace tiempo terminada; ciencia que desde Aristóteles no habría necesitado dar ningún paso hacia atrás y que, hasta el momento, no habría podido dar ninguno hacia delante. Sus axiomas (el principio de contradicción y el de identidad) son necesarios y universalmente válidos; sus postulados (las posibles formas del pensar) están fundados en sí mismos y negativamente en los axiomas (no contradicen los axiomas) y están determinados mediante la sola reflexión sobre el pensar en general de tal modo que no pueden ser objetos de ninguna ampliación, disminución o esencial mejora. Sus teoremas son derivados a partir de axiomas y según los mismos. Una vez presupuesto esto, la Crítica de la Razón investiga la posibilidad del pensar real, es decir,

\footnotetext{
${ }^{10}$ Maimon se refiere a la quinta carta de la correspondencia ficticia que concluye con las dos cartas siguientes. Para su contexto, remitimos a la primera parte de este artículo.
} 
[la posibilidad] de la atribución de las formas, meramente posibles en relación a un objeto [463/405] en general, a los objetos externos al pensar dados de un modo determinado. En lo que respecta a los objetos determinados a priori (de la matemática), ella encuentra el fundamento de tal posibilidad en la posible exposición a priori (a saber, en el hecho de que los objetos no pueden ser expuestos sino mediante formas determinadas mediante el pensar, o con otras palabras, de que pueden ser construidos); en lo que respecta a objetos empíricos, [el fundamento de tal posibilidad lo encuentra] en la posibilidad de la experiencia en general. (Se nota inmediatamente la diferencia entre estos dos tipos de explicación. El fundamento por el cual afirmo universal y apodícticamente, por ejemplo, el predicado «tres ángulos» del sujeto «una figura de tres lados», es la imposibilidad de construir una figura de tres lados que no tenga tres ángulos. Sin embargo, el fundamento por el cual, por ejemplo, pienso el fuego como causa del calentamiento de la piedra, no está en el hecho que el «fuego» y el «calentamiento de la piedra» solo puedan ser expuestos como estos objetos determinados en esta relación, sino iporque en tal relación solo es posible la experiencia en referencia a objetos en general!) Ella muestra que las formas del pensar son usadas por objetos determinados de la experiencia solo como condiciones de la posibilidad de la experiencia en general, etc.

[464/406] Sin embargo, yo he mostrado que las formas lógicas, abstraídas de su significado trascendental, no tienen significado alguno. Pediría a cualquier filósofo que me diera, por ejemplo, el significado preciso de la afirmación y la negación lógica abstraídas de sus correspondientes conceptos trascendentales de «realidad» y «negación». Por «afirmación» no puedo pensar otra cosa que una cierta relación entre sujeto y predicado mediante la cual es determinado un pensar real objetivo (si bien no siempre un objeto real). En cambio, por «negación» [pienso] una relación mediante la cual se suprime [aufgehoben] un pensar real objetivo, quedando así solo un pensamiento subjetivo de esa misma relación. Pienso, por ejemplo, un «triángulo rectángulo», es decir, afirmo del «triángulo» que «puede ser rectangular»; con ello, el «triángulo» es determinado como un objeto real, es decir, es producida una realidad. Pienso la figura «triángulo» teniendo «tres ángulos», o afirmo de la figura «triángulo» que debe tener «tres ángulos». Con ello, no se ha determinado ningún objeto nuevo, pero sí una nueva característica del mismo fundamentada en el objeto y, del mismo modo, una realidad. E incluso en los casos donde el sujeto en sí no tiene ninguna 
realidad, y por lo tanto mediante la atribución de un predicado no puede ser determinado ni un objeto ni una característica (al no [465/407] poder tener una «nada» ninguna característica), el pensar mismo sí que puede tener una realidad fundamentada en el objeto en tanto que este es pensado como realidad. Como en el ejemplo: «un decaedro regular es regular». Un «decaedro regular» es, de hecho, imposible como objeto, pero ya que, no obstante, es pensado como posible, el pensarlo como «regular» sí tiene realidad objetiva según el principio de no contradicción, si bien con ello no sea determinado ni un objeto real ni una característica del mismo.

$\mathrm{Si}$, por contra, niego al «triángulo» el «ser cuadrangular», pongo de manifiesto con ello que el «ser triángulo» y «ser cuadrangular» están en una relación que consiste en suprimirse mutuamente, y que no puedo pensarlos en una unidad objetiva de la conciencia, sino meramente en una subjetiva (identidad de la autoconciencia) y que estos, pensados en una unidad objetiva de la conciencia, tienen como consecuencia una negación.

Por lo tanto, la realidad y negación lógica y relativa (afirmación y negación) presuponen la [realidad y negación] trascendental y absoluta, pues si no, no tienen ningún significado, y así ocurre con todas las otras formas. Por lo tanto, lejos de que la lógica preceda a la filosofía trascendental, esta debe preceder a aquella.

[466/408] La Crítica de la Razón hace justamente lo contrario; esta (con la excusa de tratar la lógica pura y separada de la filosofía transcendental) acepta las formas lógicas como inmejorables -tal y como fueron abstraídas arbitrariamente a partir de su supuesto uso práctico por su primer descubridor- y las pone como fundamento de la filosofía trascendental si bien no pueden tener ni una correcta determinación, ni completitud, ni significado, ni fundamento sin una crítica previa.

De que esta objeción que hago a la Crítica de la Razón está fundamentada puede usted convencerse fácilmente a partir del modo en el que esta se sirve de las formas lógicas como hilo conductor en la búsqueda de las categorías; tal acusación es la que, brevemente, quiero presentar a su consideración.

En primer lugar, la Crítica de la Razón divide, en primer lugar, las formas de los juicios en cuatro momentos principales: cantidad, cualidad, relación y modalidad, cada uno de los cuales contiene a su vez tres formas. 
Esto lo presupongo como sabido. Ahora bien, señalo: (1) que las formas de la cantidad no son esenciales a los juicios originarios (aquellos no derivados de otros), al no tener los juicios originarios, de hecho, ninguna cantidad. Los juicios que tienen una cantidad, aun pareciendo juicios originarios, solo son de hecho conclusiones de silogismos abreviados. ¿Qué otro fundamento puede tener este juicio analítico universal, por ejemplo, «todo $a b$ es $a$ » (todo ser humano o todo animal, que sea determinado como «ser humano», es animal) sino el hecho de que, en primer lugar, veo inmediatamente que «a» está contenido en «ab»y, de nuevo, que «ab» está contenido en todos «ab» (abc, abd, abe, etc.)? Lo que hago aquí es unir dos juicios analíticos originarios sin ninguna cantidad a partir de los cuales derivo mediatamente un juicio dado en forma universal. En el juicio sintético universal: «todos los a son b» (por ejemplo, «todas las figuras de tres lados tienen tres ángulos») uno el juicio sintético «a es b» («una figura de tres lados tiene tres ángulos») sin ningún tipo de cantidad con el juicio analítico: «todos los a son a» («todas las figuras de tres lados tiene tres lados») y así sucede también con todos los presuntos juicios originarios; considerados como juicios simples no tienen ningún tipo de cantidad.

(2) Según la cualidad, los juicios son divididos en juicios afirmativos, negativos e infinitos. Estos últimos, sin embargo, no componen ninguna clase especial de juicios según el significado y el valor que se les ha atribuido hasta el momento. «A no es $\mathrm{B}$ » es un juicio negativo, $\mathrm{y}$ « $\mathrm{A}$ es no-B» uno infinito que debería tener el mismo valor que aquel. Estos dos tipos de juicios [468/410] se diferencian, por lo tanto, nominalmente pero no esencialmente.

(3) Según la relación, los juicios son divididos en juicios categóricos, hipotéticos y disyuntivos. Sin embargo, los juicios hipotéticos no tienen ni significado ni un uso diferente al de los categóricos. Depende de mi voluntad el que cada uno de estos juicios reciba, según el gusto de cada uno, el nombre de «categórico»o «hipotético». Por ejemplo, en vez del juicio categórico «la suma de los ángulos de un triángulo es igual a dos ángulos rectos», se puede formular hipotéticamente: «si una figura es un triángulo, entonces, la suma de sus ángulos es igual a dos ángulos rectos», y lo mismo sucede en otros casos. Por lo tanto, llegamos a la forma de los juicios hipotéticos meramente a partir de su supuesto uso en la experiencia; uso que, sin embargo, el escéptico no acepta y que explica como una mera ilusión. Y, no obstante, aquí se apoya fuertemente la Crítica de la Razón. De este modo, esta cae en una 
clara circularidad: ella toma una forma cuyo origen la lógica no puede legitimar y que es abstraída de su supuesto uso en la experiencia, y la pone nuevamente como fundamento del uso en la experiencia sin ningún tipo de crítica previa.

(4) Según la modalidad, los juicios son divididos en juicios apodícticos, problemáticos y asertóricos. [469/411] «Juicios apodícticos» son (a) todos los juicios analíticos, (b) los juicios sintéticos que son determinados como necesarios mediante construcción. «Juicios problemáticos» son llamados o aquellos en los que la unión de sujeto y predicado es determinada de forma positiva, como posible, o aquellos en los que tal unión mediante construcción es determinada, al menos, de forma negativa (como no imposible). Pero, ¿qué significan los «juicios asertóricos»? Los lógicos me pondrán este juicio, por ejemplo: «Alejandro es hijo de Filipo», iperfecto! Pero, ¿qué significa que Alejandro sea hijo de Filipo? Significa que Filipo es la causa eficiente de Alejandro, Filipo debió preceder a Alejandro, y este seguirse necesariamente de él; así este juicio no es asertórico, sino apodíctico. $\mathrm{Si}$, en cambio, significa que Filipo, según nuestras percepciones, fue anterior a Alejandro y este vino después, entonces esto es realmente una mera percepción $\mathrm{y}$, por lo tanto, no es ningún juicio. Así pues, los juicios asertóricos no tienen, consecuentemente, ningún significado.

Así, la Crítica de la Razón no solo ha pasado por alto la parte más importante e imprescindible para la delimitación de la extensión total del terreno del entendimiento, a saber, la investigación del origen, extensión y verdadero significado de sus formas, sino que también ha transmitido [470/412] los errores que se han colado en el uso [de dichas formas del entendimiento] a la lógica, para la determinación de sus formas en sí.

II. La Crítica de la Razón es incompleta en lo que respecta a las preguntas en torno a nuestro conocimiento sintético.

El proceder de la Crítica es el siguiente: I. Explica la diferencia entre juicios analíticos y sintéticos; contra la cual no tengo nada que objetar. II. Establece como un factum indudable de la conciencia que todas las ciencias teoréticas (matemática, ciencias naturales) contienen juicios sintéticos a priori. III. Se plantea la pregunta: ¿Cómo son, en general, posibles los juicios sintéticos a priori? Esta es determinada de forma más exacta mediante las dos siguientes 
preguntas: ¿cómo es posible la matemática pura?, y ¿cómo es posible la ciencia de la naturaleza? A las cuales responde a su modo.

Por «juicios sintéticos a priori de la matemática» Kant no entiende juicios que se refieren a un objeto en general y, en consecuencia, que deban ser válidos a priori para todo objeto determinado (como el primer principio de los juicios analíticos, el principio de contradicción); pues, de hecho, la matemática no contiene juicios de este tipo en la medida en que todos sus propios juicios se refieren a objetos determinados. Por tales [471/413] juicios [sintéticos a priori de la matemática] entiende él aquellos que se refieren a objetos determinados de la matemática pura $\mathrm{y}$, en consecuencia, deben ser válidos a priori para todos los objetos empíricos que han de ser subsumibles bajo ellos. La repuesta a la pregunta «¿cómo, en general, son posibles los juicios sintéticos a priori?» es: «mediante construcción», es decir, debemos atribuir a los sujetos (objetos de la matemática) los predicados determinados mediante tales juicios ya que no pueden ser expuestos como objetos reales si no lo son con estos predicados. Sin embargo, así, la universalidad a priori de este tipo de juicios, en referencia a objetos empíricos que han de ser subsumibles bajo ellos, es explicada solo como una consecuencia de la necesidad intrínseca de los juicios que hacen referencia a los objetos puros de la matemática, - pero la necesidad en sí de tales juicios no es explicada.

Pero, ¿acaso no hay una enorme diferencia entre el tipo de explicación de la posibilidad de los juicios analíticos y sintéticos a priori? A la pregunta: «¿por qué no puedo unir a este o aquel objeto determinado ningún predicado que contradiga a su concepto?», la respuesta es: «porque no puedo unir a ningún objeto en general predicados que contradigan su concepto». Así, derivo esa proposición particular inmediatamente a partir del principio general, el cual pienso, sin referencia a un objeto real, mediante meros símbolos que se refieren a un objeto del pensar en general. Por el contrario, a la pregunta: «ipor qué pienso como posible una [472/414] figura rectilínea delimitada mediante tres o más líneas, pero no mediante dos?» La respuesta no es: «porque no puedo pensar un objeto en general de otro modo», ni siquiera: «porque no puedo pensar ningún objeto real en general de otro modo», sino solo "porque no puedo pensar ese objeto de otra manera». Por tanto, la Crítica de la Razón, antes de preguntarse ¿cómo son posibles los juicios sintéticos en la matemática?, incluso antes de la pregunta: ¿cómo son posibles, en general, los juicios sintéticos a priori?, debería haber respondido 
a la pregunta: ¿cómo son posibles los juicios sintéticos como juicios en sí, sin referencia a los objetos empíricos que han de ser subsumidos bajo ellos, y en relación a los cuales son a priori? Entiendo perfectamente cómo la proposición matemática que he introducido antes, en relación a un objeto de la matemática pura, debe ser, bajo la presuposición de su necesidad en sí, válida para todo objeto empírico que ha de ser subsumible bajo la misma. Pero, ¿cómo es comprensible esta necesidad en sí a partir de un principio general? Una proposición tal es, en efecto, en relación a los objetos empíricos por subsumir, a priori en sí, pero, en tanto que su necesidad no es explicable a partir de un principio general, ¿es equiparable a una proposición $a$ posteriori? Pienso este objeto determinado de este determinado modo, ¿por [473/415] qué? Porque en la construcción no puede ser expuesto de otra forma.

La pregunta: ¿cómo son posibles los juicios sintéticos a priori en la ciencia de la naturaleza?, tiene -como se aclara a partir de la respuesta- un significado diferente, tanto de la pregunta: ¿cómo son posibles los juicios analíticos?, como de la pregunta: ¿cómo son posibles los juicios sintéticos a priori en la matemática? [La segunda pregunta] significa: «¿cómo podemos predicar de modo necesario algo de todos los objetos determinados a priori, [es decir,] antes del conocimiento de sus determinaciones particulares?» A ello se responde: «antes del conocimiento de sus determinaciones particulares, debemos predicar de objetos determinados aquello que debemos predicar de un objeto en general». La [última pregunta] significa: «¿cómo podemos predicar de modo necesario predicados de objetos determinados (predicados dados mediante los mismos), como si no fuesen determinados mediante esos determinados objetos sino mediante la forma del conocimiento en relación a un objeto en general?» A la que la respuesta es: «mediante construcción». Sin embargo, como se ha mostrado, esta respuesta es insatisfactoria.

Por contra, la pregunta: ¿cómo son posibles los juicios sintéticos a priori en la ciencia de la naturaleza? no significa, como la primera, «¿cómo podemos predicar [474/416] de todos los objetos empíricos algo necesario?» (ya que, de hecho, no predicamos sintéticamente de todos los objetos empíricos de forma indiferente), tampoco significa, como la segunda pregunta, «¿cómo podemos predicar algo sintético a priori de objetos determinados como tal?» (ya que la respuesta a ella, la posibilidad de la 
experiencia, no sería satisfactoria en la medida en que así no es determinado ningún objeto empírico al que hagan referencia los juicios sintéticos a priori). La pregunta es más bien: «¿Qué fundamento tenemos para usar juicios sintéticos a priori en relación a objetos empíricos en general sin determinar a cuáles?» A la que la respuesta es: «el fundamento debe ser la posibilidad de la experiencia, ya que los objetos empíricos solo pueden ser objetos de la experiencia posible mediante estos juicios». Cuando realizo el juicio «a es causa de b», pienso los objetos dados «a» y «b» en la relación de causa y efecto no por el hecho de que deba pensar solo esos objetos en dicha relación, sino por el hecho de que así debo pensar todo objeto en general. Algo que no sería verdadero en la medida en que puedo pensar «a»y «c» sin hacer referencia a esta relación. También: Tampoco me es dada esta relación mediante estos objetos, pues de otro modo no podría predicar de ellos esta relación de una forma necesaria, sino porque todos los objetos [475/417] empíricos pueden hacer posible la experiencia solo bajo la presuposición de esa relación entre ellos.

No veo ninguna contradicción en «una figura trazada con dos líneas»; tampoco puedo determinar a priori si puede ser construida una figura tal, sino que debo intentar primero su construcción y entonces ver que es imposible. Por contra, cuando pienso, por ejemplo, «el fuego es causa del calentamiento», lo hago no porque encierre una contradicción que «el fuego no sea causa del calentamiento», tampoco por el hecho de que «fuego»y «calentamiento» sean percibidos inmediatamente por mí en esa relación (en la medida en que la percepción no puede dar una necesidad determinada mediante esta relación), sino porque sin esa relación yo percibiría de forma totalmente contingente la consecuencia del calentamiento por el fuego y no podría experimentarlo según leyes universales.

Así, la Crítica de la Razón confunde entre sí preguntas con un significado totalmente diferente y expresa las mismas de un modo similar. Sus respuestas deben, por lo tanto, ser consideradas insuficientes en relación a algunas de ellas.

III. La Crítica de la Razón no ha indicado ningún criterio del pensar real.

[476/418] La Crítica de la Razón determina el pensar o conocer real mediante el hecho de que a la unidad de la forma le sea dada una multiplicidad 
como materia en la intuición en general. Pero no da ningún criterio a priori mediante el cual se pudiese saber si una pluralidad dada puede ser pensada en una unidad de la forma en general, y menos aún uno mediante el cual se pudiese saber en qué unidad puede ser pensada. No todas las multiplicidades dadas pueden ser pensadas en cualquier unidad objetiva en general. «Figura rectilínea» y «tres (o más) líneas» puede ser pensado bajo la forma de la afirmación (como posible); «figura» y «dos líneas» bajo la forma de la negación (como imposible). Por contra, «figura» y «virtud» no pueden ser pensadas ni en la forma de la afirmación ni en la de la negación. Ni se puede decir «una figura es virtuosa», ni «una figura no es virtuosa». Por lo tanto, debe ser hallado un criterio a priori en la pluralidad dada al pensar, mediante el cual no solo se pueda conocer si esa pluralidad puede ser pensada en alguna unidad objetiva en general, sino también en qué unidad.

Sin embargo, el motivo por el que la Crítica de la Razón no ha intentado encontrar tal criterio del pensar real y ni tan siquiera ha tratado [477/419] su indispensabilidad, reside meramente en que separa totalmente la lógica general de la filosofía transcendental, entendiendo la primera como consistente por sí misma y fundamento de la segunda. Pero, como ya he mostrado, la lógica misma debe estar sujeta a una crítica de la facultad del conocimiento si sus formas tienen que tener un significado y algún tipo de uso; cómo sea esto posible deberá ser expuesto de forma más detallada a continuación.

IV. La Crítica de la Razón ha planteado la pregunta, quid juris?, es decir, «¿con qué derecho podemos utilizar conceptos y juicios puros a priori en relación a objetos empíricos?»; y ha respondido a esta pregunta mostrando que debemos usar estos como condiciones de la posibilidad de la experiencia en general. Sin embargo, aún queda pendiente la pregunta quid facti?, es decir, si realmente [wirklich] usamos estos conceptos y principios a priori en relación a objetos empíricos o no. Este uso no puede ser considerado como un hecho indudable de la conciencia, ya que esta conciencia puede apoyarse en una ilusión psicológicamente explicable.

Además, ya que estos conceptos y principios tienen su realidad meramente como condiciones de posibilidad de la experiencia en general, queda aún pendiente la siguiente pregunta: «¿cómo se relacionan con objetos determinados [478/420] de la experiencia?» Del hecho de que los objetos en 
general deban ser pensados en la relación, por ejemplo, de causa y efecto si una experiencia en general debe ser posible, no se comprende por qué, por ejemplo, justamente «fuego» y «calor» tienen que estar en esa relación.

La Crítica de la Razón responde a esta pregunta diciendo: es determinado inmediatamente mediante la facultad de juzgar. Pero el juicio puede consistir, según mi opinión, solo en la comparación de un objeto con una regla mediante la cual este es determinado y no en la comparación del objeto con una regla mediante la cual es posible un objeto de la experiencia en general. $\mathrm{Si}$, por ejemplo, hago el juicio «este plato es redondo», comparo «el plato» con una regla pensada a priori en virtud de la cual «figura redonda» es determinada como objeto, llegando así, mediante esa comparación, a ser una nota de «el plato». Por el contrario, la relación de la causalidad no es ninguna nota de los objetos empíricos particulares a los que se refiere, sino meramente la condición de posibilidad de una experiencia o de un enlace necesario entre objetos empíricos en general.

Juzgar no es, de ninguna manera, una función de una facultad particular, sino meramente [479/421] un jucio sobre la identidad entre las notas del objeto y los conceptos determinados. Una identidad tal no es posible de encontrar en los juicios de experiencia.

V. La Crítica de la Razón no ha expuesto suficientemente las representaciones necesarias en relación a objetos sensibles, [es decir,] tiempo y espacio.

Ella ha mostrado que el tiempo y el espacio no son representaciones empíricas (no son notas de objetos empíricos). Ellos deben, por lo tanto, ser formas de la sensibilidad determinadas a priori en el ánimo [Gemüthe]. Pero así aún no queda probado que estas sean formas originarias; ellas podrían ser productos de alguna función de la facultad del conocimiento y ser tomadas como originarias mediante una ilusión de la imaginación. Si se pudiese mostrar cómo es posible que esto suceda de acuerdo con las leyes de la psicología que no son conocidas, esto sería más adecuado al método que se usa en una ciencia para explicar, fundamentalmente, el origen de tales representaciones, en lugar de tomarlas como originarias como hace una filosofía descuidada.

Ahora bien, tiempo y espacio pueden ser formas o condiciones a priori de la percepción sensible de una diferencia entre [480/422] objetos 
empíricos. Por lo tanto, estos se refieren originariamente solo a objetos que son representados como diferentes unos de otros mediante notas internas y no a aquellos que no permiten ninguna diferenciación. Un río, por ejemplo, cuyas partes son iguales, no es representado originariamente en el espacio. Esto sucede solo mediante la relación de sus partes homogéneas a las partes adyacentes heterogéneas de los objetos que están en la orilla. Pero mediante una ilusión de la imaginación estamos inducidos a creer que el río en sí es representable en el espacio y más cosas parecidas. Ya que nos hemos acostumbrado desde siempre a este tipo de relaciones, no es ninguna sorpresa si pensamos no poder prescindir de la representación del espacio. Y lo mismo puede ser mostrado con el tiempo.

VI. La Crítica de la Razón obtiene subrepticiamente toda la doctrina de las ideas, en la medida en que las derivas de la naturaleza de la Razón, ya que, como es fácil mostrar, estas tienen su origen en la naturaleza de la imaginación.

La Crítica de la Razón deduce las ideas a partir de las formas de la Razón. Ella define la Razón como la facultad de los principios. De acuerdo con ello, la Razón aspira a la totalidad del uso del entendimiento (que está restringido meramente a la experiencia). Tales ideas [481/423] son, por lo tanto, representaciones de esa totalidad según sus diversos momentos. Pero tal doctrina en su totalidad es capciosa. No es la Razón, sino la imaginación, la que aspira a la totalidad del uso del entendimiento. La Razón no es la facultad de los principios, sino, como se ha explicado tradicionalmente, la facultad de enjuiciar de forma mediata según principios. Cómo de larga es la serie de los juicios que deben ser unidos es algo indeterminado por la naturaleza de la Razón. Del mismo modo, la Razón tampoco determina la absoluta necesidad de los principios. «Deducir» no significa otra cosa que inferir (a partir de principios aceptados hipotéticamente). La Razón determina meramente la forma; sin embargo, la realidad (verdad material) de los principios mismos es determinada mediante la sensibilidad y el entendimiento.

En cambio, sí que es una función de la imaginación productiva (poética [dichterisch]) la de ampliar representaciones empíricas más allá de los límites de la experiencia y representar de forma absoluta aquello que está delimitado mediante las condiciones de la experiencia. De este tipo son las ficciones de lo ideal, que no pueden ser halladas en ninguna experiencia 
posible. Este impulso hacia la totalidad en nuestro conocimiento está fundado en el impulso hacia la suma perfección. [482/424] Ahora bien, la representación de esta totalidad como objeto es contraria a dicho impulso y tiene como base nuestra limitación.

Así pues, todo aquello que la Crítica de la Razón quiere haber dado por fundado en las "ideas de la razón" (religión, moral) está fundamentado realmente en el impulso innato en nosotros hacia la suprema perfección. Pero este no es un principio formal de la Razón, algo propio de ella, sino que es común a todas las facultades.

Qué se ha ganado o perdido para la religión y la moral mediante un modo u otro de entender estas ideas, o si quizá ambos modos de entenderlas sean el mismo, no es aquí lugar para discutirlo. De lo que se ha dicho, puede observarse claramente cómo la Crítica de la Razón busca enriquecer la lógica y la filosofía trascendental a expensas de la psicología y cómo el fundamento último de mi escepticismo tiene como base el descubrimiento del incorrecto método en el que se apoya tanto el dogmatismo como el criticismo.

\section{Carta Séptima}

[483/425]

«iBien! -le oigo exclamar- ${ }^{11}$ usted no quiere admitir que el escepticismo consista, entre otras cosas, en la afirmación de que la Razón no pueda decir nada sobre los límites de nuestro conocimiento, sino que usted mantiene que la Razón, después de realizar una crítica [de la misma], puede determinar dichos límites y los debe determinar antes del uso del conocimiento. Usted toma como infundadas mis observaciones escépticas contra la crítica kantiana. Me concede la mayoría de mis observaciones contra la doctrina fundacional del señor Reinhold, pero encuentra usted mismo tal número de carencias y lagunas considerables en la Crítica de la Razón que cree estar autorizado a intentar su propia crítica de la facultad del conocimiento $\mathrm{y}$, con ella, a prescribir los límites tanto del escepticismo como del dogmatismo. ¿Cómo comienza usted? ¿Qué principios pone como fundamento de su crítica? ¿Qué límites del conocimiento humano quiere fijar como imposibles de sobrepasar? ¿Y qué tipo de indudables resultados quiere obtener?»

\footnotetext{
${ }^{11}$ Filaletes (Maimon) se refiere aquí a su interlocutor ficticio Aenesidemus (Schulze).
} 
Poder dar una respuesta satisfactoria a estas cuestiones es la intención de esta carta. Ya que, sin embargo, todo esto [484/426] lo he tratado detalladamente en la presente obra, ${ }^{12}$ me conformaré con una breve visión de conjunto.

En mi Lógica comienzo con la afirmación de que la lógica general debe ser separada de la trascendental y, no obstante, debe ser tratada siempre con vistas a aquella. Los principios y las formas lógicas presuponen principios trascendentales sin los cuales ellas no tienen ningún significado. No se les puede atribuir ningún otro significado que no sea aquel determinado mediante tales principios trascendentales.

El objeto de la lógica es, siguiendo lo dicho, una «X» indeterminada mediante sus notas internas, pero, sin embargo, determinable mediante las condiciones del pensar un objeto real en general. No la «X» de una expresión algebraica, la cual puede ser sustituida como objeto mediante cualquier cantidad, sino la «X» de una ecuación, la cual solo se puede sustituir mediante la cantidad determinable mediante las condiciones del ejercicio.

Con esto establecido, paso ahora a determinar los principios y las formas lógicas. Los principios lógicos son el principio de contradicción y el principio de identidad, inmediatamente derivado de aquel. El principio de contradicción ya presupone un objeto pensado, [485/427] es decir, una unión [Verbindung] de una multiplicidad en una unidad de la conciencia [Einheit des Bewußtseyn]. La contradicción solo se da inmediatamente entre formas contrapuestas. «A contradice no-a» no tiene, en lo que respecta a la lógica, ningún significado. Si ha de tenerlo, entonces debe decirse: «a es necesario», «a es efectivo» o «a es posible» contradice «a no es necesario», «a no es efectivo», «a no es posible»; o también, «a es b» contradice «a no es b», es decir, una unión según una forma dada contradice una unión (en relación a la misma cosa unida) según una forma contrapuesta. Por contra, aquello que no contiene ninguna unión según una forma no puede ser pensado en contradicción consigo mismo.

Ahora paso a la determinación de las formas según la división de la Crítica de la Razón.

\footnotetext{
${ }^{12}$ Como se ha señalado en la introducción, la obra a la que se refiere Maimon es el Ensayo sobre una nueva lógica o teoría del pensar, en cuyo apéndice están contenidas las cartas aquí traducidas.
} 
I. Hago notar que las formas de cantidad -universalidad, particularidad e individualidad- no son usadas en juicios originarios ([aquellos] no derivados de otros), sino solo en juicios producidos mediante silogismos, los cuales (al ser silogismos abreviados) son tomados erróneamente por juicios originarios. Pero, ya que esto ya lo he mostrado y explicado mediante ejemplos en la carta precedente, basta referirme a ellos, evitando así repetirme.

[486/428] II. Las formas de cualidad -afirmación, negación e indeterminación (infinitud)- sí que tienen un fundamento. «Afirmación» significa una unión real [Realverbindung] entre sujeto y predicado, según el principio de determinabilidad, que más adelante deberá ser definido. «Negación» significa una separación que tiene su fundamento en la unión ya pensada del sujeto con un predicado opuesto al que ya está dado. "Infinitud» significa una unión meramente subjetiva (mediante la identidad del sujeto) mediante la cual se niega la posibilidad tanto de una unión objetiva como la separación [de la misma].

III. Según la relación, los juicios son divididos en juicios categóricos, hipotéticos y disyuntivos. Sin embargo, hago notar que la forma hipotética no es una forma especial de los juicios, sino la forma general de los silogismos. El juicio, por ejemplo, «si a es b, entonces es c» (si un triángulo es equilátero, entonces es isógono) es equivalente al juicio: «un a que sea $b$, entonces es $\mathrm{c}$ » (un triángulo equilátero es isógono), y se diferencian solo según la forma exterior o la expresión.

La forma más general del silogismo (la de la primera figura a la cual se puede reducir el resto) es «si a es b y c es a, entonces c es también b». Aquí tenemos, por tanto, la [487/429] auténtica forma hipotética. De este modo, un silogismo es un juicio hipotético, cuyo antecedente se compone de dos juicios -los cuales tienen un elemento común- y cuyo consecuente es la conclusión.

IV. Según la modalidad, los juicios son divididos en juicios apodícticos, asertóricos y problemáticos. Sin embargo, ya que yo pongo en duda el uso del entendimiento en la experiencia -por motivos que más adelante mostraré- no puedo aceptar los juicios asertóricos. La matemática, donde se encuentran los juicios propiamente objetivos, solo sabe de juicios apodícticos y problemáticos, y nada de asertóricos. 
Además, la lógica ha carecido hasta ahora de la unidad sistemática que toda ciencia requiere; se ha prestado más atención a la forma externa que a la esencia interna de sus partes constituyentes. Se la dividió comúnmente en las supuestas "tres operaciones del entendimiento": en la doctrina de los conceptos, de los juicios y de los silogismos; sus partes fueron ordenadas sucesivamente y no asidas en relación mutua.

He intentado remediar esta carencia mostrando que las supuestas "tres operaciones del entendimiento", según su esencia, constituyen una y solo una [488/430] operación del pensar y, solo en cierta consideración, difieren entre sí. Por tanto, muestro en cada una de estas partes su posible reducción a las otras. Y hasta aquí en lo que se refiere a la lógica general.

Como fundamento a mi crítica de la facultad del conocimiento pongo, en primer lugar, un factum de la conciencia: «tenemos juicios sintéticos, necesarios y universales, que hacen referencia a priori a objetos determinados». Por tanto, planteo la pregunta: ya que esos juicios son determinados solo mediante los objetos, ¿cómo pueden referirse a priori a los mismos? Que, por ejemplo, «la línea recta es la más corta entre dos puntos», no lo puedo saber antes de la construcción de la línea recta. De la misma manera, tampoco antes de la experiencia efectiva puedo saber que «los rayos del sol derriten el hielo». En ambos casos solo puedo decir: «así es en mi percepción», pero no «así tiene que ser». Cada una de las líneas rectas que construiré en el futuro será la más corta entre dos puntos; cada vez que perciba los rayos del sol en su debida dirección y distancia respecto al hielo, percibiré también que este se derrite. Una cosa totalmente diferente sucede en los juicios analiticos, los cuales, ya que su principio (el de contradicción) se refiere [489/431] a un objeto indeterminado en general, no son determinados solo mediante objetos determinados.

Así pues, la tarea es: se debe encontrar un principio sintético (un primer principio [Grundsatz]) que se refiere a un objeto en general, como [hace] el [principio] analítico, y a partir del cual se puedan derivar todos los juicios sintéticos que se refieren a objetos determinados.

La Crítica de la Razón responde: este principio es, en relación a los juicios sintéticos de la matemática, la posibilidad de una construcción y, en relación a los juicios sintéticos de la experiencia, la posibilidad de la experiencia en general. Pero, ¿acaso no llama la atención la diferencia de estas respuestas? La posibilidad de una construcción es, sin duda, un 
principio al cual se pueden reducir [zurückführen] todas las proposiciones de la matemática. Pienso la «línea recta» como «la más corta entre dos puntos» porque solo aquel pensar que permite tal construcción tiene realidad: así, «línea recta» no puede ser construida de otra forma a como «línea más corta», etc.

Sin embargo, ¿cómo puedo derivar del principio «todo lo que sucede, sucede según la ley de la causalidad» la proposición determinada mediante objetos dados «los rayos del sol derriten necesariamente el hielo»? A partir de este principio [490/432] se sigue solo que los objetos de la experiencia en general deben ser pensados recíprocamente en una relación causal y, en ningún caso, que precisamente esos objetos deben estar en dicha relación.

En mi opinión, la respuesta a esta pregunta es errónea: conocemos solo juicios sintéticos en relación a los objetos de una posible experiencia en general y ningún juicio sintético que se refiera a objetos determinados de la experiencia efectiva. Que creemos tener tales juicios se funda, según la presuposición de los dogmáticos, en algo externo a la facultad del conocimiento. Sin embargo, según mi desarrollo filosófico personal de la perspectiva humeana, esto se basa en algo meramente subjetivo (el hábito); es decir, yo pongo en duda el factum de que tengamos juicios sintéticos (necesarios objetivamente) en relación con objetos determinados de la experiencia, pues no comprendemos la posibilidad según la cual podríamos tenerlos, ya que su posibilidad es entendida meramente como una unión subjetiva según leyes psicológicas. Ahora llego a lo más importante en mi crítica de la facultad del conocimiento, a saber, a la determinación de un criterio de pensar real a priori.

Ya he dado cuenta en mi carta precedente de que la Crítica de la Razón pone a priori como fundamento de todo pensar real la posible [491/433] exposición (posible construcción, posible experiencia); pero ella no ha dado ninguna nota [es decir, ninguna indicación] según la cual se pueda conocer $a$ priori si un objeto dado puede ser expuesto o no. Si la multiplicidad pensanda en una unidad de la conciencia puede exponerse o no como objeto, no puede ser determinado a priori antes de la exposición efectiva sino solo mediante ella. El objeto puede ser conocido, por tanto, meramente en vista de su uso empírico, pero no en sí a priori. Que, por ejemplo, «un triángulo» es posible, lo sé solo mediante la construcción efectiva del triángulo. Ahora bien, esta construcción es a priori respecto al uso empírico que se debe hacer de la 
misma, es decir: antes de encontrar un objeto empírico triangular en la experiencia ya sé, de antemano, que es posible. Pero la posibilidad del triángulo en sí la reconozco solo mediante su construcción efectiva.

Para poder hallar un criterio tal, he tenido que investigar la naturaleza del «pensar real» con mayor exactitud a como se ha realizado hasta ahora. Con ello, lo he diferenciado tanto del «pensar meramente formal» como del «pensar arbitrario». He encontrado que hay tres tipos de relaciones en las que la multiplicidad puede estar unificada mediante el pensar respecto a la conciencia en general.

[492/434] 1) Sujeto y predicado pueden estar en una relación tal respecto a la conciencia en general que ninguno de los dos pueda ser sin el otro un objeto de la conciencia en general. De este tipo son todos los conceptos de relación definibles recíprocamente: por ejemplo, «causa y efecto»; «causa» como concepto no puede ser pensado de un determinado modo sin «efecto», y «efecto» $\sin$ «causa». «Causa» es aquello que produce un «efecto» $\mathrm{y}$ «efecto» aquello que es producido mediante una «causa». Por lo tanto, la proposición que expresa la unión de «causa y efecto» es un juicio analítico-sintético.

«Causa»y «efecto» no son la misma cosa de forma idéntica y, sin embargo, no pueden ser pensados de forma determinada por separado. Esta proposición es meramente formal; sin embargo, expresa una posible relación entre objetos, pero deja indeterminados los objetos mismos.

2) Estos [, sujeto y preciado,] también pueden estar en una relación en la cual cada uno sea sin el otro (fuera de la unión) un objeto de la conciencia. De este tipo son todas las uniones arbitrarias, por ejemplo, «una piedra que atrae el oro», y todas las del mismo tipo. Sujeto y predicado pueden darse en la conciencia sin el otro; el pensar de los mismos en una unidad de la conciencia no tiene, pues, ningún fundamento real, y es meramente arbitrario. El pensar formal es una unidad determinada sin pluralidad. El [493/435] arbitrario es al revés, una pluralidad determinada sin unidad. Ambos no pueden, por lo tanto, determinar un objeto real.

3) Estos pueden estar en una relación en la cual el objeto [o sujeto], sin el predicado, pueda ser un objeto de la conciencia, pero no este sin aquel. De este tipo son todos los objetos reales determinados a priori (de la matemática); por ejemplo, «línea recta», «ángulo recto», y todos los del 
mismo tipo. El «ser rectilíneo» no puede darse en la conciencia sin «algo» que sea «recto», el «ser rectangular» $\sin$ «algo» que sea «rectangular». Por contra, este «algo» es un objeto determinado de la conciencia (una línea, un ángulo) aún sin ser «rectilíneo»o «rectangular».

Establezco, pues, el siguiente principio como criterio del pensar real a priori:

La multiplicidad dada debe estar en una relación entre sí en la que el sujeto también en sí, sin el predicado, pueda ser objeto de una conciencia en general pero no este sin aquel.

Mediante este criterio he podido dar el significado adecuado de los denominados «juicios infinitos» en la lógica, que hasta el momento solo representaban un juego de símbolos (en la medida en que se creía haberlos determinado de forma suficiente y haberlos diferenciado de los juicios negativos solo mediante el hecho de desplazar la negación de la cópula al predicado).

[494/436] «Juicios infinitos» son, según mi opinión, juicios negativos cuyo fundamento, sin embargo, no consiste en que un predicado opuesto al ya dado esté contenido ya en el sujeto (como en los denominados «juicios negativos»), sino en el hecho de que ni el predicado [dado], ni su contrario, puedan ofrecer una posible determinación real del sujeto ya que ambos pueden darse en la conciencia sin el otro. «Un círculo no es cuadrangular» es una proposición negativa; el [predicado dado] «ser cuadrangular» se contrapone a la determinación ya contenida en el «círculo». Por contra, la proposición: «un círculo no es dulce», es una proposición infinita, en la medida en que tanto «dulce» como «amargo» no son una posible determinación del «círculo». Sin tal piedra de toque, los señores filósofos tienen que abandonar sus ganas de combinar conceptos de todo tipo y darles realidad objetiva (bajo el pretexto de que no se contradicen entre sí). Ellos hablan de «conceptos arbitrarios» sin determinar en qué consiste tal arbitrariedad. De aquí se sigue que todos los objetos empíricos en los cuales no sea percibida la relación exigida entre sujeto y predicado para la determinación de un objeto real puedan ser pensados como objetos reales solo bajo la presuposición de tal relación [de determinabilidad], pero no conocidos como tales (ya que tal relación no es comprensible). 
[495/437] La Crítica de la Razón ha diferenciado solo parcialmente el conocer del mero pensar; a saber, el mero pensar es una mera forma relacionada con un objeto indeterminado en general sin materia dada. Esto, sin duda, tiene su razón de ser [Richtigkeit]. Pero yo encuentro otro modo del mero pensar que es justamente contrapuesto a este anterior, a saber, el pensar como objeto una materia dada mediante una forma meramente lógica del conocer (la relación pensable y exigida para la realidad objetiva).

De acuerdo con esto, [el concepto de] «oro» como «metal amarillo» y (por lo que sabemos hasta el momento) «más pesado» es tan poco un objeto real como lo es «el metal verde más pesado»; dado que, sin embargo, encontramos en el tiempo y en el espacio unidas las notas de «oro» y no las notas del otro metal, creemos tener derecho a presuponer, a pesar de todo, tal relación mentada, aunque no la veamos, en el oro, pero no en el otro metal, y pensar el oro como un objeto real. Esta exposición me parece tanto bien fundamentada en sí, como extraordinariamente fructífera para la ciencia. ¡Pero otros podrían pensar de otra forma!

Así, pongo en duda el uso en la experiencia de las categorías por un doble motivo. En primer lugar, por la ya mencionada explicación subjetiva de Hume de ese supuesto uso. Luego, por la carencia del fundamento exigido para tal uso [de las categorías], a saber, [la carencia de] la comprensión de la relación de determinabilidad en los objetos empíricos (que el sujeto pueda ser objeto de la conciencia como lo determinable en sí [496/438] y que el predicado, [pueda ser objeto de la conciencia] no en sí, sino como determinación de aquel).

Las categorías, en mi opinión, no están determinada para su uso en la experiencia, sino para su uso en los objetos determinados a priori de la matemática, y de este modo las he expuesto en esta obra.

Aquí tiene usted un pequeño esbozo de todo mi sistema escéptico, el cual presento a su consideración y a la de todo librepensador. Con todos los correspondientes respetos a un librepensador de su talante. 


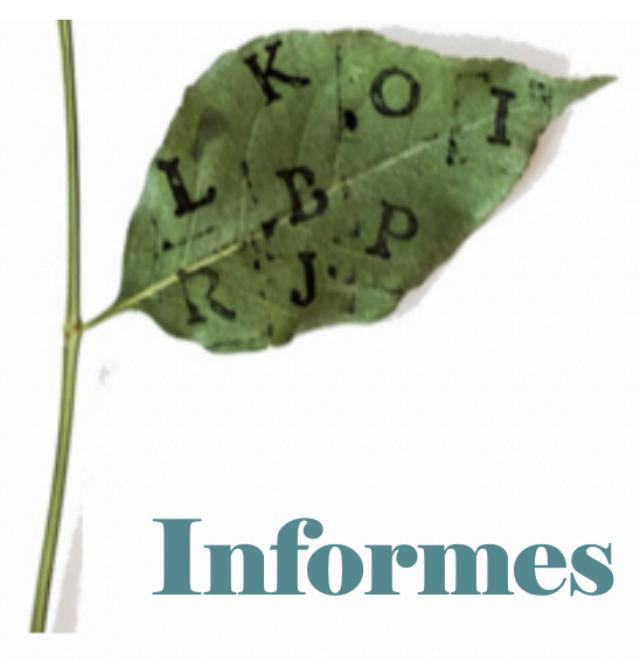




\title{
Informe del IV Congreso Internacional de la SEKLE
}

\author{
ALEJANDRA BAEHR \\ LUCIANA MARTÍNEZ ${ }^{1}$
}

Durante los días 15 a 19 de septiembre de 2018, se llevó a cabo en la ciudad de Valencia el IV Congreso internacional de la Sociedad de Estudios Kantianos en Lengua Española (SEKLE). Los encuentros se realizaron en el edificio de la Facultad de Filosofía y Ciencias de la Educación de la Universitat de València. A lo largo de las cinco jornadas, se discutieron diferentes aspectos de la filosofía de Kant y los participantes tuvieron la oportunidad de visitar algunos sitios de interés cultural e histórico en una ciudad en verdad acogedora.

El lunes, el acto de inauguración estuvo a cargo de las autoridades institucionales y organizadoras del congreso. Tuvieron la palabra la rectora de la Universidad y la decana de la Facultad, las Dras. María Vicenta Mestre y María Rosa Bo respectivamente, así como el director de la SEKLE, el Dr. Jacinto Rivera de Rosales, y el coordinador del congreso, el Dr. Pedro Jesús Teruel. La conferencia inaugural de la profesora Adela Cortina trató sobre "Razón crítica y compromiso cosmopolita". Luego de ello, hubo seis conferencias semiplenarias, presentadas por Gustavo Leyva, que disertó sobre las nociones de conocimiento y de acción; Claudia Jáuregui, que abordó algunos aspectos de la causalidad final; Pedro Ribas, que se refirió a la recepción crítica de Herder; Bernd Dörflinger, acerca de las dificultades de la prueba de la demostración de Dios; Constantino Espósito, que habló sobre "Kant y lo imposible"; y, finalmente, Domingo García-Mazà, que presentó el trabajo "El principio de publicidad en Kant: la aportación de la ética al diseño institucional".

Por la tarde se presentaron numerosas e interesantes ponencias. Algunos de los temas tratados en ellas fueron la cuestión de la actualidad de

\footnotetext{
${ }^{1}$ CONICET, Universidad Nacional de Rosario - Universidad de Buenos Aires.
}

Contactos: abaehr@alumnos.uahurtado.cl; luciana.mtnz@gmail.com. 
la Crítica (Cristóbal Garibay, Alejandro Lanchas, Krista Thomason y Marita Rainsborough); las discusiones por parte de o con otros filósofos (Francisco Iracheta, Dieter Hüning, Rogelio Rovira y Catarina Marinelli); así como diversos aspectos de la filosofía crítica teórica (Gonzalo Serrano, Tommaso Morawski, Martín Arias Albisu, Jacinto Rivera de Rosales, Daniel Dal Monte, Sofía Fazio, Maricarmen Pérez Vela, Henny Blomme y Julia Muñoz) y práctica (Alexandra Hurtado, Vojtech Kolomý, Yasutaka Akimoto y Joel Thiago Klein).

La conferencia plenaria del martes 16 estuvo a cargo del profesor Heiner Klemme, quien presentó su trabajo "Vernunft als Verfahren. Über den Zusammenhang von Kritik und Selbsterhaltung bei Kant". Durante la mañana, se presentaron seis conferencias semiplenarias. Cuatro de ellas se refirieron a la filosofía teórica de Kant. El profesor Mario Caimi defendió una interpretación de la deducción de las ideas de la razón a partir de las formas del silogismo. Vicente Durán se ocupó del vínculo entre la Crítica de la razón pura y la filosofía de la historia. Édgar Maraguat analizó la noción de causa final en el desarrollo del tercer conflicto antinómico, y Salvi Turró ofreció un estudio de la filosofía transcendental a partir de la $K r V$ A801/B829. Además, Faustino Oncina se refirió a las relaciones entre Kant y Fichte, y Fernando Moledo disertó sobre los problemas para dar fundamento crítico a la metafísica de la naturaleza y a la metafísica de las costumbres.

Durante la tarde, una vez más, las ponencias tocaron temas heterogéneos. Los organizadores las agruparon en seis categorías: estética transcendental (Josep Clusa, Diana Contreras, Zhouwanyue Yang y Lisa Benossi); ciencia natural (María Xesús Vázquez Lobeiras, Luciana Martínez, Stephen Howard y Fernando Beresñak); teleología (Diana Loyola, Paula Órdenes, Solange de M. Dejeanne y Silvia del Luján di Sanza); autonomía (Christian Hamm, José María Torralba, María Emilia Ferreyro y Luis Placencia); religión (Eduardo Charpenel, Luciano Perulli, Ileana Beade y Roberto Navarrete); y, en último lugar, las discusiones kantianas en el siglo XIX (Eduard Quitián, Sebastián Cabezas, Valerio Rocco y Jorge V. C. da Conceição).

El miércoles 17 se llevó a cabo la tercera jornada del congreso. En esta ocasión la conferencia plenaria estuvo a cargo de Claudio La Rocca, quien habló acerca de nuestra relación con la verdad y el lugar de la razón crítica en el mundo real. Luego, se desarrollaron cinco ponencias 
semiplenarias. Margit Ruffing se refirió a las ideas trascendentales en la Antropologie; Antonio M. López Molina habló acerca de la concepción kantiana de la razón pura y la síntesis trascendental; Sergio Sevilla se refirió al ejercicio de leer a Kant después de Auschwitz; Ana Andaluz habló acerca de la actualidad de la concepción kantiana de la verdad. Por último, Pedro Stepanenko se refirió a la concepción kantiana de objeto trascendental y cosa en sí.

Las ponencias de la tarde se ordenaron según su afinidad temática. En primer lugar, se presentaron varios trabajos acerca de la concepción kantiana de la matemática (Gilberto Castrejón, Rafael Reyna Fortes, Antonio P. Valerga y Elise Frketich). En segundo lugar, se presentaron las contribuciones centradas en la apercepción trascendental (Carsten Olk, Paulo Jesús y Sandra Palermo). En tercer lugar, se presentaron trabajos que analizaron la relación idealismo/realismo (Kwangchul Kim, Héctor Ferreiro, Manuel A. Amado y Jesús G. Fisac). En cuarto lugar, se presentaron las contribuciones que abordaron el tema del sentimiento y la moral (Robinson A. Rodríguez, Ana- Carolina Gutiérrez y Fernando M. Ferreira da S.). En quinto lugar, se presentaron los trabajos que abordaron la recepción de la $\mathrm{KrV}$ durante los siglos XIX-XX (Francisco Arenas-Dolz, David Hereza, María Rodríguez y Giorgia R. Zamora). Finalmente, se presentaron trabajos que se ocuparon de algunos aspectos de la filosofía kantiana concernientes al estatuto de la opinión y el saber (Laura Herrero, Victoria Tenreiro, Josep Olesti y Hardy Neumann).

En la cuarta jornada del congreso, la conferencia plenaria estuvo a cargo de Onora O’Neil, quien analizó la pregunta “¿Qué debemos hacer?”. Más tarde, se desarrollaron diversas conferencias semiplenarias. Tomás Vives Antón estudió la relación entre libertad trascendental y derecho y sus repercusiones penales. Karin de Boer analizó la noción kantiana de ilusión trascendental y el efecto corruptivo de la sensibilidad sobre la metafísica. Alba Jiménez se ocupó de los juicios sintéticos a priori como protoforma de las flexiones del imperativo categórico. Julio del Valle se refirió a Kant y la mirada hacia las artes. Maximiliano Hernández Marcos habló acerca de Kant y el nuevo realismo. Por último, Catalina González estudió un antecedente al concepto kantiano de crítica en Crousaz.

Por la tarde, se presentaron contribuciones dedicadas distinción fenómeno/noúmeno (Sophie Grapotte, Chong-Fuk Lau y Peter Schwind). En 
segundo lugar, se presentaron los trabajos acerca de la Analítica trascendental (Álvaro Peláez, Mónica Carbó y Michele Cardani). En tercer lugar, se presentaron las colaboraciones dedicadas a las reflexiones (Héctor Pérez, Carlos Mendiola, Paolo Grillenzoni y Paola Romero). En cuarto lugar, se llevaron a cabo las ponencias dedicadas a la concepción kantiana del deber (Martin Brecher, Gabriel Rivero y Daniela Alegría). En quinto lugar, se presentaron las ponencias dedicadas a la recepción de la $K r V$ en el $\mathrm{S}$. XX (Iván Campillo, Ruth M. Espinoza, Javier Gracia y Luis Moisés López). Finalmente, se presentaron las contribuciones dedicadas a la concepción kantiana de la Historia (Leonardo R. Duplá, Enzo Solari, Marcos Thisted y Soledad García Ferrer).

El viernes 19 se desarrolló la última jornada del congreso. Lamentablemente, y debido a un fenómeno climático inesperado, algunas de las actividades programadas debieron ser suspendidas. No pudieron presentar sus contribuciones los expositores de ese día. En cambio, la conferencia de cierre, la asamblea de socios de la SEKLE y la ceremonia de entrega del Premio Kant para jóvenes investigadores e investigadoras se desarrollaron en la sede histórica de la Universidad de Valencia. La conferencia de cierre, intitulada "Contemplación", estuvo a cargo del profesor Pablo Oyarzún. En ella, el profesor analizó el significado de ese término en las dos partes de la Crítica de la facultad de juzgar.

Luego, en la ceremonia de entrega del II Premio Kant para jóvenes investigadores e investigadoras en lengua española, se otorgó una distinción honorífica a los profesores Onora O’Neil, Claudio La Rocca y Mario Caimi por su trayectoria en los estudios kantianos. A continuación, se premió a Alejandra Baehr por su trabajo acerca de la relación entre apercepción trascendental y existencia en la segunda edición de la $K r V$. Finalmente, se otorgaron dos menciones, una al trabajo de Ileana Beade acerca de la concepción ilustrada del principio de libertad religiosa; la otra a Rafael Reyna Fortes por su trabajo acerca de la imposibilidad de las hipótesis en matemática. Este premio, en el que participaron veinte candidatos de México, Colombia, Argentina, Chile, España, Italia, Perú, Polonia, Uruguay y Venezuela, contó con la participación, como miembros del jurado, de la profesora Dulce María Granja Castro, el profesor Claudio La Rocca y el profesor Sergio Sevilla. 
Durante los cinco días en los que tuvo lugar el congreso, los temas que se discutieron y las perspectivas de su abordaje fueron variados. Fue notable la participación no solo de investigadores de diversas regiones de España y Latinoamérica (México, Chile, Perú, Argentina, Brasil y Colombia tuvieron sus representantes), sino también de países en los que se hablan otras lenguas, como Alemania, Italia, Portugal, Bélgica, Estados Unidos, Rumania y China. Además de beneficiar a los participantes con este rico intercambio de ideas, el congreso se caracterizó por una organización inobjetable. El programa, variado y extenso, estaba ordenado según estrictos criterios temáticos y los espacios para la realización del evento resultaron confortables y adecuados. Por otra parte, al final de cada jornada, se propusieron actividades culturales interesantes, en las que los detalles habían sido cuidadosamente observados, que pusieron en evidencia la riqueza cultural y la belleza de la ciudad anfitriona. 


\title{
Ata do Simpósio Internacional de Kant a Hegel
}

\author{
AGEMIR BAVARESCO ${ }^{1}$ \\ JAIR TAUCHEN \\ EVANDRO PONTEL
}

Simpósio Internacional de Kant a Hegel (20 e 21 de novembro de 2018)

Pontifícia Universidade Católica do Rio Grande do Sul, (PUCRS),

Porto Alegre, Rio Grande do Sul - Auditório do Prédio 40.

Nos dias 20 e 21 de novembro de 2018 aconteceu na Pontifícia Universidade Católica do Rio Grande do Sul (PUCRS) o Simpósio Internacional de Kant a Hegel. O evento ocorreu no Auditório do Prédio 40, contando com a participação de estudantes, pesquisadores e especialistas interessados no tema da filosofia alemã clássica e suas influências a partir do legado do pensamento de dois pilares da filosofia ocidental, Kant e Hegel. Além de pesquisadores brasileiros de várias universidades federais e demais instituições de ensino, estiveram presentes participantes de seis países (Alemanha, Argentina, Chile, Colômbia, Itália e Peru).

O objetivo geral do Simpósio consistiu em promover o debate entre professores, pesquisadores e estudantes de graduação e pós-graduação em Filosofia sobre o período da filosofia alemã que vai de Kant até Hegel e suas influências. A proposta de participação foi estendida e publicizada por meio de mídias digitais, contando com o importante apoio da Editora $\mathrm{Fi}$, que foi uma parceira fundamental no processo de publicização e de chamada aos interessados, estudantes, professores, pesquisadores em nível de graduação e pós-graduação. A partir desse objetivo a equipe organizadora, composta pelos professores Prof. Dr. Agemir Bavaresco (Pontifícia Universidade Católica do Rio Grande do Sul - PUCRS), pelo Prof. Dr. Thomas Sören Hoffmann (FernUniversität in Hagen), e pelo Prof. Dr. Jair Inácio Tauchen e Prof. Dr. Evandro Pontel (PUCRS) estabeleceram por meio de um processo dialógico uma programação que proporcionasse viabilizar a efetivação do alcance do

\footnotetext{
${ }^{1}$ Pontificia Universidade Católica do Rio Grande do Sul. Contato: abavaresco@pucrs.br.
} 
objetivo geral, propiciando um espaço de encontro, de intercâmbio e de troca de saberes entre os participantes.

O Simpósio foi promovido pela FILORED em parceria com a Escola de Humanidades através do Programa de Pós-graduação em Filosofia, contando com o apoio do CDEA, (Centro de Estudos Europeus e Alemães), CNPq (Conselho Nacional de Desenvolvimento Científico e Tecnológico) e com a parceria estabelecida com a Editora Fi, que desenvolveu o importante e estratégico papel tanto na divulgação do evento quanto no processo de inscrição e submissão dos resumos das comunicações aos participantes, por meio de sua plataforma e das demais mídias que deram visibilidade ao Simpósio Internacional de Kant a Hegel. Como resultado do Simpósio será organizada a publicação de um e-book que comprenderá o conjunto das comunicações apresentadas em formato de artigo, a partir das discussões e temáticas que foram abordadas durante o evento.

A FILORED por se caracterizar enquanto uma rede Germano-Latinoamericana de investigação e doutoramento proporciona o intercâmbio Germano-Latino-americano no âmbito da investigação filosófica sobre a filosofia clássica alemã que vai de Kant a Hegel. Além de reunir e apoiar iniciativas e pesquisas que versem sobre temas filosóficos concernentes à filosofia clássica alemã proporciona espaços de amplo debate e intercâmbio entre pesquisadores e estudantes. $\mathrm{O}$ seu objetivo principal é a promoção da juventude no contexto da investigação orientada internacionalmente, a fim de obter o doutoramento duplo entre duas universidades-membro, que é composta por nove Instituições de Ensino que estão interligadas e atuam conjuntamente na realização dessa rede.

Assim, a FILORED proporciona aos doutorandos dessas nove universidades (Pontificia Universidad Católica de Argentina, Buenos Aires, Pontificia Universidad Católica de Valparaíso - Chile, Institut für Philosophie I der Ruhr-Universität Bochum, Universidade Federal do Ceará - Brasil, Universidad Diego Portales - Chile, Pontifícia Universidade Católica do Perú, Lima, Pontifícia Universidade Católica do Rio Grande do Sul, Porto Alegre, Martin-Luther-Universität Halle-Wittenberg e Universidade Nacional de Colômbia) realizarem investigações em nível doutoral de forma estruturada e supervisionada, por meio de um intenso intercâmbio com professores e doutorandos, a partir de contextos complementares de recepção e de investigação dos clássicos da filosofia alemã. 
A solenidade de abertura do Simpósio ocorreu dia 20 de novembro às $9 \mathrm{~h}$ e foi presidida pelo Prof. Dr. Agemir Bavaresco. Contou com a presença do coordenador da FILORED Prof. Dr. Thomas Sören Hoffmann e do Decano da Escola de Humanidades, Prof. Dr. Draiton Gonzaga de Souza. Após o momento inicial de saudação e boas-vindas aos presentes ambos os professores fizeram uso da palavra e destacaram a importância do evento e a possibilidade de que esse fosse um momento importante de discussão sobre os temas clássicos da filosofia alemã, sua relevância e importância para o pensamento filosófico na atualidade. Na sequência o Prof. Dr. Thomas Sören Hoffmann proferiu a conferência de abertura que versou sobre o tema Darstellung versus Selbstdarstellung des Begriffs: Zum Verhältnis von transzendentaler und spekulativer Logik.

Após a conferência e um breve momento de discussão e diálogo com os ouvintes, a programação prosseguiu por meio das sessões de comunicações que foram organizadas em formato de blocos. Esse formato ordenado por meio da apresentação de três comunicações propiciou que cada um dos participantes tivesse um tempo de 20 minutos para fazer sua explanação. Após as exposições foi previsto um espaço de tempo de 30 minutos para indagações, questionamentos, debates e interlocuções entre os apresentadores e os demais ouvintes.

Em cada um dos dias foi previsto e disposto na agenda do Simpósio dois blocos de comunicações, de tal forma que aconteceu, respectivamente, um bloco no período matutino e o outro no período vespertino. Ao fim do primeiro dia o encerramento das atividades acadêmicas se deu às $17 \mathrm{~h} 30 \mathrm{~m}$ por meio da conferência ministrada pelo Prof. Dr. Hardy Neumann (Pontificia Universidad Catolica de Valparaiso - Chile), que tratou do tema Tras el incondicionado cosmológico: la determinación del concepto de mundo en Kant. Em seguida, os participantes foram recepcionados às $19 \mathrm{~h}$ no Centro de Convivência -Prédio 22 (PUCRS) - para um jantar de confraternização que contou com uma expressiva participação, o qual foi organizado pelo Prof. Dr. Jair Inácio Tauchen.

No segundo dia de Simpósio, às $9 \mathrm{~h}$ aconteceu a mesa-redonda que contou com a participação do Prof. Dr. Agemir Bavaresco, do Prof. Dr. Federico Orsini e da Prof ${ }^{a}$. Dra. Marloren Lopes Miranda, na qual foi abordado o tema Sobre a tradução e lançamento da obra Ciência da Lógica - G. W. Hegel- Na oportunidade o Prof. Dr. Agemir Bavaresco que 
coordenou a tradução da obra do pensador alemão destacou a importância de podermos contar com uma tradução em língua portuguesa de uma obra fundamental no âmbito filosófico. Além disso, reafirmou que a referida traduação desempenha um papel importante por contribuir na recepção da Ciência da Lógica e no desenvolvimento de novas pesquisas em nível de Brasil. Em seguida, os professores, Prof. Dr. Federico Orsini e a Prof ${ }^{a}$. Dra. Marloren Lopes Miranda apresentaram um breve relato acerca da experiência como o grupo de pesquisadores procedeu durante o processo de tradução. Esse processo de elaboração da tradução foi realizado através de uma Equipe de Tradução, que operou em uma dinâmica demarcada pelo diálogo e pelo constante aprendizado entre os membros participantes.

$\mathrm{Na}$ sequência, de acordo com o previsto na agenda aconteceu o primeiro bloco de comunicações que culminou com o encerramento das atividades da primeira parte do dia. A partir das $14 \mathrm{~h}$ se desenvolveu o segundo bloco de comunicações que finalizou a sessão das comunicações previstas. A Comissão organizadora foi assessorada pela comissão executiva assim constituída: Adilson Felício Feiler, Eduardo Garcia Lara, Francisco Jozivan Guedes de Lima, Federico Orsini, Isis Hochmann de Freitas, Marloren Lopes Miranda e Olmaro Paulo Mass. Esses membros das comissão executiva estiveram diretamente envolvidos nas atividades desenvolvidas no evento e no desempenho das mediações durante a apresentação das comunicações.

Ao todo foram apresentadas 41 comunicações durante os dois dias em que se desenvolveram as atividades concernentes ao Simpósio, dispostas conforme o que segue [autor(es)/tema]: Agemir Bavaresco; Eduardo Garcia Lara "Teoria da reflexão como alienação em Hegel e Marx"; Adilson Felicio Feiler "A lógica reconciliante de Hegel em torno às categorias kantianas"; Adriana Fernández Vecchi "La sittliche Gesinnung, el modo ético, la identidad política y el Estado en la Filosofía del Derecho de Hegel"; Alexandre S. Barbosa "Ontologia e estatuto do sujeito a partir de Hegel"; Alexandre Teles "O sistema de Schopenhauer em debate com Jacobi e Schelling"; Daniel Peres Santos "Kant on freedom of the will and human dignity: a foundation for the Universal Declaration of Human Rights"; Damián J. Rosanovich "El trabajador del Estado en el Vormärz: una crítica de la teoría hegeliana del funcionariado"; Eduardo Luft "Hegels Dialektik und reductio ad absurdum"; Emerson de Lima Pinto "Hegel e o mundo invertido: ecos de Gadamer sobre a dialética na Filosofia do Direito e na 
História"; Esteban Mizrahi "Dilemas de la representación política en la filosofía del Estado de Hegel”; Francisco Jozivan Guedes de Lima "Com Kant, contra Hegel: possíveis equívocos hegelianos da crítica ao formalismo moral-deontológico kantiano"; Federico Orsini "Existem regras lógicas? Sobre a resposta de Hegel a um desafio do ceticismo pós-kantiano"; Fernando Moledo "El concepto kantiano de la dignidad humana como respuesta al presunto formalismo de la fundamentación crítica de la moral"; Gabriela Nascimento Souza "As diferentes formas do início da ciência filosófica: Hegel e a origem de suas lógicas"; Gregory Gaboardi "O a priori em Kant e em Hegel"; Lelia Edith Profili "El concepto hegeliano de lo absoluto en el Differenzschrift (1801) y el proyecto de una transformación especulativa de la metafísica"; Héctor Ferreiro "El debate en el Juicio de Núremberg sobre el rol de la filosofía clásica alemana en el surgimiento ideológico del nazismo"; Henor Luiz dos Reis Hoffmann "Crítica de Honneth ao modelo construtivista kantiano"; Jacinto Páez "Filosofía histórica y crítica filosófica en el postkantismo"; João Alberto Wohlfart "O lugar filosófico de Hegel no Idealismo alemão"; Konrad Utz "A síntese originária de Kant e a dialética de Hegel"; Lucas Antonio Saran; Danilo Saran Vezzani "Idealismo e realismo: uma crítica hegeliana e russelliana à Bradley"; Luciano Sampaio Gomes Rolim "Os ideais práticos em Kant"; Marcelo Lucas Cesco "O movimento do Absoluto no seu Vir-a-ser. Observações a partir da Ciência da Lógica"; Marco Rampazzo Bazzan "A dimensão teológico-política de Fichte”; Marcos Cesar Paes de Carvalho Filho "Direito, autoconsciência e liberdade na Fundação do Direito Natural de Fichte"; Marloren Lopes Miranda "Kant, Hegel e a Teoria das Cordas: uma estrada para a unificação?"; Maria Alejandra Gutierrez Correa "Consideraciones generales sobre la conciencia estética del concepto de genio de Kant a Hegel"; Matheus Arthur Gadelha Costa "A Consciência Individual e a Lógica do Sacrifício na Fenomenologia do Espírito"; Miguel Alberti "El pensamiento filosófico temprano de Friedrich von Hardenberg (Novalis) y sus derivas posteriores"; Natália Acurcio Cardoso "A situação da arte dentro do processo da consciência em Hegel"; Olmaro Paulo Mass; Evandro Pontel "A condição da obra de arte e a possibilidade de um pensamento crítico ao presente: um diálogo entre Hegel, Adorno e Agamben"; Paulo Roberto Cardoso; Levindo Ramos "Opinião pública e Liberdade no Estado de Direito"; Rafael da Silva Cortes "Cultura e Aufklärung como representações do Sumo Bem no mundo"; Raphael Machado de Castro; Vinícius Guimarães Dias Francisco "De Kant a Hegel: 
legados para a Estética e o século XX"; Rita de Cássia Souza Tabosa Freitas; Antônio Justino de Arruda Neto "O olhar cosmopolita: atualidades da proposta de Paz Perpétua kantiana"; Robinson dos Santos "O ceticismo e seu significado na Introdução à Fenomenologia do Espírito"; Roger Antonio Pérez García "Desinterés, juego e idea estética: la recepción de la estética kantiana en la filosofía de Schopenhauer"; Rosana Pizzatto "Liberdade e intersubjetividade no sistema de Hegel"; Victor Duplancic "Saber absoluto, metafísica e história"; Wagner de Avila Quevedo "O fragmento Juízo e Ser de Hölderlin: a motivação teórica para uma revisão do idealismo".

Após o término desse momento que contemplou o bloco final de apresentação de comunicações ocorreu à mesa redonda de encerramento que contou com a presença e a contritbuição do Prof. Dr. Thadeu Weber (PUCRS); do Prof. Dr. Hector Ferreiro (CONICET - Argentina) e do Prof. Dr. Konrad Utz (UFC), oportunidade em que cada um dos professores discorreu acerca do tema Relevância do pensamento de Kant e Hegel para a filosofia na atualidade, seguido de um momento de debates, de questionamentos e de interlocuções com os demais participantes. Por fim, no momento de encerramento do Simpósio Internacional de Kant a Hegel, o Prof. Dr. Agemir Bavaresco fez uso da palavra reafirmando a satisfação e a ímpar oportunidade de a Pontifícia Universidade Católica do Rio Grande do Sul (PUCRS), por meio da Escola de Humanidades e do Programa de PósGraduação em Filosofia ter sediado esse importante Simpósio Internacional, agradecendo a cada um e a cada uma dos/das participantes que prestigiaram o evento e que o engrandeceram com sua participação. Agradeceu, ainda, a presença do Prof. Dr. Thomas Sören Hoffmann (FernUniversität in Hagen), coordenador da FILORED, e as demais entidades parceiras que tornaram possível a realização do evento. Destacou, por fim, a importância do trabalho colegiado realizado tanto pela Comissão organizadora do evento quanto pela comissão executiva que cooperou de modo a concorrer para o bom desempenho das atividades previstas na agenda do evento.

Após o encerramento oficial do Simpósio Internacional de Kant a Hegel realizou-se a reunião dos Coordenadores da Rede Germano-Latinoamericana de investigação e doutoramento (FILORED), que foi coordenada pelo Prof. Dr. Thomas Sören Hoffmann. Na reunião foram tratados temas de interesse da Rede de investigação. Os assuntos tratados versaram basicamente sobre a possibilidade de inserção de novas Instituições de Ensino Superior 
que tenham curso de Doutorado e tenham uma relevante pesquisa nos temas ligados à filosofia clássica alemã em nível de doutoramento, além das nove Instituições supramencionadas, que já compõem a rede. Outro tema tratado girou em torno à questão da proposta de data e local para a realização do próximo Simpósio Internacional. 


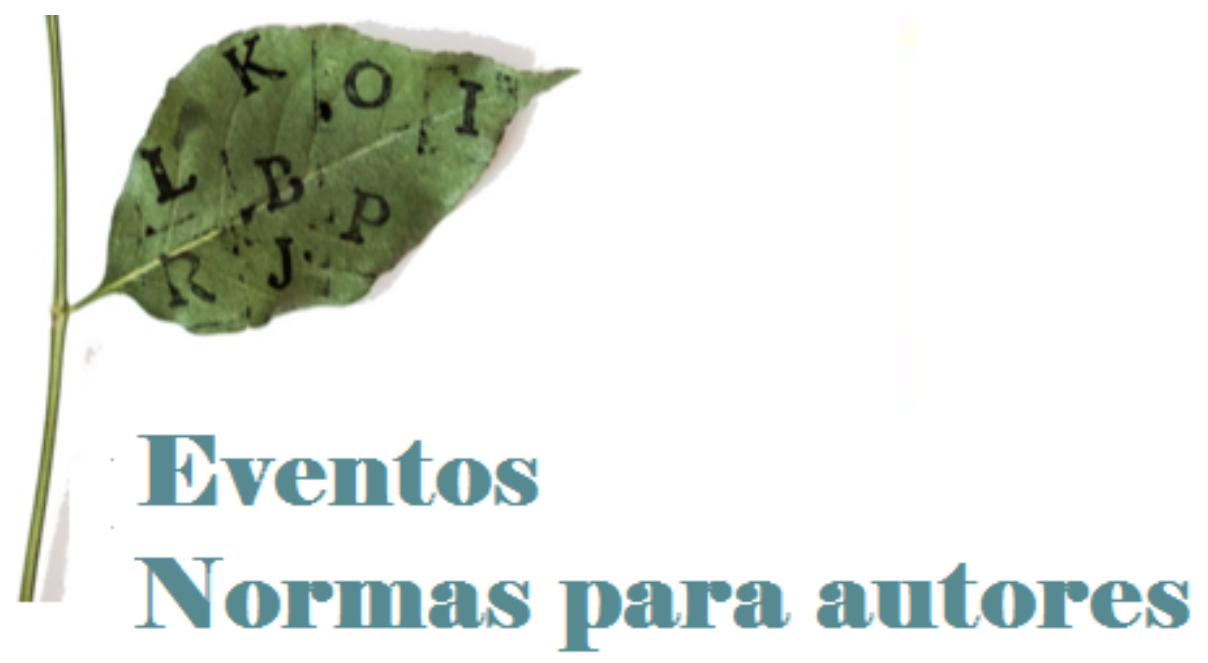




\section{Normas para autores}

La revista publica trabajos redactados en lengua castellana, alemana, inglesa y portuguesa y referidos a cualquiera de los ámbitos relativos a la filosofía kantiana o en los que la presencia de esta tenga una relevancia significativa. Las contribuciones deben ser originales y su extensión no podrá superar los 80.000 caracteres con espacios. Las reseñas no excederán los 16.000 caracteres con espacios.

\section{Encabezamiento}

El texto será precedido por título (Times New Roman, 14 puntos), un resumen (máx. 100 palabras, Times New Roman, 10 puntos) y hasta cinco palabras clave (Times New Roman, 10 puntos, separadas por comas), tanto en la lengua propia del artículo como en inglés (si la lengua empleada en el trabajo es el castellano) o en castellano (si el trabajo está redactado en inglés, alemán o portugués).

\section{Estilo}

\subsection{Cuerpo de texto}

Los textos serán redactados en Times New Roman, 12 puntos, interlineado múltiple 1,15, con espaciado posterior de 6 puntos, con párrafos justificados y sangrados $(1,25 \mathrm{~cm})$ en primera línea siempre que no se trate del párrafo que da comienzo a una sección.

\subsection{Citas}

Las referencias relativas a una cita textual aparecerán en cuerpo de texto, indicando entre paréntesis autor y año seguido de dos puntos y número de página, según el modelo:

...tal y como indica el naturalista inglés (Darwin 1871: 32)... / ...tal y como indica el naturalista inglés Darwin (1871: 32).. / “...todo apuntaba en esa dirección” (Autor1; Autor2; Autor3 2018: 15) / “...todo apuntaba en esa dirección" (Autor1 et al. 2018: 15) / Autor et al. (2018) ha explicado que “...todo apuntaba en esa dirección” (15). 
Ello no excluye que se abra una reflexión complementaria, si así se estima oportuno, en nota a pie de página, a 9 puntos, Times New Roman, justificado, interlineado sencillo. Cuando se indique que parte de la cita ha sido omitida se emplearán tres puntos entre corchetes [...]. Si la cita es en lengua distinta a la del artículo, se tratará de buscar su traducción en alguna edición en castellano y se añadirá entre corchetes la cita en la lengua original (en caso de que no se disponga de una traducción, el autor indicará que la misma ha sido elaborada por él mismo mediante la abreviatura a. trad., o bien en una nota a pie de página si todas las traducciones son propias); por ejemplo

"...todo apuntaba a dicha interpretación" ["...All leads us in that direction"] (Autor 2017: 18; 1995: 20) / “...todo apuntaba a dicha interpretación” (a. trad.) [“...All leads us in that direction”] (Autor 1995: 20)

Cuando las citas textuales superen los 4 renglones se colocarán aparte, a 10 puntos, en un párrafo justificado y sangrado en primera lína a $1,25 \mathrm{~cm}$.

Citaciones kantianas

En el caso de obras de Kant, en cuerpo de texto y nota se aludirá a ellas empleando las abreviaturas establecidas por la Kant-Forschungsstelle de Maguncia. Las abreviaturas se hallan publicadas en su página web (http://www.kant.uni-mainz.de/), pestaña 'Kant-Studien', sección 'Hinweise für Autoren'.

\subsection{Apartados}

Los encabezados de los apartados y subapartados se indicarán mediante la siguiente numeración: $1,1.1,1.1 .1 \ldots$ etc., sin cursiva ni negrita, a Times New Roman, 12 puntos. La enumeración de listados empleará los indicativos i), ii), iii), etc. Cada apartado irá separado del anterior por un espacio en blanco.

\subsection{Uso de las comillas, guiones, corchetes y cursiva}

Comillas altas o inglesas (“"): para citas textuales, ej. "todo apuntaba en esa dirección"; para títulos de artículos, capítulos de libro, noticias, posts, entradas en una web, entradas en enciclopedia, título de ponencia..., ej. En el tercer capítulo "La verdad y la mentira" / Así lo demostró en su artículo "La recepción de los colores". 
Comillas simples (' '): para añadir énfasis a una palabra o expresión, ej. Esa 'verdad' era muy relativa.

Corchetes ([ ]): para la traducción de palabras extranjeras, ej. Cuando Heidegger habla de Stimmung [estado de ánimo], está refiriéndose a...

Cursiva: reservada para palabras o expresiones en lengua distinta a la del manuscrito, así como para títulos de libro, revistas, periódicos, películas, páginas web, blogs, congresos..., ej. Así lo describe Kant en la Crítica de la razón pura / La noticia apareció en El país / La revista Evolutionary Anthropology se encargó de la publicación... / Como apunta la autora en su web Ver para creer...

\subsection{Notas a pie}

Los números indicativos de las notas a pie de página (que en ningún caso se colocarán al final del documento, sino al final de cada página) deben encontrarse después de los signos de puntuación.

\subsection{Referencias bibliográficas}

Las referencias bibliográficas completas aparecerán al final de la contribución, en un apartado ad hoc bajo el título Bibliografía o Referencias, según corresponda, por orden alfabético aplicado a los apellidos de los autores. En el caso de que varias publicaciones del mismo autor coincidan en el mismo año, se las distinguirá con letras (1999a, 1999b).

Citas de libros

MORENO, J.: Los retos actuales del darwinismo. ¿Una teoría en crisis?, Madrid, Síntesis, 2008.

DARWIN, C.: The Descent of Man and Selection in Relation to Sex, Londres, John Murray, 1871, 1882 (2 ed.).

: El origen del hombre y la selección en relación al sexo, trad.

Julián Aguirre, Madrid, EDAF, 2006.

Capítulos de libro

KINSBOURNE, M.: "Integrated field theory of consciousness", en MARCEL, A.; BISIACH, E. (eds.): Consciousness in Contemporary Science, Oxford, Oxford University Press, 1988, 35-78. 
ROS VELASCO, J.: "Introduction", en: Feminism. Past, Present, and Future Perspectives, Nueva York, Nova, 2017, 1-16.

Artículos

TINBERGEN, N.: "On aims and methods of Ethology", Zeitschrift für Tierpsychologie 20 (1963) 410-433.

MARTIN, S.: "Recepciones de la despersonalización", Retos 12, 3 (2015) 103-115.

Recursos de internet

LEMOS RODRÍGUEZ, R.: “Conoce los beneficios del aburrimiento”, La mente es maravillosa (Web), 2015,

https://lamenteesmaravillosa.com/conoce-los-beneficios-del-aburrimiento/.

CAMPOS DÍEZ, A.: "Cómo vencer al aburrimiento sin moverse del sofá", El país (online), 2015,

https://elpais.com/elpais/2015/02/19/buenavida/1424345312 592437.html.

FLORES, Y.: “Aburrido. ¿Qué hacer contra el aburrimiento?”, El blog de Yes (Blog), 2017,

http://www.elblogdeyes.com/aburrido-que-hacer-contra-el-aburrimiento/.

ARCHILA, A.: "El aburrimiento", Youtube (Clip de video), 2016, https://www.youtube.com/watch?v=0NXrkHpIFn4.

\section{Revisión}

Cada autor/a revisará detenidamente que de su envío haya sido eliminado cualquier indicio que pudiera denotar su identidad. En el caso de que se aluda a publicaciones propias, se sustituirá todos los datos por la indicación [Datos eliminados para favorecer la anonimidad del envío]. Del mismo modo, se cuidará de que el documento no contenga información sobre la autoría en sus propiedades informáticas.

\section{Envío}

Los trabajos deberán ser enviados a través de la plataforma virtual: 
https://ojs.uv.es/index.php/REK/

Es aconsejable que los autores revisen los artículos publicados previamente para una mejor adaptación a las normas de estilo o que usen la plantilla disponible en la web de la revista.

\section{Instructions for contributors}

The journal publishes papers in Spanish, German, English, and Portuguese, dealing with Kantian philosophy or with issues raised in it. Contributions must be original and should not exceed 25 pages $(80,000$ characters with spaces). Reviews should not exceed 5 pages (16,000 characters with spaces).

\section{Heading}

The text will be headed by title (Times New Roman, 14 points), abstract (max. 100 words, Times New Roman, 10 points) and keywords (max. 5, Times New Roman, 10 points, separated by commas) in both the language in which the work is written and English (if written in Spanish) or Spanish (if written in English, German, or Portuguese).

\section{Style}

\subsection{Body text}

The text will be written in Times New Roman, 12 points, multiple spacing 1,15 , line spacing after 6 points, justified paragraphs, first line intended $(1,25$ $\mathrm{cm}$ ), as long as it is not the paragraph with which the section starts.

\subsection{Quotes}

The textual quotes will appear in the text self, by referring to author and year followed by colon and page number. For example:

...so as pointed out by the British naturalist (Darwin 1871: 32)... / ...as so pointed by the British naturalist Darwin (1871: 32) / “...all leads us to that 
direction" (Autor1; Autor2; Autor3 2018: 15) / “... all leads us to that direction" (Autor1 et al. 2018: 15) / Autor et al. (2018) explained that "all leads us to that direction" (15).

If considered suitable, a further discussion in a footnote is not excluded ( 9 points, Times New Roman, justified, simple space). To indicate that a part of the quoted text has been omitted three points will be used in brackets [...]. If the quote is in a different language, the author should look for a translation, adding the original quote in brackets. If no translation is available, the author will indicate that it has been drawn up by himself by the abbreviation a. trans. or in a footnote if all translations have been made by the author.

"...All leads us in that direction" [“...todo apuntaba a dicha interpretación”] (Autor 2017: 18; 1995: 20) / "...All leads us in that direction" (a. trans.) [“...todo apuntaba a dicha interpretación”] (Autor 1995: 20)

When quotations exceed 4 lines will be placed apart, 10 points, in a justified paragraph and $1,25 \mathrm{~cm}$.

Kantian quotes

The citation of Kantian texts will employ the abbreviations established by the Kant-Forschungsstelle Mainz (see website http://www.kant.uni-mainz.de/, 'Kant-Studien', section 'Hinweise für Autoren').

\subsection{Sub-headings}

The headings of the sections and subsections shall be indicated by the following numbers: 1, 1.1, 1.1.1., etc., without italics nor bold, Times New Roman, 12 points. To enumerate the elements of a list: i), ii), iii), etc. Each sub-heading will be separated from the previous by a space.

\subsection{Quotation marks and italics}

Inverted commas (“"): literary quotes, e.g. "all leds us in that direction"; titles of papers, book chapters, news, posts, communications... e.g. In the third chapter "The truth and the lie" / That was pointed in his paper "Color perception". 
Single quotes (' '): to add emphasis to a word or expression, e.g. This 'truth' is relative.

Brackets ([ ]): to translate words in other language, e.g. Heidegger is talking about the Stimmung [mood]...

Italics: to foreign words and titles of books, journals, diaries, movies, websites, blogs, conferences... e.g. This is what Kant says in his Critique of pure reason / The piece of news published in the New York Times... / The journal Evolutionary Anthropology published... / As the author point in her web Looking for knowledge...

\subsection{Footnotes}

The indicative numbers for footnotes (which in any case will be placed at the end of the document, but at the end of each page) must meet after punctuation.

\subsection{References or Bibliography}

The complete references will be indicated (in alphabetic order of the name of the authors) at the end of the contribution, in a section entitled Bibliography or References. Should different publications of an author be edited in the same year, they will appear with subscript characters (1999a, 1999b).

Books

MORENO, J.: Los retos actuales del darwinismo. ¿Una teoría en crisis?, Madrid, Síntesis, 2008.

DARWIN, C.: The Descent of Man and Selection in Relation to Sex, London, John Murray, 1871, 1882 (2 ed.).

: El origen del hombre y la selección en relación al sexo, trans.

Julián Aguirre, Madrid, EDAF, 2006.

Book chapter

KINSBOURNE, M.: "Integrated field theory of consciousness", in MARCEL, A.; BISIACH, E. (eds.): Consciousness in Contemporary Science, Oxford, Oxford University Press, 1988, 35-78.

ROS VELASCO, J.: "Introduction", in: Feminism. Past, Present, and Future Perspectives, New York, Nova, 2017, 1-16. 
Papers

TINBERGEN, N.: "On aims and methods of Ethology", Zeitschrift für Tierpsychologie 20 (1963) 410-433.

MARTIN, S.: "Recepciones de la despersonalización", Retos 12, 3 (2015) 103-115.

Internet resources

LEMOS RODRÍGUEZ, R.: "Conoce los beneficios del aburrimiento", La mente es maravillosa (Web), 2015,

https:/lamenteesmaravillosa.com/conoce-los-beneficios-del-aburrimiento/.

CAMPOS DÍEZ, A.: "Cómo vencer al aburrimiento sin moverse del sofá", El país (online), 2015,

https://elpais.com/elpais/2015/02/19/buenavida/1424345312 592437.html.

FLORES, Y.: “Aburrido. ¿Qué hacer contra el aburrimiento?”, El blog de Yes (Blog), 2017,

http:/www.elblogdeyes.com/aburrido-que-hacer-contra-el-aburrimiento/.

ARCHILA, A.: "El aburrimiento", Youtube (Videoclip), 2016, https://www.youtube.com/watch?v=0NXrkHpIFn4.

\section{$\underline{\text { 3. Revision }}$}

Each author will make sure that all indication of identity has been removed. In case of quotation of the author's own publications, the reference will be replaced by the sentence "[Reference removed to guarantee anonymous review]". The author will take care that the file does not include personal information within its digital properties.

4. Sending

Contibutions should be uploaded to:

https://ojs.uv.es/index.php/REK/

It is advisable that the authors review the previously published articles or use the provided template to better adaptation to the style rules. 